PNNL-18408, Rev 1

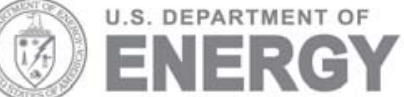

53451-RPT05, Rev 1

Prepared for the U.S. Department of Energy

under Contract DE-AC05-76RL01830

\title{
Characterization of Settler Tank, KW Container and KE Container Sludge Simulants
}

\section{CA Burns}

M Luna

AJ Schmidt

April 2011

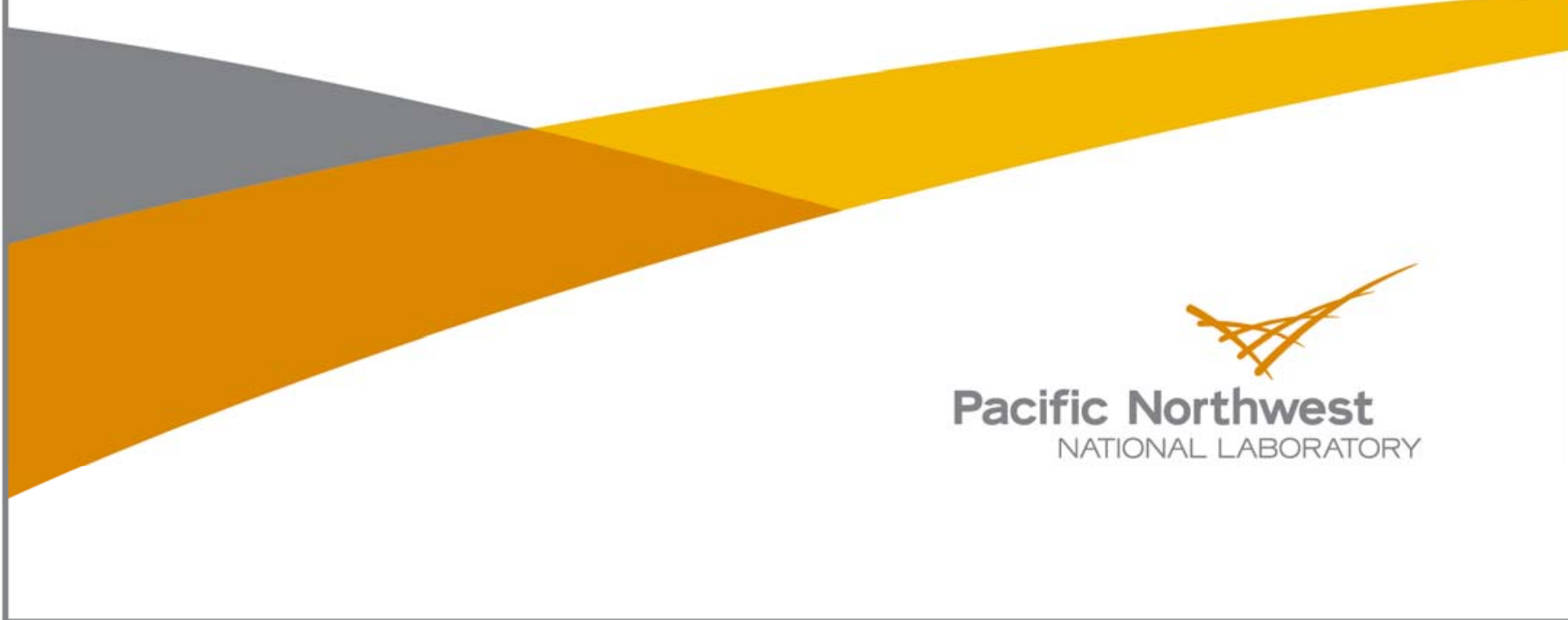




\title{
Characterization of Settler Tank, KW Container and KE Container Sludge Simulants
}

\author{
CA Burns \\ M Luna
}

AJ Schmidt

April 2011

Prepared for

the U.S. Department of Energy

under Contract DE-AC05-76RL01830

Pacific Northwest National Laboratory

Richland, Washington 99352 


\section{Revision History}

\begin{tabular}{|c|c|c|}
\hline Revision & Date & Reason for Revision \\
\hline 0 & $\begin{array}{l}\text { May } \\
2009\end{array}$ & $\begin{array}{l}\text { Initial revision, issued to report the results of simulant } \\
\text { characterization efforts performed on simulants representative of: } \\
\text { - KW Settler sludge [identified as Settler Sludge Simulant (230) in } \\
\text { Table } 7-3 \text { of Burbank, } 2010^{\text {a(a) }} \text { ]. } \\
\text { - KW Container sludge [identified as KW Origin Container Sludge } \\
\text { Simulant }(210,220) \text { in Table } 7-2 \text { of Burbank, 2010]. } \\
\text { The report provides baseline characterization data on simulants being } \\
\text { used by STP for process development and equipment testing, and } \\
\text { provides a high-level comparison of the simulant characteristics to the } \\
\text { targets used to formulate the simulants. }\end{array}$ \\
\hline 1 & $\begin{array}{c}\text { March } \\
2011\end{array}$ & $\begin{array}{l}\text { Revision } 1 \text { was issued to include the results of simulant } \\
\text { characterization efforts performed on simulant representative of: } \\
\text { - KE Container sludge [identified as KE Origin Container Sludge } \\
\text { Simulant }(240,250,260) \text { in Table } 7-1 \text { of Burbank, 2010]. } \\
\text { KE simulant characterization was performed to complete the } \\
\text { characterization of the three base Sludge Treatment Project sludge } \\
\text { simulant recipes. } \\
\text { - No information/data reported in Revision } 0 \text { of the report was } \\
\text { changed in Revision } 1 . \\
\text { - Information for one additional simulant was added throughout the } \\
\text { report; this new information is identified in tables, figures, and } \\
\text { text as "KE Container Sludge Simulant". } \\
\text { - Minor changes were made to formatting and to correct errors in } \\
\text { grammar or punctuation. }\end{array}$ \\
\hline
\end{tabular}

(a) Burbank, DA. 2010. "Sludge Treatment Project,"Sludge Simulant Strategy and Design Basis," PRC-STP-00034, Rev. 1, CH2M Hill, Plateau Remediation Company, Richland, WA. Compositions were originally documented in: GT MacLean. 2008. K Basin Sludge Simulants, Letter Report, From GT MacLean (Fluor Government Group) to R Lokken, August 7, 2008, Fluor Government Group, Richland, WA (See Attachment A). [Note: the information contained within this communication has been captured in Burbank (2010).] 


\begin{abstract}
The Sludge Treatment Project (STP), managed by CH2M Hill Plateau Remediation Company (CHPRC) has specified base formulations for non-radioactive sludge simulants for use in the development and testing of equipment for sludge sampling, retrieval, transport, and processing. In general, the simulant formulations are based on the average or design-basis physical and chemical properties obtained by characterizing sludge samples. The simulants include surrogates for uranium metal, uranium oxides (agglomerates and fine particulate), and the predominant chemical phases (iron and aluminum hydroxides, sand). Specific surrogate components were selected to match the nominal particle-size distribution and particle-density data obtained from sludge sample analysis.

The STP base simulant compositions, designed to represent three primary K Basin sludge streams, are:

1. KE Basin Origin container sludge simulant (KE container simulant), to represent sludge originating in the KE Basin pits and floor that now resides in KW containers 240, 250, and 260

2. KW Basin Origin container sludge simulant (KW container simulant), to represent sludge originating from the K West pit and floors that now resides in KW containers 210 and 220, and

3. Settler sludge simulant, to represent KW settler tank sludge that now resides in KW container 230.

Under contract to CHPRC, Pacific Northwest National Laboratory (PNNL) has performed physical and rheological characterization of simulants, and the results are reported here. Two simulant types were prepared by STP staff at the Maintenance and Storage Facility and received by PNNL in February 2009: Settler Tank Simulant and KW Container Simulant. A third simulant, KE Container Simulant, was received by PNNL in December 2010. The objectives of this simulant characterization effort were to provide baseline characterization data on simulants being used by STP for process development and equipment testing and provide a high-level comparison of the simulant characteristics to the targets used to formulate the simulants.
\end{abstract}





\section{Summary}

The Sludge Treatment Project (STP), managed by CH2M Hill Plateau Remediation Company (CHPRC), has specified base formulations for non-radioactive sludge simulants for use in developing and testing equipment for sludge sampling, retrieval, transport, and processing. The simulant compositions are documented in a memorandum that is included in Appendix $A^{(a)}$ and in Burbank (2010). In general, the simulant formulations are based on the average or design-basis physical and chemical properties obtained through characterization of actual sludge samples. The simulants include surrogates for uranium metal, uranium oxides (agglomerates and fine particulate), and the predominant chemical phases (iron and aluminum hydroxides, sand). Specific surrogate components were selected to match the nominal particle-size distribution (PSD) and particle-density data obtained from sludge sample analysis.

The STP base simulant compositions, designed to represent three primary K Basin sludge streams, are:

1. KE Basin Origin container sludge simulant (KE container simulant), to represent sludge originating in the KE Basin pits and floor that now resides in KW containers 240, 250, and 260

2. KW Basin Origin container sludge simulant (KW container simulant), to represent sludge originating from the K West pit and floors that now resides in KW containers 210 and 220, and

3. Settler sludge simulant, to represent KW settler tank sludge that now resides in KW container 230.

Under contract to CHPRC, Pacific Northwest National Laboratory (PNNL) has performed physical and rheological characterization of simulants, and the results are reported here. Two simulant types were prepared by STP staff at the Maintenance and Storage Facility (MASF) and received by PNNL in February 2009: settler tank simulant, and KW container simulant. A third simulant, KE container simulant, was prepared at MASF by STP staff and received at PNNL in December 2010. To support rheological characterization, the $\mathrm{KW}$ and $\mathrm{KE}$ container simulants were provided as several discrete samples, whole PSD and simulant sieved at $500 \mu \mathrm{m}$. Both fractions were provided for the sieved KW simulant in 2009 but only the $<500 \mu \mathrm{m}$ fraction was received for the more recent KE sieved simulant. Settler sludge simulant only contains particles less than $600 \mu \mathrm{m}$; therefore, size fractionation of this simulant was not required.

The objectives of this simulant characterization effort were:

1) Provide baseline characterization data on simulants being used by STP for process development and equipment testing.

2) Provide a high-level comparison of the simulant characteristics to the targets used to formulate the simulants.

3) Update base simulant formulations as necessary. New data has been, or will be, acquired from characterization of actual sludge samples during the second half of FY 2009 (sludge from KW

(a) GT MacLean. 2008. K Basin Sludge Simulants, Letter Report, From GT MacLean (Fluor Government Group) to R Lokken, August 7, 2008, Fluor Government Group, Richland, WA (See Attachment A). [Note: the information contained within this communication has been captured in Burbank (2010).] 
containers 240, 250, 260, and 220) and in FY 2011 [sludge from settler tanks (KW container 230) and $\mathrm{KW}$ container 210]. If significant discrepancies in properties are found between the simulant and new sludge samples, and these differences are important to the STP equipment testing objectives, then base simulant formulations may be adjusted.

The simulant characterization approach used by PNNL was based on the physical and rheological characterization approach described within the Sampling Analysis Plan (SAP) for sludge in the KW engineered containers (Baker et al .2009). Thus, this characterization work is serving as an opportunity to refine and optimize the sample handling and rheological characterization techniques that are to be used with actual sludge samples. 


\section{S.1 Settler-Sludge-Simulant Characterization}

Table S.1 summarizes the PNNL characterization results obtained from the settler simulant sample (ST-A) provided by STP in February 2009 and compares the results to other simulants and data. The properties and parameters are compared to the values established in Schmidt and Zacher (2007) (Composition and Technical Basis for K Basin settler sludge simulant for Inspection Retrieval and Pump Testing) and incorporated into the MacLean memorandum (Attachment A). ${ }^{\text {(a) }}$ In Schmidt and Zacher (2007), the simulant was formulated based on data (i.e., composition and PSD) from KE and KW canister sludge samples (i.e., predominant source streams to the settler tanks). Settled density was also identified as a key parameter during the simulant development, and an iron hydroxide slurry was added to control this parameter. Targets for shear strength and yield stress were not specified in Schmidt and Zacher (2007); however, the simulant sample prepared in 2007 exhibited a relatively high shear strength relative to actual sludge samples (Plys and Schmidt 2006).

Characterization of settler simulant (ST-A) (Table S.1) demonstrates that it adequately meets most targets established during simulant development. However, the measured shear strength does not bound the maximum values measured for all sludge samples (i.e., including KE Canister sludge samples with particles greater than $250 \mu \mathrm{m}$ ) and is lower than the settler simulant prepared in 2007 (using essentially the same formulation). With granular sludges, shear-strength measurements are highly sensitive to sample history, vessel geometry, and water content. Differences in handling (i.e., higher water content of ST-A) and characterization techniques likely contributed to the differences in the characterization results between settler simulant prepared in 2009 and 2007.

Larger batches of settler simulant and KW container simulant have been prepared by CHPRC and loaded into large-scale mock-up test systems and 55-gal drums at MASF. In these configurations, the CHPRC operators and test engineers have observed very high strengths in the simulant (qualitative observations). These observations are consistent with predictions of the behavior of materials with significant granularity under a lithostatic head (i.e., contribution of fractional forces to shear strength).

The PSD of settler simulant sample ST-A is consistent with the target values established in Schmidt and Zacher (2007). To match the established PSD targets, mass-weighted PSDs of the individual simulant components were summed (values in Table S.1), and PSD measurements of the resulting simulant were not performed in 2007. The PSDs of the individual simulant components used for the ST-A simulant are known based on vendor data, sieving, and PSD measurement performed on individual components. Due to sample size limitations (very small), sub-sampling challenges, and instrument limitations (i.e., use of optical light-scattering technique for samples with complex composition, size, and density), to obtain a representative PSD (by volume), multiple sub-samples need to be analyzed and averaged.

(a) GT MacLean. 2008. K Basin Sludge Simulants, Letter Report, From GT MacLean (Fluor Government Group) to R Lokken, August 7, 2008, Fluor Government Group, Richland, WA (See Attachment A). [Note: the information contained within this communication has been captured in Burbank (2010).] 
Table S.1. Settler Sludge Simulant Characterization Summary and Comparison

\begin{tabular}{|c|c|c|c|c|c|}
\hline \multirow[b]{2}{*}{ Property/Parameter } & \multirow[b]{2}{*}{ Unit } & \multirow{2}{*}{$\begin{array}{l}\text { Settler } \\
\text { Simulant } \\
\text { ST-A } \\
(2-12-09)\end{array}$} & \multirow{2}{*}{$\begin{array}{c}\text { Settler } \\
\text { Simulant }^{(\mathrm{a})} \\
2007\end{array}$} & \multicolumn{2}{|c|}{$\begin{array}{c}\text { Parameters given in Schmidt } \\
\text { and Zacher, 2007, unless } \\
\text { otherwise noted }\end{array}$} \\
\hline & & & & Target & Range \\
\hline U metal/surrogate, dry & $\mathrm{Wt} \%$ & 6.0 & 6.0 & 6.0 & 2.7 to 7.1 \\
\hline U Oxides/surrogate & $\mathrm{Wt} \%$ & 82 & 82 & 82 & 77 to 94 \\
\hline Ave Particle Density ${ }^{(b)}$ & $\mathrm{g} / \mathrm{cm}^{3}$ & 5.9 to $6.0^{(\mathrm{b})}$ & 6.0 to $6.2^{(\mathrm{b})}$ & 6.0 & 4.6 to 9.6 \\
\hline Settled Density & $\mathrm{g} / \mathrm{cm}^{3}$ & 2.4 to 2.5 & 2.7 & 2.7 & 1.9 to 4.0 \\
\hline Volume \% Water & $\%$ & 69 & 67 & 6.7 & 63 to 75 \\
\hline $\begin{array}{l}\text { Shear Strength } \\
\text { Average } \\
\text { High Measurement }\end{array}$ & $\begin{array}{l}\mathrm{Pa} \\
\mathrm{Pa}\end{array}$ & $\begin{array}{c}450 \text { to } 600 \\
1200^{(\mathrm{d})}\end{array}$ & $\begin{array}{c}3650 \pm 700 \\
6920 \pm 230^{(\mathrm{e})}\end{array}$ & $\begin{array}{c}\text { Not } \\
\text { Specified }\end{array}$ & $\begin{array}{l}\sim 280 \pm 110^{(\mathrm{c})} \\
8200 \pm 4000^{(\mathrm{c})}\end{array}$ \\
\hline $\begin{array}{l}\text { Bingham Fits } \\
\text { Yield Stress } \\
\text { Viscosity }\end{array}$ & $\begin{array}{c}\mathrm{Pa} \\
\mathrm{Pa} \cdot \mathrm{sec}\end{array}$ & $\begin{array}{c}6 \text { to } 7 \\
1.9 \text { to } 2.4\end{array}$ & $\begin{array}{l}\text { NM } \\
\text { NM }\end{array}$ & $\begin{array}{c}\text { Not } \\
\text { Specified }\end{array}$ & $\begin{array}{c}5 \text { to } 40^{(\mathrm{f})} \\
\text { Not provided }\end{array}$ \\
\hline Particle Size Distribution & & & & & \\
\hline $\mathrm{D}_{90}(90 \%<)$ & $\mu \mathrm{m}$ & 334 & Calculated from & 350 & 50 to 350 \\
\hline $\mathrm{D}_{50}(50 \%<)$ & $\mu \mathrm{m}$ & 14 & individual & 13 & 6 to 20 \\
\hline $\mathrm{D}_{20}(20 \%<)$ & $\mu \mathrm{m}$ & 5 & components & 2 & $<1$ to 5 \\
\hline
\end{tabular}

$\mathrm{NM}=$ not measured.

(a) Settler simulant prepared and characterized in Schmidt and Zacher (2007).

(b) Calculated from settled density and volume-fraction water measurements.

(c) Plys and Schmidt (2006), Table C-2. $280 \pm 110 \mathrm{~Pa}$ is based on sieved KE Canister sludge samples containing only particles less than at $250 \mu \mathrm{m} .8200 \pm 4000$ Pa measured on sample with whole PSD.

(d) Measured near bottom of sample container.

(e) Measured after sample was transported. Sample may have compacted during transport.

(f) Range in yield stress values for KE and KW canister sludge. Makenas et al. (1997, pp. I-80 to I-82); and Makenas et al. (1998, p F-52, F-53). 


\section{S.2 KW Container Sludge Simulant Characterization}

Table S. 2 summarizes the PNNL characterization results obtained from the KW container simulant samples, KW-A (whole) and KW-B $(<500 \mu \mathrm{m})$, provided by STP in February 2009 and compares the results to targets (MacLean memorandum) and the Sludge Databook Rev. 14 (Schmidt 2009) parameters. The KW container simulant was formulated to represent the full sludge PSD of sludge within engineered containers 210 and 220 (i.e., maximum size, up to $6350 \mu \mathrm{m}[1 / 4 \mathrm{in}$.$] ). Therefore, consistent with the SAP$ for KW containerized sludge (Baker et al. 2009), and to better conform to instrumentation limits/recommendations on particle size, much of the rheological characterization of the KW container sludge simulant was performed on size-segregated simulant (KW-B). Particles greater than $500 \mu \mathrm{m}$ (approximately $25 \mathrm{wt} \%$ of whole sample) were removed by passing the simulant through a sieve. Because of the sieving, characterization results from the KW-B sample $(<500 \mu \mathrm{m})$ are not directly comparable to targets established for the "whole" simulant.

Comparison of the KW container simulant to Sludge Databook, Rev. 14 (Schmidt 2009) parameters (Table S.2) shows that the simulant was formulated based on design-basis values for the KW originating (container 210 and 220) sludge. Because the composition of the safety-basis KW-originating sludge approaches that of settler sludge (and exceeds it with respect to uranium metal); design-basis values were used to provide a distinct mobilization/retrieval challenge (i.e., includes significant concentrations of other components: iron hydroxides, aggregate, sand, aluminum hydroxide vs. a simulant with very high concentration of uranium oxide surrogate, such as cerium oxide).

For most parameters of interest to sludge retrieval/mobilization equipment, the results from laboratory characterization of KW container simulants meet or exceed targets established based on existing characterization data. Relatively high shear-strength values were measured for the KW-B sample (sieved to remove all particles greater than $500 \mu \mathrm{m}$ ). The settled density and volume fraction solids are higher (conservative for mobilization and retrieval) than safety-basis KW originating container sludge. The volume contribution of the coarsest particle-size material $(100$ to $500 \mu \mathrm{m})$.in the PSD appears to be lower than expected 
Table S.2. KW Container Sludge Simulant Characterization Summary and Comparison

\begin{tabular}{|c|c|c|c|c|c|c|}
\hline \multirow[b]{3}{*}{ Property/Parameter } & \multirow[b]{3}{*}{ Unit } & \multicolumn{2}{|c|}{ KW Container Samples ${ }^{(a)}$} & \multicolumn{3}{|c|}{$\begin{array}{l}\text { Parameters from MacLean, }{ }^{(b)} \\
\text { (unless otherwise noted) }\end{array}$} \\
\hline & & \multirow{2}{*}{$\begin{array}{c}<500 \mu \mathrm{m} \\
\mathrm{KW}-\mathrm{B}\end{array}$} & \multirow{2}{*}{$\begin{array}{l}\text { Whole } \\
\text { KW-A }\end{array}$} & \multirow{2}{*}{$\begin{array}{l}\text { Target } \\
\text { Whole }\end{array}$} & \multicolumn{2}{|c|}{$\begin{array}{c}\text { Databook KW } \\
\text { Con } 210 \& 220^{(\mathrm{c})} \\
\end{array}$} \\
\hline & & & & & Design & Safety \\
\hline $\begin{array}{l}\text { Fraction of Whole } \\
\text { Sample Mass }\end{array}$ & $\mathrm{Wt} \%$ & 75 & 100 & 100 & 100 & 100 \\
\hline U metal/surrogate, dry & $\mathrm{Wt} \%$ & $<1(\text { Est })^{(\mathrm{d})}$ & 3.6 & 3.6 & 3.6 & 7.7 \\
\hline $\begin{array}{l}\text { U Oxides/surrogate, } \\
\text { dry }\end{array}$ & $\mathrm{Wt} \%$ & $\sim 40(\text { Est })^{(\mathrm{d})}$ & 35.1 & 35.1 & $\sim 35^{(\mathrm{e})}$ & $58^{(\mathrm{e})}$ \\
\hline Ave Particle Density & $\mathrm{g} / \mathrm{cm}^{3}$ & $4.7^{(\mathrm{f})}$ & $3.7^{(\mathrm{f})}$ & 3.29 & 3.3 & 4.1 \\
\hline Settled Density & $\mathrm{g} / \mathrm{cm}^{3}$ & 2.4 & 2.4 & Not Specified & 1.6 & 1.8 \\
\hline Volume \% Water & $\%$ & 62 & 48 & Not Specified & 74 & 74 \\
\hline \multicolumn{7}{|l|}{ Shear Strength } \\
\hline$<500 \mu \mathrm{m}$ & $\mathrm{Pa}$ & 800 to 2400 & NM & Not Specified & \multicolumn{2}{|c|}{$\sim 500^{(\mathrm{g})}$} \\
\hline High Measurement & $\mathrm{Pa}$ & 5700 & NM & & \multicolumn{2}{|c|}{$8200^{(\mathrm{g})}$} \\
\hline \multicolumn{7}{|l|}{ Bingham Fits } \\
\hline Yield Stress & $\mathrm{Pa}$ & 21 to 27 & NM & Not Specified & \multicolumn{2}{|c|}{1 to $40^{(\mathrm{h})}$} \\
\hline Viscosity & $\mathrm{Pa} \cdot \mathrm{sec}$ & 1.6 to 3.4 & NM & & \multicolumn{2}{|c|}{ Not provided } \\
\hline \multicolumn{7}{|c|}{ Particle-Size Distribution } \\
\hline $\mathrm{D}_{90}(90 \%<)$ & $\mu \mathrm{m}$ & 345 & NM & 2200 & \multicolumn{2}{|c|}{$+/-20 \%$} \\
\hline $\mathrm{D}_{50}(50 \%<)$ & $\mu \mathrm{m}$ & 25 & NM & 27 & \multicolumn{2}{|c|}{$+/-20 \%$} \\
\hline $\mathrm{D}_{10}(10 \%<)$ & $\mu \mathrm{m}$ & 3 & NM & 2 & \multicolumn{2}{|c|}{$+/-20 \%$} \\
\hline
\end{tabular}

$\mathrm{NM}=$ not measured.

(a) See Attachment A. Whole PSD sample (KW-A) and $<500-\mu$ m sample (KW-B).

(b) Simulant composition provided in MacLean memorandum. See Attachment A.

(c) Schmidt (2009), Table 5.2.

(d) Estimated by simulant make-up in Attachment A.

(e) Assumes $\mathrm{U}$ oxides are a ${ }^{1} / 3 \mathrm{UO}_{2}+{ }^{1} / 3 \mathrm{U}_{4} \mathrm{O}_{9}+{ }^{1} / 3 \mathrm{UO}_{3} \cdot 2 \mathrm{H}_{2} \mathrm{O}$ mixture ( $\mathrm{U}$ mole basis mixture).

(f) Calculated from settled density and volume fraction water measurements.

(g) Plys and Schmidt (2006), Table C-2. $500 \mathrm{~Pa}$ is based on sieved sludge samples containing only particles less than at $250 \mu \mathrm{m}$. 8200 Pa measured on sample with whole PSD.

(h) Range in yield stress values for KE floor and KE/ KW canister sludge. Makenas et al. (1996, pp I-14 I-15); Makenas et al. (1997, pp I-80 to I-82); and Makenas et al. (1998), pp F-52, F-53. 


\section{S.3 KE Container Sludge Simulant Characterization}

Table S.3 summarizes the PNNL characterization results obtained from the KE container simulant samples, KE-PNNL-Full (whole) and KE-PNNL-500 $(<500 \mu \mathrm{m})$, provided by STP in December 2010 and compares the results to targets (Burbank (2010) and the Sludge Databook Rev. 14B (Schmidt 2010) parameters. The KE container simulant was formulated to represent the full sludge PSD of sludge within engineered containers 240, 250 and 260 (i.e., maximum size, up to $6350 \mu \mathrm{m}$ [ $1 \frac{1}{4}$ in.]). Therefore, consistent with the SAP for KE containerized sludge (Baker et al. 2009), and to better conform to instrumentation limits/recommendations on particle size, much of the rheological characterization of the KE container sludge simulant was performed on size-segregated simulant (KE-PNNL-500). Particles greater than $500 \mu \mathrm{m}$ (approximately $41 \mathrm{wt} \%$ of whole sample) were removed by passing the simulant through a $500 \mu \mathrm{m}$ sieve. Because of the sieving, characterization results from the KE-PNNL-500 sample $(<500 \mu \mathrm{m})$ are not directly comparable to targets established for the "whole" simulant.

For most parameters of interest to sludge retrieval/mobilization equipment, the results from laboratory characterization of KE container simulants are consistent with the targets established based on existing characterization data. The settled density and volume fraction solids are higher (conservative for mobilization and retrieval) than safety-basis KE originating container sludge. The PSD of the simulant includes a higher volume fraction of fine particulate $(<20 \mu \mathrm{m})$ and is therefore likely to be conservative when used in settling tests. 
Table S.3. KE Container Sludge Simulant Characterization Summary and Comparison

\begin{tabular}{|c|c|c|c|c|c|c|}
\hline \multirow[b]{3}{*}{ Property/Parameter } & \multirow[b]{3}{*}{ Unit } & \multicolumn{2}{|c|}{ KE Container Samples $^{(a)}$} & \multicolumn{3}{|c|}{ KE Values for Comparison } \\
\hline & & \multirow{2}{*}{$\begin{array}{c}(<500 \mu \mathrm{m}) \\
\text { KE-PNNL- } \\
500\end{array}$} & \multirow{2}{*}{$\begin{array}{c}\text { Whole } \\
\text { KE-PNNL-Full }\end{array}$} & \multirow{2}{*}{$\begin{array}{c}\text { Target } \\
\text { Whole, Burbank } \\
2010^{(\mathrm{b})}\end{array}$} & \multicolumn{2}{|c|}{$\begin{array}{l}\text { Databook KE Con } \\
240,250 \& 260^{(c)}\end{array}$} \\
\hline & & & & & Design & Safety \\
\hline Fraction of Whole & $\mathrm{Wt} \%$ & 59 & 100 & 100 & 100 & 100 \\
\hline \multicolumn{7}{|l|}{ Sample Mass } \\
\hline U metal/surrogate, dry & $\mathrm{Wt} \%$ & $<1(\text { Est })^{(\mathrm{d})}$ & 1.2 & 1.2 & 0.92 & 3.5 \\
\hline U Oxides/surrogate, dry & $\mathrm{Wt} \%$ & $\sim 16{\text { (Est })^{(\mathrm{d})}}$ & 16.2 & 16.2 & $\sim 19^{(\mathrm{e})}$ & $50^{(\mathrm{e})}$ \\
\hline Ave Particle Density & $\mathrm{g} / \mathrm{cm}^{3}$ & $3.7^{\mathrm{f})}$ & $3.4^{\mathrm{f})}$ & 3.0 & 2.6 & 3.4 \\
\hline Settled Density & $\mathrm{g} / \mathrm{cm}^{3}$ & 1.9 & 2.0 & Not Specified & 1.4 & 1.6 \\
\hline Volume \% Water & $\%$ & 68 & 56 & Not Specified & 75 & 75 \\
\hline Shear Strength & & & & Not Specified & & \\
\hline $\begin{array}{l}\text { Immersion depth } 16 \\
\mathrm{~mm} \text { (Average) }\end{array}$ & $\mathrm{Pa}$ & $570 \pm 90$ & $1200 \pm 240$ & & \multicolumn{2}{|c|}{$\sim 500^{(\mathrm{g})}$} \\
\hline High Measurement & $\mathrm{Pa}$ & 720 & 1568 & & \multicolumn{2}{|c|}{$8200^{(\mathrm{g})}$} \\
\hline Bingham Fits & & & & Not Specified & & \\
\hline $\begin{array}{l}\text { Yield Stress } \\
\left(20^{\circ} \mathrm{C}\right)\end{array}$ & $\mathrm{Pa}$ & 18 to 42 & NM & & \multicolumn{2}{|c|}{1 to $40^{(\mathrm{h})}$} \\
\hline Viscosity $\left(20^{\circ} \mathrm{C}\right)$ & $\mathrm{Pa} \cdot \mathrm{sec}$ & 12.6 to 15.2 & NM & & \multicolumn{2}{|c|}{ Not provided } \\
\hline \multicolumn{7}{|c|}{ Particle-Size Distribution } \\
\hline $\mathrm{D}_{90}(90 \%<)$ & $\mu \mathrm{m}$ & 47 & NM & $2200+/-20 \%$ & \multicolumn{2}{|c|}{ Not provided } \\
\hline $\mathrm{D}_{50}(50 \%<)$ & $\mu \mathrm{m}$ & 7 & NM & $17+/-20 \%$ & \multicolumn{2}{|c|}{ Not provided } \\
\hline $\mathrm{D}_{10}(10 \%<)$ & $\mu \mathrm{m}$ & 0.6 & NM & $1+/-20 \%$ & \multicolumn{2}{|c|}{ Not provided } \\
\hline
\end{tabular}

$\mathrm{NM}=$ not measured.

(a) See Attachment A. Whole PSD sample (KE-PNNL-Full) and < 500- $\mu$ m sample (KE-PNNL-500).

(b) Burbank (2010) encompasses composition provided in MacLean memorandum. See Attachment A.

(c) Schmidt (2010), Table 5.2.

(d) Estimated by simulant make-up in Attachment A.

(e) Assumes $\mathrm{U}$ oxides are $\mathrm{a}{ }^{1} / 3 \mathrm{UO}_{2}+{ }^{1} / 3 \mathrm{U}_{4} \mathrm{O}_{9}+{ }^{1} / 3 \mathrm{UO}_{3} \cdot 2 \mathrm{H}_{2} \mathrm{O}$ mixture ( $\mathrm{U}$ mole basis mixture).

(f) Calculated from settled density and volume fraction water measurements.

(g) Plys and Schmidt (2006), Table C-2. $500 \mathrm{~Pa}$ is based on sieved sludge samples containing only particles less than at $250 \mu \mathrm{m} .8200 \mathrm{~Pa}$ measured on sample with whole PSD.

(h) Range in yield stress values for KE floor and KE/ KW canister sludge. Makenas et al. (1996, pp I-14 I-15); Makenas et al. (1997, pp I-80 to I-82); and Makenas et al. (1998), pp F-52, F-53. 


\section{Conclusions and Recommendations}

The simulant characterization results provide base data to document and better understand simulant properties and behavior.

Experience gained and lessons learned during the characterization of the simulants (PSD and rheological characterization) are being applied to the characterization of the actual sludge samples collected from containerized sludge.

STP equipment testing activities conducted at MASF (documented in STP project records) have shown that the settler sludge and KW container sludge simulants present appreciable challenges to mobilization and retrieval approaches. However, it is not possible for a single simulant to bound all parameters of interest. For each specific process equipment test, careful consideration of each application must be used to guide the selection of simulants and potential modification to the base simulant formulations. 


\section{References}

Baker RB, JA Pottmeyer, JL Westcott, AJ Schmidt, and TL Welsh. 2009. Quality Assurance Project Plan/Sampling and Analysis Plan for Sludge in the KW Engineered Containers, KBC-33786, Rev. 2, CH2M Hill Plateau Remediation Company, Richland, Washington.

Burbank DA. 2010. Sludge Simulant Strategy and Design Basis, PRC-STP-00034, Rev. 1, CH2M Hill Plateau Remediation Company, Richland, Washington.

Makenas BJ, TL Welsh, RB Baker, DR Hansen, and GR Golcar. 1996. Analysis of Sludge form Hanford K East Basin Floor and Weasel Pit, HNF-SP-1182, Westinghouse Hanford Company, Richland, Washington.

Makenas BJ, TL Welsh, RB Baker, EW Hoppe, AJ Schmidt, J Abrefah, JM Tingey, PR Bredt, and GR Golcar. 1997. Analysis of Sludge from Hanford K East Basin Canisters, HNF-SP-1201, Rev. 0, Westinghouse Hanford Company, Richland, Washington.

Makenas BJ, TL Welsh, RB Baker, GR Golcar, PR Bredt, AJ Schmidt, and JM Tingey. 1998. Analysis of Sludge from Hanford K West Basin Canisters, HNF-1728 Rev. 0, Fluor Hanford, Inc., Richland, Washington.

Plys MG and AJ Schmidt. 2006. Supporting Basis for SNF Project Technical Databook, SNF-7765

Rev. 3, Fluor Hanford, Inc. Richland, Washington.

Schmidt AJ. 2009. Spent Nuclear Fuel Project Technical Databook, HNF-SD-SNF-TI-015, Vol. 2, "Sludge," Rev. 14, Fluor Hanford, Inc. Richland, Washington.

Schmidt AJ. 2010. Spent Nuclear Fuel Project Technical Databook, HNF-SD-SNF-TI-015, Vol. 2, "Sludge," Rev. 14B, CH2M Hill Plateau Remediation Company. Richland, Washington.

Schmidt AJ and AH Zacher. 2007. Composition and Technical Basis for K Basin Settler Sludge Simulant for Inspection, Retrieval and Pump Testing, PNNL-16619, Rev 1., Pacific Northwest National Laboratory, Richland, Washington. 


\section{Acronyms}

$\begin{array}{ll}\text { CHPRC } & \text { CH2M Hill Plateau Remediation Company } \\ \text { LHS } & \text { Left hand side } \\ \text { MASF } & \text { Maintenance and Storage Facility } \\ \text { NIST } & \text { National Institute of Standards and Technology } \\ \text { PNNL } & \text { Pacific Northwest National Laboratory } \\ \text { PSD } & \text { particle-size distribution } \\ \text { RHS } & \text { right hand side } \\ \text { SAP } & \text { Sampling Analysis Plan } \\ \text { STDEV } & \text { standard deviation } \\ \text { STP } & \text { Sludge Treatment Project }\end{array}$





\section{Contents}

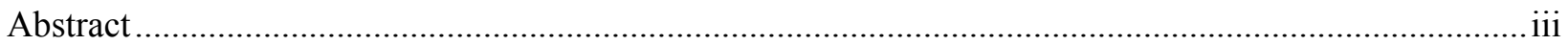

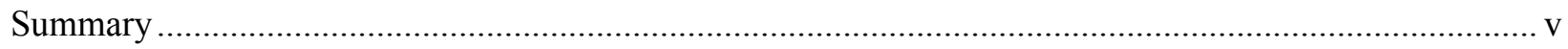

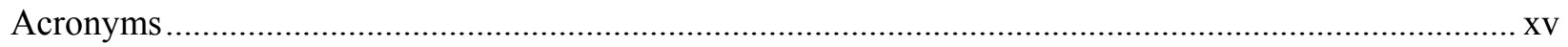

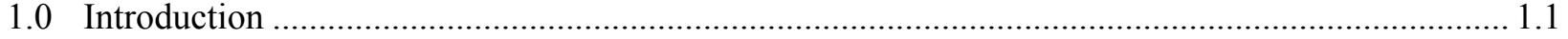

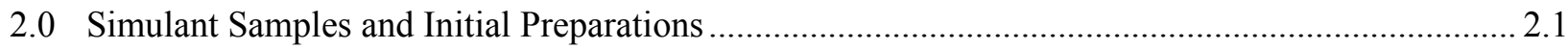

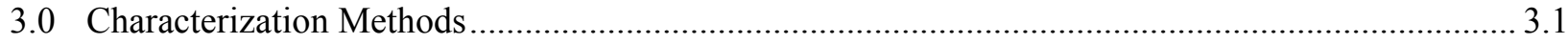

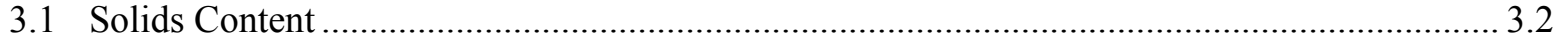

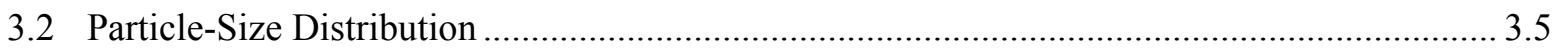

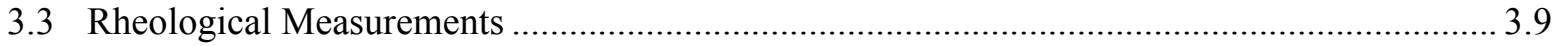

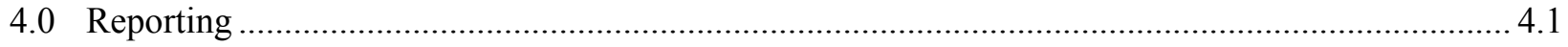

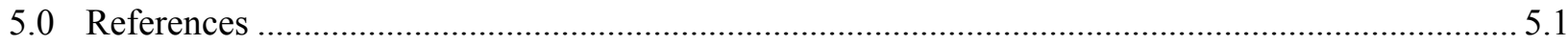

Appendix A: Simulant Material Provided to Pacific Northwest National Laboratory .......................... A.1

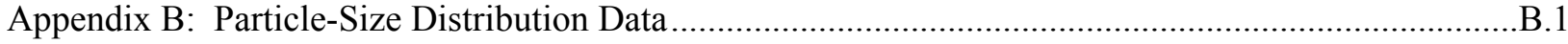

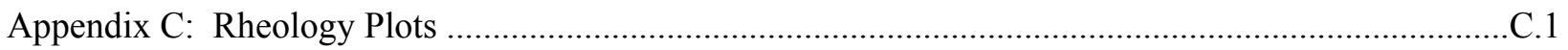




\section{Figures}

Figure 3.1. Graphical Depiction of Approach to Simulant Characterization

Figure 3.2. Average Cumulative Volume \% Undersize Plot After Sonication as a Function of Particle

Size for Settler, KW-B $(<500 \mu \mathrm{m})$, KE-PNNL-500 $(<500 \mu \mathrm{m}$, wet) and KE-PNNL-Full, (whole simulant, dry sieved $<500 \mu \mathrm{m})$ Simulants

Figure 3.3. Average Cumulative Volume \% Undersize Plot Measured at 1-min Recirculation Time of

KE Origin Samples KW240-SCC (TI010), KW250-SCC (TI011), and KW260-SCC (TI012) and

KW Origin Sample from KW220-SCC (data taken from Fiskum et al. 2009).

Figure 3.4. Percent in Range After Sonication, as a Function of Particle Size in Microns for a) Blue Bars, KE-PNNL-500, <500 $\mu$ m Simulant, b) Red Bars, Settler Simulant and c) Black Bars KW-B

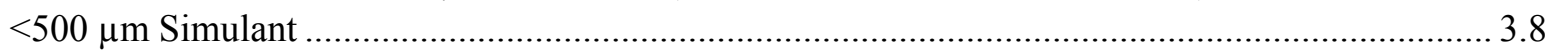

Figure 3.5. Typical Stress-Versus-Time Profile for a Shear Vane at Constant Shear Rate .................. 3.10

Figure 3.6. Shear Stress Versus Shear Rate of Settler Simulant ....................................................... 3.16

Figure 3.7. Viscosity Versus Shear Rate Obtained for the Settler Simulant shown in Figure 3.6........ 3.16

\section{Tables}

Table 1.1. Settler Tank, KW and KE Container Sludge Simulant Compositions.................................. 1.2

Table 2.1. Simulant Received for Characterization ............................................................................ 2.2

Table 3.1. Summary of Simulant Characterization Measurements and Calculations .............................. 3.3

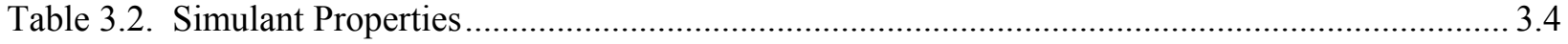

Table 3.3. Particle-Size Analysis of K Basin Simulants After Sonication ............................................. 3.6

Table 3.4. Particle-Size Analysis of K Basin Sludge at 1 Minute Recirculation ..................................... 3.6

Table 3.5. Sieve Analysis of KW-B(P500) and KE-PNNL-Full ....................................................... 3.8

Table 3.6. Simulant Shear-Strength Measurements ............................................................................ 3.13

Table 3.7. Shear Strengths of Actual Sludge Samples......................................................................... 3.14

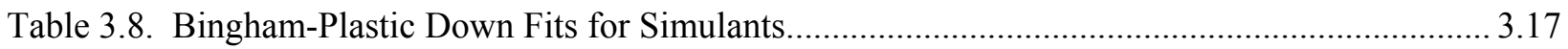

Table 3.9. Bingham-Plastic Fits for Actual Sludge Samples from Containers 240, 250 and 260 (taken

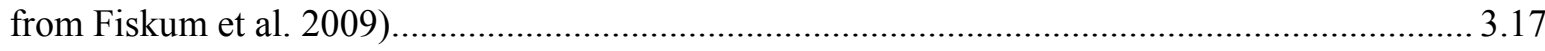




\subsection{Introduction}

The Sludge Treatment Project (STP), managed by CH2M Hill Plateau Remediation Company (CHPRC), has specified base formulations for non-radioactive sludge simulants to use in developing and testing equipment for sludge sampling, retrieval, transport, and processing. Under contract to CHPRC, Pacific Northwest National Laboratory (PNNL) has performed physical and rheological characterization of simulants, and the results are reported here.

The STP base simulant compositions are designed to represent three primary K Basin sludge streams and are documented in Burbank (2010) and a memorandum ${ }^{(a)}$ (MacLean 2008) that is included in Appendix A.

The simulant formulations are:

1. KE Basin Origin container sludge simulant (KE container simulant), to represent sludge originating in the KE Basin pits and floor that now resides in KW containers 240, 250, and 260

2. KW Basin Origin container sludge simulant ( $\mathrm{KW}$ container simulant), to represent sludge originating from the K West pit and floors that now resides in KW containers 210 and 220

3. Settler sludge simulant, to represent $\mathrm{KW}$ settler tank sludge that now resides in $\mathrm{KW}$ container 230.

The first two formulations are similar; however, the KW sludge in containers 210 and 220 is expected to exhibit a higher uranium content (metal and oxide) than the KE Basin originating sludge contained within containers 240, 250, and 260. For equipment testing, the STP initially elected to use the more aggressive KW container simulant to conservatively represent both the KW and KE Basin container sludge. Therefore, for simulant characterization provided in Revision 0 of this report (published in March 2009), only the latter two of the base simulant types (KW container and settler tank simulant) were characterized. In subsequent decisions, equipment testing with KE Container simulant was recommended, and KE container simulant was prepared and shipped to PNNL for characterization. In March 2011 the KE container simulant characterization was added to this report and constitutes the basis for the first revision (Revision 1) of this report.

In addition to the summary formulation provided in the MacLean memorandum (Appendix A), a more detailed description of the technical basis for the settler tank simulant is provided in Schmidt and Zacher (2007). This simulant was formulated based on examination of design- and safety-basis mixtures of KE and KW Canister sludge samples (i.e., the predominant source stream to the settler tanks). The $\mathrm{KW}$ container simulant formulation is based on the average- or design-basis physical and chemical properties of the source streams that make up the sludge in containers 210 and 220 (source streams make-up described in the Sludge Technical Databook [Schmidt 2009]).

(a) GT MacLean. 2008. K Basin Sludge Simulants. Letter Report from GT MacLean (Fluor Government Group) to R Lokken, August 7, 2008, Fluor Government Group, Richland, Washington. [Note: the information contained within this communication has been captured in Burbank (2010).] 
The simulants include surrogates for uranium metal, uranium oxides (agglomerates and fine particulate), and the predominant chemical phases (iron and aluminum hydroxides, sand). Specific surrogate components were selected to match the nominal particle-size distribution (PSD) and particle density data obtained from sludge sample analysis. Table 1.1 provides a summary of the simulant compositions. Additional details on the simulant make-up are provided in Appendix A.

Table 1.1. Settler Tank, KW and KE Container Sludge Simulant Compositions

\begin{tabular}{|c|c|c|c|c|}
\hline \multirow[b]{2}{*}{$\begin{array}{c}\text { Sludge Component } \\
\text { Represented }\end{array}$} & \multirow[b]{2}{*}{$\begin{array}{c}\text { Simulant } \\
\text { Component } \\
\text { Used }\end{array}$} & \multicolumn{3}{|c|}{ Simulant (Dry Basis) } \\
\hline & & $\begin{array}{c}\text { Settler Tank, } \\
\mathrm{Wt}^{\mathrm{o}} \%\end{array}$ & $\begin{array}{c}\mathrm{KW} \\
\text { Container, } \\
\mathrm{Wt} \% \\
\end{array}$ & $\begin{array}{c}\mathrm{KE} \\
\text { Container, } \\
\mathrm{Wt} \% \\
\end{array}$ \\
\hline Uranium metal & $\begin{array}{l}\text { Tungsten } \\
\text { particles }\end{array}$ & 6 & 3.6 & 1.2 \\
\hline $\begin{array}{l}\text { Uranium oxide } \\
\text { agglomerates }\end{array}$ & Steel grit & 14 & 4.2 & 4.1 \\
\hline $\begin{array}{l}\text { Uranium Oxide } \\
\text { fine particles }\end{array}$ & Cerium oxide & 68 & 30.9 & 12.1 \\
\hline $\begin{array}{l}\text { Aluminum } \\
\text { hydroxides and } \\
\text { blow sand }\end{array}$ & Flyash & 11 & 0 & 0 \\
\hline $\begin{array}{l}\text { Non U larger } \\
\text { particles }\end{array}$ & $\begin{array}{l}\text { Aggregate } \\
\text { (rocks) }\end{array}$ & 0 & 16.9 & 14.3 \\
\hline Blow sand & Sand & 0 & 14.7 & 24.1 \\
\hline \multirow[t]{2}{*}{ Iron Phases } & $\begin{array}{l}\text { Iron hydroxide } \\
\text { (added as a } \\
\text { slurry) }\end{array}$ & 1 & 0 & 0 \\
\hline & $\begin{array}{l}\text { Iron oxide } \\
\text { hydroxide }\end{array}$ & 0 & 21.9 & 32.1 \\
\hline Aluminum Phases & $\begin{array}{l}\text { Gibbsite, } \\
\mathrm{Al}(\mathrm{OH})_{3}\end{array}$ & 0 & 7.8 & 12.1 \\
\hline Total & & $100 \%$ & $100 \%$ & $100 \%$ \\
\hline
\end{tabular}

Setter tank sludge is expected to exhibit a much higher uranium total concentration than the KE/KW container sludge, and as shown in Table 1.1, the compositions of these simulants are very different. Also, while the KE/KW container simulants contain particles up to $6350 \mu \mathrm{m}$, the settler sludge simulant only contains particles less than $600 \mu \mathrm{m}$. Therefore, these simulants represent distinct challenges for the development and testing of sludge handling equipment.

To support design and testing goals of the STP, the physical properties and rheology of the KW containerized sludge, settler sludge, and the KE containerized sludge simulants have been characterized. This report outlines the approach that was used to characterize these simulants and documents the results of the characterization efforts. The simulant characterization approach used by PNNL was based on the physical and rheological characterization approach described within the Sampling Analysis Plan (SAP) for sludge in the KW engineered containers (Baker et al. 2009). Thus, this characterization work also 
serves as an opportunity to refine and optimize the sample handling and rheological characterization techniques that will be used with actual sludge samples.

Subsequent to the release of Revision 0 of this report, new data were acquired from characterization of actual sludge samples during 2009 from KW containers 240, 250, 260 and 220 (Fiskum et. al. 2009). A summary of some of the key results obtained for rheological properties and particle size distribution data has been included in the report in the appropriate section, for comparison purposes only. The STP project has performed a comprehensive comparison of the characteristics and properties of the simulants and the available new characterization data from actual sludge samples (Johnson 2010). As actual characterization data continue to be gathered in 2011 from KW containers 210 and 230, STP will perform additional comparisons to demonstrate the base simulants meet the STP equipment testing objectives, and modify simulant compositions if warranted. 


\subsection{Simulant Samples and Initial Preparations}

Simulants were prepared by STP staff at the Maintenance and Storage Facility (MASF). Each simulant component was extracted from the vendor-supplied container with a small shovel or spatula, weighed, and then added to a sample bottle. All weight measurements were performed to the nearest 0.1 gram, using a calibrated balance for the settler simulant and the KW container simulant and to the nearest 0.01 gram for the KE container simulant..

For the settler sludge simulant, $\sim 600 \mathrm{~g}$ of the dry simulant components were provided in a single container. Iron hydroxide slurry, $13 \mathrm{wt} \% \mathrm{Fe}(\mathrm{OH})_{3}$ in water (Noah Technologies Corporation), was provided in a separate container with instructions on the quantity to add to complete the simulant.

STP staff prepared two equal 600 -g batches of KW container sludge simulant. One batch was then subjected to dry sieving (through a \#35 [500 micron] sieve using mechanical agitation for approximately 15 minutes) to create the "fine" and "coarse" KW container simulant fractions. These two sub-fractions were placed into separate bottles.

STP staff prepared two batches f KE container sludge simulant of differing masses (1000 and 3000 grams, respectively). The larger batch was then subjected to dry sieving (through a \#35 [500 micron] sieve using mechanical agitation for approximately 70 minutes) to separate the "fine" and "coarse" KE container simulant fractions. The "fine" sub-fraction was placed in an airtight bag and delivered to PNNL for characterization along with the 1000 gram whole simulant batch.

The simulants (Table 2.1) were received by PNNL on February 12, 2009, and December 6, 2010 under a chain of custody (included in Attachment A). At PNNL, the simulant components were mixed, an excess of water was added, and they were allowed to settle for 24 hours. After this settling period was complete, excess water was decanted from the top of the settled solids. This process of mixing, settling (for 24-hours), and decanting excess water was repeated two more times. To avoid loss of fine particles in the mixed simulant slurry as a result of repeated decanting operations, any solid particles removed with the decant liquid were recovered and returned to the simulant test mixture. Because of the large range in particle sizes and densities of the individual sludge components, dispersions of these materials may be subject to significant size and density segregation. Dilute suspensions of the slurry are likely to yield stratification of simulant components based on the overall particle/aggregate settling velocities. However, well-mixed thickened sludge simulant has sufficient shear strength to uniformly suspend dense particles, and concentration-hindered particle settling also limits the degree of component segregation. For this reason, sub-sampling the settled and thickened slurry provides the most representative sub-sample of complex .mixtures relative to sampling dilute suspensions.

This process of dry weighing and combining components before adding water is consistent with the manner in which large batches of simulant are prepared by STP during testing at MASF; however, due to scale differences, the process may have some inherent differences, particularly in the area of hydration of the solids. 
Table 2.1. Simulant Received for Characterization

\begin{tabular}{|c|c|c|}
\hline $\begin{array}{c}\text { Sample } \\
\text { Identification }\end{array}$ & $\begin{array}{l}\text { Quantity } \\
\text { (Dry } \\
\text { Basis) }\end{array}$ & Description \\
\hline ST-A ${ }^{(a)}$ & $600 \mathrm{~g}$ & $\begin{array}{l}\text { KW Settler Simulant (note PNNL combined dry } \\
\mathrm{Fe}(\mathrm{OH})_{3} \text { slurry with dry components) }\end{array}$ \\
\hline $\mathrm{KW}-\mathrm{A}^{(\mathrm{a})}$ & $600 \mathrm{~g}$ & KW Container Simulant, whole PSD \\
\hline KW-B (M500) $)^{(\mathrm{a})}$ & $449.2 \mathrm{~g}$ & $\begin{array}{l}\text { Size fractionated KW Container Simulant, }<500 \mu \mathrm{m} \\
\text { (Note: unless otherwise noted, KW-B (M500) is } \\
\text { referred to as KW-B in this report) }\end{array}$ \\
\hline KW-B (P500) $)^{(\mathrm{a})}$ & $148.8 \mathrm{~g}$ & $\begin{array}{l}\text { Size fractionated KW Container Simulant, }-6350 \text {, } \\
+500 \mu \mathrm{m}\end{array}$ \\
\hline KE-PNNL-Full ${ }^{(\mathrm{b})}$ & $1054.9 \mathrm{~g}$ & KE Container Simulant, whole PSD \\
\hline KE-PNNL-500 ${ }^{(b)}$ & $1878 \mathrm{~g}$ & Size fractionated KE Container Simulant, $<500 \mu \mathrm{m}$ \\
\hline \multicolumn{3}{|c|}{ Received February 2009} \\
\hline
\end{tabular}




\subsection{Characterization Methods}

A graphical depiction of how the simulant samples were handled and the approach for simulant characterization used at PNNL are given in Figure 3.1. The KW container simulant was formulated to represent the full sludge PSD (i.e., maximum size, up to $6350 \mu \mathrm{m}[1 / 4 \mathrm{in}$.]). Therefore, consistent with the SAP for KW containerized sludge (Baker 2009), and to better conform to instrumentation limits/recommendations on particle size, as shown in Figure 3.1, much of the rheological characterization of the KW container sludge simulant was performed on size-segregated simulant (KW-B). Particles greater than $500 \mu \mathrm{m}$ (approximately $25 \mathrm{wt} \%$ of whole sample), were removed by passing the simulant through a sieve. The KE container sludge simulant characterized in 2010 was characterized in the same manner as the KW container sludge simulant in 2009.

The physical and rheological properties of the simulants were determined according to PNNL technical procedure RPL-COLLOID-02, Rev. 1, "Measurement of Physical and Rheological Properties of Solutions, Slurries, and Sludges." The simulants prepared as described in the preceding paragraphs were to be tested to determine the physical properties outlined in Table 3.1. The physical and rheological properties measured include settled density, solids content (both volume and weight fraction), settling rate, PSD, viscosity as a function of shear rate, and shear strength. The average particle density of the simulants was calculated from the simulant composition and particle density of the individual simulant components. It was observed that the FeOOH from Shepherd used in the formulations of both the KW and the KE container sludge simulants was treated differently between the two characterization studies. In 2010 the inherent moisture content of the $\mathrm{FeOOH}$ was accounted for and the mass used was adjusted to reflect the wt \% FeOOH targeted, where as in 2009 it was not. (Note: the source supply of FeOOH at MASF may have adsorbed moisture during the 20-month storage time between preparation of the KE and KW container simulants.) For the calculated average particle density the of KE container sludge simulant, a range has been reported in Table 3.2. This range reflects the particle density provided by the vendor for the FeOOH of $2.4 \mathrm{~g} / \mathrm{cc}-3.6 \mathrm{~g} / \mathrm{cc}$ on the MSDS. In 2009 a value of $2.85 \mathrm{~g} / \mathrm{cc}$ was used for the calculated average particle density of the KW container sludge simulant using the same batch of $\mathrm{FeOOH}$. Due to the complexities involved in sieving complex mixtures and the added difficulty associated with the water content of the $\mathrm{FeOOH}$ when combined with the other simulant components, the average particle density of the sieved simulants is not given in Table 3.2. Sieving difficulties are further highlighted by the observation that the calculated yield based on particle size data and the observed yield differed significantly for the sieved fractions for both the KW and KE container sludge simulants. It should be noted that due to difficulties in measuring the shear stress vs. shear rate, the proposed dilutions outlined in Table 3.1 were not attempted.

For the determination of settled density, settling rate, and volume fraction of both the water and solids, duplicate aliquots of the simulants were transferred into $100-\mathrm{mL}$ graduated cylinders, and the sediment volume was monitored as a function of time. The sediment volume is the volume from the bottom of the suspension column to the interface between the clear supernatant and the cloudy suspension. In 2010, for the characterization of the KE container sludge simulant, a 40-mL graduated glass centrifuge tube was substituted in place of a graduated cylinder. This is consistent with the method used presently in the hot cells when characterizing actual sludge material. 


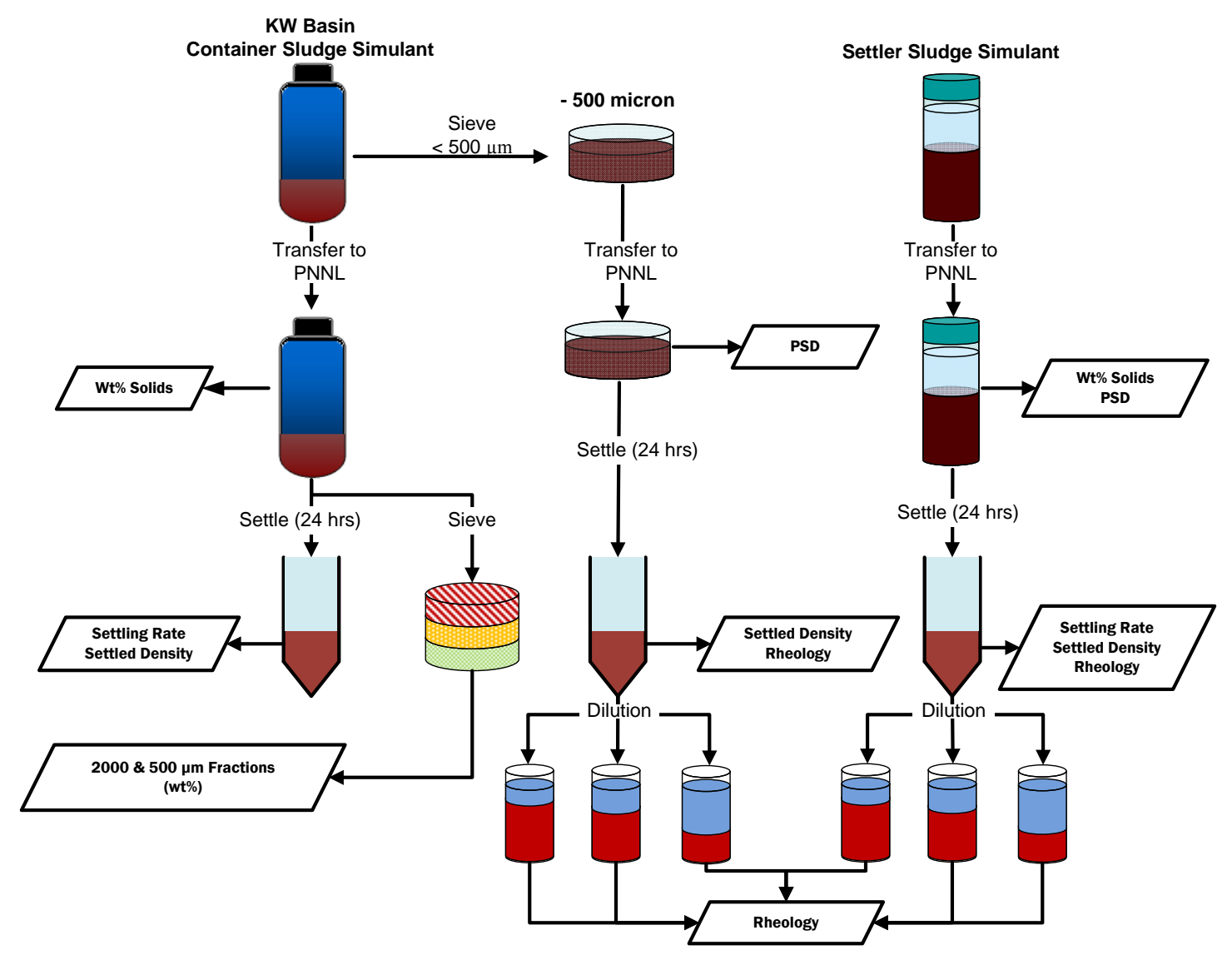

Figure 3.1. Graphical Depiction of Approach to Simulant Characterization

Under the force of gravity, the solids in the suspension sink to the bottom of the cylinder, forming a sludge layer and a clear supernatant layer. The final sediment-bed volume is measured after no significant change in the height of this sludge layer is observed over 4 hours or after 24 hours, whichever comes first. The volume percent settled solids is then determined by dividing the final sediment bed volume by the total volume of the slurry. The settling rate was determined on the dewatered simulant used for all tests outlined in Table 3.1; the settling rate was not measured for the KE container simulant.

\subsection{Solids Content}

The solids content was analyzed with a gravimetric method after oven drying at $105^{\circ} \mathrm{C}$. The procedure for using this method is PNNL Technical Procedure RPL-COLLOID-02, Rev. 1 (Daniel 2007).

The solids content of a sample is the mass of the dried sample divided by the original mass of the settled sample. 
Table 3.1. Summary of Simulant Characterization Measurements and Calculations

\begin{tabular}{|c|c|}
\hline Property/Parameter & Measurement/Calculation Approach \\
\hline Settled Density & $\begin{array}{l}\text { Prep simulant with excess water; allow sludge to settle for } 24 \mathrm{hr} \text {; } \\
\text { measure volume and mass. }\end{array}$ \\
\hline $\begin{array}{l}\text { Wt } \% \text { Total Solids } \\
\text { (in settled sludge) }\end{array}$ & $\begin{array}{l}\text { Dry aliquot (known mass and volume) of as-settled sludge at } 105^{\circ} \mathrm{C} \text {, } \\
\text { measure mass, and record dry bulk volume. }\end{array}$ \\
\hline $\begin{array}{l}\text { Volume Fraction Water } \\
\text { (in settled sludge) }\end{array}$ & $\begin{array}{l}\text { Calculated from settled density and wt } \% \text { solids. Assumption: all } \\
\text { mass loss during drying at } 105^{\circ} \mathrm{C} \text { is from loss of water. }\end{array}$ \\
\hline $\begin{array}{l}\text { Volume Fraction Solids } \\
\text { (in settled sludge) }\end{array}$ & Calculated from volume fraction water. \\
\hline Settling Rate & $\begin{array}{l}\text { Graduated cylinder and stop watch. } \\
\text { Based on agreement with STP, settling rate measurements for the } \\
\text { KE simulant were not included in the scope of this work. }\end{array}$ \\
\hline & Calculated from wt $\%$ solids and vol fraction solids. \\
\hline Average Particle Density & $\begin{array}{l}\text { Calculated from vendor/handbook data on simulant components and } \\
\text { simulant make up. }\end{array}$ \\
\hline \multirow{3}{*}{ Particle-Size Distribution } & Calculated from vendor data on components and simulant make up \\
\hline & $<500 \mu \mathrm{m}^{(\mathrm{a})}$ _-Particle size analyzer. \\
\hline & $\begin{array}{l}\text { Sieve }>500-\mu \mathrm{m} \text { sample using the following: Sieves } 4000 \mu \mathrm{m} \text {, } \\
2000 \mu \mathrm{m} \text {, and } 500 \mu \mathrm{m} \text { - dry mass of resulting three fractions. }\end{array}$ \\
\hline \multirow{3}{*}{$\begin{array}{l}\text { Viscosity vs Shear Rate, Shear } \\
\text { Stress vs. Shear Rate } \\
\text { (Rheograms) }\end{array}$} & $<500 \mu \mathrm{m}$ fraction ${ }^{(a)}$ \\
\hline & $\begin{array}{l}\text { Concentrations: as settled, } 75 \%, 50 \% \text {, and } 25 \% \text { volume ratio of as- } \\
\text { settled + water. }\end{array}$ \\
\hline & Rheology of each concentration was measured at $72^{\circ} \mathrm{F}$. \\
\hline Shear Strength & $\begin{array}{l}<500 \mu \mathrm{m} \text { fraction }{ }^{(\mathrm{a})} \text { : } \\
\text { Settled sludge } 24,48 \text { - to } 91 \text {-hour gel time, vane rheometer. }\end{array}$ \\
\hline
\end{tabular}

(a) Note: for settler sludge simulant, all particles are $<600 \mu \mathrm{m}$. Therefore, for these analyses, settler simulant will not be size fractionated.

A summary of the characterization data obtained is given Table 3.2. 
Table 3.2. Simulant Properties

\begin{tabular}{|c|c|c|c|c|c|c|}
\hline Simulant & $\begin{array}{c}\text { ST-A } \\
\text { (settler) }\end{array}$ & $\begin{array}{c}\mathrm{KW}-\mathrm{B} \\
<500 \mu \mathrm{m}\end{array}$ & $\begin{array}{c}\mathrm{KW}-\mathrm{A} \\
\text { (complete KW) }\end{array}$ & $\begin{array}{l}\text { KE-PNNL-Full } \\
\text { (complete KE) }\end{array}$ & $\begin{array}{l}\text { KE-PNNL-500 } \\
(<500 \mu \mathrm{m})\end{array}$ & Unit \\
\hline \multicolumn{7}{|l|}{ Property } \\
\hline Average Particle Density ${ }^{(a)}$ & 6.00 & & 3.56 & $2.82-3.25$ & & $\mathrm{~g} / \mathrm{cm}^{3}$ \\
\hline Average Particle Density ${ }^{(b)}$ & 5.91 & nd & 3.74 & 3.36 & 3.69 & $\mathrm{~g} / \mathrm{cm}^{3}$ \\
\hline $\begin{array}{l}\text { Settled sludge density }{ }^{(\mathrm{e})} \text {, } \\
\text { ST-A }^{(\mathrm{f})}\end{array}$ & 2.52 & insufficient sample & $2.41 \pm 0.01$ & $2.03 \pm 0.05$ & $1.87 \pm 0.03$ & $\mathrm{~g} / \mathrm{cm}^{3}$ \\
\hline Settled sludge density ${ }^{(\mathrm{g})}$ & $2.42 \pm 0.03$ & $2.38 \pm 0.05$ & & & & $\mathrm{~g} / \mathrm{cm}^{3}$ \\
\hline Settling rate, First 24 hours & 0.17 & 0.04 & 0.09 & NM & NM & $\mathrm{mL} / \mathrm{hr}$ \\
\hline $\mathrm{Wt} \%$ water $^{(\mathrm{b}, \mathrm{e})}$ & $27.40 \pm 0.43$ & $25.51 \pm 0.16$ & $20.05 \pm 0.82$ & $27.70 \pm 0.81$ & $36.21 \pm 0.01$ & Percent \\
\hline Volume fraction water ${ }^{(b, e)}$ & 69.07 & 61.59 & 48.15 & 56.30 & 67.69 & Percent \\
\hline Shear strength ${ }^{(b, c)}$ & & & NM & & & \\
\hline $\begin{array}{l}\text { Mixed, } 21 \text { h gel time, } \\
\text { immersion depth } 1.6 \mathrm{~cm}^{\text {(d) }}\end{array}$ & $491 \pm 36$ & $1719 \pm 580$ & & & & Pascal \\
\hline $\begin{array}{l}\text { Mixed, } 21 \mathrm{~h} \text { gel time, } \\
\text { immersion depth } 3.2 \mathrm{~cm}\end{array}$ & 627 & 1597 & & & & Pascal \\
\hline $\begin{array}{l}\text { Mixed, } \sim 48 \text { h gel time, } \\
\text { immersion depth } 1.6 \mathrm{~cm}^{(\mathrm{h})}\end{array}$ & 612 & $986 \pm 266$ & & $1198 \pm 236$ & $565 \pm 91$ & Pascal \\
\hline $\begin{array}{l}\text { Mixed, } 48 \text { h gel time, } \\
\text { immersion depth } 3.2 \mathrm{~cm}^{(\mathrm{h})}\end{array}$ & & & & $1570 \pm 236$ & $675 \pm 74$ & Pascal \\
\hline $\begin{array}{l}\text { Mixed, } 91 \mathrm{~h} \text { gel time, } \\
\text { immersion depth } 1.6 \mathrm{~cm}\end{array}$ & 604 & $1519 \pm 34$ & & & & Pascal \\
\hline $\begin{array}{l}\text { Mixed, } 91 \mathrm{~h} \text { gel time, } \\
\text { immersion depth } 3.2 \mathrm{~cm}\end{array}$ & 1214 & 1495 & & & & Pascal \\
\hline $\begin{array}{l}\text { NM Not measured. } \\
\text { (a) Calculated based on ve } \\
\text { (b) Based on measuremen } \\
\text { (c) Performed with Haake } \\
\text { VT550, } 1.6 \mathrm{~cm} \text { diamet } \\
\text { (d) Mean } \pm \text { STDEV of } 2( \\
\text { (e) Mean } \pm \text { STDEV of } 2 \mathrm{n} \\
\text { (f) Measurement (1) made } \\
\text { (g) Duplicates measured o } \\
\text { measured several times } \\
\text { (h) Mean } \pm \text { STDEV of } 8 \mathrm{n} \\
\text { for KE simulant. }\end{array}$ & $\begin{array}{l}\text { nd not determin } \\
\text { dor-provided dat } \\
\text { performed on sir } \\
\text { RS } 600,1.6 \mathrm{~cm} \text { c } \\
\text { by } 1.6 \mathrm{~cm} \text { heigh } \\
\text { for ST-A, } 21 \mathrm{hr} \text { ) } \\
\text { asurements. } \\
\text { n unused simula } \\
\text { sample used for } \\
\text { asurements at im }\end{array}$ & $\begin{array}{l}\text { ed } \\
\text { nulant prepared in labor } \\
\text { liameter by } 1.6 \mathrm{~cm} \text { heigl } \\
\text { shear vane for KE sim } \\
\text { measurements. } \\
\text { ht. } \\
\text { Rheology, } \mathrm{KW}-\mathrm{B} \text { measu } \\
\text { mersion depth of } 1.6 \mathrm{~cm}\end{array}$ & $\begin{array}{l}\text { tory. } \\
\text { shear vane for ST- } \\
\text { lant. Samples were } \\
\text { ed on Rheology san } \\
\text { and Mean } \pm \text { STDE }\end{array}$ & $\begin{array}{l}\text { KW-B and KW-A } \\
\text { nixed and measured } \\
\text { ple only. Note: thes } \\
\text { of } 7 \text { measurements }\end{array}$ & $\begin{array}{l}\text { Performed with } \mathrm{H} \\
\text { wice. } \\
\text { samples have been } \\
\text { immersion depth }\end{array}$ & ixed and \\
\hline
\end{tabular}




\subsection{Particle-Size Distribution}

The PSD of the "fines" $(<500 \mu \mathrm{m})$ fraction of the KW and KE container simulants and the "whole" settler simulant (maximum particle size $\sim 600 \mu \mathrm{m}$ ) were measured using laser diffraction technology (Table 3.3, Figure 3.2, and Figure 3.4). A Malvern Mastersizer 2000 equipped with either a Hydro S (KW and settler simulant) or a Hydro G (for the KE container simulant samples) dispersion unit was used to analyze samples, and software for the particle size analyzer calculates the PSD (i.e., fractional volume contribution versus particle diameter) from the light-scattering patterns using Mie scattering theory. Recent comparison data obtained from the characterization of actual sludge samples during the second half of FY2009 for sludge from KW containers 240, 250, 260 and 220 is given in Table 3.4 and Figure 3.3 for easy reference (Fiskum et al. 2009). As previously stated the KW 240, 250 and 260 container sludge originated from KE Basin and should be compared to the KE container simulant while the KW 220 should be compared with the KW container simulant.

Particles with diameters between 0.02 and 1400 (2000 $\mu \mathrm{m}$ for the Hydro G dispersion unit) microns $(\mu \mathrm{m})$ can be analyzed by the instrument to determine the PSD of the simulants. However, because of the high density of some of the simulant components, large size particles (greater than $600 \mu \mathrm{m}$ ) were not introduced to the instrument/

The distribution of particles greater than $500 \mu \mathrm{m}$ for both the KW and KE simulants was determined by sieving methods; the results obtained are provided in Table 3.5 .

Before conducting any simulant slurry particle-size measurements, the PSD of a National Institute of Standards and Technology (NIST)-traceable particle-size standard was measured. The standard consisted of polydispersed (in size) silica particles with diameters falling primarily between 10 and 100 microns. The result of this measurement was compared to the standard's certificate of analysis, and the acceptable performance of the size analyzer was confirmed. The Malvern Mastersizer 2000 requires the particle refractive index (RI) to calculate the particles size. In the case of complex simulants, such as those used in this study, a trial and error approach is used to determine the particle refractive index. It was determined that little change in the PSD was observed when using an RI of 2.2 (cerium oxide) - 2.94 (ferric oxide hydroxide) with a particle-absorption index of 0 or 1 . The KE simulant materials were measured using a RI of 2.42 and an absorption index of 1; these are the parameters determined for use for the KW 240, 250, 260 and 220 real sludge samples, Fiskum 2009. All other simulants were analyzed prior to the parameter study and data was reported for a RI of 2.92 and an absorption index of 1 . 
Table 3.3. Particle-Size Analysis of K Basin Simulants After Sonication

\begin{tabular}{cccccc}
\hline & \multicolumn{5}{c}{ Cumulative Percent Less Than } \\
\cline { 2 - 6 } Size, $\mu \mathrm{m}$ & $\begin{array}{c}\text { Settler Simulant } \\
\text { ST-A }\end{array}$ & $\begin{array}{c}\text { KW-B (wet) } \\
<500 \mu \mathrm{m}\end{array}$ & $\begin{array}{c}\text { KW-B (dry) } \\
<500 \mu \mathrm{m}\end{array}$ & $\begin{array}{c}\text { KE-PNNL- } \\
500(\text { wet }) \\
<500 \mu \mathrm{m}\end{array}$ & $\begin{array}{c}\text { KE-PNNL- } \\
\text { Full (dry) } \\
<500 \mu \mathrm{m}\end{array}$ \\
\hline 800 & 99.1 & 100 & 100 & 100.0 & 100.0 \\
600 & 97.1 & 98.4 & 99.9 & 99.2 & 99.4 \\
500 & 95.0 & 96.2 & 99.3 & 98.2 & 98.7 \\
250 & 88.2 & 84.9 & 95.8 & 95.3 & 97.0 \\
100 & 87.1 & 74.2 & 92.5 & 94.6 & 96.9 \\
40 & 84.0 & 59.3 & 80.2 & 87.7 & 90.4 \\
20 & 66.2 & 45.6 & 62.6 & 73.7 & 75.3 \\
10 & 38.0 & 29.8 & 41.6 & 57.8 & 55.2 \\
5 & 19.2 & 17.0 & 24.1 & 42.1 & 35.7 \\
2.5 & 9.6 & 3.0 & 12.2 & 29.2 & 22.0 \\
1 & 3.0 & 3.0 & 3.9 & 16.8 & 10.9 \\
0.5 & 0.69 & 0.73 & 0.99 & 6.25 & 3.89 \\
\hline
\end{tabular}

Table 3.4. Particle-Size Analysis of K Basin Sludge at 1 Minute Recirculation (data from Fiskum et al. 2009)

\begin{tabular}{|c|c|c|c|c|}
\hline \multirow[b]{3}{*}{ Size, $\mu \mathrm{m}$} & \multicolumn{4}{|c|}{ Average Cumulative Percent Less Than } \\
\hline & \multicolumn{3}{|c|}{ KE origin container sludge } & \multirow{2}{*}{$\begin{array}{l}\text { KW container } \\
\text { sludge } \\
\text { KW220-SCC } \\
\left(^{(T I 010)}\right)^{(a)}\end{array}$} \\
\hline & $\begin{array}{l}\text { KW240-SCC } \\
(\text { TI010) }\end{array}$ & $\begin{array}{l}\text { KW250-SCC } \\
(\mathrm{TI} 011)^{(\mathrm{b})}\end{array}$ & $\begin{array}{l}\text { KW260-SCC } \\
(\text { TI012) })^{(\mathrm{c})}\end{array}$ & \\
\hline 800 & 100 & 100 & 99.5 & 100 \\
\hline 600 & 99.6 & 98.6 & 93.3 & 99.5 \\
\hline 500 & 98.7 & 95.8 & 85.9 & 98.2 \\
\hline 250 & 95.1 & 80.6 & 52.6 & 92 \\
\hline 100 & 92.4 & 66.3 & 38.5 & 87.3 \\
\hline 40 & 81.8 & 46.8 & 28.5 & 73.6 \\
\hline 20 & 61.4 & 33 & 21.2 & 58.7 \\
\hline 10 & 40.7 & 22.4 & 14.8 & 40.7 \\
\hline 5 & 24.1 & 14.1 & 9.4 & 23.7 \\
\hline 2.5 & 12.7 & 7.7 & 5.1 & 11.7 \\
\hline 1 & 4.53 & 2.5 & 1.4 & 3.32 \\
\hline 0.5 & 1.61 & 0.9 & 0.4 & 0.94 \\
\hline \multicolumn{5}{|c|}{ (a) Based on the average of 24 PSD measurements generated from six aliquots of sample TI010-SP } \\
\hline \multicolumn{5}{|c|}{$\begin{array}{l}\text { (b) Based on the average of } 11 \text { PSD measurements generated from two aliquots of sample } \\
\text { TI011-SP (primary) and two aliquots of TI011-SQ (duplicate). }\end{array}$} \\
\hline \multicolumn{5}{|c|}{$\begin{array}{l}\text { (c) Based on the average of } 12 \text { PSD measurements generated from two aliquots of sample } \\
\text { TI012-SP (primary) and two aliquots of TI012-SO (duplicate). }\end{array}$} \\
\hline
\end{tabular}




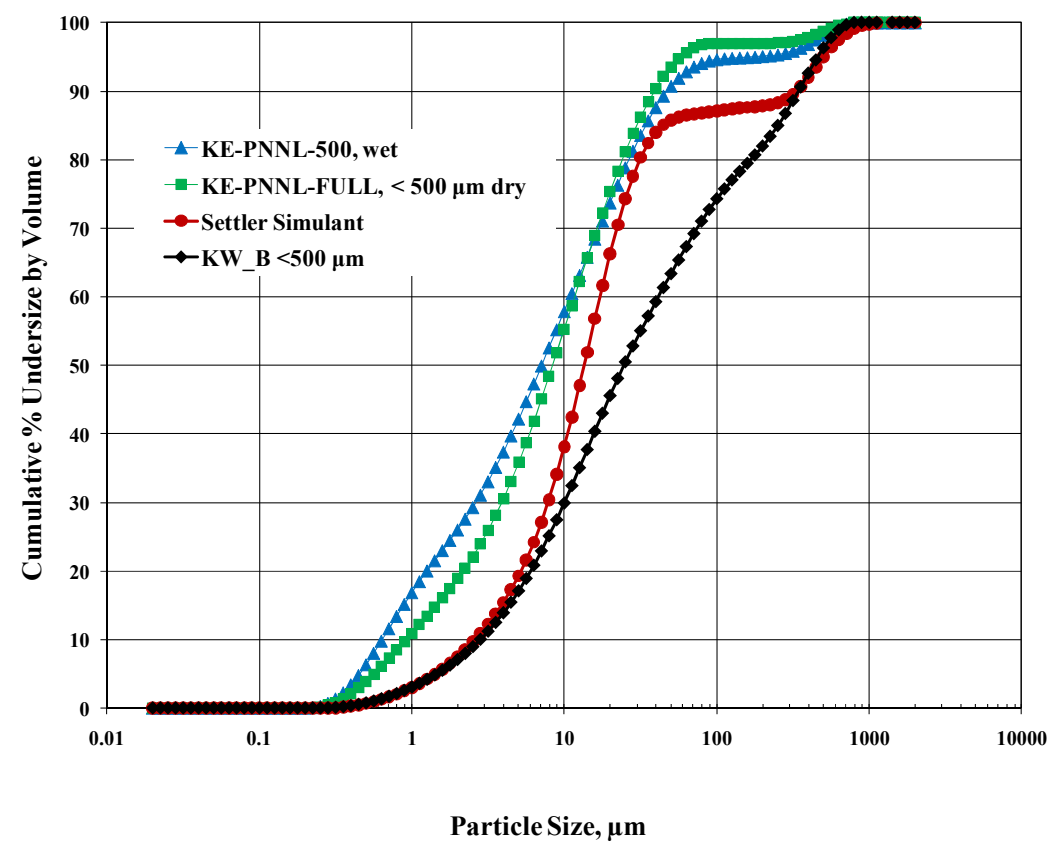

Figure 3.2. Average Cumulative Volume \% Undersize Plot After Sonication as a Function of Particle Size for Settler, KW-B $(<500 \mu \mathrm{m})$, KE-PNNL-500 $(<500 \mu \mathrm{m}$, wet) and KE-PNNL-Full, (whole simulant, dry sieved $<500 \mu \mathrm{m}$ ) Simulants

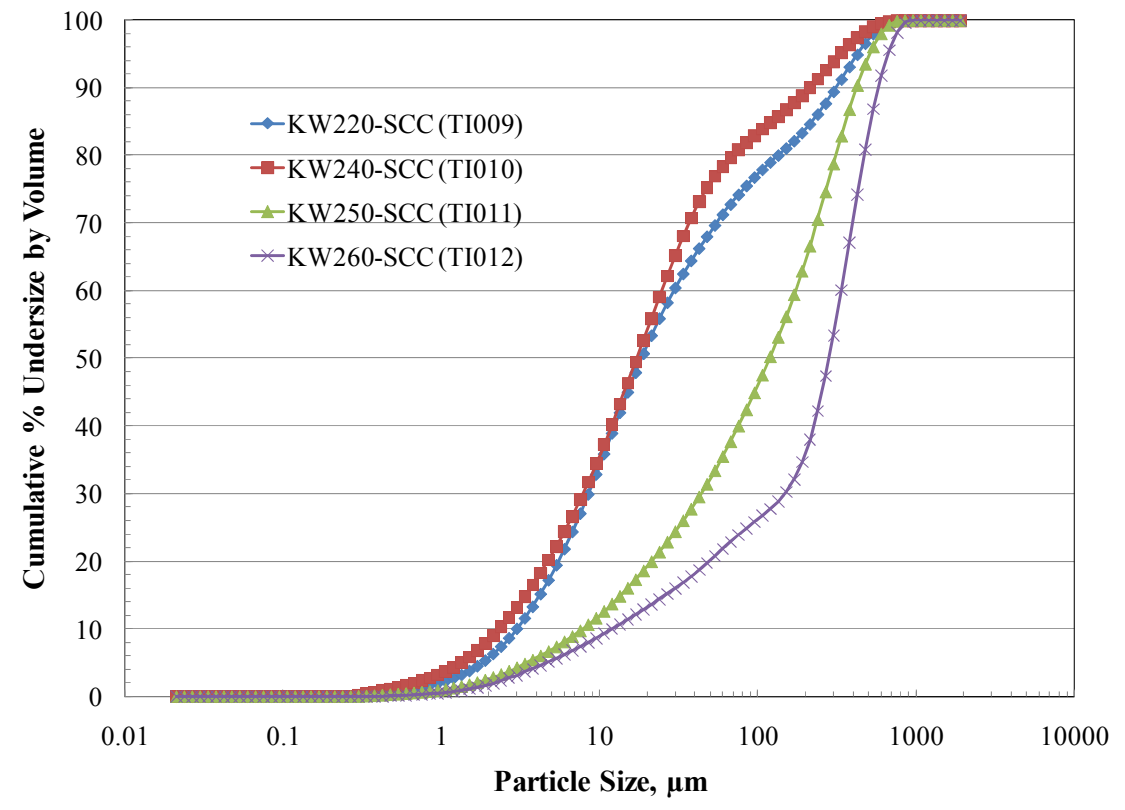

Figure 3.3. Average Cumulative Volume \% Undersize Plot Measured at 1-min Recirculation Time of KE Origin Samples KW240-SCC (TI010), KW250-SCC (TI011), and KW260-SCC (TI012) and KW Origin Sample from KW220-SCC (data taken from Fiskum et al. 2009) 


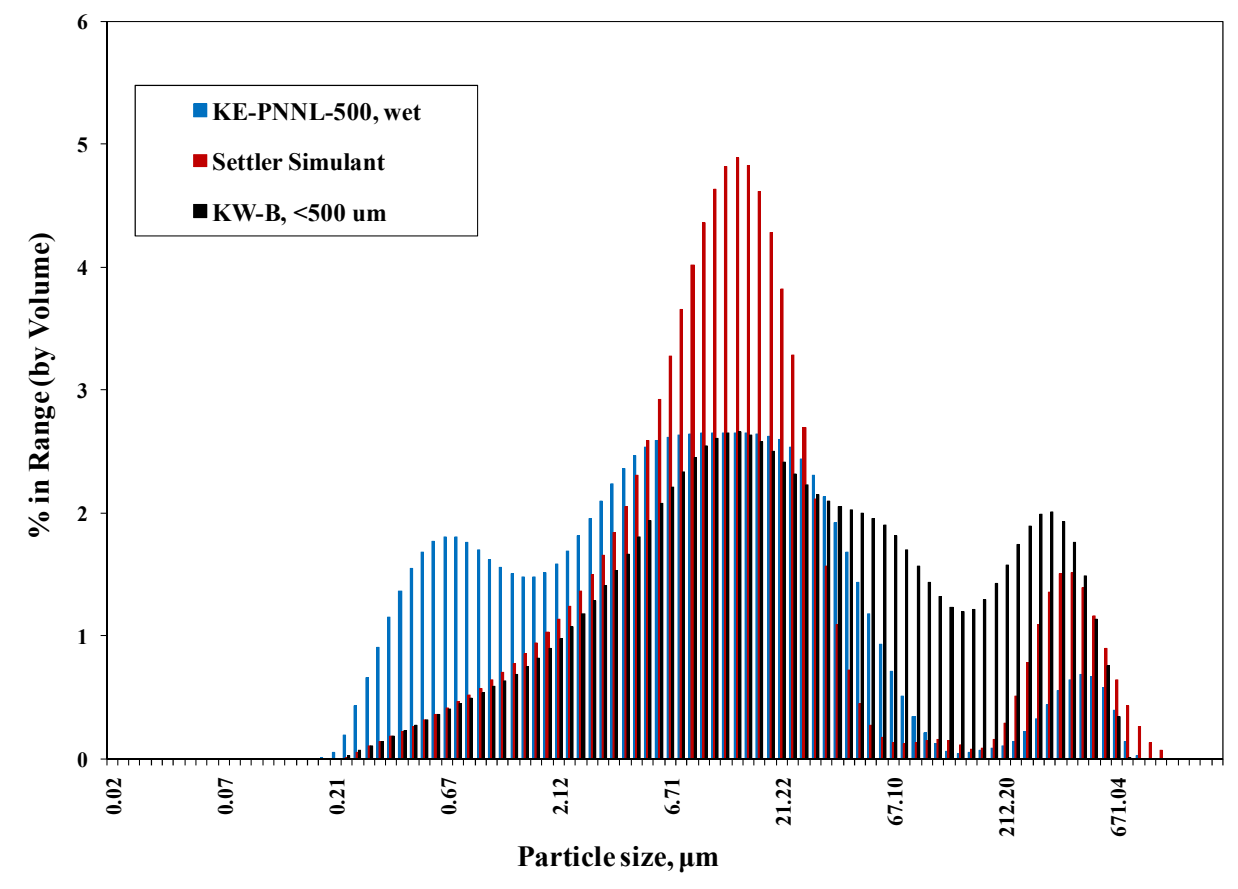

Figure 3.4. Percent in Range After Sonication, as a Function of Particle Size in Microns for a) Blue Bars, KE-PNNL-500, <500 $\mu$ m Simulant, b) Red Bars, Settler Simulant and c) Black Bars KW-B $<500 \mu \mathrm{m}$ Simulant

Table 3.5. Sieve Analysis of KW-B(P500) and KE-PNNL-Full

\begin{tabular}{ccc}
\hline $\begin{array}{c}\text { Sample Weight (g) } \\
\text { Sieve }\end{array}$ & $\begin{array}{c}149.87 \\
\text { Cumulative\% less than by mass }\end{array}$ \\
$\mu \mathrm{m}$ & KW-B (P500) & KE-PNNL-Full \\
\hline 4000 & 78.31 & 97.55 \\
2000 & 57.90 & 87.95 \\
1000 & 25.42 & 81.03 \\
500 & 0.31 & 61.30 \\
\hline
\end{tabular}

When measuring the particle size of simulant materials, small aliquots of the concentrated simulant dispersion $(<1 \mathrm{~mL})$ were diluted in deionized water in a variable-speed recirculator before taking the particle-size measurements (Hydro S or Hydro G dispersion unit). The dilution factor is determined by monitoring the amount of light obscured when passing through the diluted material - this is referred to as obscuration. Obscuration is a function of the amount of particles present and is used to determine the amount of material used for an analysis. Sufficient sample dilution to yield obscuration values of 5 to $20 \%$ are generally considered acceptable for size measurements, which corresponds to sample sizes in the range of $0.1 \mathrm{~g}$ (for fine/less-dense particles) to $2 \mathrm{~g}$ for larger/more-dense particles. Due to the presence of the cerium oxide and iron hydroxide in our simulants, very little sample was required to reach the maximum recommended obscuration value of the instrument. Measurements were performed at a pump speed of $2000 \mathrm{rpm}$. Particle-size analyzers measure volume distributions and thus are highly dependent 
on the size of particles present, given that particle volume is proportional to the cube of its diameter. Particles that have the greatest impact on the volume distribution are also those that are the most difficult to sub-sample in complex, mixed simulants like those used in this study. This is well illustrated in the PSDs obtained for the settler simulant (ST-A) in Appendix B. For comparison purposes and to illustrate the relationship between particle size and volume, an example of the PSD transformed to number $\%$ has been included for each simulant.

Simulant samples were shaken before taking aliquots for PSD analysis. Measurements were made on samples with no additional chemical treatment apart from the sample dilution required to obtain acceptable obscuration values. To determine the stability of the particles with respect to mechanical forces, measurements of particle size before, during, and after the application of sonication were taken. The use of sonication helps verify that the simulant particles are well dispersed, and no particle agglomeration or breaking or particle settling occurs during particle-size measurements.

Measuring the particle size of the settler simulant proved challenging. Specifically, it was difficult to obtain a representative sample of the settler simulant that contained both the larger particles and the finer particles without creating a bias in the results. The heterogeneity of the simulant and the variability in the component density and size range made it very difficult to obtain a representative PSD of the settler simulant. Multiple sub-samples were measured, and the cumulative average PSD along with the individual averages of each aliquot are given in Appendix B. The results given in Table 3.3 and Table 3.4 and Figure 3.2, Figure 3.3, and Figure 3.4 are based on the average of all sub-samples (settler simulants, four aliquots, Appendix B). The PSDs obtained for both the settler simulant and the KW-B $<500$ micron compare well with the target distributions given in the memorandum (MacLean 2008) that is included in Appendix A. The PSDs given in Appendix B illustrate the difficulties encountered obtaining a representative sample for the settler simulant; this is due to the optical properties of the complex simulant and the sampling difficulties. The abundance of fine particles likely causes saturation of the optical detector before the larger particles are at a concentration that can be measured. This is illustrated in sub-samples where particles greater than 100 microns were not detected. To verify that representative PSDs of such simulants are captured, multiple sub-sampling is required.

Additional consideration is needed on dilution approaches that should be pursued for PSD measurements for complex simulants and actual sludge samples. The dispersion unit used in the radiological fume hood at PNNL that is used for actual K Basin sludge calls for a 10-fold reduction in sample size (Hydro $\mu \mathrm{P}$ dispersion unit). This will increase the difficulties in obtaining a representative sample and capturing the larger, higher density particles.

\subsection{Rheological Measurements}

Shear strength is a semi-quantitative measure of the force required to move the sample and is dependent on sample history. Shear strength can be measured directly by slowly rotating a vane immersed in the sample material and recording the resulting torque as a function of time. The measured torque is converted to a shear stress by equations 3.1 and 3.2 .

$$
\tau=T / K
$$


where

$$
K=\frac{\pi D^{3}}{2}\left(\frac{H}{D}+\frac{1}{3}\right)
$$

where $\tau=$ calculated shear stress in Pascal

$\mathrm{T}=$ measured torque in Newton-meters

$\mathrm{K}=$ shear vane constant in cubic meters

$\mathrm{D}=$ shear vane diameter in meters

$\mathrm{H}=$ shear vane height in meters.

A typical stress/time profile is shown in Figure 3.5. The profile shows an initial linear region $\left(\tau_{\mathrm{y}}\right)$ followed by a nonlinear region, a stress maximum $\left(\tau_{\mathrm{s}}\right)$, and a stress decay region. The stress maximum is the transition between the visco-elastic and fully viscous flow. Shear strength is defined as the transition between these two flows and is measured at the stress maximum.

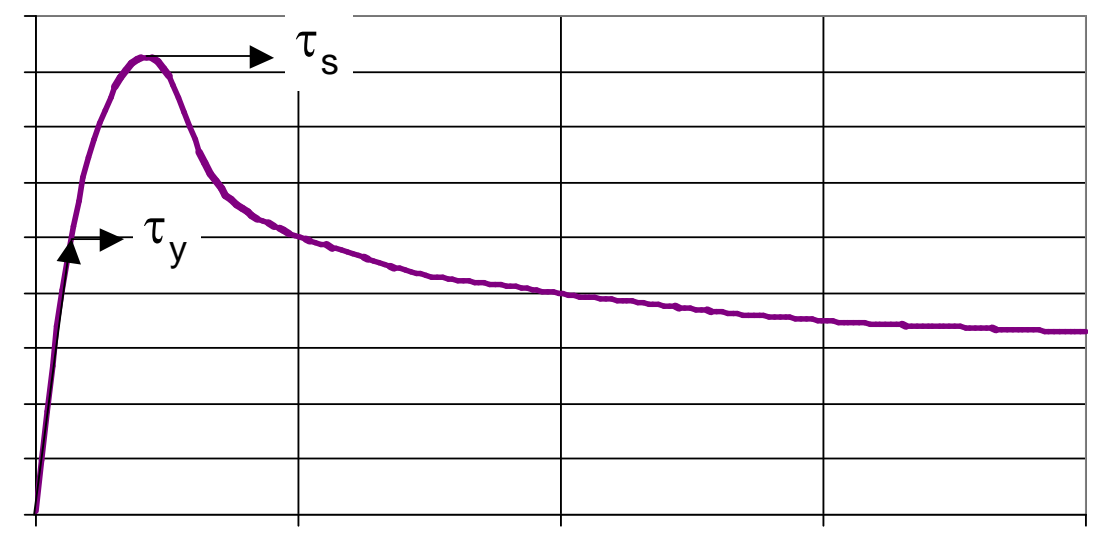

Figure 3.5. Typical Stress-Versus-Time Profile for a Shear Vane at Constant Shear Rate

In general, the test material should be saturated, fine grained, and homogeneous to provide reliable/consistent results from the shear vane test system. There are two primary force contributions to the torque measurement with the shear vane technique: 1) colloidal forces and 2) frictional forces. The colloidal forces will be dominant for slurries with smaller particles (generally under 1 to $10 \mu \mathrm{m}$ ).

Frictional forces become important for slurries with large particles (generally greater than 50 microns). Friction will vary with the depth of the slurry and the test geometry of the sample container. The K Basin simulants and sludge contain both fine and larger grain materials, and frictional forces are expected to be a significant contributor to the shear-strength measurements.

Viscosity is determined by analyzing the flow curve. The flow curve was obtained on a rheometer where shear stress can be measured as a function of shear rate. The shear rate was ramped from 0 up to $1000 \mathrm{~s}^{-1}$ (or maximum obtainable shear rate for the tool) over a 5-minute period. The shear rate was held constant at $1000 \mathrm{~s}^{-1}$ (or maximum obtainable rate) for 1 minute and then ramped back down to $0 \mathrm{~s}^{-1}$ over another 5-minute period. Standard rheological models are used to fit the flow curves and determine the 
yield stress and viscosity of the material. The calibration was checked with certified viscosity standards to verify that the rheometer is operating within acceptable tolerance ranges.

A rheogram for a material with a yield stress has two portions to it. The first portion appears as a nearly vertical line beginning at the origin and running up the ordinate. This portion of the rheogram is recording the behavior of the material as it acts like a solid or gel. When sufficient force is transmitted to the material to break the gel or make it yield, the rheogram angles sharply to the right, and from then on, the behavior of the material as a fluid is recorded. The point in the curve at which the sample transfers from a solid or gel to a fluid is the yield point. The stress at this point measured in Pascals on the ordinate is the value of the yield stress. The viscosity is the slope of the curve after the material has yielded.

The shear-strength measurements of the ST-A (settler simulant), the KW-B simulants (less than $500 \mu \mathrm{m}$ ), KE-PNNL-500 (KE container simulant, less than $500 \mu \mathrm{m}$ ), and KE-PNNL-Full (KE container simulant, full particle size distribution) are summarized in Table 3.6. The corresponding stress-versustime profiles can be found in Appendix C. The shear strength was measured for gel times of 21, 48, and 91 hours for the ST-A (settler simulant) and the KW-B simulants. For the KE container simulants, multiple measurements were collected from each sample in several sessions performed at a 48 hour gel time. At 48 hours, very good reproducibility was demonstrated as function of all measurement depths for the KE container simulants. A Haake RS600 rheometer was used to measure shear strengths for the ST-A and KW-B simulants and a Haake VT550 viscometer was used on the new simulant added in this revision, the KE container simulant. Measurements employed a shear vane tool (16 $\mathrm{mm}$ diameter by 16 $\mathrm{mm}$ height four-blade vane). The ST-A and KW-B samples were measured in $250-\mathrm{mL}$ wide-neck Nalgene bottles at two different measurement depths, the middle of the container and the bottom (1 times the vane diameter from container bottom). No temperature control was employed during shear-strength measurement. Recent comparison data obtained from the characterization of actual sludge samples during the second half of FY2009 for sludge from KW containers 240, 250, 260 and 220 is given in Table 3.7 for easy reference (Fiskum et al. 2009). The KE container simulants were measured in two different container types to observe any container size effects that may result in differences in settling behavior which would impact shear strength measurements. Firstly a $700 \mathrm{~mL}$ plastic container was used which permitted triplicate measurements and still met the geometry requirements for a valid shear strength measurement in accordance with RPL-COLLOID-02, Rev. 1. Routinely the center was measured first, followed by the right hand side (RHS) and finally the left hand side (LHS). It has been observed previously that when multiple measurements are taken within the same container, even when the geometry requirements for a suitable container size are met, depending on the material behavior, removal of the shear vane results in sample disturbance; this was not observed for the KE container simulant. Secondly a $120 \mathrm{~mL}$ Qorpak jar was used that only permits one measurement down the center. The $120 \mathrm{~mL}$ Qorpak jar is a typical vessel used for hot cell rheology measurements on actual K Basin sludge and was used here for two reasons: firstly, in the event that making multiple measurements in the larger container affected measurement results; and secondly, to observe any settling differences due to the container geometry as previously stated.

From Table 3.6, we can see that measurements taken at the bottom of the settler simulant container as opposed to the middle exhibited greater shear strengths. These values were not included in the average value given in Table 3.6. The settler simulant appeared to have a gradient throughout the container, most probably because of particle settling and continued dewatering of the simulant. This behavior was not observed in the KW-B and KE container simulants. All simulants were very difficult to mix with the 
exception of the KE container simulant, and required considerable force to re-suspend them between measurements. The KE container simulant was the least difficult to re-suspend, and was very creamy in consistency, especially the $<500 \mu \mathrm{m}$ fraction.

It should be noted that the shear strength of the KW-B simulant more than doubled after fines (settled out of the water removed during dewatering, $<0.5 \mathrm{~g}$ ) were reintroduced into the container and mixed on the top. This observation is most likely due to vibration/packing effects of the simulant during partial mixing and has been reported here because of the magnitude of the change observed. The simulant was split into two equal parts to facilitate the performance of parallel experiments; both parts underwent the same dewatering/mixing process with the final dewatering carried out on the split samples. Care was taken to handle both samples in the same manner with mass balance of the water removed per bulk mass of simulant present in the containers taken into account and kept constant for both samples. This observation/measurement provides an indication of the sensitivity of shear strength to very small changes in the simulant handling, make-up, and water content. While not included in the average value calculated and reported in Table 3.6, the high value for KW-B is reported in Table 3.6 because the magnitude of the measurement is comparable to that observed in Schmidt and Zacher (2007) after a settler tank simulant was transported in a vehicle. 
Table 3.6. Simulant Shear-Strength Measurements

\begin{tabular}{|c|c|c|c|c|c|c|}
\hline \multicolumn{7}{|l|}{ KW-B (M-500) Shear-Strength Measurements } \\
\hline Conditions & $\begin{array}{c}\text { Gel Time } \\
\text { (hours) }\end{array}$ & \multicolumn{2}{|c|}{ Shear Strength $(\mathrm{Pa})$} & $\begin{array}{l}\text { Average } \\
\text { (a) }\end{array}$ & & STDEV \\
\hline * Vane Immersion Depth, $1.6 \mathrm{~cm}$ & 21 & \multicolumn{2}{|c|}{2350} & & & \\
\hline ++Added fines and mixed top, Vane Immersion Depth, $1.6 \mathrm{~cm}$ & 48 & \multicolumn{2}{|c|}{5715} & & & \\
\hline * Vane Immersion Depth $3.2 \mathrm{~cm}$ & 21 & \multicolumn{2}{|c|}{1597} & & & \\
\hline * Vane Immersion Depth, $1.6 \mathrm{~cm}$ & 24 & \multicolumn{2}{|c|}{1209} & 1719 & \pm & 580 \\
\hline Vane Immersion Depth, $1.6 \mathrm{~cm}$ & 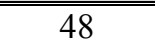 & \multicolumn{2}{|c|}{797} & & & \\
\hline * Vane Immersion Depth $3.2 \mathrm{~cm}$ & 48 & \multicolumn{2}{|c|}{1174} & 986 & \pm & 266 \\
\hline * Vane Immersion Depth, $1.6 \mathrm{~cm}$ & 91 & \multicolumn{2}{|c|}{1543} & & & \\
\hline * Vane Immersion Depth $3.2 \mathrm{~cm}$ & 91 & \multicolumn{2}{|c|}{1495} & 1519 & \pm & 34 \\
\hline \multicolumn{7}{|l|}{+++ not included in average value } \\
\hline \multicolumn{7}{|l|}{ ST-A Shear-Strength Measurements } \\
\hline Conditions & $\begin{array}{l}\text { Gel Time } \\
\text { (hours) }\end{array}$ & \multicolumn{2}{|c|}{ Shear Strength $(\mathrm{Pa})$} & $\begin{array}{l}\text { Average } \\
\text { (a) }\end{array}$ & & STDEV \\
\hline * Vane Immersion Depth, $1.6 \mathrm{~cm}$ & 21 & \multicolumn{2}{|c|}{516} & & & \\
\hline * Vane Immersion Depth, $1.6 \mathrm{~cm}$ & 24 & \multicolumn{2}{|c|}{465} & & & \\
\hline * Vane Immersion Depth $3.2 \mathrm{~cm}$ & 24 & \multicolumn{2}{|c|}{627} & 536 & \pm & 83 \\
\hline Vane Immersion Depth, $1.6 \mathrm{~cm}$ & 48 & \multicolumn{2}{|c|}{612} & & & \\
\hline * Vane Immersion Depth, $1.6 \mathrm{~cm}$ & 91 & \multicolumn{2}{|c|}{604} & & & \\
\hline * Vane Immersion Depth $3.2 \mathrm{~cm}$ & 91 & \multicolumn{2}{|c|}{1214} & 909 & \pm & 431 \\
\hline \multicolumn{7}{|c|}{ * Average and STDEV include both midpoint and bottom measurements based on gel time. } \\
\hline \multicolumn{7}{|l|}{ KE-PNNL-500 Shear-Strength Measurements } \\
\hline \multirow[b]{2}{*}{ Conditions } & \multirow{2}{*}{$\begin{array}{l}\text { Gel Time } \\
\text { (hours) }\end{array}$} & \multicolumn{3}{|c|}{ Shear Strength $(\mathrm{Pa})$} & Average & \\
\hline & & Center & RHS & LHS & (a) & STDEV \\
\hline \multirow{4}{*}{ Vane Immersion Depth, $1.6 \mathrm{~cm}$} & $\sim 48$ & 627.1 & 589.8 & 720.4 & & \\
\hline & $\sim 48$ & 580.5 & 526.9 & 552.5 & & \\
\hline & $\sim 48$ & 517.6 & & & & \\
\hline & $\sim 48$ & 404.5 & & & 565 & \pm 91 \\
\hline Vane Immersion Depth $3.2 \mathrm{~cm}$ & 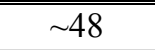 & 719.2 & 655.1 & 797.3 & & \\
\hline & $\sim 48$ & 605 & 551.4 & 678.4 & & \\
\hline & $\sim 48$ & 681.9 & & & & \\
\hline & $\sim 48$ & 708.7 & & & 675 & \pm 74 \\
\hline KE-PNNL-Full Shear-Strength Measurements & & & & & & \\
\hline & Gel Time & She & Strength & $\mathrm{Pa})$ & Average & \\
\hline Conditions & (Hours) & Center & RHS & LHS & (a) & STDEV \\
\hline Vane Immersion Depth, $1.6 \mathrm{~cm}$ & $\sim 48$ & 1503 & 1116 & 1568 & & \\
\hline & $\sim 48$ & 1112 & 955.9 & 1041 & & \\
\hline & $\sim 48$ & 1310 & & & & \\
\hline & $\sim 48$ & 975.7 & & & 1198 & \pm 236 \\
\hline Vane Immersion Depth $3.2 \mathrm{~cm}$ & 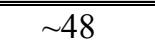 & 1551 & & 2071 & & \\
\hline & $\sim 48$ & 1550 & 1311 & 1510 & & \\
\hline & $\sim 48$ & 1486 & & & & \\
\hline & $\sim 48$ & 1511 & & & 1570 & \pm 236 \\
\hline
\end{tabular}

(a) Unless otherwise stated, all measurements for a given set of conditions was used to calculate average value. 
Table 3.7. Shear Strengths of Actual Sludge Samples

[from KE Origin containers 240, 250, 260 and KW Origin container 220

(minus $500 \mu \mathrm{m}$ fractions) from Fiskum et al. 2009]

\begin{tabular}{|c|c|c|c|c|c|c|}
\hline Sample ID & Test & $\begin{array}{c}\text { Temperature } \\
\left({ }^{\circ} \mathrm{C}\right)\end{array}$ & $\begin{array}{c}\text { Settling } \\
\text { Time (hr) }\end{array}$ & Location & $\begin{array}{c}\text { Immersion } \\
\text { Depth (mm) }\end{array}$ & $\begin{array}{c}\text { Shear Strength } \\
(\mathrm{Pa})\end{array}$ \\
\hline \multirow{4}{*}{$\begin{array}{l}\text { TI009-SO } \\
(220)^{(\mathrm{a})}\end{array}$} & 1 & 28.0 & As-Received & Center & 0 & $\mathrm{n} / \mathrm{m}$ \\
\hline & 2 & 27.1 & 73 & Center & 8 & $\sim 500^{(\mathrm{c})}$ \\
\hline & 3 & -- & -- & Center & -- & -- \\
\hline & 4 & 23.8 & 73 & Center & 8 & $\sim 90^{(\mathrm{c})}$ \\
\hline \multirow{5}{*}{$\begin{array}{c}\text { TI010-SO } \\
\text { (KW240- } \\
\text { SCC) }\end{array}$} & 1 & 28.4 & As-Received & Center & 16 & 370 \\
\hline & 2 & 27.1 & 73 & Center & 16 & 510 \\
\hline & 3 & 25.6 & 70 & Center & 16 & 130 \\
\hline & 4 & 23.5 & 73 & Center & $\sim 20$ & 220 \\
\hline & Avg (2-4) & & & & & $300 \pm 200^{(\mathrm{b})}$ \\
\hline \multirow{5}{*}{$\begin{array}{c}\text { TI011-SO } \\
\text { (KW250- } \\
\text { SCC) }\end{array}$} & 1 & 28.7 & As-Received & Center & 16 & 380 \\
\hline & 2 & 27.1 & 74 & Center & $\sim 16$ & 410 \\
\hline & 3 & 25.7 & 70 & Center & 16 & 220 \\
\hline & 4 & 23.6 & 73 & Center & $\sim 16$ & 290 \\
\hline & $\operatorname{Avg}(2-4)$ & & & & & $300 \pm 100^{(\mathrm{b})}$ \\
\hline \multirow{5}{*}{$\begin{array}{c}\text { TI012-SO } \\
\text { (KW260- } \\
\text { SCC) }\end{array}$} & 1 & 28.8 & As-Received & Center & 16 & 300 \\
\hline & 2 & 27.1 & 74 & Center & 16 & 81 \\
\hline & 3 & 25.8 & 71 & Center & 16 & 81 \\
\hline & 4 & 23.6 & 73 & Center & $\sim 16$ & 76 \\
\hline & $\operatorname{Avg}(2-4)$ & & & & & $79 \pm 3^{(b)}$ \\
\hline
\end{tabular}

(a) All tests for sample TI009-SO were performed at partial vane immersions because there were insufficient settled solids for a reliable shear-strength measurement.

(b) Reported uncertainty is twice the standard error of the mean (which approximated the lower bound of the $95 \%$ confidence limits).

(c) Result corrected for partial immersion

The flow-curve analyses for the settler sample and KW-B M500 sample were attempted several times using the concentric cylinder and vane sensor on the TA Rheometer and the Haake RS 600 rheometer. An attempt to measure the KE container sludge simulant using the Haake VT550 and the M5 with a MV2P geometry routinely used in the hot cells for actual sludge flow curve measurements, was also unsuccessful. Particle interaction within the sludge during analysis caused flocculation/agglomeration of the particles. It is suspected that the clustering of particles created a particle bridge in the 1-mm gap between cup and rotor for the settler sample and the KW-B M500 samples, causing the sensors on both rheometers to stick. Sticking caused the instruments to exceed their maximum allowable torque, which triggers the instrument to terminate the flow-curve analysis to prevent damage to the instrument. The MV2P geometry has a $2.6 \mathrm{~mm}$ gap and the KE simulant sample exceeded the initial yield stress of this measuring geometry.

Flow-curve analyses were also attempted with the vane rheometer setup. However, due to the nature of the rapidly settling simulant, consistent/reportable results were not obtained. Different geometries need to be investigated using this setup to determine if this method is suitable for these types of simulants. 
One major consideration in performing a valid rheological measurement of a sample is to identify the necessary gap size between the sensor and the cup to verify that the particle size (in this case agglomeration of particles) does not affect the measurement of the flow curve. In our case, the $\sim 1-\mathrm{mm}$ gap was not sufficiently large, and as such, it was not possible to measure the flow properties of the simulants using the concentric cylinder and vane sensor. Therefore, the flow-curve analysis was performed on the TA Rheometer using a parallel plate geometry at room temperature. Sample dilution was not attempted using this setup because this technique is limited to concentrated/viscous samples. Initially, a plate distance of $1 \mathrm{~mm}$ was used, which once again resulted in particle bridging/jamming. The minimum plate gap required for this method is three times the largest particle present in the sample being analyzed. Optimally, a gap size of 10 times the largest particle is desired where practically possible. Next, a 3-mm plate gap was used to measure the flow curves and obtain viscosity plots (Figure 3.6 and Figure 3.7 and Appendix C). Slurry particles were seen to agglomerate at the edges of the two plates while taking measurements. The parallel plate was also used to measure the flow curve of the KE container simulant; both 2 and $3 \mathrm{~mm}$ gaps were investigated and measurements were taken at 20 and $30^{\circ} \mathrm{C}$. A summary of down fits using the Bingham model for all the simulants is given in Table 3.8. Recent comparison data obtained from the characterization of actual sludge samples during the second half of FY2009 for sludge from KW containers 240, 250, and 260 is given in Table 3.9 for easy reference (Fiskum et al. 2009).

Both the settler and the KW-B simulants were measured in triplicate, and all plots associated with these measurements can be found in Appendix C. The KE container simulant was measured a total of 5 times for both the full and $<500 \mu \mathrm{m}$ simulant samples, the plots associated with these measurements can also be found in Appendix C. The up-ramp data indicate significant yield strength. From Figure 3.6 and Figure 3.7, it can be seen that the up-ramp is highly non-linear, possibly indicating structural disruption or possibly bridging effects, even in the 3-mm-gap data. 


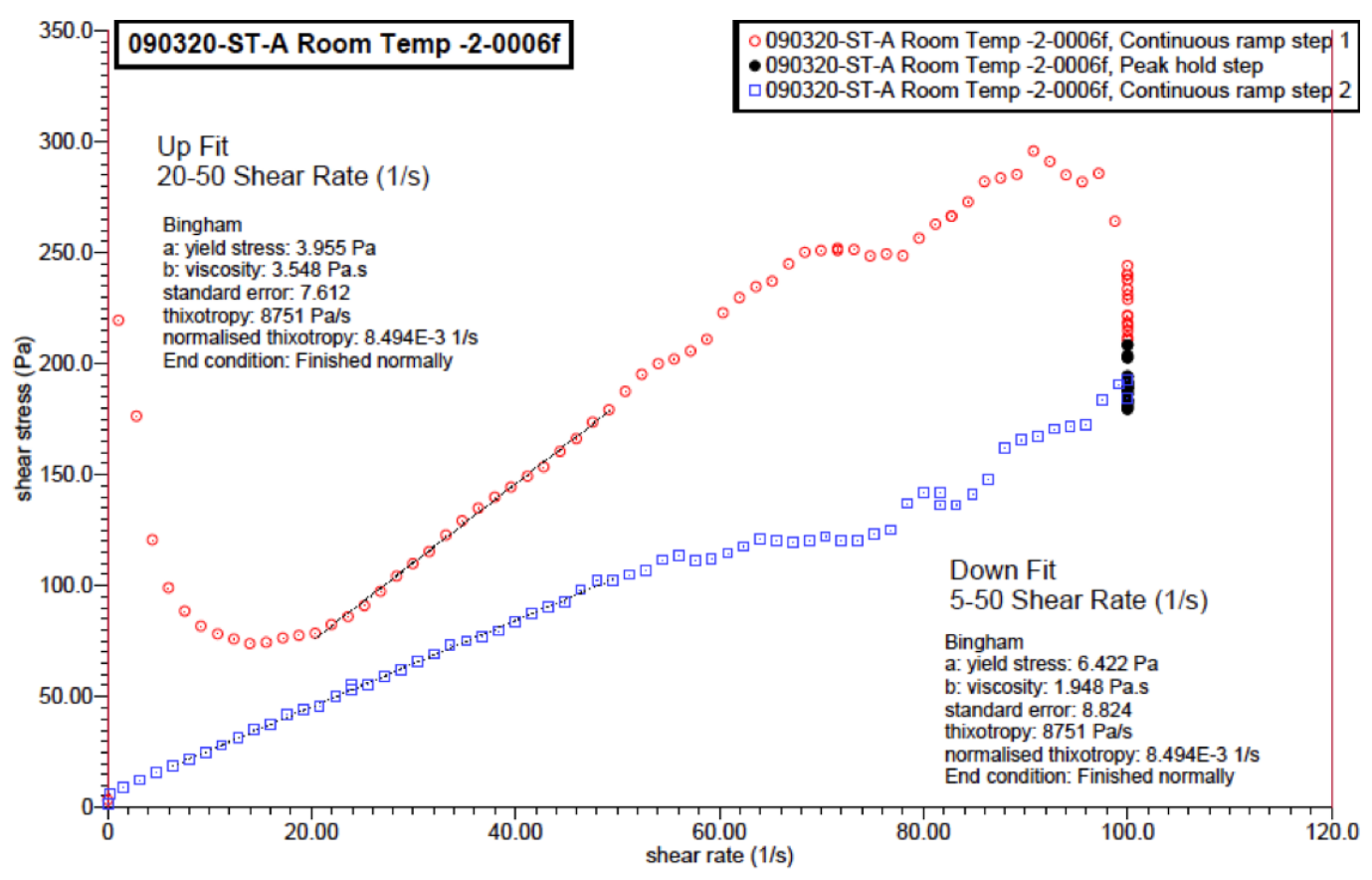

Figure 3.6. Shear Stress Versus Shear Rate of Settler Simulant

The observed hysteresis is indicative of significant structural changes to the sample upon shearing, which is typical for dense slurries. The down-ramp data obtained are most likely indicative of the well mixed, fully disrupted slurry rheology, and show a relatively linear, Bingham-type stress response. Optimization of measuring shear strength needs to be investigated for these difficult materials.

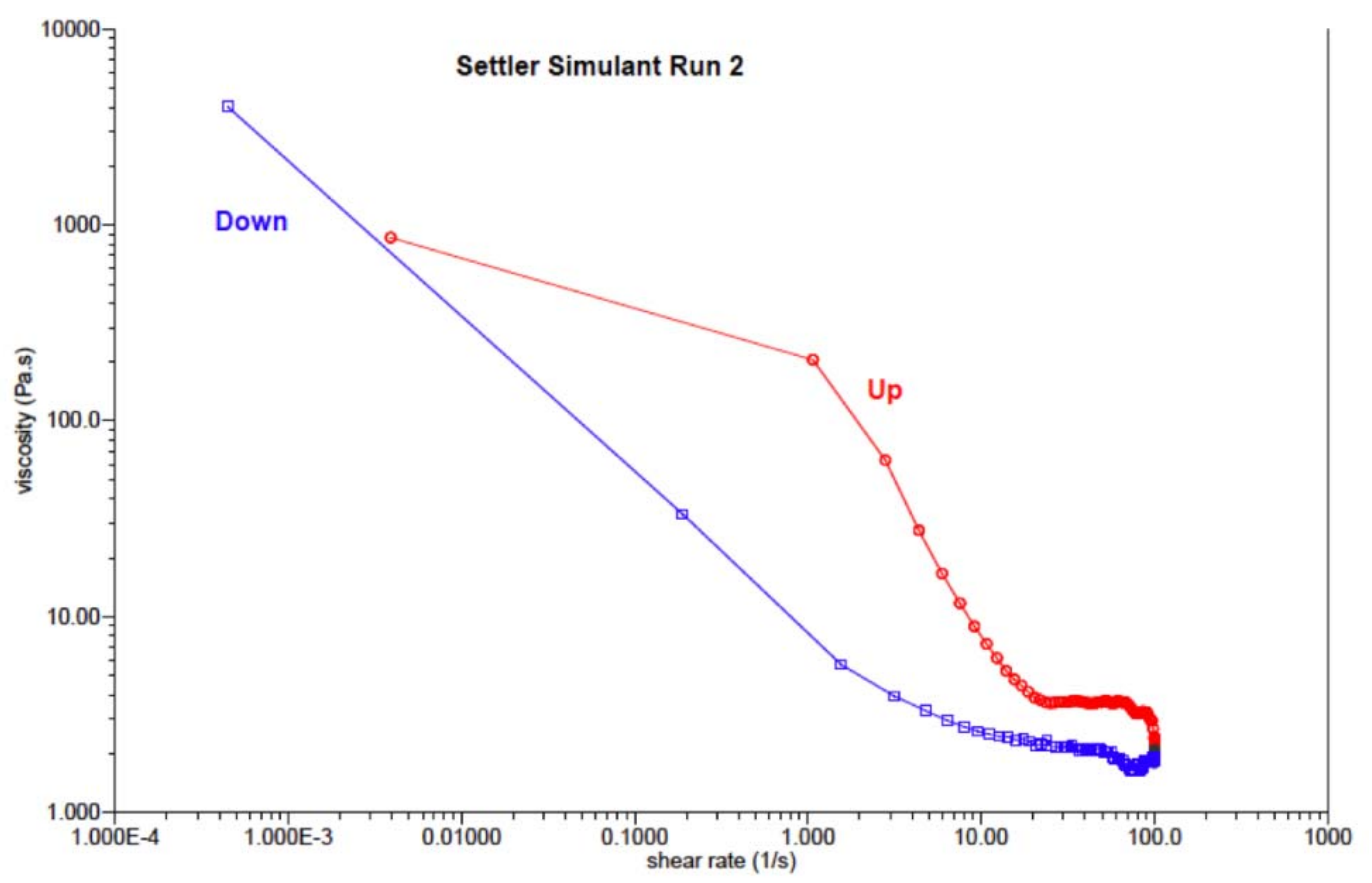

Figure 3.7. Viscosity Versus Shear Rate Obtained for the Settler Simulant shown in Figure 3.6 
Table 3.8. Bingham-Plastic Down Fits for Simulants

\begin{tabular}{|c|c|c|}
\hline \multirow[b]{2}{*}{ Run Number } & \multicolumn{2}{|c|}{ Down Fit } \\
\hline & Yield Stress, $\tau_{\mathrm{O}}^{\mathrm{B}}(\mathrm{Pa})$ & $\begin{array}{c}\text { Consistency, } \mathrm{k}_{\mathrm{B}} \\
(\mathrm{Pa} \cdot \mathrm{s})\end{array}$ \\
\hline \multicolumn{3}{|c|}{ ST-A, Room Temp $\left(\sim 20^{\circ} \mathrm{C}\right)$} \\
\hline 1 & 6.007 & 2.35 \\
\hline 2 & 6.422 & 1.948 \\
\hline 3 & 6.692 & 2.396 \\
\hline Average & $6.4 \pm 0.4$ & $2.2 \pm 0.2$ \\
\hline \multicolumn{3}{|c|}{ KW-B (M-500), Room Temp $\left(\sim 20^{\circ} \mathrm{C}\right)$} \\
\hline 1 & 21.86 & 3.402 \\
\hline 2 & 27.39 & 2.248 \\
\hline 3 & 21.51 & 1.63 \\
\hline Average & $23.6 \pm 3.3$ & $2.4 \pm 0.9$ \\
\hline \multicolumn{3}{|l|}{ KE-PNNL-500, $20^{\circ} \mathrm{C}$} \\
\hline 1 & 40.63 & 12.64 \\
\hline 2 & 42.2 & 14.43 \\
\hline 3 & 26.96 & 15.2 \\
\hline 4 & 18.72 & 14.20 \\
\hline 5 & 19.08 & 14.29 \\
\hline Average & $28.5 \pm 11.4$ & $14.2 \pm 0.9$ \\
\hline \multicolumn{3}{|l|}{ KE-PNNL-500, $30^{\circ} \mathrm{C}$} \\
\hline 1 & 46.49 & 9.166 \\
\hline 2 & 78 & 3.662 \\
\hline 3 & 42.07 & 1.775 \\
\hline 4 & 22.16 & 8.933 \\
\hline 5 & 32.05 & 8.818 \\
\hline Average & $44.2 \pm 21.1$ & $6.5 \pm 3.5$ \\
\hline
\end{tabular}

Table 3.9. Bingham-Plastic Fits for Actual Sludge Samples from Containers 240, 250 and 260 (taken from Fiskum et al. 2009)

\begin{tabular}{cccc}
\hline Sample & $\begin{array}{c}\text { Temperature } \\
\left({ }^{\circ} \mathrm{C}\right)\end{array}$ & $\begin{array}{c}\text { Yield Stress, } \tau_{\mathrm{O}}{ }^{\mathrm{B}} \\
(\mathrm{Pa})\end{array}$ & $\begin{array}{c}\text { Consistency, } \mathrm{k}_{\mathrm{B}} \\
(\mathrm{Pa} \cdot \mathrm{s})\end{array}$ \\
\hline TI010-SO & 20 & $42.5 \pm 1.8$ & $0.152 \pm 0.007$ \\
$($ KW240-SCC $)$ & 30 & $47.9 \pm 3.4$ & $0.105 \pm 0.013$ \\
\hline TI011-SO & 20 & $26.5 \pm 1.1$ & $0.171 \pm 0.005$ \\
$($ KW250-SCC) & 30 & $24.1 \pm 0.9$ & $0.126 \pm 0.004$ \\
\hline TI012-SO & 20 & $21.4 \pm 0.5$ & $0.066 \pm 0.002$ \\
$($ KW260-SCC $)$ & 30 & $16.3 \pm 0.4$ & $0.047 \pm 0.001$
\end{tabular}

All uncertainties reported represent twice the standard error of the regressed model parameters 


\subsection{Reporting}

Experimental data have been recorded in an official PNNL Laboratory Record Book where laboratory notes were taken. A test instruction (TI) was written and used to document the KE simulant work presented in this report, 53451-TI37, "KE Container Sludge Simulant Characterization".

An independent review of the electronic files used for data analysis has been executed. 


\subsection{References}

Baker RB, JA Pottmeyer, JL Westcott, AJ Schmidt, and TL Welsh. 2009. Quality Assurance Project Plan/Sampling and Analysis Plan for Sludge in the KW Engineered Containers, KBC-33786, Rev. 1, CH2M Hill Plateau Remediation Company, Richland, Washington.

Burbank DA. 2010. Sludge Simulant Strategy and Design Basis, PRC-STP-00034, Rev. 1, CH2M Hill Plateau Remediation Company, Richland, Washington.

Daniel RC. 2007. PNNL Technical Procedure: Measurement of Physical and Rheological Properties of Solutions, Slurries and Sludges, RPL-COLLOID-02, Rev. 1, Pacific Northwest National Laboratory, Richland, Washington.

Fiskum SK, JM Billing, SJ Bos, CA Burns, CD Carlson, DS Coffey, JV Crum, RC Daniel, CH Delegard, MK Edwards, OT Farmer, LR Greenwood, SA Jones, D Neiner, BM Oliver, KN Pool, AJ Schmidt, RW Shimskey, CZ Soderquist, ML Thomas, CJ Thompson, T Trang-Le, and MW Urie. 2009. Characterization Data Package for Containerized Sludge Samples Collected from Engineered Containers SCS-CON-240, 250, 260, and 220, PNNL-19035, Rev. 0, Pacific Northwest National Laboratory, Richland, Washington.

Johnson ME. 2010. Screening Evaluation of Characterization Data for Engineered Container SCS-CON-220, -240, -250, -260, PRC-STP-0012, Rev.1, CH2M Hill Plateau Remediation Company, Richland, Washington.

Plys MG and AJ Schmidt. 2006. Supporting Basis for Spent Nuclear Fuel Project Sludge Technical Databook. SNF-7765, Rev. 3C, CH2M Hill Plateau Remediation Company.

Schmidt AJ. 2009. Spent Nuclear Fuel Project Technical Databook, Vol. 2, "Sludge," Rev. 14, HNF-SD-SNF-TI-015, Fluor Hanford, Inc. Richland, Washington.

Schmidt AJ and AH Zacker. 2007. Composition and Technical Basis for K Basin Settler Sludge Simulant for Inspection, Retrieval and Pump Testing, PNNL-16619, Rev 1, Pacific Northwest National Laboratory, Richland, Washington. 
Appendix A

\section{Simulant Material Provided to Pacific Northwest National Laboratory}




\section{Appendix A: Simulant Material Provided to Pacific Northwest National Laboratory}

These simulant formulations and copies of chain-of-custody documents are included in this Appendix. The simulant compositions are documented in a memorandum. ${ }^{(a)}$

1) Sludge Treatment Project Base Simulant Recipes

2) Settler Tank Simulant, ST-A

Chain of Custody

Simulant Preparation Data Sheet

Simulant Component Source Data

Characterization Request

3) KW Container Simulant, KW-A, Complete

Chain of Custody

Simulant Preparation Data Sheet

Simulant Component Source Data

Characterization Request

4) KW Container Simulant, KW-B, P500 and M500 (size fractionated)

Chain of Custody

Simulant Preparation Data Sheet

Simulant Component Source Data

Characterization Request

5) KE Container Simulant, KE-PNNL-500 (<500 $\mu \mathrm{m})$ and KE-PNNL-Full, Complete

Chain of Custody

Simulant Preparation Data sheets

Simulant Component Source Data

(a) GT MacLean. 2008. K Basin Sludge Simulants. Letter Report from GT MacLean (Fluor Government Group) to R Lokken, August 7, 2008, Fluor Government Group, Richland, Washington. 
Fluor Government Group

Richland Office

1200 Jadwin Avenue, PO Box 1050

Richland, WA 99352-1050

509.372 .0405

509.373 .6471

\section{Memorandum}

$\begin{array}{llll}\begin{array}{l}\text { To: } \\ \text { Location: }\end{array} & \begin{array}{l}\text { Ryan Lokken } \\ 4710 / 309 / 400\end{array} & \begin{array}{l}\text { Date: } \\ \text { Reference: }\end{array} & \text { 08/07/2008 } \\ \begin{array}{l}\text { From: } \\ \text { Location: }\end{array} & \begin{array}{l}\text { Graham MacLean } \\ \text { 1200 Jadwin/247 }\end{array} & \text { Client: } & \text { FH } \\ & & & \\ \text { Phone: } & 372-0405 & \text { Subject: } & \text { K-Basin Sludge Simulants } \\ \text { FAX: } & 373-6471 & & \\ & & & \\ \text { c: } & \text { Andy Schmidt } & \text { P8-60 } & \end{array}$

Primary or base recipes (formulations) have been selected for mixtures that represent the combined sludges in three groupings:

1. KE Basin origin sludges that currently reside in KW Containers 240, 250, and 260

2. KW Basin sludges that currently and will reside in KW Containers 210 and 220

3. KW Settler-tube sludge that will reside in $\mathrm{KW}$ container 230

The KE Basin and KW settler-tube sludge recipes have been selected from those listed in Table 2 of A21C-STP-TI-0001, Rev. 0, "K Basin Sludge Simulant Recipe Book." The identifications are shown in parentheses in the tables below. The KW Basin sludge recipe, also shown below, was developed after the initial Recipe Book was issued. Data tables and particle size plots are include to show an example composition that meets the specifications.

KE Basin Container Sludge Simulant (\#11 - modified rheology simulant based on 93 vol.\% KE floor sludge and 7 vol.\% KE canister sludge)

\begin{tabular}{c|c|c|}
\hline Material & Amount, wt. $\%$ & Particle Size Specification \\
\hline $\mathrm{FeOOH}$ or $\mathrm{Fe}(\mathrm{OH})_{3}$ & 32.1 & $\mathrm{~d}_{10}=6 \mu \mathrm{m}, \mathrm{d}_{50}=13 \mu \mathrm{m}, \mathrm{d}_{90}=19 \mu \mathrm{m}$ \\
\hline Sand & 24.1 & $\mathrm{~d}_{10}=.17 \mathrm{~mm}, \mathrm{~d}_{50}=.30 \mathrm{~mm}, \mathrm{~d}_{90}=.56 \mathrm{~mm}$ \\
\hline Aggregate & 14.3 & $\mathrm{~d}_{10}=2.0 \mathrm{~mm}, \mathrm{~d}_{50}=2.8 \mathrm{~mm}, \mathrm{~d}_{90}=4.0 \mathrm{~mm}$ \\
\hline $\mathrm{Al}(\mathrm{OH})_{3}$ & 12.1 & $\mathrm{~d}_{10}=2 \mu \mathrm{m}, \mathrm{d}_{50}=13 \mu \mathrm{m}, \mathrm{d}_{90}=47 \mu \mathrm{m}$ \\
\hline $\mathrm{CeO}_{2}$ or equivalent & 12.1 & $\mathrm{~d}_{10}=.5 \mu \mathrm{m}, \mathrm{d}_{50}=4 \mu \mathrm{m}, \mathrm{d}_{90}=19 \mu \mathrm{m}$ \\
\hline Steel Grit or equivalent & 4.1 & $\mathrm{~d}_{10}=1.9 \mathrm{~mm}, \mathrm{~d}_{50}=2.3 \mu \mathrm{m}, \mathrm{d}_{90}=2.7 \mu \mathrm{m}$ \\
\hline Dense metal or alloy & 1.2 & $\mathrm{~d}_{10}=.30 \mathrm{~mm}, \mathrm{~d}_{50}=.60 \mathrm{~mm}, \mathrm{~d}_{90}=1.41 \mathrm{~mm}$ \\
\hline Total & 100.0 & $\mathrm{~d}_{10}=4 \mu \mathrm{m}, \mathrm{d}_{50}=20 \mu \mathrm{m}, \mathrm{d}_{90}=2.6 \mathrm{~mm}$ \\
\hline
\end{tabular}




\begin{tabular}{|c|c|c|c|c|c|c|c|c|c|}
\hline 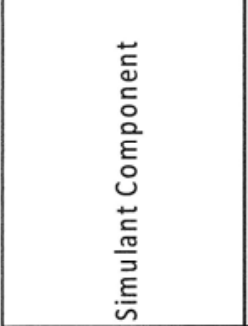 & 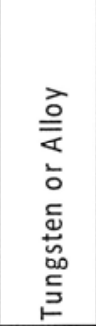 & 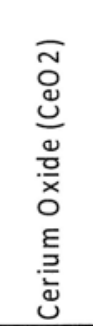 & 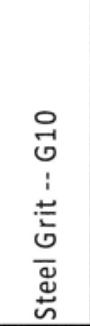 & 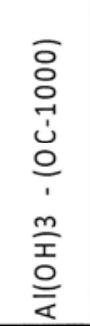 & 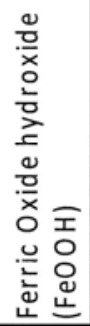 & 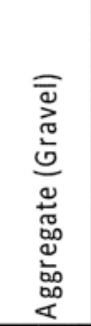 & 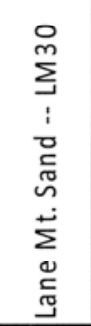 & 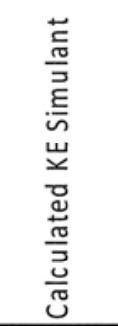 & 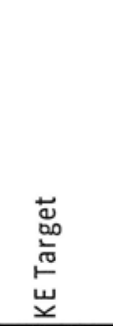 \\
\hline Wt. \%, dry & 1.2 & 12.1 & 4.1 & 12.1 & 32.1 & 14.3 & 24.1 & 100.0 & \\
\hline $\begin{array}{c}\text { Particle Density, } \\
\mathrm{g} / \mathrm{cm}^{3}\end{array}$ & 16.9 & 7.13 & 7.86 & 2.42 & 2.85 & 2.6 & 2.6 & 3.00 & 2.74 \\
\hline $\begin{array}{c}\text { Particle Size, } \\
\text { microns }\end{array}$ & \multicolumn{9}{|c|}{ Cumulative Percent Finer Than } \\
\hline 6350 & 100 & 100 & 100 & 100 & 100 & 100 & 100 & 100 & 100 \\
\hline 4000 & 95.24 & 100 & 100 & 100 & 100 & 90 & 100 & 99 & 99 \\
\hline 1410 & 90 & 100 & 0 & 100 & 100 & 6 & 100 & 82 & 86 \\
\hline 500 & 36.67 & 100 & 0 & 100 & 100 & 0 & 84 & 77 & 79 \\
\hline 250 & 0 & 100 & 0 & 100 & 100 & 0 & 38 & 65 & 67 \\
\hline 100 & 0 & 100 & 0 & 98 & 100 & 0 & 2 & 57 & 65 \\
\hline 50 & 0 & 99 & 0 & 93 & 99 & 0 & 0 & 55 & 58 \\
\hline 40 & 0 & 97 & 0 & 80 & 92 & 0 & 0 & 51 & 56 \\
\hline 30 & 0 & 94 & 0 & 73 & 94 & 0 & 0 & 51 & 50 \\
\hline 20 & 0 & 91 & 0 & 66 & 97 & 0 & 0 & 50 & 43 \\
\hline 10 & 0 & 73 & 0 & 42 & 32 & 0 & 0 & 24 & 28 \\
\hline 5 & 0 & 57 & 0 & 24 & 6 & 0 & 0 & 12 & 17 \\
\hline 1 & 0 & 37 & 0 & 4 & 0 & 0 & 0 & 5 & 3 \\
\hline $\begin{array}{ll}d 90 \\
\end{array}$ & 1410 & 19 & 2706 & 47 & 19 & 4000 & 562 & 2560 & 2207 \\
\hline d50 & 600 & 4 & 2329 & 13 & 13 & 2800 & 295 & 20 & 31 \\
\hline d10 & 300 & 0 & 1875 & 2 & 6 & 2000 & 166 & 4 & 3 \\
\hline
\end{tabular}

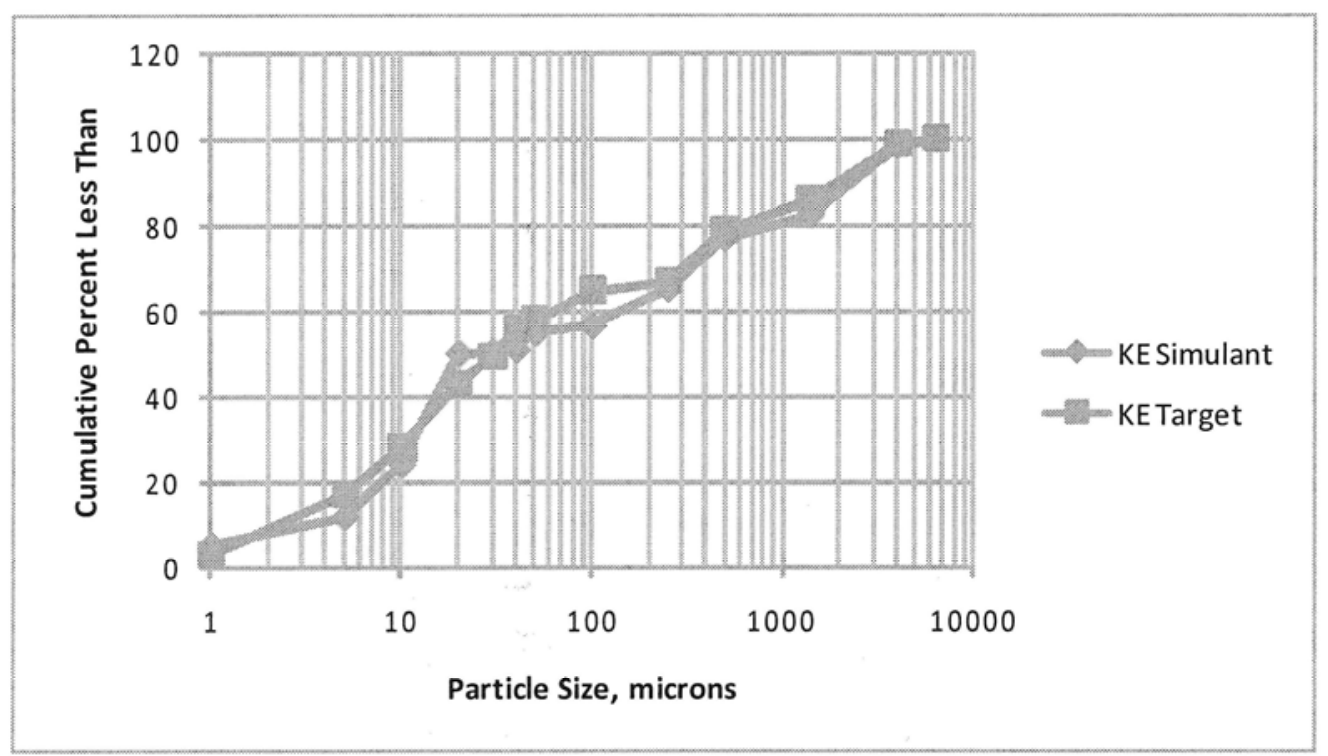


KW Basin Container Sludge Simulant (based on mixture of all KW floor sludge and pit sludge sources)

\begin{tabular}{|c|c|c|}
\hline Material & Amount, wt. \% & Particle Size Specification \\
\hline $\mathrm{CeO}_{2}$ or equivalent & 30.9 & $\mathrm{~d}_{10}=<1 \mu \mathrm{m}, \mathrm{d}_{50}=4 \mu \mathrm{m}, \mathrm{d}_{90}=19 \mu \mathrm{m}$ \\
\hline $\mathrm{FeOOH}$ or $\mathrm{Fe}(\mathrm{OH})_{3}$ & 21.9 & $\mathrm{~d}_{10}=6 \mu \mathrm{m}, \mathrm{d}_{50}=13 \mu \mathrm{m}, \mathrm{d}_{90}=19 \mu \mathrm{m}$ \\
\hline Sand & 14.7 & $\mathrm{~d}_{10}=.17 \mathrm{~mm}, \mathrm{~d}_{50}=.30 \mathrm{~mm}, \mathrm{~d}_{90}=.56 \mathrm{~mm}$ \\
\hline Aggregate & 16.9 & $\mathrm{~d}_{10}=1.3 \mathrm{~mm}, \mathrm{~d}_{50}=2.2 \mathrm{~mm}, \mathrm{~d}_{90}=3.7 \mathrm{~mm}$ \\
\hline Al(OH) $)_{3}$ & 7.8 & $\mathrm{~d}_{10}=2 \mu \mathrm{m}, \mathrm{d}_{50}=13 \mu \mathrm{m}, \mathrm{d}_{90}=47 \mu \mathrm{m}$ \\
\hline Steel Grit or equivalent & 4.2 & $\mathrm{~d}_{10}=.18 \mathrm{~mm}, \mathrm{~d}_{50}=.39 \mathrm{~mm}, \mathrm{~d}_{90}=.50 \mathrm{~mm}$ \\
\hline Dense metal or alloy & 3.6 & $\mathrm{~d}_{10}=.41 \mathrm{~mm}, \mathrm{~d}_{50}=1.8 \mathrm{~mm}, \mathrm{~d}_{90}=4.4 \mathrm{~mm}$ \\
\hline Total & 100.0 & $\mathrm{~d}_{10}=1 \mu \mathrm{m}, \mathrm{d}_{50}=17 \mu \mathrm{m}, \mathrm{d}_{90}=2.2 \mathrm{~mm}$ \\
\hline
\end{tabular}

Settler Sludge Simulant (\#1 - retrieval simulant)

\begin{tabular}{|c|c|c|}
\hline Material & Amount, wt. \% & Particle Size Specification \\
\hline $\mathrm{CeO}_{2}$ or equivalent & 68 & $\mathrm{~d}_{10}=.3 \mu \mathrm{m}, \mathrm{d}_{50}=4 \mu \mathrm{m}, \mathrm{d}_{90}=19 \mu \mathrm{m}$ \\
\hline Steel Grit or equivalent & 14 & $\mathrm{~d}_{10}=.10 \mathrm{~mm}, \mathrm{~d}_{50}=.34 \mathrm{~mm}, \mathrm{~d}_{90}=.53 \mathrm{~mm}$ \\
\hline Fly Ash & 11 & $\mathrm{~d}_{10}=1.4 \mu \mathrm{m}, \mathrm{d}_{50}=12 \mu \mathrm{m}, \mathrm{d}_{90}=96 \mu \mathrm{m}$ \\
\hline Dense metal or alloy & 6 & $\mathrm{~d}_{10}=.28 \mathrm{~mm}, \mathrm{~d}_{50}=.40 \mathrm{~mm}, \mathrm{~d}_{90}=.53 \mathrm{~mm}$ \\
\hline $\mathrm{Fe}(\mathrm{OH})_{3}$ & 1 & $\mathrm{~d}_{10}=.2 \mu \mathrm{m}, \mathrm{d}_{50}=.6 \mu \mathrm{m}, \mathrm{d}_{90}=1.0 \mu \mathrm{m}$ \\
\hline Total & 100.0 & $\mathrm{~d}_{10}=.10 \mathrm{~mm}, \mathrm{~d}_{50}=.34 \mathrm{~mm}, \mathrm{~d}_{90}=1.0 \mathrm{~mm}$ \\
\hline
\end{tabular}




\begin{tabular}{|c|c|c|c|c|c|c|c|c|c|}
\hline 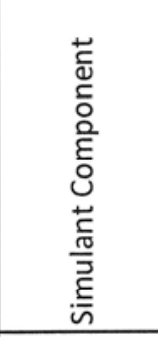 & 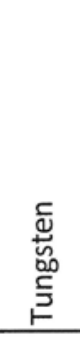 & 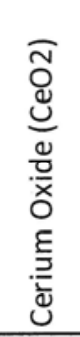 & 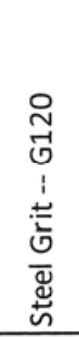 & 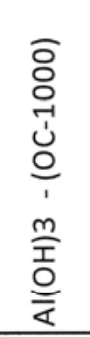 & 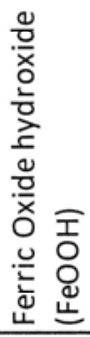 & 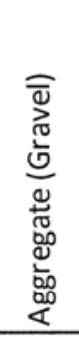 & 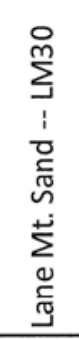 & 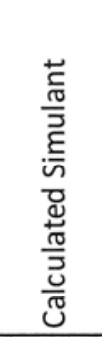 & 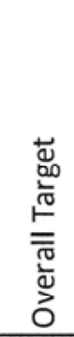 \\
\hline Wt. \%, dry & 3.6 & 30.9 & 4.2 & 7.8 & 21.9 & 16.9 & 14.7 & 100.0 & \\
\hline $\begin{array}{c}\text { Particle } \\
\text { Density, } \\
\mathrm{g} / \mathrm{cm}^{3}\end{array}$ & 16.9 & 7.13 & 7.86 & 2.42 & 2.85 & 2.6 & 2.6 & 3.55 & 3.29 \\
\hline & \multicolumn{9}{|c|}{ Particle Size Distribution, Cumulative Percent Less Than } \\
\hline 6350 & 100 & 100 & 100 & 100 & 100 & 100 & 100 & 100 & 100 \\
\hline 4000 & 88 & 100 & 100 & 100 & 100 & 98 & 100 & 99 & 99 \\
\hline 1410 & 44 & 100 & 100 & 100 & 100 & 31 & 100 & 86 & 86 \\
\hline 500 & 15 & 100 & 90 & 100 & 100 & 0 & 84 & 77 & 79 \\
\hline 250 & 0 & 100 & 16 & 100 & 100 & 0 & 38 & 67 & 69 \\
\hline 100 & 0 & 100 & 0 & 98 & 100 & 0 & 2 & 61 & 67 \\
\hline 50 & 0 & 99 & 0 & 93 & 99 & 0 & 0 & 60 & 60 \\
\hline 40 & 0 & 97 & 0 & 80 & 92 & 0 & 0 & 56 & 59 \\
\hline 20 & 0 & 91 & 0 & 66 & 97 & 0 & 0 & 55 & 45 \\
\hline 10 & 0 & 73 & 0 & 42 & 32 & 0 & 0 & 33 & 31 \\
\hline 5 & 0 & 57 & 0 & 24 & 6 & 0 & 0 & 21 & 19 \\
\hline 1 & 0 & 37 & 0 & 4 & 0 & 0 & 0 & 12 & 6 \\
\hline
\end{tabular}

\begin{tabular}{|r|r|r|r|r|r|r|r|r|r|}
\hline $\mathrm{d} 90$ & 4424 & 19 & 500 & 47 & 19 & 3700 & 562 & 2176 & 2207 \\
\hline $\mathrm{d} 50$ & 1780 & 4 & 386 & 13 & 13 & 2186 & 295 & 18 & 27 \\
\hline $\mathrm{d} 10$ & 409 & 0 & 180 & 2 & 6 & 1255 & 166 & 1 & 2 \\
\hline
\end{tabular}

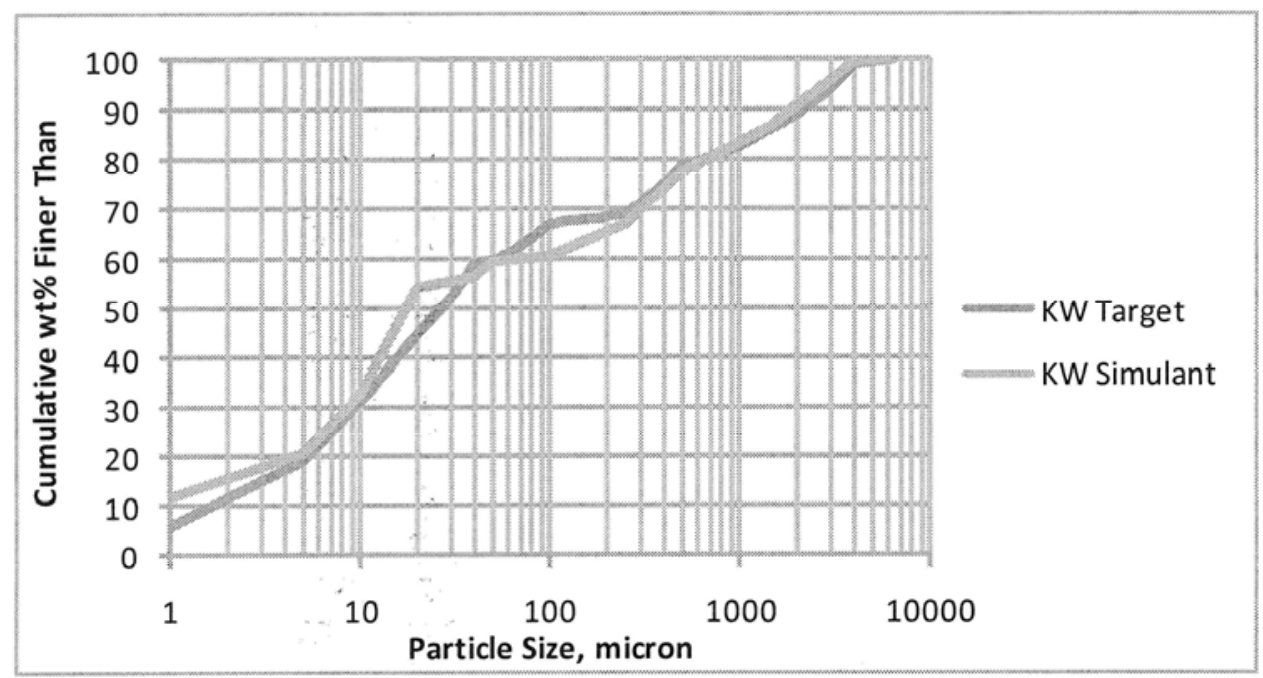




\begin{tabular}{|c|c|c|c|c|c|c|}
\hline 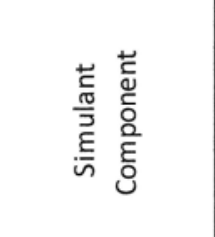 & 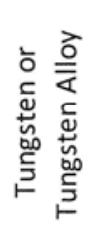 & 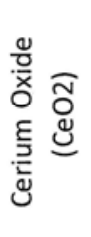 & $\begin{array}{l}\frac{c}{n} \\
\ll \\
\frac{\pi}{u} \\
u \\
u \\
\tilde{n} \\
\frac{\pi}{U}\end{array}$ & 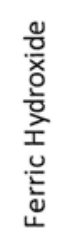 & 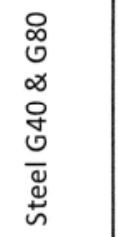 & $\begin{array}{l}\stackrel{+}{c} \\
\frac{\pi}{J} \\
\frac{E}{n}\end{array}$ \\
\hline Wt. \%, dry & 6 & 68 & 11 & 1 & 14 & 100.00 \\
\hline $\begin{array}{c}\text { Particle } \\
\text { Density, } \mathrm{g} / \mathrm{cm}^{3}\end{array}$ & 16.9 & 7.13 & 2.35 & 2.85 & 7.86 & 5.99 \\
\hline $\begin{array}{c}\text { Particle Size, } \\
\text { microns }\end{array}$ & \multicolumn{6}{|c|}{ Cumulative Percent Finer Than } \\
\hline 600 & 100 & 100 & 100 & 100 & 100 & 100 \\
\hline 500 & 85 & 100 & 100 & 100 & 85 & 97 \\
\hline 250 & 0 & 100 & 100 & 100 & 29 & 84 \\
\hline 100 & 0 & 100 & 97 & 100 & 0 & 80 \\
\hline 40 & 0 & 97 & 81 & 100 & 0 & 76 \\
\hline 20 & 0 & 91 & 65 & 100 & 0 & 70 \\
\hline 10 & 0 & 73 & 46 & 100 & 0 & 56 \\
\hline 5 & 0 & 57 & 30 & 100 & 0 & 43 \\
\hline 1 & 0 & 37 & 8 & 93 & 0 & 27 \\
\hline 0.1 & 0 & 0. & 0 & 0 & 0 & 0 \\
\hline
\end{tabular}

\begin{tabular}{|c|c|c|c|c|c|c|}
\hline $\mathrm{d} 90$ & 533 & 19 & 96 & 0.97 & 533 & \\
\hline $\mathrm{d} 50$ & 397 & 4 & 12 & 0.58 & 344 & \\
\hline $\mathrm{d} 10$ & 279 & 0.34 & 1.4 & 0.20 & 101 & \\
\hline
\end{tabular}

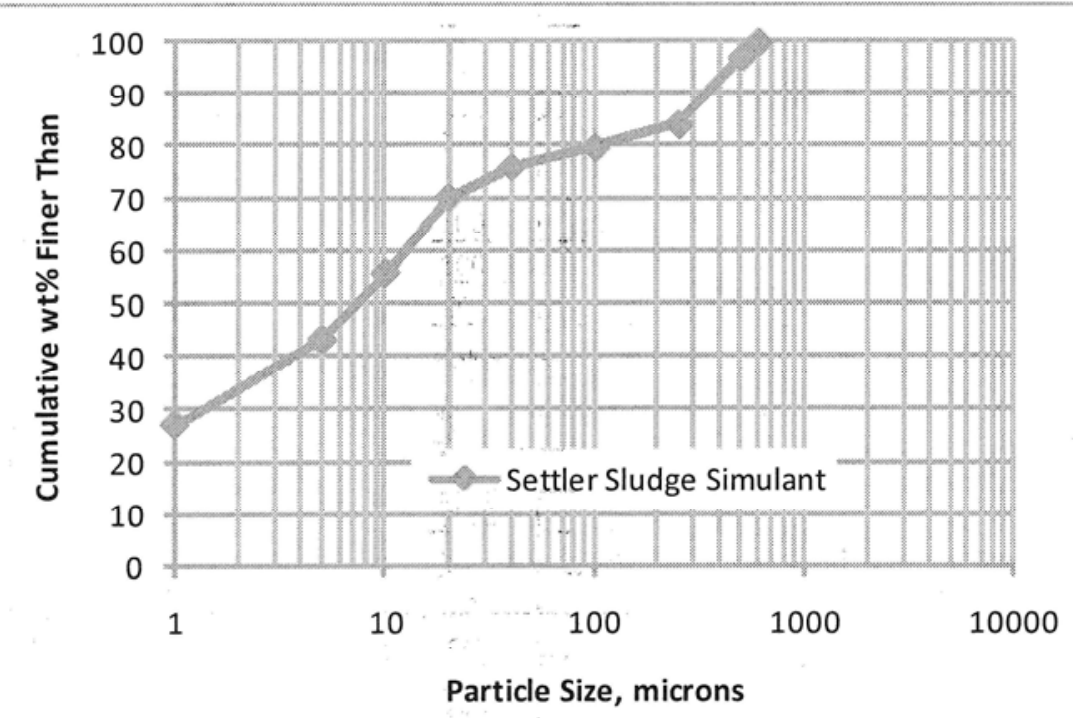


Sand represents quartz, zeolite, aluminosilicates, and other materials of similar density and particle size in the sludge. Preferably the sand should be actual Hanford blow sand obtained from drifts on site, but similar commercial sands can be used. Aggregate represents larger materials such as small rocks, concrete pieces, large corrosion products, etc. The aluminum hydroxide and ferric oxide-hydroxides represent the same compounds in the sludge that resulted from corrosion of the steel racks, aluminum cladding, etc. The dense metal is a substitute for uranium metal; tungsten metal is preferred, but other high-density $(>$ s.g. $=14)$ metals or alloys can be used, based on the specific test objectives.

Cerium oxide is a substitute for either all uranium oxides and hydroxides, or for just the less dense hydrated species $\left(\mathrm{UO}_{3} \cdot \mathrm{xH}_{2} \mathrm{O}\right)$. The steel grit is a substitute for $\mathrm{UO}_{2}$ and $\mathrm{U}_{4} \mathrm{O}_{9}$. $\mathrm{Bi}_{2} \mathrm{O}_{3}$, bismuth metal, or other materials having a higher specific gravity than steel and available in larger particle sizes than $\mathrm{CeO}_{2}$ may be substituted to represent $\mathrm{UO}_{2}$ and $\mathrm{U}_{4} \mathrm{O}_{9}$. None of these other materials are included in the recipes above because $\mathrm{UO}_{2}$ is not a limiting species - the uranium in actual sludge is more dense and larger in particle size than the oxides, and sand is equally or more abrasive than $\mathrm{UO}_{2}$.

The particles size specifications are the desired, but due to the large range and uncertainty in the actual sludge properties and variability in commercial products, variation in the specifications of up to about $50 \%$ are acceptable for individual ingredients, and about $20 \%$ for the overall particle sizes. The recipes above do not include ion exchange beads, but these can be added if important for certain tests. Other variations may be appropriate as determined on a case-by-case basis.

A words of caution: When a simulated waste is made with the above recipe, the settled sludge density is often considerably higher that measured in actual sludge - it compacts substantially more. This is probably because the $\mathrm{FeOOH}$ and $\mathrm{CeO}_{2}$ (which are dry powders) do not hydrate or attract and carry around water molecules like the wet iron oxide-hydroxides and $\mathrm{UO}_{3} \cdot \mathrm{xH}_{2} \mathrm{O}$ compounds do in the real sludge, making it less compressible.

Concurrence:

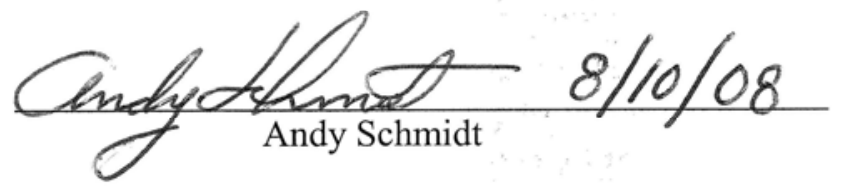




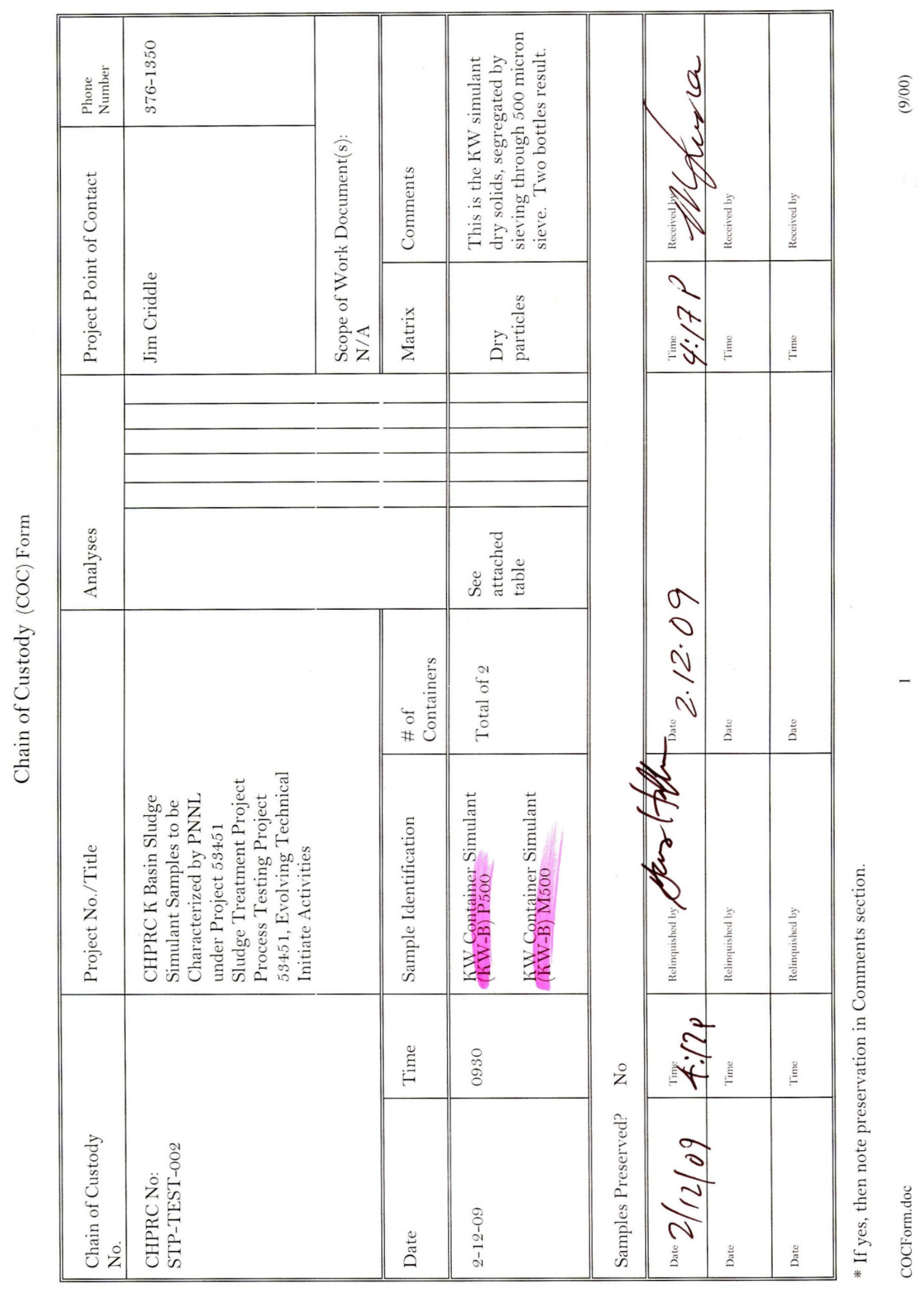


Characterization Approach for Simulant Confirmation

Attachment to CoC-1

\begin{tabular}{|c|c|c|}
\hline Property/Parameter & $\begin{array}{l}\text { Measurement/Calculation } \\
\text { Approach }\end{array}$ & Frequency \\
\hline Settled Density & $\begin{array}{l}\text { Prep simulant with excess water, allow } \\
\text { sludge to settle for } 24 \mathrm{hr} \text {, measure volume } \\
\text { and mass. }\end{array}$ & Routine $^{(a)}$ \\
\hline $\begin{array}{l}\text { Wt \% Solids } \\
\text { (in settled sludge) }\end{array}$ & $\begin{array}{l}\text { Dry aliquot (known mass and volume) of } \\
\text { as-settled sludge at } 105^{\circ} \mathrm{C} \text {, measure mass, } \\
\text { and record dry bulk volume. }\end{array}$ & Routine $^{(a)}$ \\
\hline $\begin{array}{l}\text { Volume Fraction Water } \\
\text { (in settled sludge) }\end{array}$ & $\begin{array}{l}\text { Calculated from settled density and } w t \% \\
\text { solids. Assumption: all mass loss during } \\
\text { drying at } 105^{\circ} \mathrm{C} \text { is from loss of water }\end{array}$ & Routine $^{(a)}$ \\
\hline $\begin{array}{l}\text { Volume Fraction Solids } \\
\text { (in settled sludge) }\end{array}$ & Calculated from Volume Fraction Water & Routine $^{(a)}$ \\
\hline Settling Rate & Graduated cylinder and stop watch & Routine $^{(a)}$ \\
\hline \multirow{3}{*}{ Average Particle Density } & $\begin{array}{l}\text { Calculated from } \mathrm{Wt} \% \text { solids and } \mathrm{Vol} \\
\text { fraction solids }\end{array}$ & Routine $^{(a)}$ \\
\hline & $\begin{array}{l}\text { Calculated from vendor/handbook data } \\
\text { on simulant components and simulant } \\
\text { make up }\end{array}$ & Routine $^{(a)}$ \\
\hline & $\begin{array}{l}\text { Representative dry sample, density via } \\
\text { pycnometry }\end{array}$ & $\begin{array}{l}\text { As needed }{ }^{(b)} \text {, can be used to } \\
\text { confirm individual } \\
\text { components }\end{array}$ \\
\hline \multirow{3}{*}{ Particle Size Distribution } & $\begin{array}{l}\text { Calculated from vendor data on } \\
\text { components and simulant make up }\end{array}$ & Routine $^{(a)}$ \\
\hline & $<500 \mu \mathrm{m}$ - Particle size analyzer & Routine $^{(a)}$ \\
\hline & $\begin{array}{l}\text { Sieve full sample using the following } \\
\text { Sieves: } 2000 \mu \mathrm{m} \text { and } 500 \mu \mathrm{m}-\text { dry mass } \\
\text { of resulting three fraction }\end{array}$ & Routine $^{(a)}$ \\
\hline $\begin{array}{l}\text { Viscosity vs Shear Rate } \\
\text { Shear Stress vs. Shear Rate } \\
\text { (Rheograms) }\end{array}$ & $\begin{array}{l}<500 \mu \mathrm{m} \text { fraction: } \\
\text { Concentrations: as settled, } 75 \%, 50 \% \text { and } \\
25 \% \text { volume ratio of as settled + water.. } \\
\text { Rheology of Each concentration will be } \\
\text { measured at } 55^{\circ} \mathrm{F} \text { and } 72^{\circ} \mathrm{F}\end{array}$ & Routine $^{(\mathrm{a})(\mathrm{c})}$ \\
\hline Shear strength & $\begin{array}{l}<500 \mu \mathrm{m} \text { fraction: } \\
\text { Settled sludge ( } 48 \text { to } 72 \text { hour gel time, } \\
\text { vane rheometer }\end{array}$ & Routine $^{(a)}$ \\
\hline \multicolumn{3}{|c|}{$\begin{array}{l}\text { (a) Routine - Recommend base characterization for all simulants. Significant data from actual sludge } \\
\text { exists for comparison. } \\
\text { (b) As needed - based on testing objectives for specific simulant, (note part of scope). } \\
\text { (c) There is a limited set of rheograms from actual sludge to compare to rheograms from simulants }\end{array}$} \\
\hline
\end{tabular}


KW Simulant Sample Batch - Segregated (KW-B)

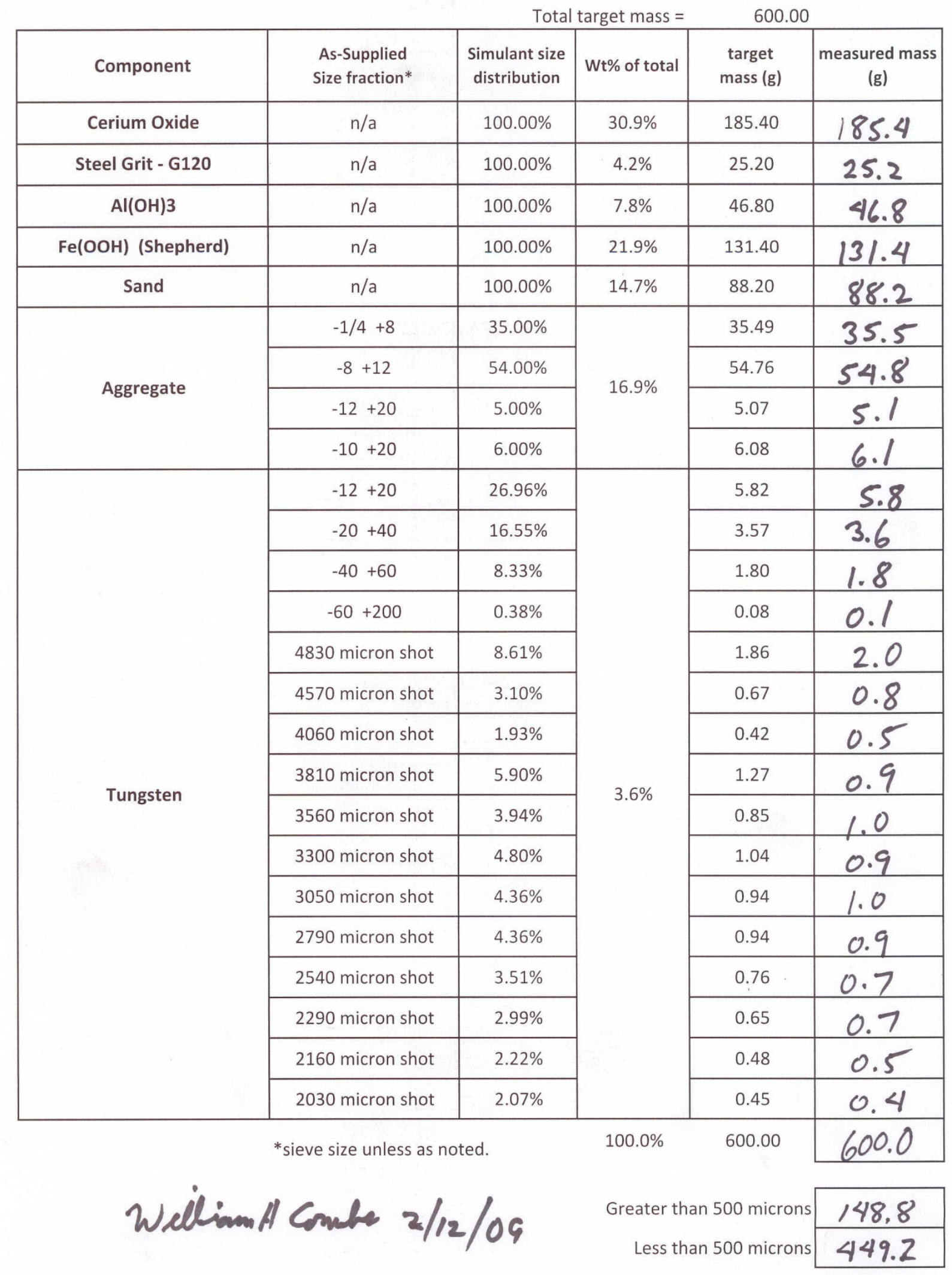

A. 10 


\begin{tabular}{|c|c|c|c|c|c|c|c|c|c|c|c|c|c|c|}
\hline 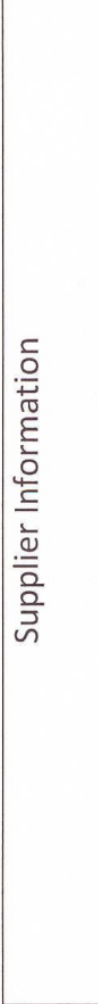 & 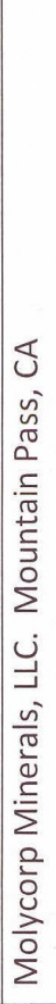 & 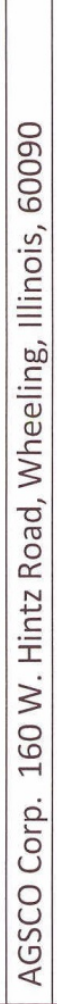 & 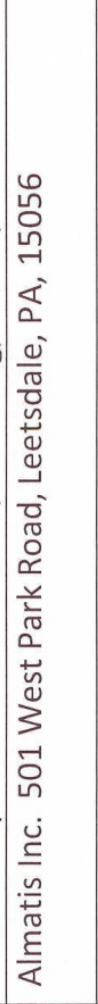 & 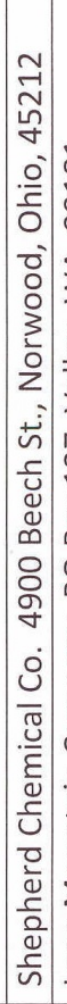 & 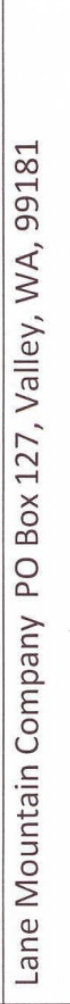 & 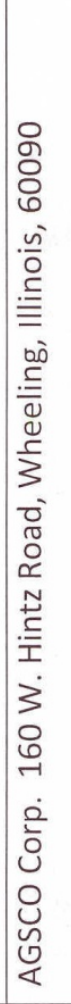 & 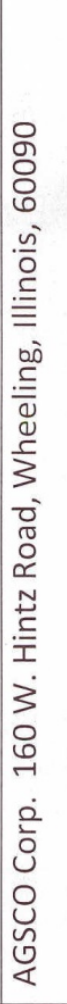 & 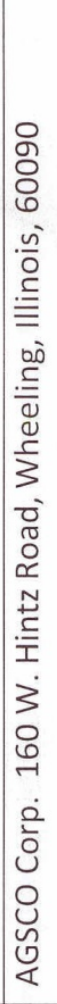 & 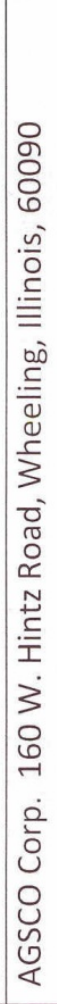 & 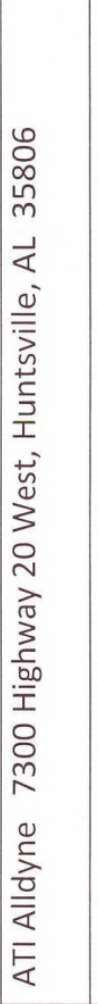 & 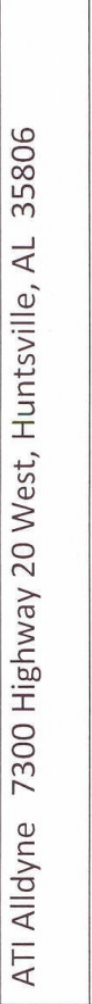 & 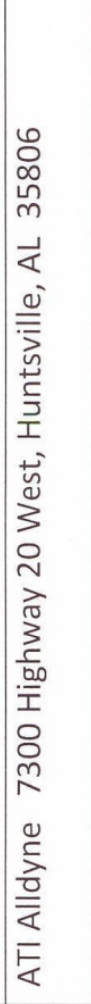 & 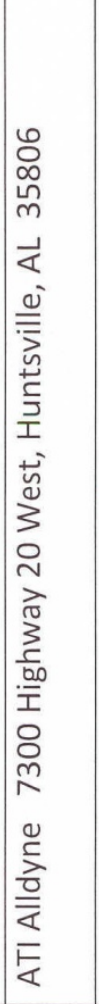 & 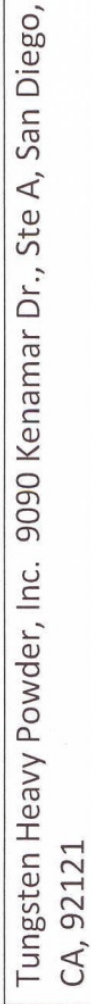 \\
\hline 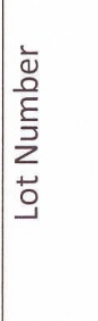 & 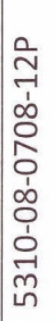 & 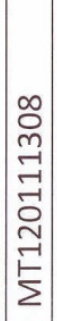 & 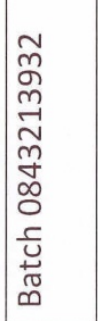 & 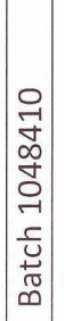 & 元 & 吕 & $\begin{array}{l}\infty \\
0 \\
0 \\
\mathbb{1} \\
0 \\
0\end{array}$ & $\begin{array}{l}\infty \\
\text { Oे } \\
\text { సે } \\
\text { o }\end{array}$ & $\begin{array}{l}\infty \\
\text { Оి } \\
\text { ำ }\end{array}$ & 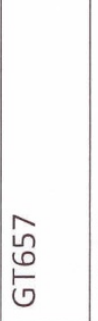 & 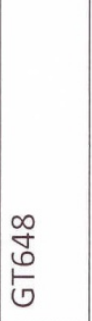 & 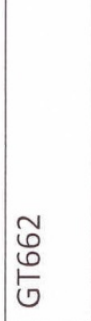 & 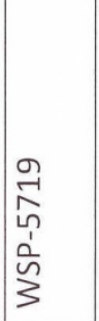 & 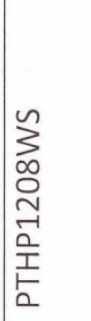 \\
\hline 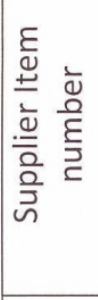 & 오 & 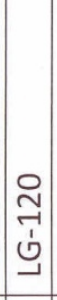 & 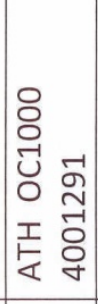 & 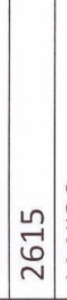 & $\begin{array}{l}0 \\
⿱ 亠 凶 \\
⿱ \# \\
⿱ 亠 䒑\end{array}$ & 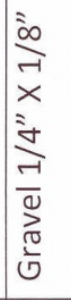 & 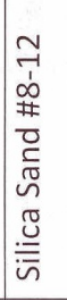 & 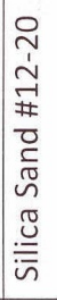 & 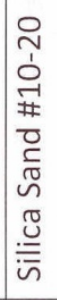 & $\begin{array}{l}m \\
0 \\
\infty \\
\infty \\
0\end{array}$ & $\begin{array}{l}m \\
\stackrel{m}{1} \\
\infty \\
\infty \\
0\end{array}$ & $\begin{array}{l}+ \\
\stackrel{1}{2} \\
\stackrel{2}{\infty} \\
\infty \\
\infty\end{array}$ & $\begin{array}{l}\overrightarrow{1} \\
\vec{b} \\
0\end{array}$ & 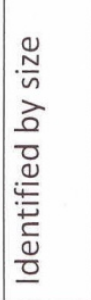 \\
\hline 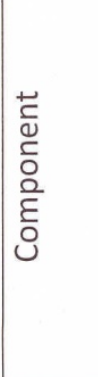 & 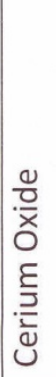 & 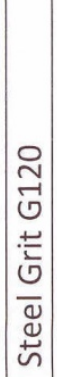 & $\frac{m}{\frac{m}{\underline{x}}}$ & 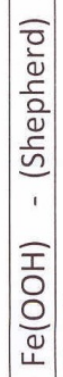 & $\begin{array}{l}\bar{D} \\
\text { 足 } \\
\text { N }\end{array}$ & 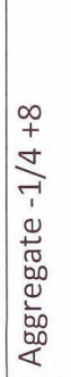 & 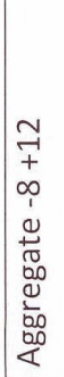 & 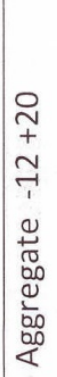 & \begin{tabular}{l}
0 \\
\multirow{1}{*}{} \\
+ \\
0 \\
7 \\
1 \\
0 \\
0 \\
0 \\
0 \\
0 \\
0 \\
0 \\
00 \\
00 \\
$\alpha$
\end{tabular} & 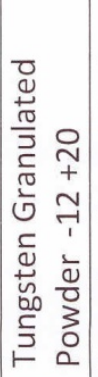 & 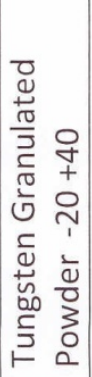 & 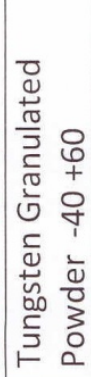 & 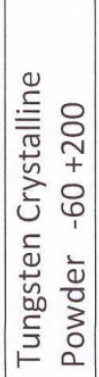 & 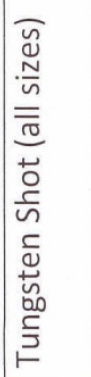 \\
\hline
\end{tabular}




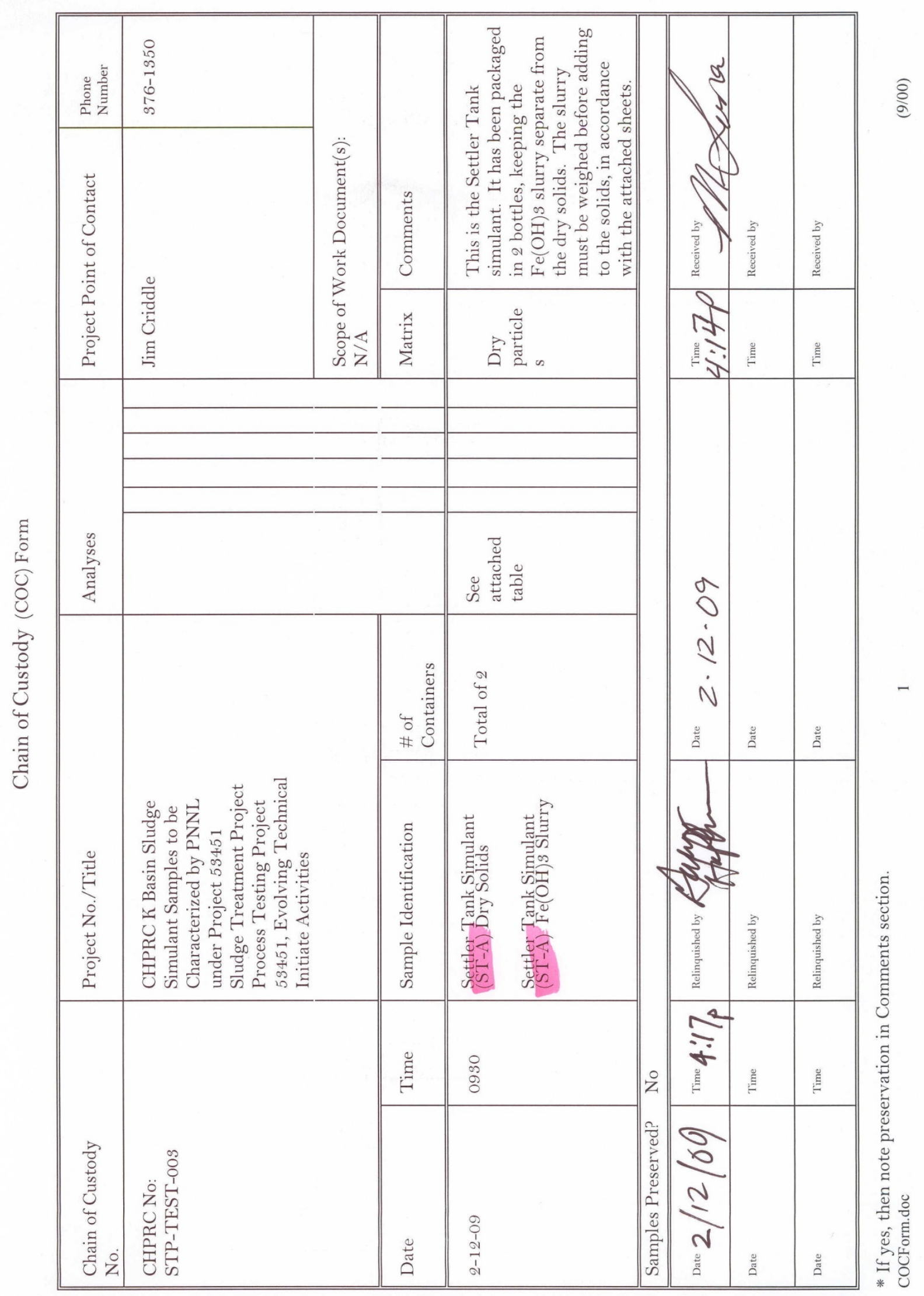

A. 12 


\section{Characterization Approach for Simulant Confirmation}

Attachment to CoC-1

\begin{tabular}{|c|c|c|}
\hline Property/Parameter & $\begin{array}{c}\text { Measurement/Calculation } \\
\text { Approach }\end{array}$ & Frequency \\
\hline Settled Density & $\begin{array}{l}\text { Prep simulant with excess water, allow } \\
\text { sludge to settle for } 24 \mathrm{hr} \text {, measure volume } \\
\text { and mass. }\end{array}$ & Routine $^{(a)}$ \\
\hline $\begin{array}{l}\text { Wt \% Solids } \\
\text { (in settled sludge) }\end{array}$ & $\begin{array}{l}\text { Dry aliquot (known mass and volume) of } \\
\text { as-settled sludge at } 105^{\circ} \mathrm{C} \text {, measure mass, } \\
\text { and record dry bulk volume. }\end{array}$ & Routine $^{(a)}$ \\
\hline $\begin{array}{l}\text { Volume Fraction Water } \\
\text { (in settled sludge) }\end{array}$ & $\begin{array}{l}\text { Calculated from settled density and } w t \% \\
\text { solids. Assumption: all mass loss during } \\
\text { drying at } 105^{\circ} \mathrm{C} \text { is from loss of water }\end{array}$ & Routine $^{(a)}$ \\
\hline $\begin{array}{l}\text { Volume Fraction Solids } \\
\text { (in settled sludge) }\end{array}$ & Calculated from Volume Fraction Water & Routine $^{(a)}$ \\
\hline Settling Rate & Graduated cylinder and stop watch & Routine $^{(a)}$ \\
\hline \multirow{3}{*}{ Average Particle Density } & $\begin{array}{l}\text { Calculated from } \mathrm{Wt} \% \text { solids and } \mathrm{Vol} \\
\text { fraction solids }\end{array}$ & Routine $^{(a)}$ \\
\hline & $\begin{array}{c}\text { Calculated from vendor/handbook data } \\
\text { on simulant components and simulant } \\
\text { make up }\end{array}$ & Routine $^{(a)}$ \\
\hline & $\begin{array}{l}\text { Representative dry sample, density via } \\
\text { pycnometry }\end{array}$ & $\begin{array}{l}\text { As needed }{ }^{(b)} \text {, can be used to } \\
\text { confirm individual } \\
\text { components }\end{array}$ \\
\hline \multirow{3}{*}{ Particle Size Distribution } & $\begin{array}{l}\text { Calculated from vendor data on } \\
\text { components and simulant make up }\end{array}$ & Routine $^{(a)}$ \\
\hline & $<500 \mu \mathrm{m}$ - Particle size analyzer & Routine $^{(a)}$ \\
\hline & $\begin{array}{l}\text { Sieve full sample using the following } \\
\text { Sieves: } 2000 \mu \mathrm{m} \text { and } 500 \mu \mathrm{m}-\text { dry mass } \\
\text { of resulting three fraction }\end{array}$ & Routine $^{(a)}$ \\
\hline $\begin{array}{l}\text { Viscosity vs Shear Rate } \\
\text { Shear Stress vs. Shear Rate } \\
\text { (Rheograms) }\end{array}$ & $\begin{array}{l}<500 \mu \mathrm{m} \text { fraction: } \\
\text { Concentrations: as settled, } 75 \%, 50 \% \text { and } \\
25 \% \text { volume ratio of as settled }+ \text { water.. } \\
\text { Rheology of Each concentration will be } \\
\text { measured at } 55^{\circ} \mathrm{F} \text { and } 72^{\circ} \mathrm{F}\end{array}$ & Routine $^{(\mathrm{a})(\mathrm{c})}$ \\
\hline Shear strength & $\begin{array}{l}<500 \mu \mathrm{m} \text { fraction: } \\
\text { Settled sludge ( } 48 \text { to } 72 \text { hour gel time, } \\
\text { vane rheometer }\end{array}$ & Routine $^{(a)}$ \\
\hline \multicolumn{3}{|c|}{$\begin{array}{l}\text { (a) Routine-Recommend base characterization for all simulants. Significant data from actual sludge } \\
\text { exists for comparison. } \\
\text { (b) As needed - based on testing objectives for specific simulant, (note part of scope). } \\
\text { (c) There is a limited set of rheograms from actual sludge to compare to rheograms from simulants }\end{array}$} \\
\hline
\end{tabular}




\section{Settler Simulant Sample Batch (ST-A)}

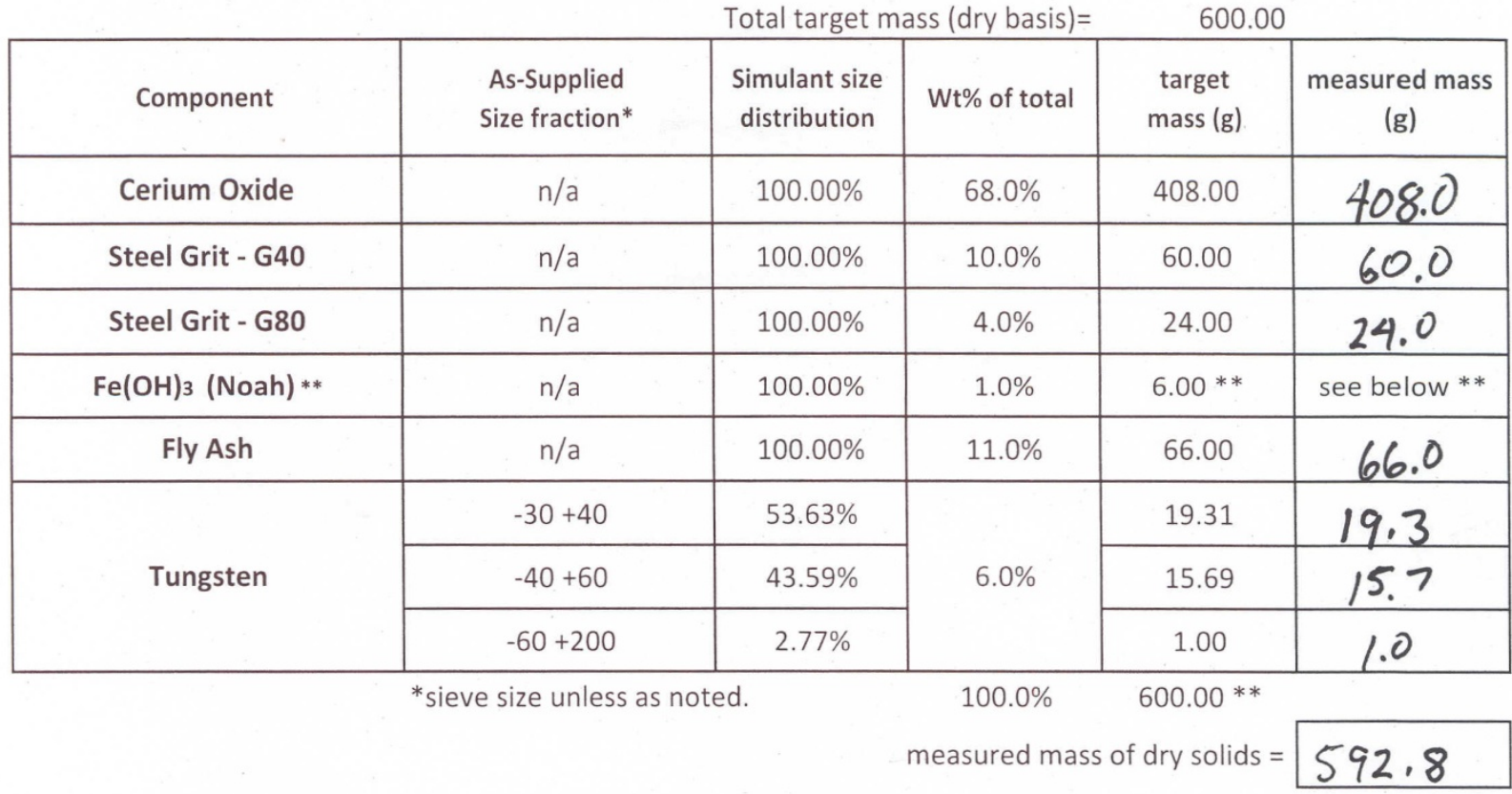

** This material comes in a slurry and will be kept separate from the dry solids.

It is advertiseds as $13 \%$ wt solids. To achieve the required 6 grams of solids, add ( $6.0 / .13=46.2$ grams) to the provided Dry solids to make the sample batch. NOTE... the supplied container will contain extra material to assist you in obtaining the correct amount... the container will have 70 grams. Discard unused portion.

$$
\begin{aligned}
& 70.0 \mathrm{gm} \\
& \text { Willinith Comber } \mathrm{r} / \mathrm{s} / \mathrm{og}
\end{aligned}
$$




\begin{tabular}{|c|c|c|c|c|c|c|c|c|}
\hline 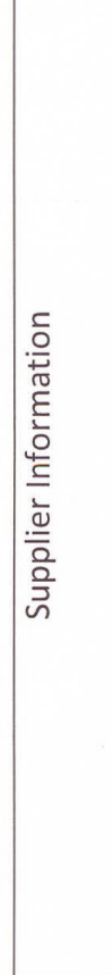 & 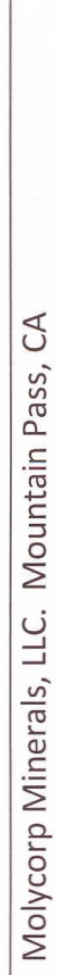 & 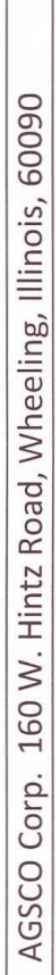 & 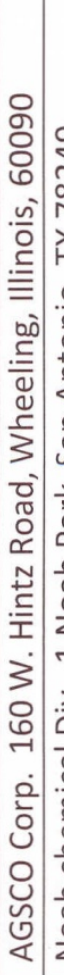 & 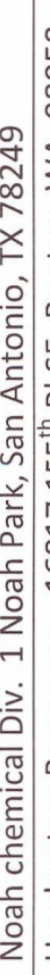 & 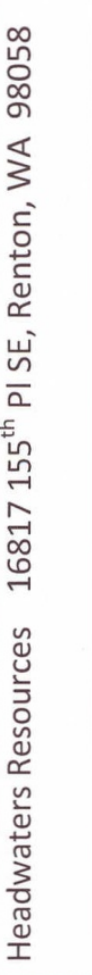 & 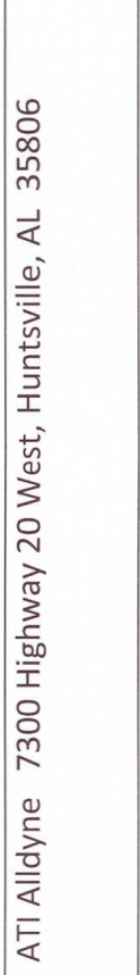 & 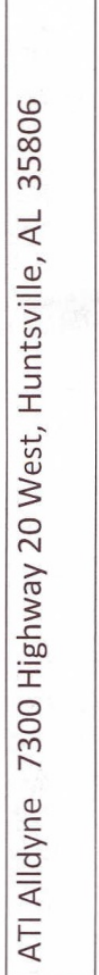 & 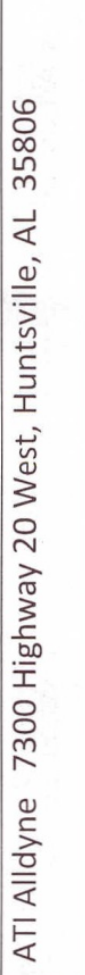 \\
\hline 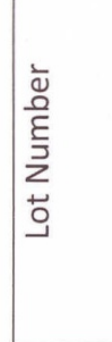 & \begin{tabular}{l} 
\\
\multirow{1}{*}{} \\
0 \\
0 \\
0 \\
0 \\
0 \\
0 \\
0 \\
0 \\
0 \\
$\tilde{1}$ \\
nn
\end{tabular} & 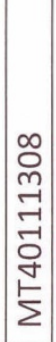 & 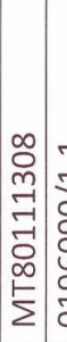 & $\begin{array}{c}-1 \\
- \\
- \\
8 \\
0 \\
0 \\
0 \\
0\end{array}$ & 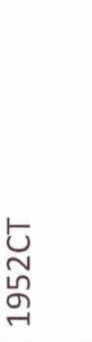 & \begin{tabular}{l}
$\infty$ \\
\multirow{\sigma}{*}{} \\
$ٍ$ \\
$\circlearrowleft$
\end{tabular} & 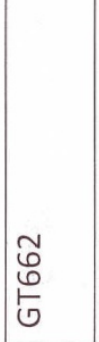 & 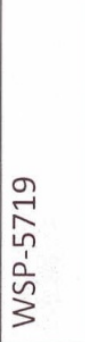 \\
\hline 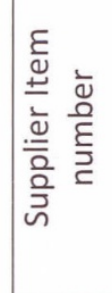 & 옴 & 움 & 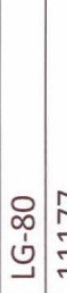 & $\begin{array}{l}\hat{N} \\
\stackrel{-}{G} \\
-\end{array}$ & 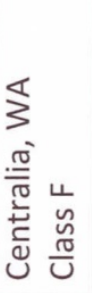 & $\begin{array}{l}m \\
\stackrel{1}{\circ} \\
\infty \\
\infty \\
\alpha\end{array}$ & 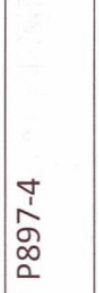 & $\begin{array}{l}\vec{J} \\
\vec{\emptyset} \\
\alpha\end{array}$ \\
\hline 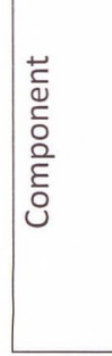 & 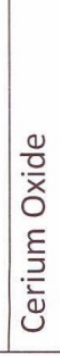 & 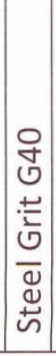 & 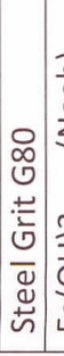 & 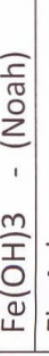 & $\begin{array}{l}\frac{5}{4} \\
\frac{1}{x} \\
\frac{\lambda}{4}\end{array}$ & 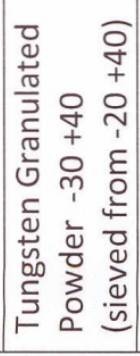 & 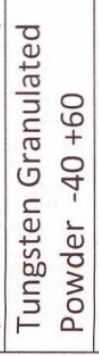 & 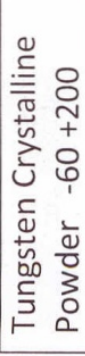 \\
\hline
\end{tabular}

A. 15 


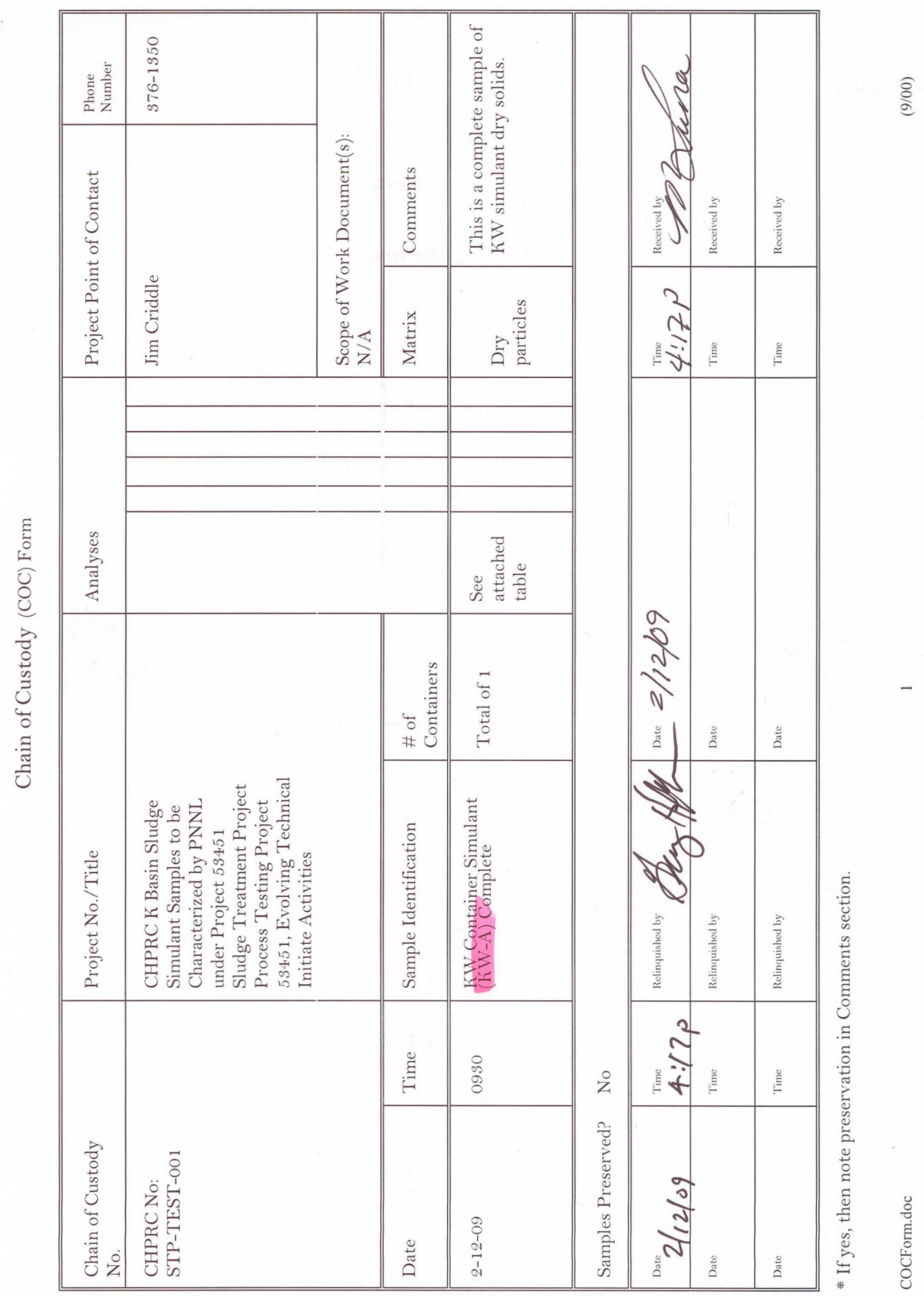

A. 16 
Characterization Approach for Simulant Confirmation

Attachment to $\mathrm{CoC}-1$

\begin{tabular}{|c|c|c|}
\hline Property/Parameter & $\begin{array}{c}\text { Measurement/Calculation } \\
\text { Approach }\end{array}$ & Frequency \\
\hline Settled Density & $\begin{array}{l}\text { Prep simulant with excess water, allow } \\
\text { sludge to settle for } 24 \mathrm{hr} \text {, measure volume } \\
\text { and mass. }\end{array}$ & Routine $^{(a)}$ \\
\hline $\begin{array}{l}\text { Wt \% Solids } \\
\text { (in settled sludge) }\end{array}$ & $\begin{array}{l}\text { Dry aliquot (known mass and volume) of } \\
\text { as-settled sludge at } 105^{\circ} \mathrm{C} \text {, measure mass, } \\
\text { and record dry bulk volume. }\end{array}$ & Routine $^{(a)}$ \\
\hline $\begin{array}{l}\text { Volume Fraction Water } \\
\text { (in settled sludge) }\end{array}$ & $\begin{array}{l}\text { Calculated from settled density and wt } \% \\
\text { solids. Assumption: all mass loss during } \\
\text { drying at } 105^{\circ} \mathrm{C} \text { is from loss of water }\end{array}$ & Routine $^{(a)}$ \\
\hline $\begin{array}{l}\text { Volume Fraction Solids } \\
\text { (in settled sludge) }\end{array}$ & Calculated from Volume Fraction Water & Routine $^{(a)}$ \\
\hline Settling Rate & Graduated cylinder and stop watch & Routine $^{(a)}$ \\
\hline \multirow{3}{*}{ Average Particle Density } & $\begin{array}{l}\text { Calculated from } \mathrm{W} \mathrm{t} \% \text { solids and } \mathrm{Vol} \\
\text { fraction solids }\end{array}$ & Routine $^{(a)}$ \\
\hline & $\begin{array}{l}\text { Calculated from vendor/handbook data } \\
\text { on simulant components and simulant } \\
\text { make up }\end{array}$ & Routine $^{(a)}$ \\
\hline & $\begin{array}{l}\text { Representative dry sample, density via } \\
\text { pycnometry }\end{array}$ & $\begin{array}{l}\text { As needed }{ }^{(b)}, \text { can be used to } \\
\text { confirm individual } \\
\text { components }\end{array}$ \\
\hline \multirow{3}{*}{ Particle Size Distribution } & $\begin{array}{l}\text { Calculated from vendor data on } \\
\text { components and simulant make up }\end{array}$ & Routine $^{(a)}$ \\
\hline & $<500 \mu \mathrm{m}$ - Particle size analyzer & Routine $^{(a)}$ \\
\hline & $\begin{array}{l}\text { Sieve full sample using the following } \\
\text { Sieves: } 2000 \mu \mathrm{m} \text { and } 500 \mu \mathrm{m}-\text { dry mass } \\
\text { of resulting three fraction }\end{array}$ & Routine $^{(\mathrm{a})}$ \\
\hline $\begin{array}{l}\text { Viscosity vs Shear Rate } \\
\text { Shear Stress vs. Shear Rate } \\
\text { (Rheograms) }\end{array}$ & $\begin{array}{l}<500 \mu \mathrm{m} \text { fraction: } \\
\text { Concentrations: as settled, } 75 \%, 50 \% \text { and } \\
25 \% \text { volume ratio of as settled }+ \text { water.. } \\
\text { Rheology of Each concentration will be } \\
\text { measured at } 55^{\circ} \mathrm{F} \text { and } 72^{\circ} \mathrm{F}\end{array}$ & Routine $^{(\mathrm{a})(\mathrm{c})}$ \\
\hline Shear strength & $\begin{array}{c}<500 \mu \mathrm{m} \text { fraction: } \\
\text { Settled sludge ( } 48 \text { to } 72 \text { hour gel time, } \\
\text { vane rheometer }\end{array}$ & Routine $^{(a)}$ \\
\hline \multicolumn{3}{|c|}{$\begin{array}{l}\text { (a) Routine - Recommend base characterization for all simulants. Significant data from actual sludge } \\
\text { exists for comparison. } \\
\text { (b) As needed - based on testing objectives for specific simulant, (note part of scope). } \\
\text { (c) There is a limited set of rheograms from actual sludge to compare to rheograms from simulants }\end{array}$} \\
\hline
\end{tabular}


KW Simulant Sample Batch - Not segregated (KW-A)

\begin{tabular}{|c|c|c|c|c|c|}
\hline & \multicolumn{3}{|c|}{ Total target mass $=$} & 600.00 & \multirow[b]{2}{*}{$\begin{array}{c}\text { measured mass } \\
\text { (g) }\end{array}$} \\
\hline Component & $\begin{array}{l}\text { As-Supplied } \\
\text { Size fraction* }\end{array}$ & $\begin{array}{l}\text { Simulant size } \\
\text { distribution }\end{array}$ & Wt\% of total & $\begin{array}{c}\text { target } \\
\text { mass (g) }\end{array}$ & \\
\hline Cerium Oxide & $\mathrm{n} / \mathrm{a}$ & $100.00 \%$ & $30.9 \%$ & 185.40 & 185.4 \\
\hline Steel Grit - G120 & $\mathrm{n} / \mathrm{a}$ & $100.00 \%$ & $4.2 \%$ & 25.20 & 25.2 \\
\hline $\mathrm{Al}(\mathrm{OH}) 3$ & $\mathrm{n} / \mathrm{a}$ & $100.00 \%$ & $7.8 \%$ & 46.80 & 46.8 \\
\hline $\mathrm{Fe}(\mathrm{OOH})$ (Shepherd) & $\mathrm{n} / \mathrm{a}$ & $100.00 \%$ & $21.9 \%$ & 131.40 & 131.4 \\
\hline Sand & $\mathrm{n} / \mathrm{a}$ & $100.00 \%$ & $14.7 \%$ & 88.20 & 88.2 \\
\hline \multirow{4}{*}{ Aggregate } & $-1 / 4+8$ & $35.00 \%$ & \multirow{4}{*}{$16.9 \%$} & 35.49 & 35.5 \\
\hline & $-8+12$ & $54.00 \%$ & & 54.76 & 54.8 \\
\hline & $-12+20$ & $5.00 \%$ & & 5.07 & 5.1 \\
\hline & $-10+20$ & $6.00 \%$ & & 6.08 & 6.1 \\
\hline \multirow{16}{*}{ Tungsten } & $-12+20$ & $26.96 \%$ & \multirow{16}{*}{$3.6 \%$} & 5.82 & 5.8 \\
\hline & $-20+40$ & $16.55 \%$ & & 3.57 & 3.6 \\
\hline & $-40+60$ & $8.33 \%$ & & 1.80 & 1.8 \\
\hline & $-60+200$ & $0.38 \%$ & & 0.08 & 0.1 \\
\hline & 4830 micron shot & $8.61 \%$ & & 1.86 & 2.0 \\
\hline & 4570 micron shot & $3.10 \%$ & & 0.67 & 0.8 \\
\hline & 4060 micron shot & $1.93 \%$ & & 0.42 & 0.5 \\
\hline & 3810 micron shot & $5.90 \%$ & & 1.27 & 0.9 \\
\hline & 3560 micron shot & $3.94 \%$ & & 0.85 & 1.0 \\
\hline & 3300 micron shot & $4.80 \%$ & & 1.04 & 0.9 \\
\hline & 3050 micron shot & $4.36 \%$ & & 0.94 & 1.0 \\
\hline & 2790 micron shot & $4.36 \%$ & & 0.94 & 0.9 \\
\hline & 2540 micron shot & $3.51 \%$ & & 0.76 & 0.7 \\
\hline & 2290 micron shot & $2.99 \%$ & & 0.65 & 0.7 \\
\hline & 2160 micron shot & $2.22 \%$ & & 0.48 & 0.5 \\
\hline & 2030 micron shot & $2.07 \%$ & & 0.45 & 0.4 \\
\hline \multicolumn{3}{|c|}{ *sieve size unless as noted. } & $100.0 \%$ & 600.00 & 600.0 \\
\hline
\end{tabular}




\begin{tabular}{|c|c|c|c|c|c|c|c|c|c|c|c|c|c|c|}
\hline 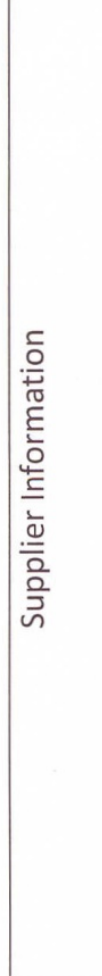 & 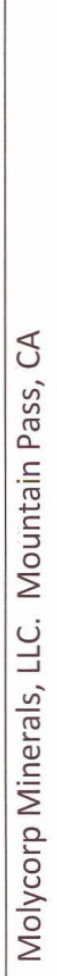 & 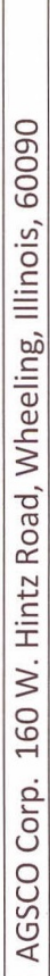 & 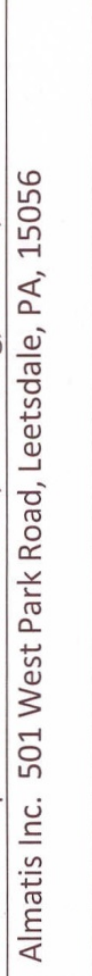 & 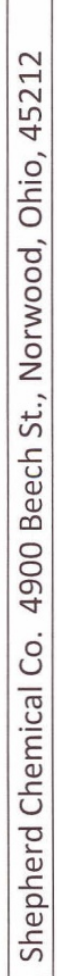 & 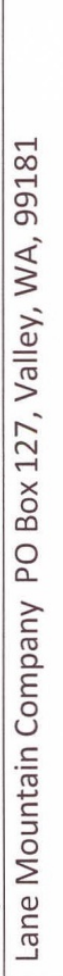 & 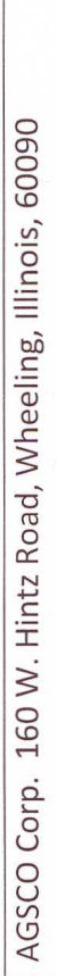 & 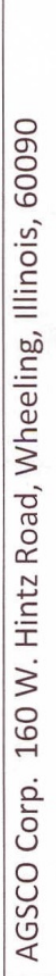 & 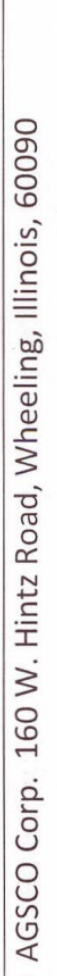 & 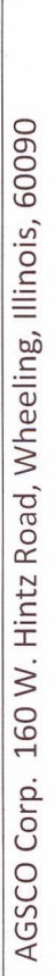 & 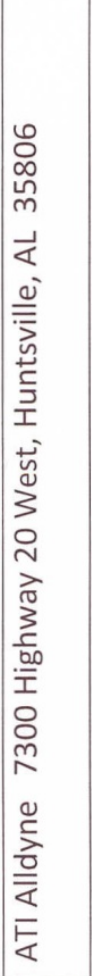 & 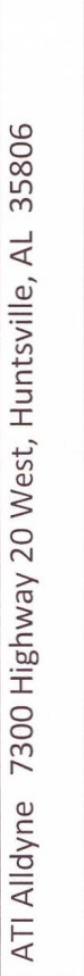 & 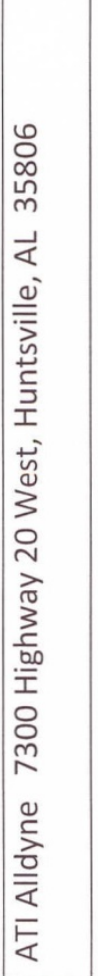 & 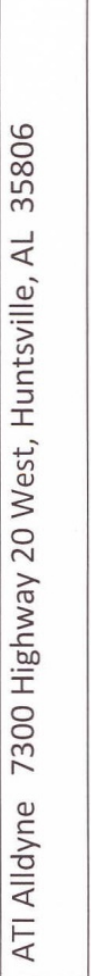 & 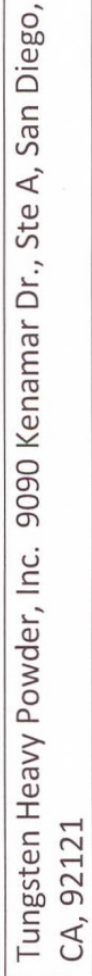 \\
\hline 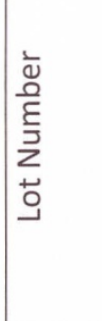 & 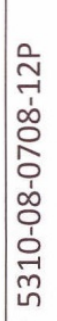 & 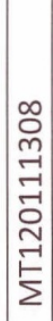 & 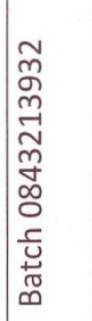 & 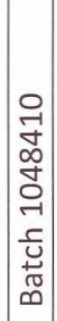 & 巳ั & 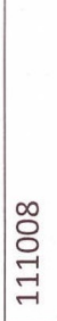 & 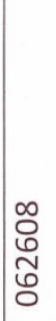 & $\begin{array}{l}\text { ஜ̊ } \\
\text { ઝે } \\
\text { જू }\end{array}$ & 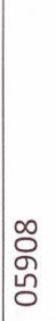 & 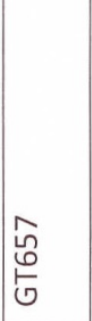 & 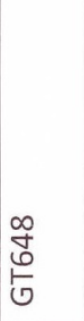 & 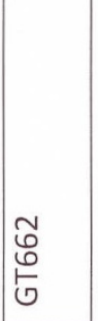 & 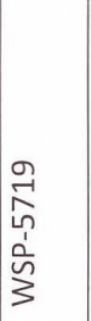 & 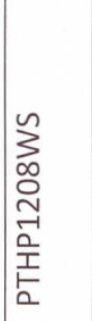 \\
\hline 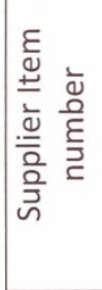 & 으 & 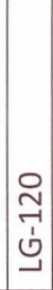 & 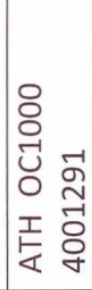 & $\begin{array}{l}n \\
\stackrel{n}{0} \\
\text { N }\end{array}$ & 兽 & 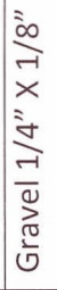 & 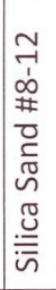 & 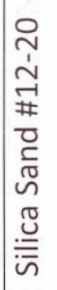 & 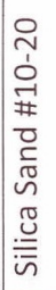 & $\begin{array}{l}m \\
\grave{2} \\
\infty \\
0 \\
0\end{array}$ & $\begin{array}{l}m \\
\stackrel{m}{1} \\
\stackrel{2}{0} \\
0\end{array}$ & $\begin{array}{l}+ \\
\text { Tे } \\
\text { مे } \\
\infty \\
0\end{array}$ & $\underset$\[ \]${\vec{b}}$ & \text {$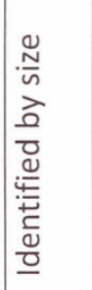 }$ \\
\hline \text {$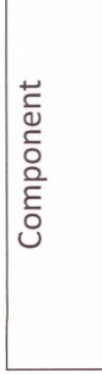 }$ & \text {$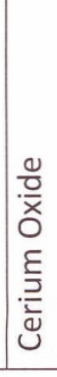 }$ & \text {$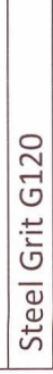 }$ & $\frac{\frac{m}{1}}{\frac{0}{\alpha}}$ & \text {$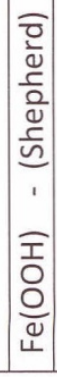 }$ & \text {$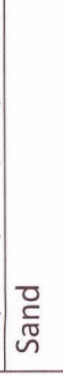 }$ & \text {$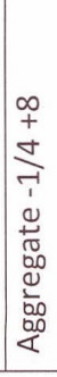 }$ & \text {$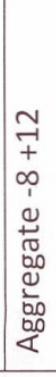 }$ & \text {$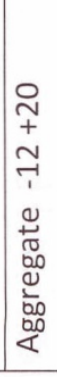 }$ & \text {$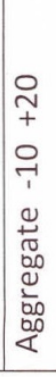 }$ & \text {$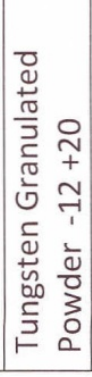 }$ & \text {$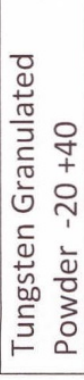 }$ & \text {$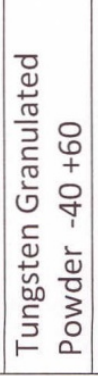 }$ & \text {$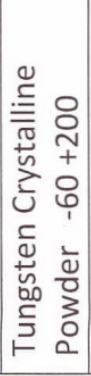 }$ & \text {$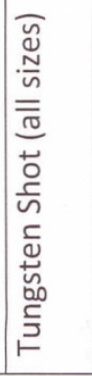 }$ \\
\hline
\end{tabular}




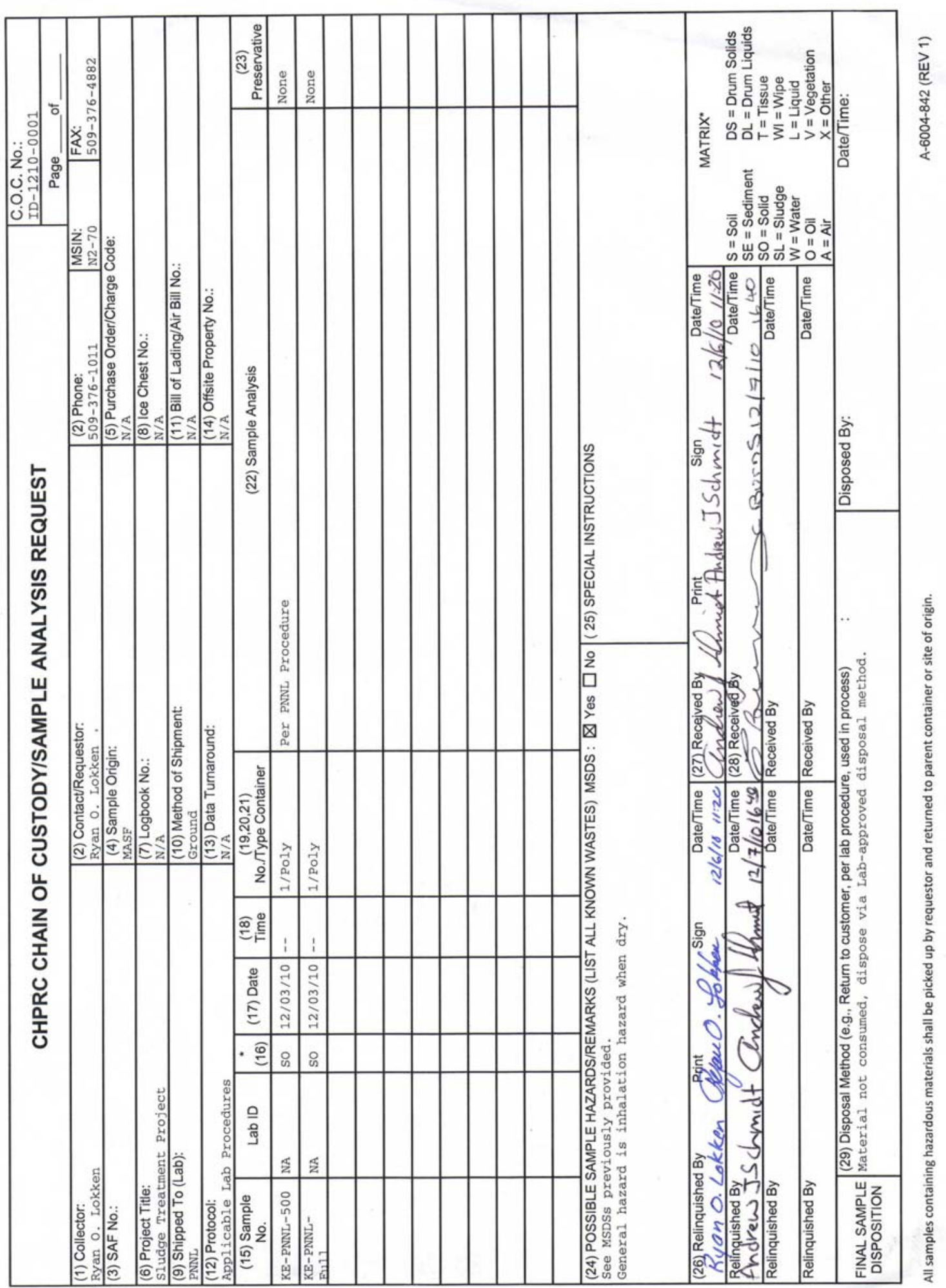




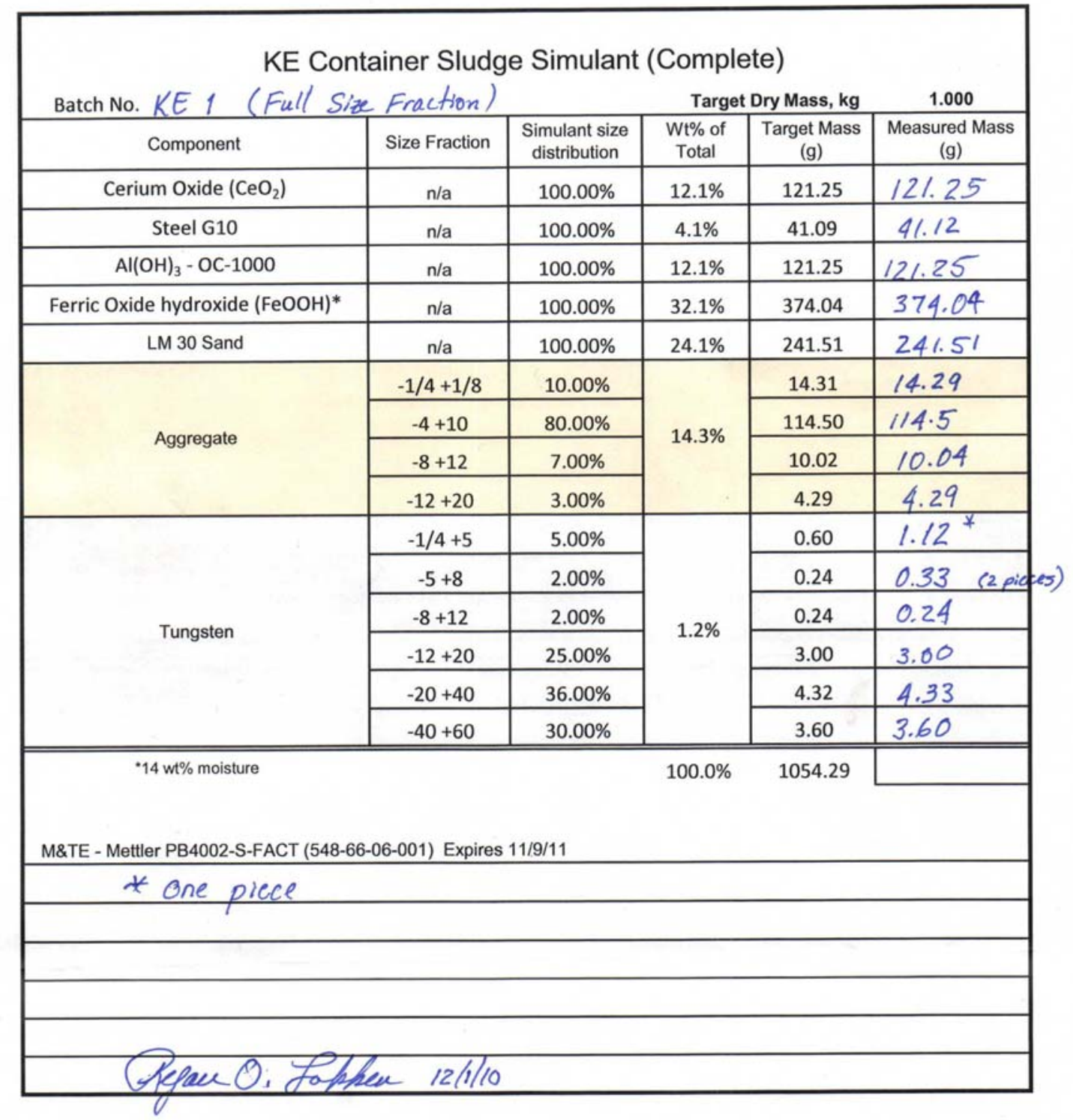

KE Recipe and Batch Sheet (PNNL).xlsx 


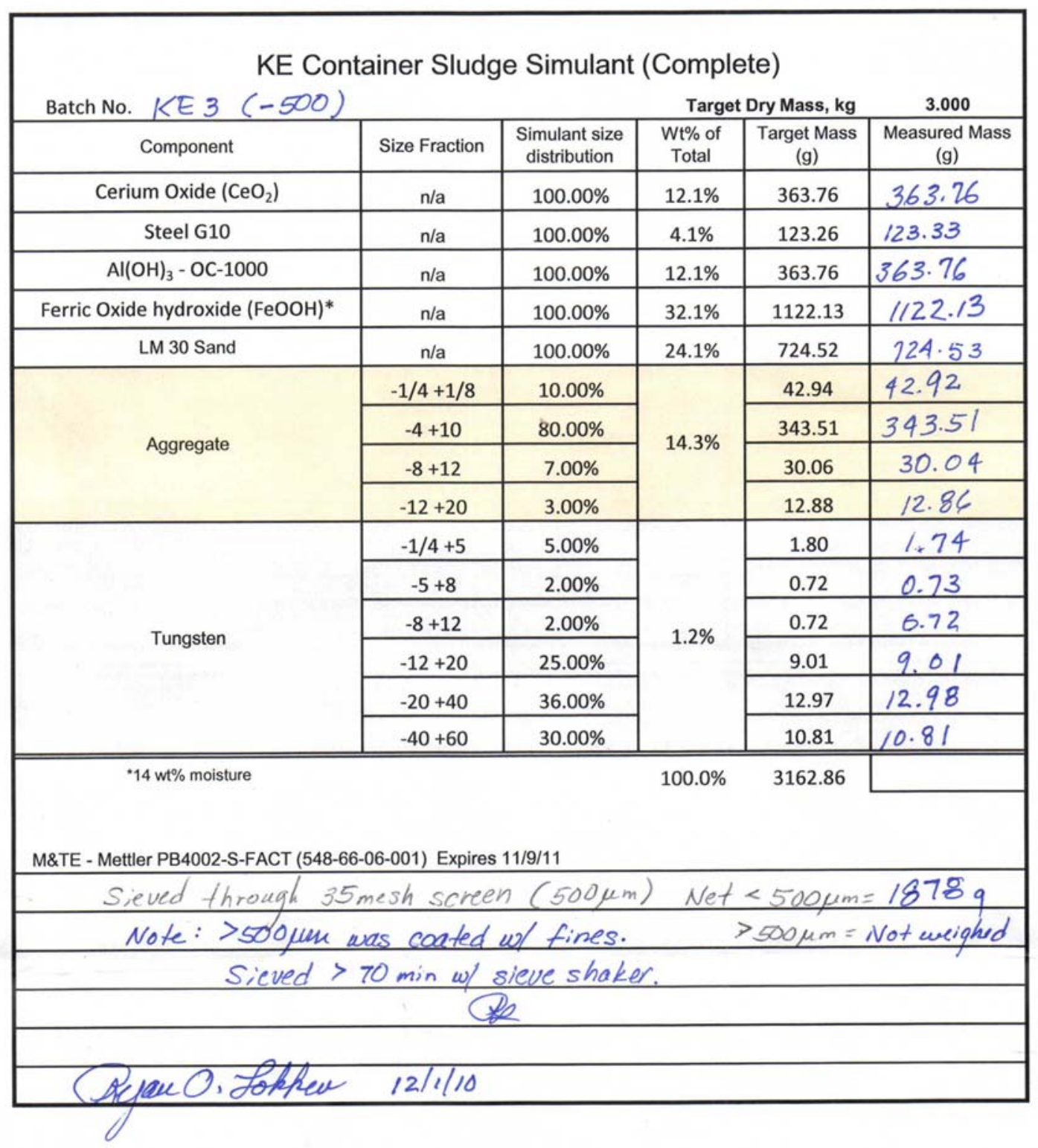

KE Recipe and Batch Sheet (PNNL).xIsx 
Two batches of the KE Container Sludge Simulant were prepared by STP staff at MASF (Maintenance and Storage Facility) in accordance with the formulation given in Table 7.1 of PRC-STP-00034. Each simulant component was weighed then combined. All weight measurements were performed to the nearest 0.01 gram, using a calibrated balance as indicated on the batch sheets. For one batch, the combined material was then subjected to dry sieving [through a \#35 (500 micron) sieve using mechanical agitation for approximately 70 minutes] to create a plus $500-\mu \mathrm{m}$ and a minus $500-\mu \mathrm{m}$ fraction. Only the minus $500-\mu \mathrm{m}$ fraction was retained for shipment to PNNL. The following summarizes the sample fractionation:

KE-Origin Container Sludge Simulant for Simulant Characterization

\begin{tabular}{|l|l|}
\hline Fraction ID & Mass, $\boldsymbol{g}$ \\
\hline Full Simulant Batch 1 & 1000 \\
\hline Full Simulant Batch 2 & 3000 \\
\hline$+500 \mu \mathrm{m}$ Fraction & Not measured \\
\hline$-500 \mu \mathrm{m}$ Fraction & 1878 \\
\hline
\end{tabular}

KE Simulant Components

\begin{tabular}{|c|c|c|c|}
\hline Component & Vendor/Supplier & $\begin{array}{c}\text { Size } \\
\text { Fraction }\end{array}$ & Lot No. \\
\hline Cerium Oxide $\left(\mathrm{CeO}_{2}\right)$ & $\begin{array}{l}\text { Molycorp Minerals, LLC } \\
\text { HC-1 Box } 224 \\
67750 \text { Bailey Road } \\
\text { Mountain Pass, CA } 92366\end{array}$ & $\mathrm{~N} / \mathrm{A}$ & 5310-3-1009-1 \\
\hline Steel G10 & Ervin Industries - AMASTEEL Division & $\mathrm{N} / \mathrm{A}$ & AV1000924 \\
\hline $\mathrm{Al}(\mathrm{OH})_{3}-\mathrm{OC}-1000$ & $\begin{array}{l}\text { Almatis, Inc. } \\
\text { PO Box } 300 \\
\text { 4701 Alcoa Rd } \\
\text { Bauxite, AR } 72002\end{array}$ & $\mathrm{~N} / \mathrm{A}$ & 723131304 \\
\hline FeOOH (Shepherd) & $\begin{array}{l}\text { The Shepherd Chemical Company, } \\
4900 \text { Beech Street, } \\
\text { Cincinnati, OH } 45212\end{array}$ & $\mathrm{~N} / \mathrm{A}$ & 1048410 \\
\hline LM 30 Sand & $\begin{array}{l}\text { Lane Mountain Company } \\
\text { PO Box } 127 \\
\text { Valley, WA } 99181\end{array}$ & $\mathrm{~N} / \mathrm{A}$ & N/A \\
\hline \multirow[t]{4}{*}{ Aggregate } & \multirow{4}{*}{$\begin{array}{l}\text { AGSCO Corporation } \\
160 \text { W. Hintz Road } \\
\text { Wheeling, IL } 60090\end{array}$} & $-1 / 4+1 / 8$ & 062209 \\
\hline & & $-4+8$ & 030408 \\
\hline & & $-8+12$ & 062209 \\
\hline & & $-12+20$ & 062209 \\
\hline \multirow[t]{6}{*}{ Tungsten } & \multirow{3}{*}{$\begin{array}{l}\text { Buffalo Tungsten, Inc. } \\
2 \text { Main St. } \\
\text { Depew, NY } 14043\end{array}$} & $-1 / 4+5$ & GW-1/405-1004-2 \\
\hline & & $-5+8$ & GW-0508-0910 \\
\hline & & $-8+12$ & GW-0812-0910 \\
\hline & \multirow{3}{*}{$\begin{array}{l}\text { ATI Engineered Products } \\
7300 \text { Highway } 20 \mathrm{~W} . \\
\text { Huntsville, AL } 35806\end{array}$} & $-12+20$ & GT657 \\
\hline & & $-20+40$ & GT-728 \\
\hline & & $-40+60$ & GT-729 \\
\hline
\end{tabular}


Appendix B

\section{Particle-Size Distribution Data}




\section{Appendix B: Particle-Size Distribution Data}

Particle-size distributions (PSDs), (Volume), obtained for the settler (ST-A), KW-B M500, KE-PNNL-500 and the KE-PNNL-Full ( $<500 \mu \mathrm{m}$ size fraction) simulants are given in this section. The average PSD obtained with $75 \%$ sonication has been used throughout this report and discussed in Section 3.2 for both the settler simulant and the KW-B M500 simulant. The KE simulant samples were analyzed using a different dispersion unit with $100 \%$ sonication. The effects of both sonication and refractive index (RI) have been illustrated and are included along with the number average PSD for both the settler and KW-B M500 simulants. The KW-B M500 simulant was analyzed as received, a dry powder, and as the settled wet simulant; both sets of data are given here on page B.8 for comparison purposes. A summary of the average volume (and number for the Settler and KW-B M500 Simulants) PSD for each simulant characterized is given below.

\begin{tabular}{|c|c|c|c|c|c|c|c|}
\hline Simulant ID & Plot Type & RI & $\begin{array}{c}\text { Sonication } \\
\text { Power }\end{array}$ & $\begin{array}{c}\text { No of } \\
\text { Measurements } \\
\text { Averaged } \\
\end{array}$ & $\begin{array}{c}\mathrm{d}(10) \\
\mu \mathrm{m}\end{array}$ & $\begin{array}{c}\mathrm{d}(50) \\
\mu \mathrm{m}\end{array}$ & $\begin{array}{c}\mathrm{D}(90) \\
\mu \mathrm{m}\end{array}$ \\
\hline Settler Simulant-75 & Volume & 2.94 & 75 & 14 & 2.6 & 13.6 & 334 \\
\hline Settler Simulant-75 & Number & 2.94 & 75 & 14 & 0.35 & 0.53 & 1.2 \\
\hline KW-B M500-75 & Volume & 2.94 & 75 & 5 & 2.83 & 24.6 & 344 \\
\hline KW-B M500-75 & Number & 2.94 & 75 & 5 & 0.30 & 0.44 & 0.95 \\
\hline $\begin{array}{l}\text { KE-PNNL-500- } \\
\text { Sonicated (sample } \\
\text { provided from STP } \\
\text { pre-sieved) }\end{array}$ & Volume & 2.42 & 100 & 15 & 0.66 & 8.02 & 70.8 \\
\hline $\begin{array}{l}\text { KE-PNNL-Full- } \\
\text { Sonicated }(<500 \mu \mathrm{m} \\
\text { sieved fraction, } \\
\text { sample sieved at } \\
\text { PNNL) }\end{array}$ & Volume & 2.42 & 100 & 15 & 1.04 & 10.9 & 383 \\
\hline
\end{tabular}




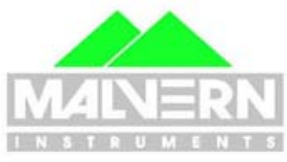

Sample Name: Settler Simulant_4 aliquots

Settler Simulant ST-A
average PSD from obtained
from 4 sub samples

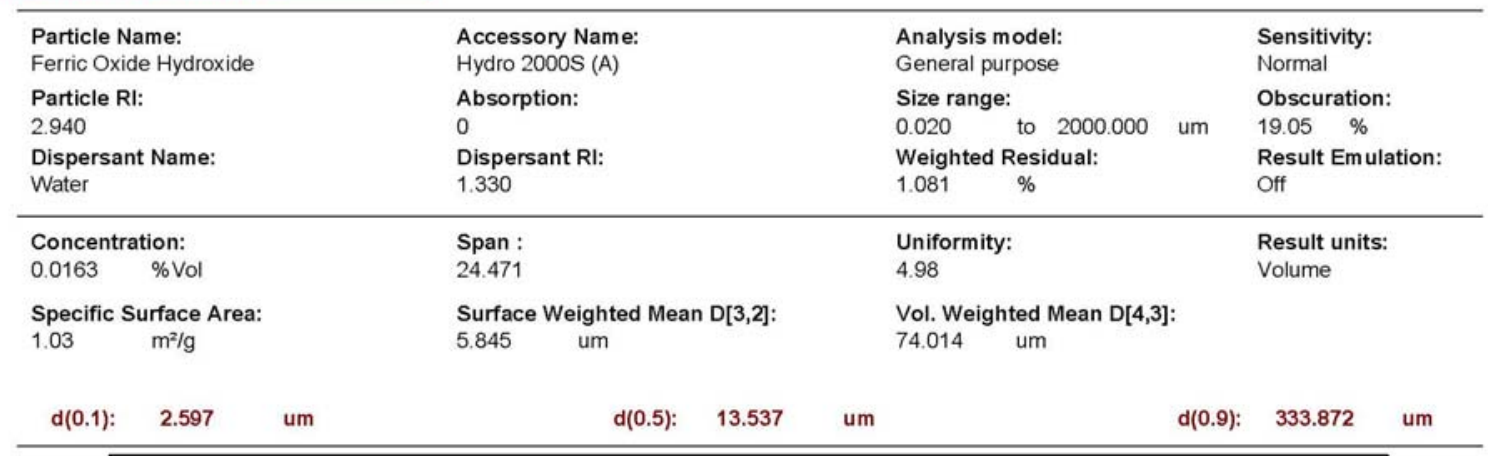

\section{Result Analysis Report}

SOP Name:

Measured by:

d3m514

Result Source:

Averaged
Measured:

Friday, March 27, 2009 2:14:38 PM

Analysed:

Friday, March 27, 2009 2:14:40 PM

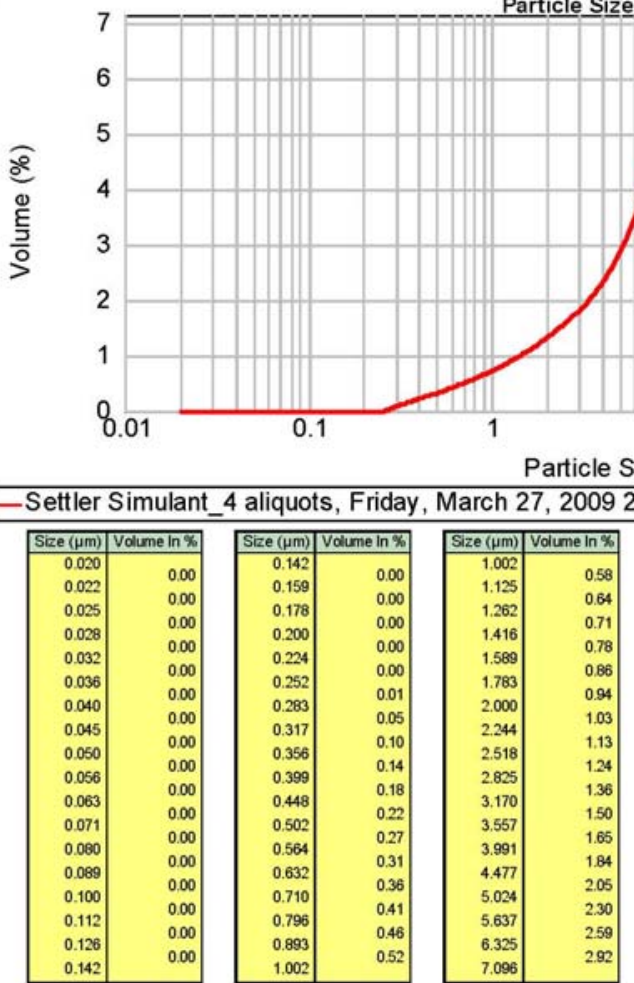

Operator notes:

Average of 14 measurements from 090327 mea
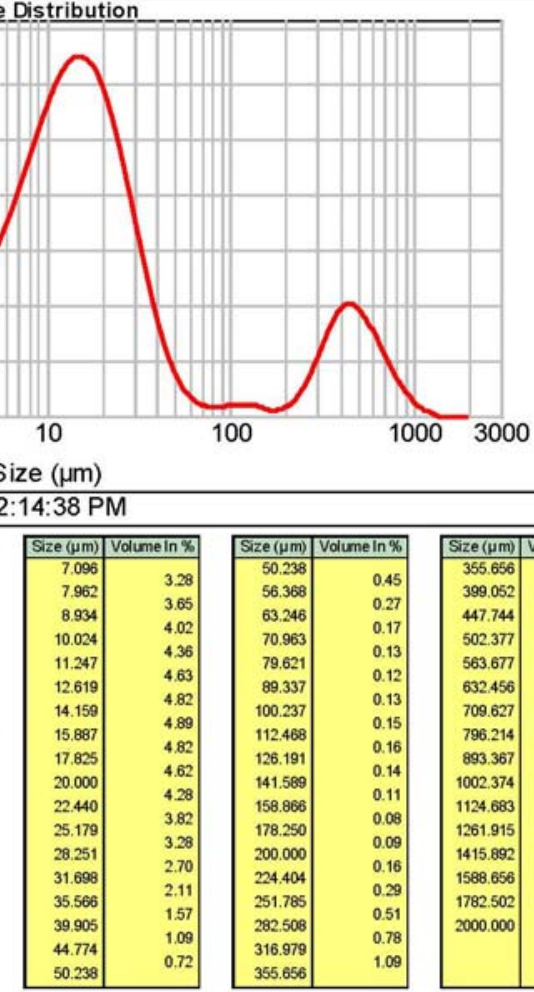

000

\begin{tabular}{|r|r|}
\hline Size ( $\mu \mathrm{m})$ & Volume In $\%$ \\
\hline 50.238 & 0.45 \\
56.368 & 0.27 \\
63.246 & 0.17 \\
70.963 & 0.13 \\
79.621 & 0.12 \\
89.337 & 0.13 \\
100.237 & 0.15 \\
112.468 & 0.16 \\
126.191 & 0.14 \\
141.569 & 0.11 \\
158.866 & 0.08 \\
178.250 & 0.09 \\
200.000 & 0.16 \\
224.404 & 0.29 \\
251.785 & 0.51 \\
282.508 & 0.78 \\
316.979 & 1.09 \\
355.656 & \\
\hline
\end{tabular}

\begin{tabular}{|r|r|}
\hline Size $(\mu \mathrm{mm})$ & Volume In $\%$ \\
\hline 355.656 & 1.35 \\
399.052 & 1.51 \\
447.744 & 1.52 \\
502.377 & 1.39 \\
563.677 & 1.16 \\
632.456 & 0.90 \\
709.627 & 0.64 \\
796.214 & 0.43 \\
893.367 & 0.27 \\
1002.374 & 0.13 \\
1124.683 & 0.07 \\
1261.915 & 0.00 \\
1415.892 & 0.00 \\
1588.656 & 0.00 \\
1782.502 & 0.00 \\
2000.000 & \\
& \\
\hline
\end{tabular}




\section{MASTERSIZER 2000}

Result Analysis Report

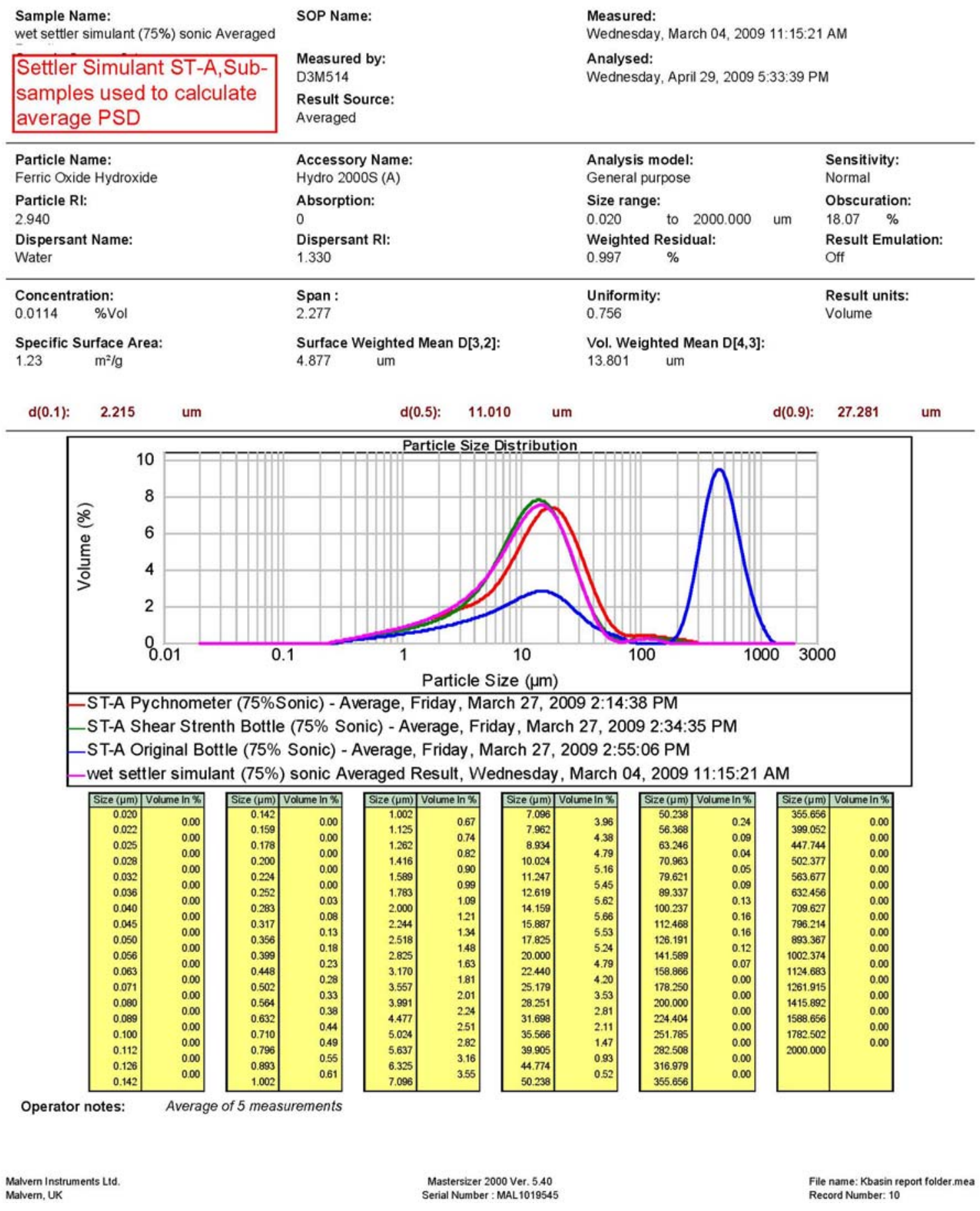




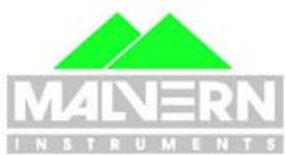

Sample Name: Wet Settler Simulant ( $75 \%$ Sonic) -

Sample Source \& type:

Settler Simulant ST-A, Effects of RI.

\section{MASTERSIZER 2000}

\section{Result Analysis Report}

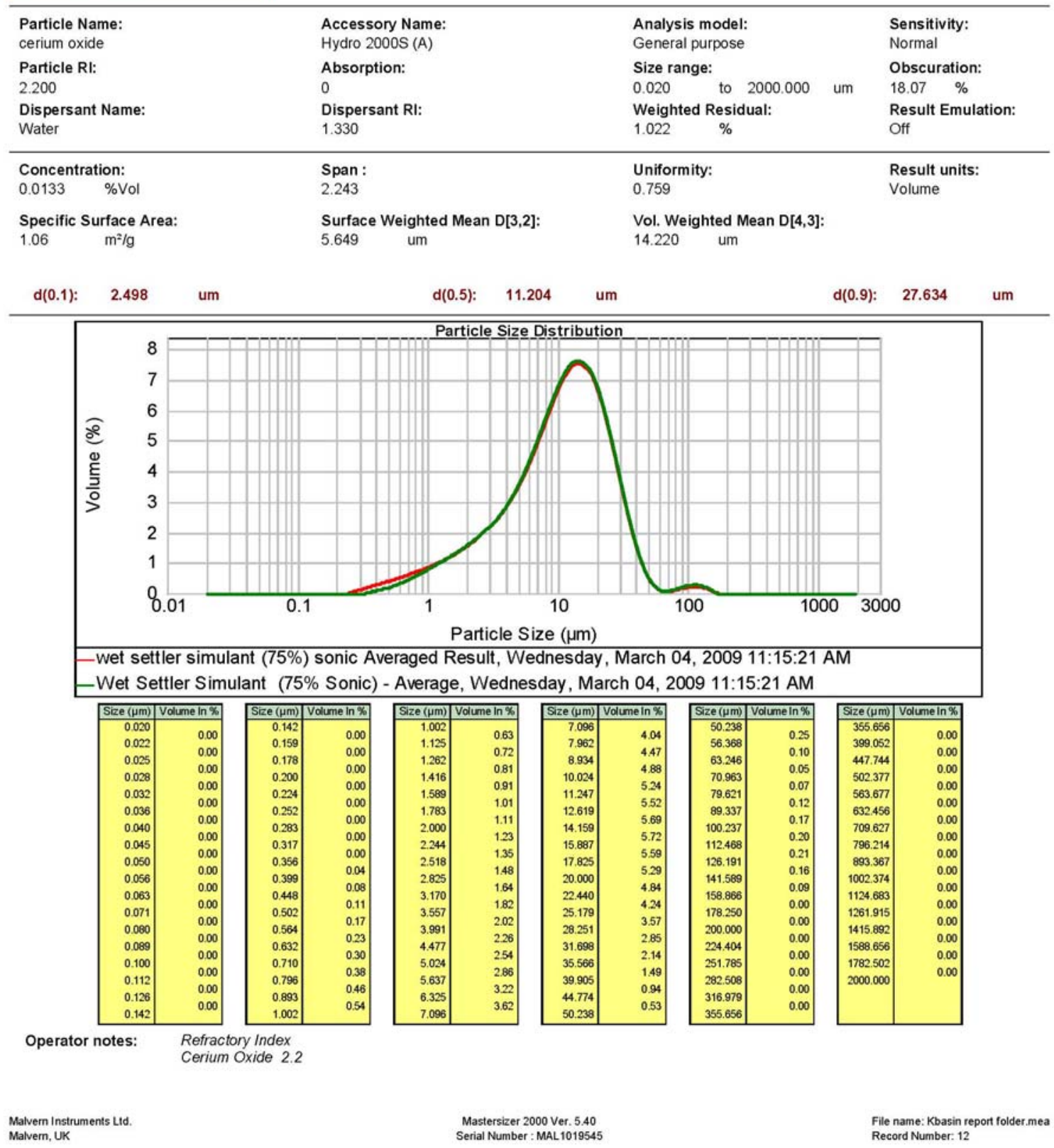




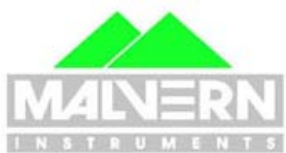

Sample Name: ST-A Original Bottle (Post Sonic) -

Sample Source \& type:

Settler Simulant ST-A,

Effects of Sonication

\section{MASTERSIZER 2000}

\section{Result Analysis Report}

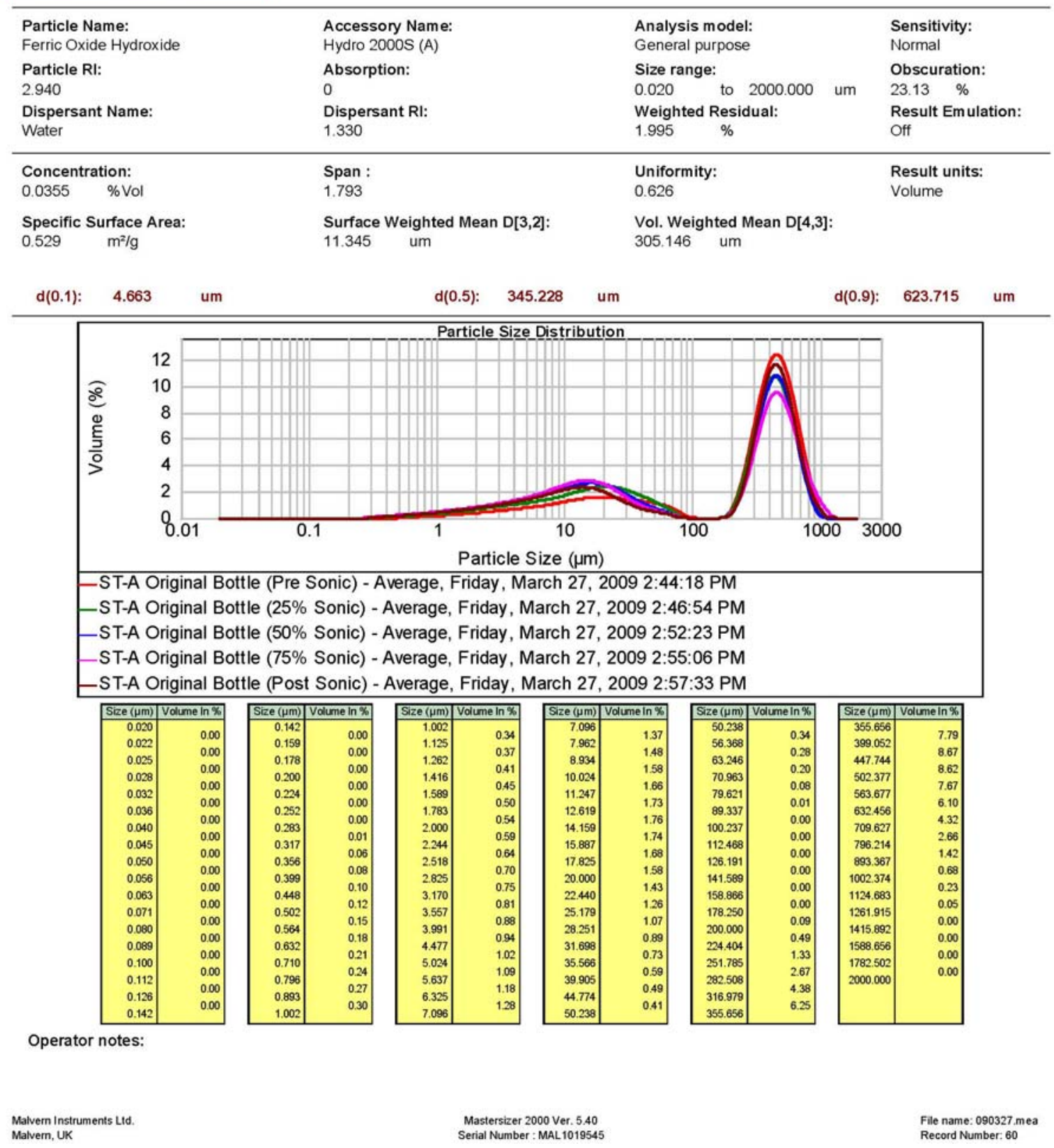




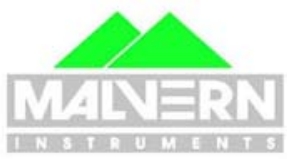

Sample Name: Settler Simulant (ST-A) _ $75 \%$ son_ Sample Source \& type: Settler Simulant, ST-A Number Averaged.

\section{MASTERSIZER 2000}

\section{Result Analysis Report}

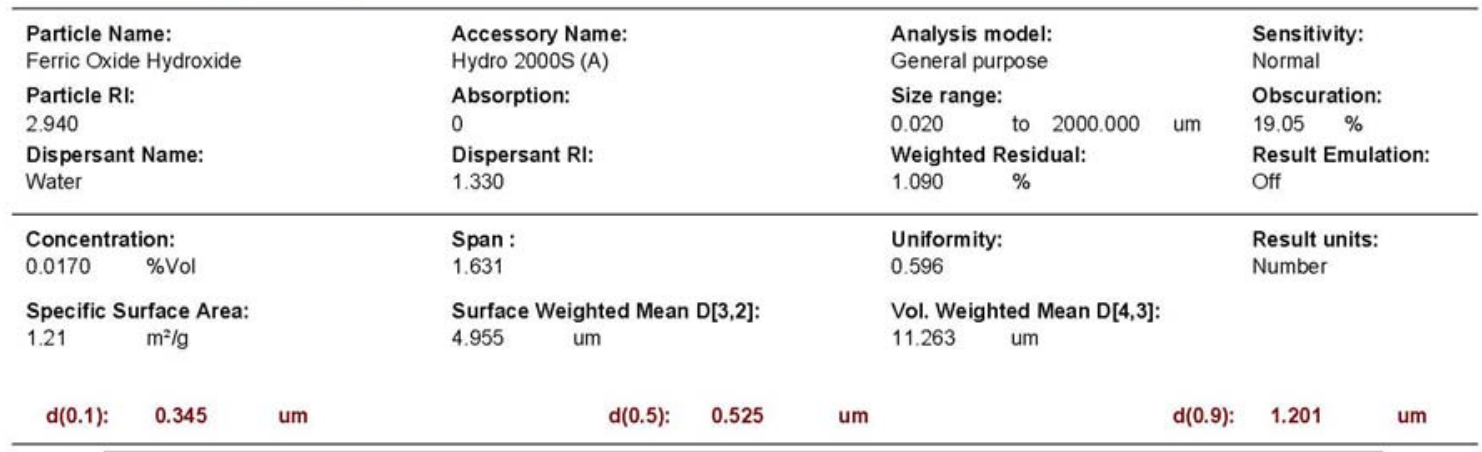

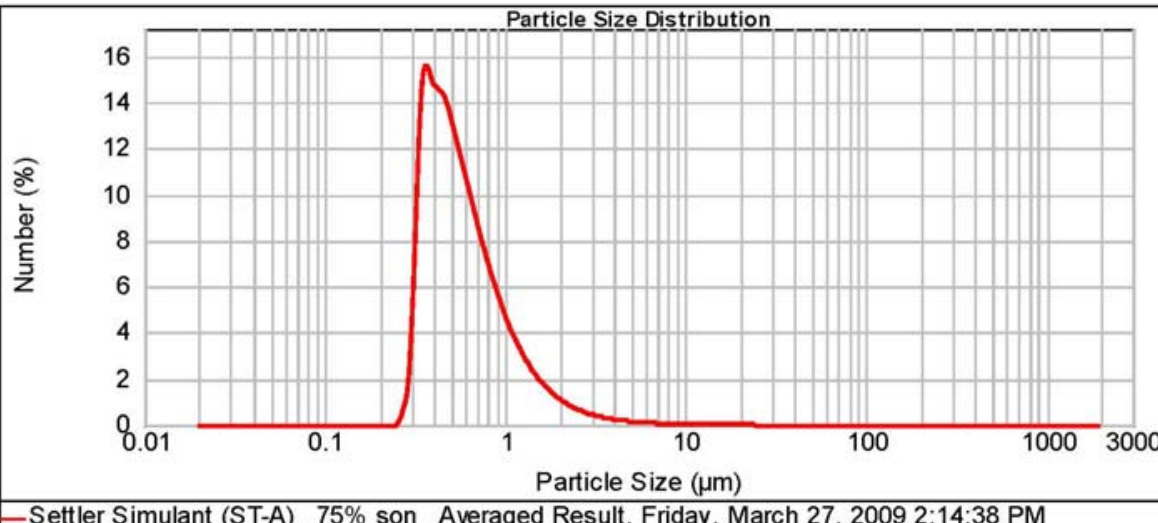

\begin{tabular}{|c|c|c|c|c|c|c|c|c|c|c|c|}
\hline Size (um) & Number $\ln \%$ & Size $(\mu \mathrm{m})$ & Number $\ln \%$ & Size ( $(\mathrm{\mu m})$ & Number In $\%$ & \begin{tabular}{|l|} 
Size $(\mu \mathrm{m})$ \\
\end{tabular} & Number $\ln \%$ & Size (um) & Number $\ln \%$ & Size $(\mu \mathrm{m})$ & Number $\ln \%$ \\
\hline 0.020 & 000 & 0.142 & & 1.002 & & 7.096 & 0.05 & 50.238 & 000 & 355.656 & 000 \\
\hline 0.022 & 0,0 & 0.159 & 00 & 1.125 & 251 & 7.962 & 0.04 & 56.368 & 0.00 & 399.052 & 0.00 \\
\hline 0.025 & 0.00 & 0.178 & 0.00 & 1.262 & $\begin{array}{l}2.91 \\
1.98\end{array}$ & 8.934 & 0.03 & 63.246 & 0.00 & 447.744 & 0.00 \\
\hline 0.028 & 0.00 & 0.200 & 0.00 & 1.416 & 1.55 & 10.024 & 0.02 & $\begin{array}{l}70.963 \\
77091\end{array}$ & 0.00 & 502.377 & 0.00 \\
\hline 0.032 & 0.00 & 0.224 & 0.00 & $\begin{array}{l}1.569 \\
1.783\end{array}$ & 1.21 & 11.247 & 0.02 & 79.621 & 0.00 & 563.677 & 0.00 \\
\hline 0.036 & 0.00 & . 0.282 & 0.34 & 2.1800 & 0.94 & $\begin{array}{l}12.619 \\
14159\end{array}$ & 0.01 & 10037 & 0.00 & 632.456 & 0.00 \\
\hline 0.040 & 0.00 & 0.283 & 238 & 2204 & 0.73 & $\begin{array}{l}14.159 \\
15897\end{array}$ & 0.01 & 100.237 & 0.00 & 709.627 & 0.00 \\
\hline 0.045 & 0.00 & $\begin{array}{l}0.317 \\
0.356\end{array}$ & 10.58 & $\begin{array}{l}2244 \\
2518\end{array}$ & 0.57 & 15887 & 0.01 & 112.468 & 0.00 & $\begin{array}{l}796.274 \\
893,37\end{array}$ & 0.00 \\
\hline 0.050 & 0.00 & 0.399 & 11.53 & $\begin{array}{l}2.518 \\
2825\end{array}$ & 0.44 & 20000 & 0.00 & 120.1591 & 0.00 & 893.367 & 0.00 \\
\hline 0.056 & 0.00 & 0.448 & 10.98 & 3.170 & 0.34 & 2040 & 0.01 & $\begin{array}{l}141.5899 \\
158.86\end{array}$ & 0.00 & $10023 / 4$ & 0.00 \\
\hline $\begin{array}{r}0.063 \\
0.071\end{array}$ & 0.00 & 0.502 & 10.48 & 3557 & 0.27 & $\begin{array}{l}22.440 \\
25.179\end{array}$ & 0.00 & 1588256 & 0.00 & $\begin{array}{l}1124.683 \\
1261915\end{array}$ & 0.00 \\
\hline $\begin{array}{l}0.071 \\
0.080\end{array}$ & 0.00 & 0.564 & 9.35 & 3.991 & 0.21 & 28251 & 0.00 & 200000 & 0.00 & 1415892 & 0.00 \\
\hline 0.089 & 0.00 & 0.632 & 8.17 & 4.477 & 0.16 & 31.698 & 0.00 & 224.404 & 0.00 & 1588.652 & 0.00 \\
\hline $\begin{array}{l}0.089 \\
0.100\end{array}$ & 0.00 & 0.710 & 6.98 & 5.024 & 0.13 & 35.566 & 0.00 & 251.785 & 0.00 & $\begin{array}{l}1588.050 \\
1782502\end{array}$ & 0.00 \\
\hline 0.112 & 0.00 & 0.796 & 5.84 & 5.637 & 0.10 & 39.905 & 0.00 & 282.508 & 0.00 & 2000.000 & 0.00 \\
\hline 0.126 & 0.00 & 0.893 & 4.81 & 6.325 & 0.08 & 44.774 & 0.00 & 316.979 & 0.00 & & \\
\hline 0.142 & 0.00 & 1.002 & 3.91 & 7.096 & 0.07 & 50.238 & 0.00 & 355.656 & 0.00 & & \\
\hline
\end{tabular}

Operator notes:

Average of 14 measurements from 4 different samples at $75 \%$ sonication

Measured:

riday, March 27, 2009 2:14:38 PM

Analysed:

d3m514

Monday, April 27, 2009 12:36:14 AM

Result Source:

Averaged

SOP Name: 


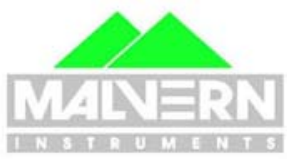

Settled KW-B M500 (75\% Sonic) - Average

Sample Source \& type:

KW_B M500 Data used in Report

Particle Name:

Ferric Oxide Hydroxide

Particle RI:

2.940

Dispersant Name:

Water

Concentration:

$0.0179 \%$ Vol

Specific Surface Area:

$0.887 \quad \mathrm{~m}^{2} / \mathrm{g}$

$d(0.1): \quad 2.823 \quad$ um

MASTERSIZER

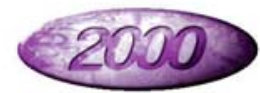

Result Analysis Report

SOP Name:

Measured by:

D3M514

Result Source:

Averaged

Measured:

Monday, March 02, 2009 3:37:08 PM

Analysed:

Monday, March 02, 2009 3:37:09 PM

Accessory Name:

Hydro 2000 S (A)

Absorption:

0

Dispersant RI:

1.330

Analysis model: $\quad$ Sensitivity:

General purpose

Size range:

0.020

to 2000.000 um

Obscuration:

$0.391 \%$

Result Emulation:

Uniformity:

Off

Span :

3.62

Result units:

Vol. Weighted Mean D[4,3]:

Surface Weighted Mean D[3,2]:

98.370

um

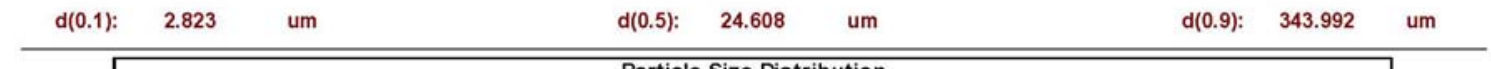

Particle Size Distribution 


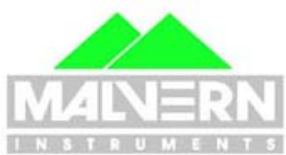

Settled KW-B M500 (75\% Sonic) - Average

Sample Source \& type:

KW_B M500 Dry sample and settled sample

\section{MASTERSIZER 2000}

\section{Result Analysis Report}

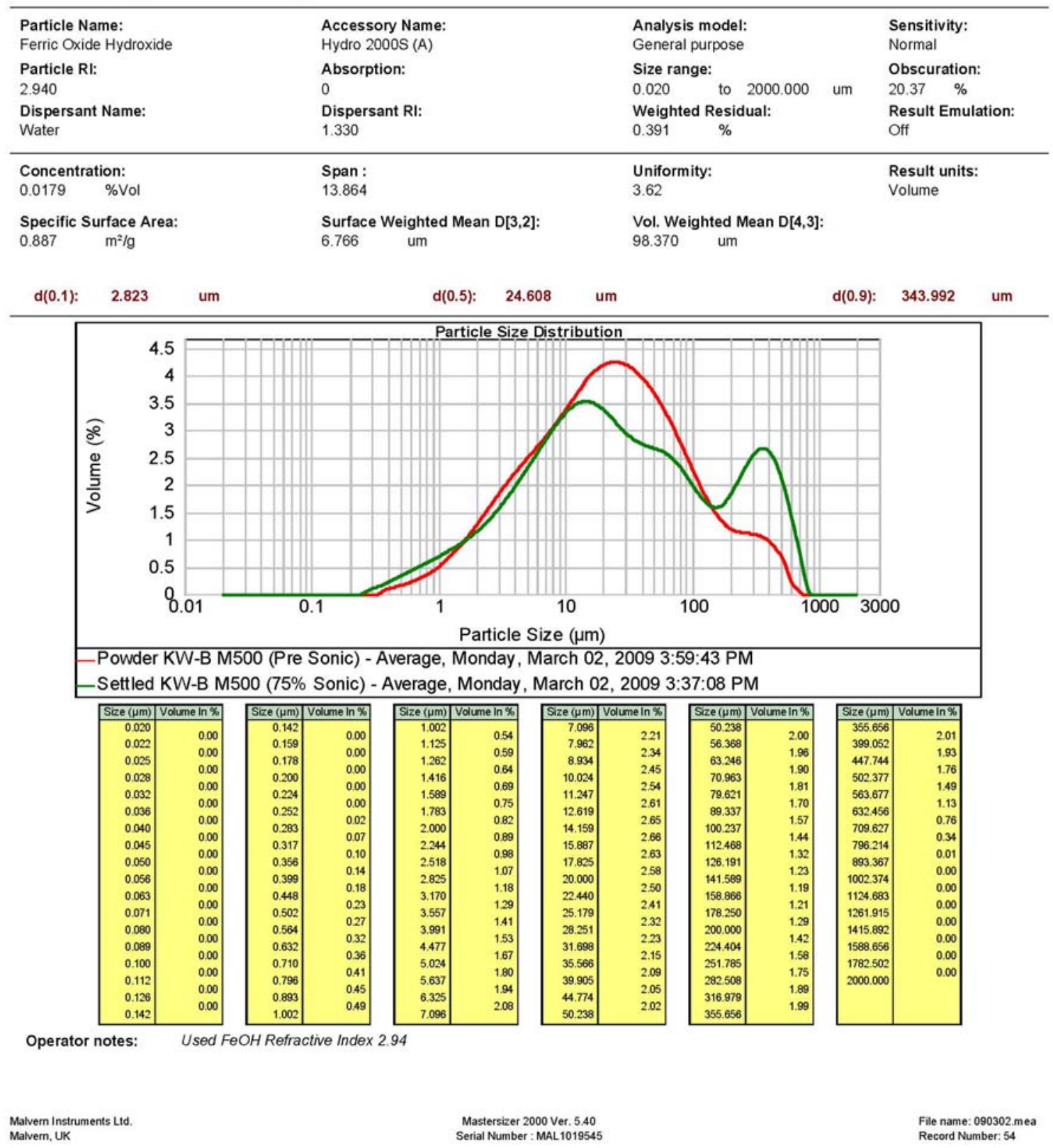

Monday, March 02, 2009 3:37:08 PM

Analysed:

Monday, March 02, 2009 3:37:09 PM

D3M514

Result Source:

Averaged 


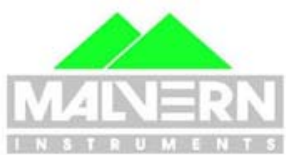

Sample Name: Settled KW-B M500 (75\% Sonic) - Average

Sample Source \& type:

KW_B M500 Effects of RI.

\section{MASTERSIZER 2000}

\section{Result Analysis Report}

SOP Name:

Measured by:

D3M514

Result Source:

Averaged

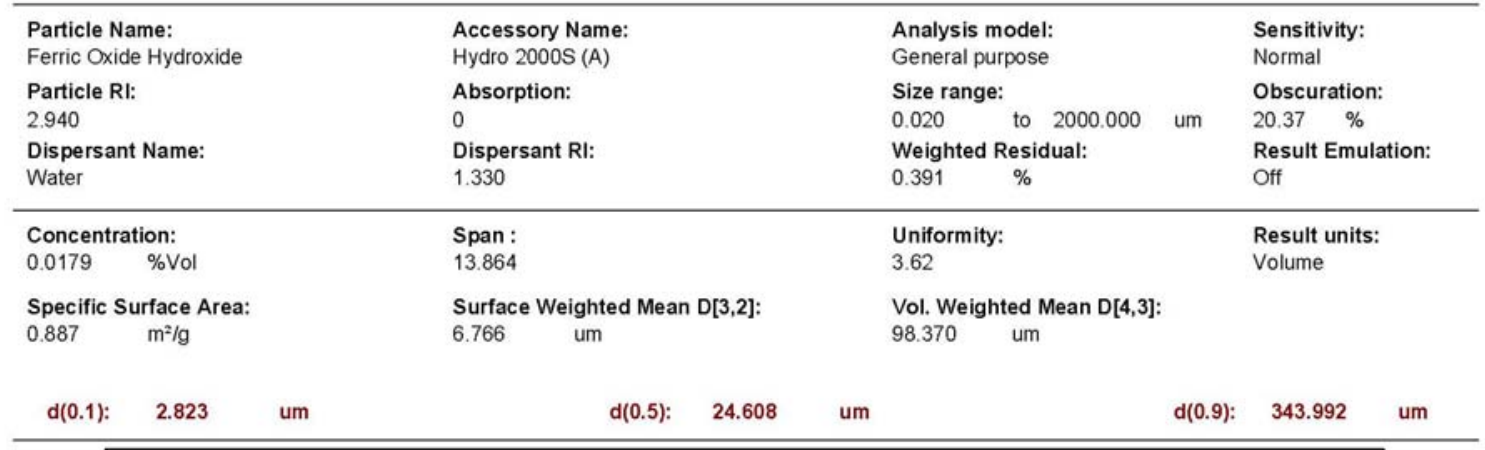

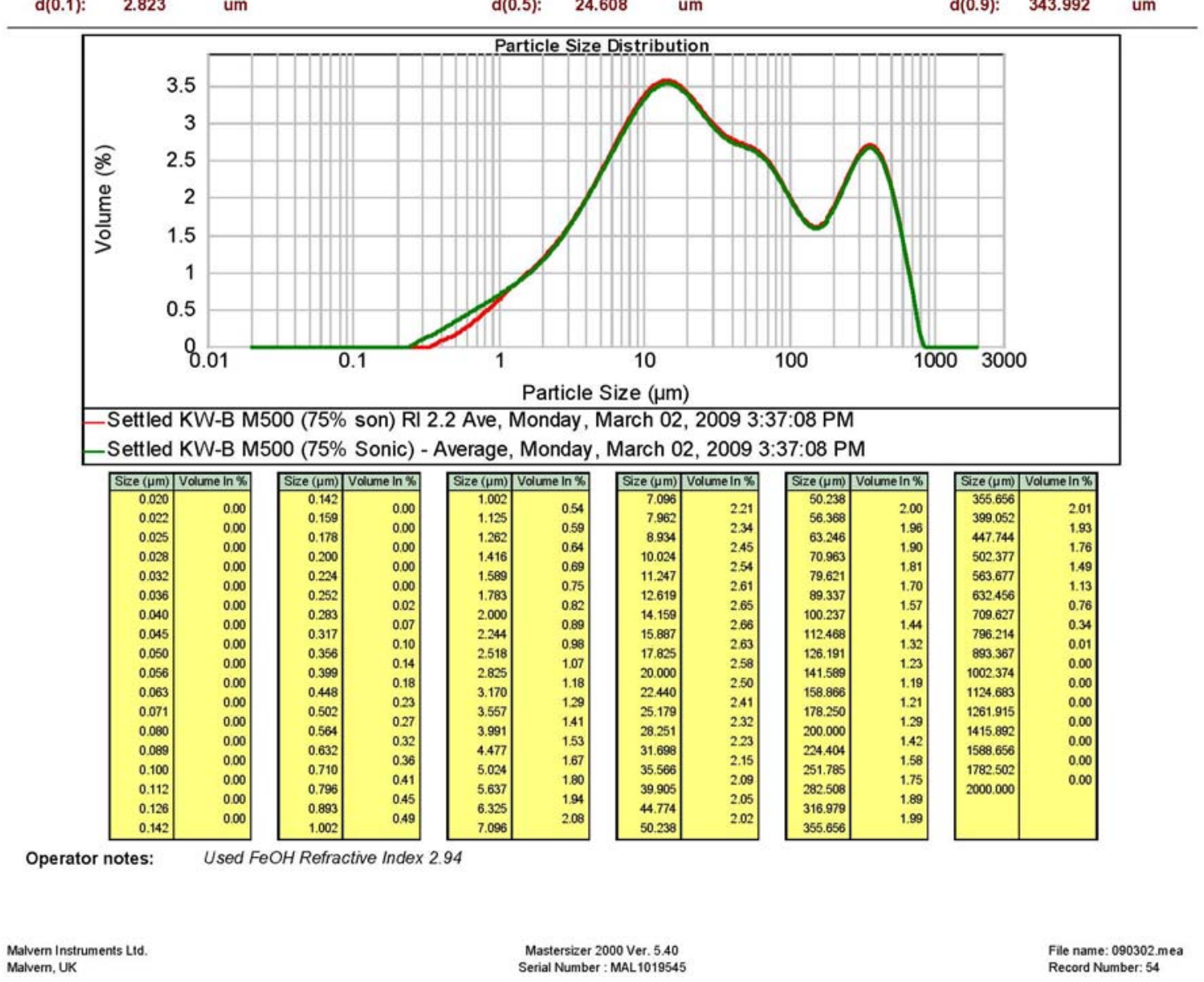

Monday, March 02, 2009 3:37:08 PM

Analysed:

Monday, March 02, 2009 3:37:09 PM

Obscuration:

Result Emulation:

Result units:

Vol. Weighted Mean D $[4,3]$

8.370 um 


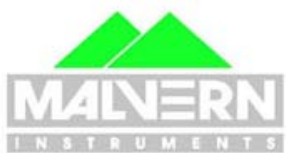

Settled KW-B M500 (Post Sonic) - Average

Sample Source \& type:

KW_B M500 Effects of sonication

\section{MASTERSIZER 2000}

\section{Result Analysis Report}

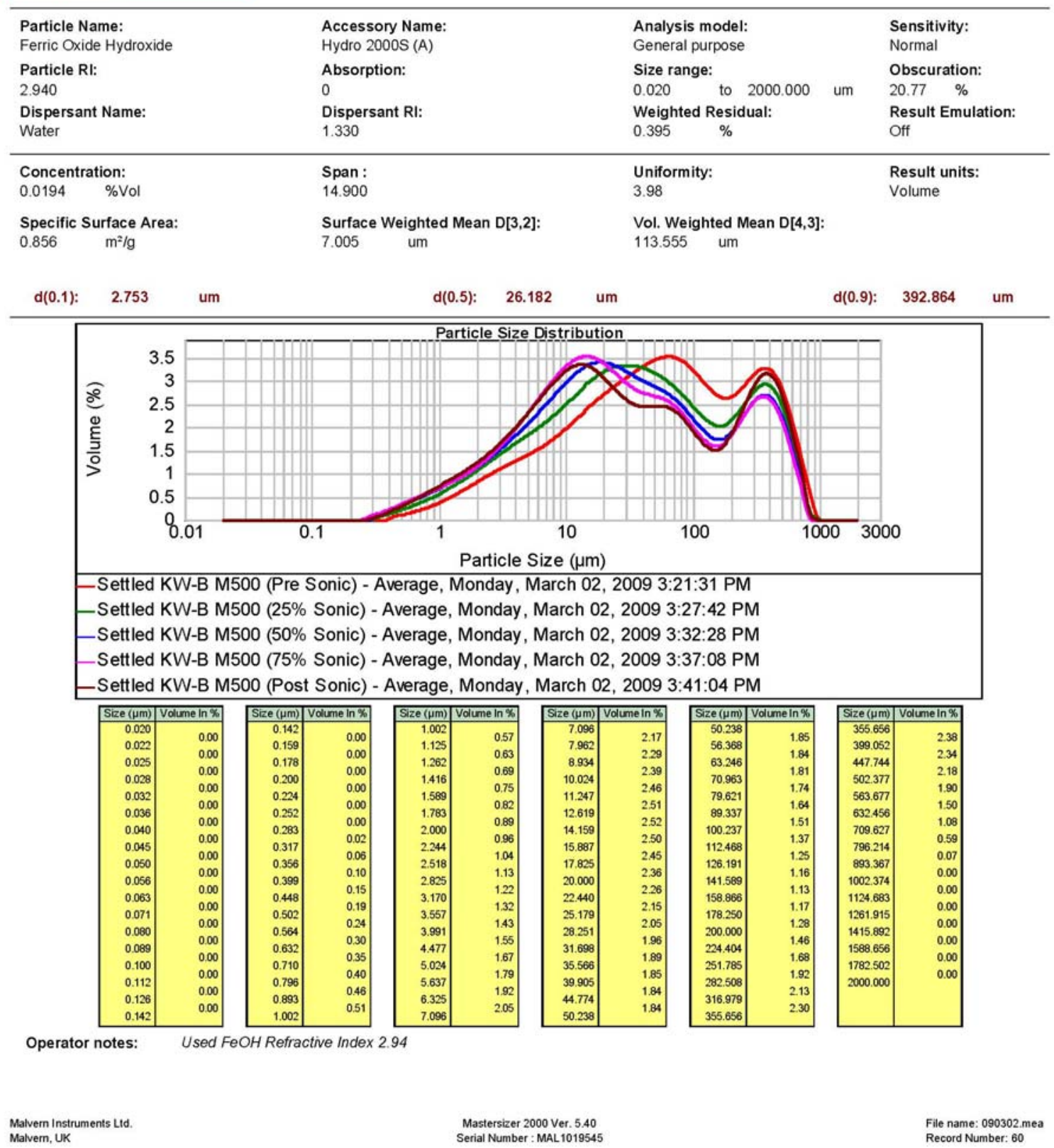

Monday, March 02, 2009 3:41:04 PM

Analysed:

Monday, March 02, 2009 3:41:05 PM

D3M514

Result Source:

Averaged 


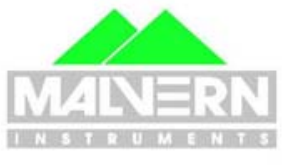

Sample Name:

KW-B M500 75\% son Number Averaged

Sample Source \& type:

KW_B M500 Number Averaged.

\section{MASTERSIZER 2000}

\section{Result Analysis Report}

SOP Name:

Measured by:

D3M514

Result Source: Averaged

\begin{tabular}{|c|c|c|c|}
\hline $\begin{array}{l}\text { Particle Name: } \\
\text { Ferric Oxide Hydroxide }\end{array}$ & $\begin{array}{l}\text { Accessory Name: } \\
\text { Hydro } 2000 \text { S (A) }\end{array}$ & $\begin{array}{l}\text { Analysis model: } \\
\text { General purpose }\end{array}$ & $\begin{array}{l}\text { Sensitivity: } \\
\text { Normal }\end{array}$ \\
\hline Particle RI: & Absorption: & Size range: & Obscuration: \\
\hline 2.940 & 0 & 0.020 to 2000.000 um & $20.37 \%$ \\
\hline Dispersant Name: & Dispersant RI: & \multirow{2}{*}{$\begin{array}{l}\text { Weighted Residual: } \\
0.391 \quad \%\end{array}$} & \multirow{2}{*}{$\begin{array}{l}\text { Result Emulation: } \\
\text { Off }\end{array}$} \\
\hline Water & 1.330 & & \\
\hline Concentration: & Span : & \multirow{2}{*}{$\begin{array}{l}\text { Uniformity: } \\
0.533\end{array}$} & \multirow{2}{*}{$\begin{array}{l}\text { Result units: } \\
\text { Number }\end{array}$} \\
\hline $0.0179 \quad \%$ Vol & 1.467 & & \\
\hline Specific Surface Area: & Surface Weighted Mean $\mathrm{D}[3,2]$ : & \multicolumn{2}{|l|}{ Vol. Weighted Mean D[4,3]: } \\
\hline $1.73 \quad \mathrm{~m}^{2} / \mathrm{g}$ & 3.467 um & 8.525 um & \\
\hline
\end{tabular}

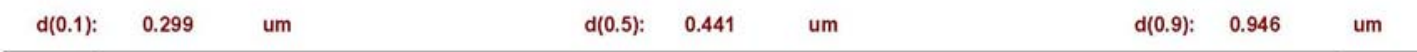

\begin{tabular}{|c|c|c|c|}
\hline & 18 & & \\
\hline & & & \\
\hline & 14 & & \\
\hline จ & & & \\
\hline or & 12 & & \\
\hline 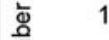 & 10 & & \\
\hline हે & 8 & & \\
\hline & 6 & & \\
\hline & 4 & & \\
\hline & 2 & & \\
\hline & & & \\
\hline & 0.01 & 0 . & \\
\hline$-\mathrm{KW}-\mathrm{B}$ & M500 75\% & son Num & nber Ave \\
\hline $\begin{array}{l}\text { Size }(\mu \mathrm{m}) \\
\end{array}$ & Number $\ln \%$ & 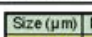 & Number In $\%$ \\
\hline 0.020 & & \begin{tabular}{|l|}
0.142 \\
\end{tabular} & \\
\hline 0.022 & 0.00 & 0.159 & 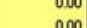 \\
\hline 0.025 & 0.00 & 0.178 & $\begin{array}{l}0.00 \\
0.00\end{array}$ \\
\hline 0.028 & 0.00 & 0.200 & 0.00 \\
\hline 0.032 & 0.00 & $\begin{array}{l}0.224 \\
0.252\end{array}$ & 0.00 \\
\hline 0.040 & 0.00 & 0.283 & 387 \\
\hline 0.045 & 0.00 & 0.317 & 13.14 \\
\hline 0.050 & 0.00 & 0.356 & 11.73 \\
\hline 0.056 & $\begin{array}{l}0.00 \\
0.00\end{array}$ & 0.399 & $\begin{array}{l}11.68 \\
10.93\end{array}$ \\
\hline 0.063 & 0.00 & 0.448 & 9.47 \\
\hline 0.071 & 0.00 & 0.502 & 8.09 \\
\hline $\begin{array}{l}0.060 \\
0.069\end{array}$ & 0.00 & $\begin{array}{l}0.564 \\
0.632\end{array}$ & 6.67 \\
\hline 0.100 & 0.00 & 0.710 & 5.40 \\
\hline 0.112 & 0.00 & 0.796 & 4.29 \\
\hline 0.126 & 0.00 & 0.893 & 3.36 \\
\hline 0.142 & & 1.002 & \\
\hline
\end{tabular}

Operator notes:

Average of 5 measurements

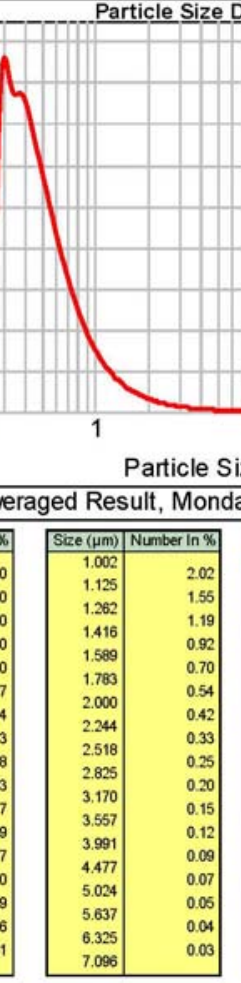

Monday, March 02, 2009 3:37:08 PM

Analysed:

Monday, April 27, 2009 2:33:27 AM 


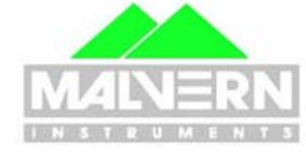

Sample Name: KE-PNNL-500-PSD-Unsonicated-Average KE-PNNL-500unsonicated average obtained from 5 sub samples

Particle Name:

Iron III Oxide_1

Particle RI:

2.420

Dispersant Name

Water

Concentration:

$0.0028 \quad \%$ Vol

Specific Surface Area:

$2.07 \quad \mathrm{~m}^{2} / \mathrm{g}$

$d(0.1): \quad 0.841$

\section{MASTERSIZER 2000}

\section{Result Analysis Report}

SOP Name:

Measured by:

D3M966

Result Source:

Averaged
Measured:

Friday, February 11, 2011 12:24:45 PM

Analysed:

Friday, February 11, 2011 12:24:47 PM

0.841 um $\quad d(0.5): \quad 17.762$ um $\quad d(0.9): \quad 298.611 \quad$ um

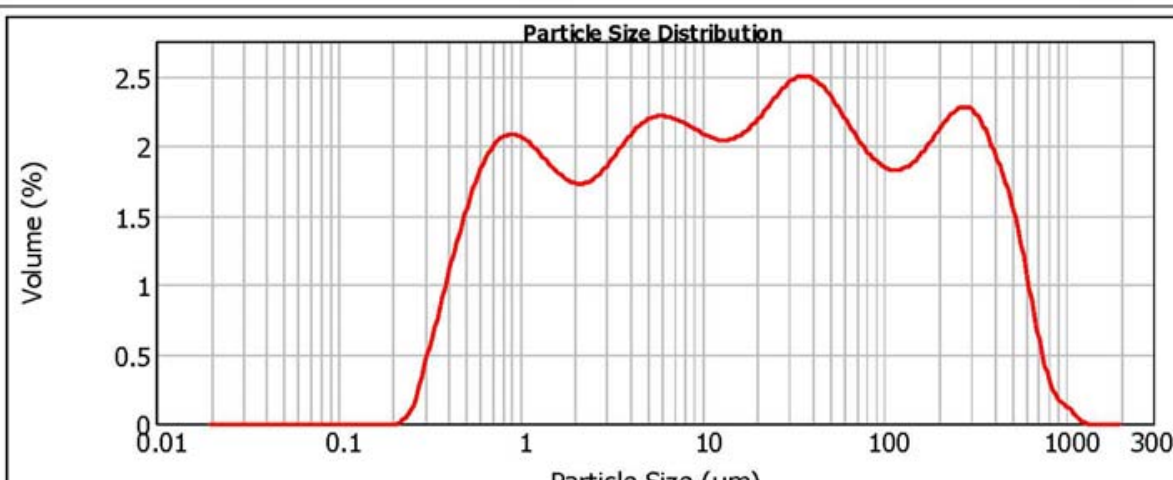

Particle Size $(\mu \mathrm{m})$

—KE-PNNL-500-PSD-Unsonicated-Average, Friday, February 11, 2011 12:24:45 PM

\begin{tabular}{|c|c|c|c|c|c|c|c|c|c|c|c|}
\hline Size $(\mu \mathrm{m})$ & Volume in $\%$ & Size $(\mu \mathrm{m})$ & Volume in $x$ & Size $(\mu \mathrm{m})$ & Volume in $\%$ & Size $(\mu \mathrm{m})$ & Volume In $\%$ & Size $(\mu \mathrm{m})$ & Volume In $\%$ & Size $(\mu \mathrm{m})$ & Volume $\ln \%$ \\
\hline 0.020 & & 0.142 & 0.00 & 1.002 & 154 & 7.096 & 16 & 50.238 & 1. & 355.656 & 1.55 \\
\hline 0.022 & 0.00 & 0.159 & 0.00 & 1.125 & 1.50 & 7.962 & 1.61 & 56.368 & 1.67 & 398.052 & 1.52 \\
\hline 0.025 & 0.00 & 0.178 & 0.00 & 1.262 & 1.44 & 8.934 & 1.58 & 63.246 & 159 & 447.744 & 1.28 \\
\hline 0.028 & 0.00 & 0.200 & 0.00 & 1.416 & 1.39 & 10.024 & 1.56 & 70.963 & 151 & 502.377 & 1.09 \\
\hline 0.032 & 0.00 & 0.224 & 0.04 & 1.589 & 1.34 & 11.247 & & 79.621 & 145 & 563.677 & 0.85 \\
\hline 0.036 & 0.00 & 0.252 & 0.04 & 1.783 & 1.31 & 12.619 & 1.54 & 89.337 & 1.40 & 632.456 & $\begin{array}{l}0.85 \\
0.58\end{array}$ \\
\hline 0.040 & 0.00 & 0.283 & 0.33 & 2.000 & 1.30 & 14.159 & 1.55 & 100.237 & 138 & 709.627 & $\begin{array}{l}0.58 \\
0.34\end{array}$ \\
\hline 0.045 & 0.00 & 0.317 & 0.50 & 2.244 & 1.31 & 15.887 & 1.57 & 112.468 & 1.37 & 796.214 & 0.18 \\
\hline 0.050 & 0.00 & 0.356 & 0.69 & 2.518 & 1.34 & 17.825 & 1.62 & 126.191 & 1.39 & 893.367| & 0.11 \\
\hline 0.056 & 0.00 & $\begin{array}{l}0.399 \\
0.448\end{array}$ & 0.89 & $\begin{array}{l}2.825 \\
3.170\end{array}$ & 1.40 & $\begin{array}{l}20.000 \\
22.440\end{array}$ & 1.67 & $\begin{array}{l}141.589 \\
158.866\end{array}$ & 1.43 & 1002.374 & 0.07 \\
\hline 0.063 & 0.00 & 0.448 & 1.07 & 3.557 & 1.46 & $\begin{array}{l}22.440 \\
25.179\end{array}$ & 1.74 & $\begin{array}{l}158.866 \\
178.250\end{array}$ & 1.49 & 1124.683 & 0.02 \\
\hline 0.071 & 0.00 & $\begin{array}{l}0.502 \\
0.564\end{array}$ & 1.23 & 3.991 & 1.53 & $\begin{array}{l}25.179 \\
28.251\end{array}$ & 1.80 & $\begin{array}{r}178.250 \\
200.000\end{array}$ & 1.56 & $\left|\begin{array}{l}1261.915 \\
145892\end{array}\right|$ & 0.00 \\
\hline 0.080 & 0.00 & $\begin{array}{l}0.564 \\
0.632\end{array}$ & 1.37 & $\begin{array}{l}3.991 \\
4.477\end{array}$ & 1.59 & $\begin{array}{l}28.251 \\
31.698\end{array}$ & 1.85 & $\begin{array}{l}200.000 \\
224.404\end{array}$ & 1.63 & $\begin{array}{l}1415.892 \\
1589.656\end{array}$ & 0.00 \\
\hline 0.089 & 0.00 & 0.031 & 1.47 & $\begin{array}{l}4.4717 \\
5.024\end{array}$ & 1.63 & - & 1.88 & $\begin{array}{l}224.484 \\
251.785\end{array}$ & 1.69 & 1588.650 & 0.00 \\
\hline 0.100 & 0.00 & $\begin{array}{l}0.710 \\
0.796\end{array}$ & 1.53 & $\begin{array}{l}5.037 \\
5.637\end{array}$ & 1.66 & 39.905 & 1.88 & 282.508 & 1.72 & $\left|\begin{array}{l}1782.502 \\
2000000\end{array}\right|$ & 0.00 \\
\hline $\begin{array}{l}0.112 \\
0.126\end{array}$ & 0.00 & 0.893 & 1.56 & 6.325 & 1.67 & $\begin{array}{l}39.905 \\
44.774\end{array}$ & 1.86 & $\begin{array}{l}282.508 \\
316.979\end{array}$ & 1.71 & & \\
\hline 0.142 & 0.00 & 1.002 & 1.56 & 7.096 & 1.66 & 50.238 & 1.81 & 355.656 & 1.65 & & \\
\hline
\end{tabular}

Operator notes: $\quad$ Average of 15 measurements from 53451-TIO37.mea

Malvern Instruments Ltd

Malvern, UK

Tel : $=+[441(0) 168+-892456 \mathrm{Fax}+[441(0) 168+892789$
Mastersizer 2000 Ver. 5.60 Serial Number : MAL1019545 um

\begin{tabular}{|c|c|c|}
\hline $\begin{array}{l}\text { Accessory Name: } \\
\text { Hydro } 2000 \mathrm{G} \text { (A) }\end{array}$ & $\begin{array}{l}\text { Analysis model: } \\
\text { General purpose }\end{array}$ & $\begin{array}{l}\text { Sensitivity: } \\
\text { Normal }\end{array}$ \\
\hline Absorption: & Size range: & Obscuration: \\
\hline 1 & 0.020 to 2000.000 um & 8.38 \\
\hline Dispersant RI: & Weighted Residual: & \multirow{2}{*}{$\begin{array}{l}\text { Result Emulation: } \\
\text { Off }\end{array}$} \\
\hline 1.330 & $0.948 \quad \%$ & \\
\hline Span : & Uniformity: & Result units: \\
\hline 16.764 & 4.69 & Volume \\
\hline Surface Weighted Mean D[3,2]: & Vol. Weighted Mean D[4,3]: & \\
\hline $2.896 \quad$ um & 88.025 um & \\
\hline
\end{tabular}




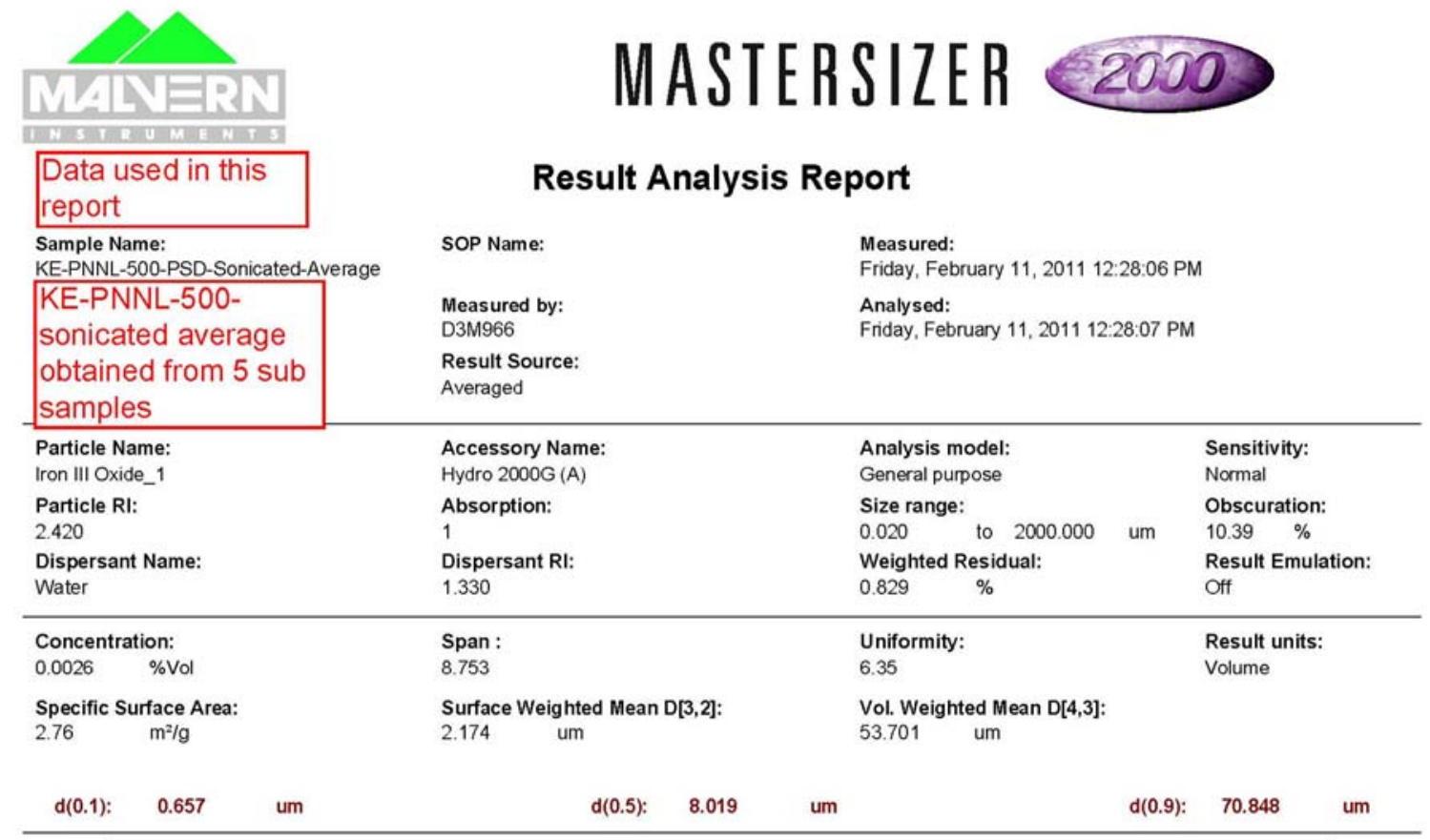

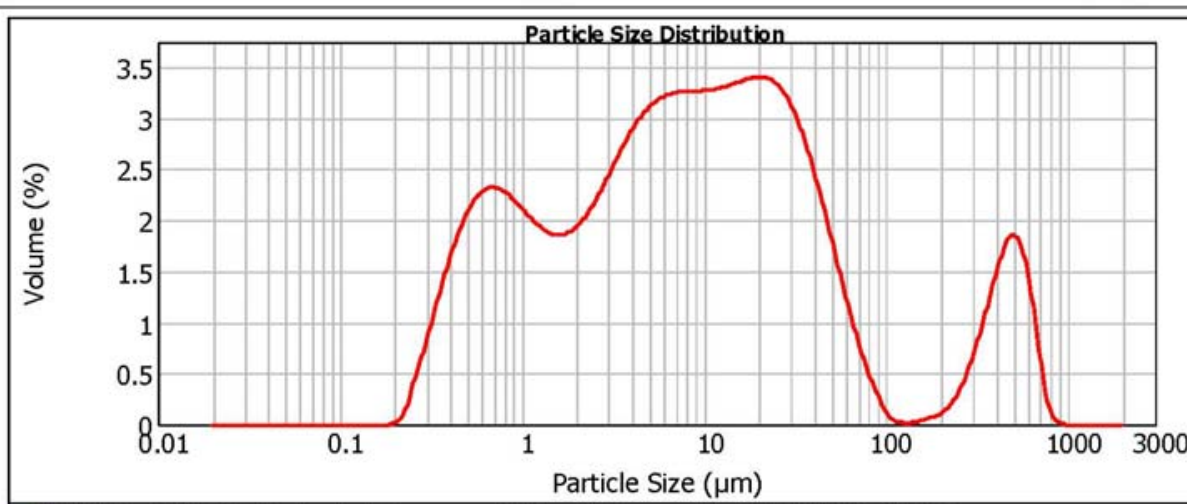

Particle Size $(\mu \mathrm{m})$

\begin{tabular}{|c|c|c|c|c|c|c|c|c|c|c|c|}
\hline \multicolumn{12}{|c|}{ 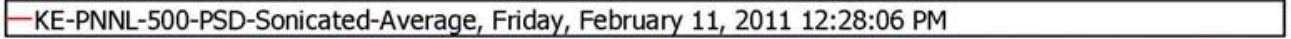 } \\
\hline Size ( $(\mu \mathrm{m})$ & Volume in $x$ & Size ( $\mu \mathrm{m})$ & Volume in $x$ & $\longdiv { \text { Size } ( \mu \mathrm { m } ) }$ & Volume in $\%$ & Size $(\mu \mathrm{m})$ & Volume $\ln \%$ & Size ( $\mu \mathrm{m})$ & Volume in $\%$ & Size ( $\mu \mathrm{m})$ & Volume $\ln \%$ \\
\hline 0.020 & 000 & 0.142 & & 1.002 & & 7.096 & & 50.238 & & \begin{tabular}{|c|}
355.656 \\
\end{tabular} & \\
\hline 0.022 & $\begin{array}{l}0.00 \\
0.00\end{array}$ & 0.159 & $\begin{array}{ll}0.00 \\
0.00\end{array}$ & 1.125 & $\begin{array}{l}1.55 \\
1.48\end{array}$ & 7.962 & $\begin{array}{l}2.45 \\
2.46\end{array}$ & 56.368 & $\begin{array}{l}1.21 \\
0.95\end{array}$ & 399.052 & $\begin{array}{l}0.98 \\
1.23\end{array}$ \\
\hline 0.025 & 0.00 & 0.178 & 0.00 & 1.262 & $\begin{array}{l}1.48 \\
1.42\end{array}$ & 8.934 & $\begin{array}{l}2.46 \\
2.46\end{array}$ & 63.246 & $\begin{array}{l}0.95 \\
0.70\end{array}$ & 447.744 & $\begin{array}{l}1.23 \\
1.39\end{array}$ \\
\hline 0.028 & 0.00 & 0.200 & 0.04 & 1.416 & 1.40 & 10.024 & $\begin{array}{l}2.40 \\
2.47\end{array}$ & 70.963 & 0.48 & 502.377 & 1.37 \\
\hline 0.032 & 0.00 & 0.224 & 0.18 & 1.589 & 1.40 & 11.247 & 2.48 & 79.621 & 0.30 & 563.677 & 1.13 \\
\hline 0.036 & 0.00 & 0.252 & 0.41 & 1.783 & 1.43 & 12.619 & 2.49 & 89.337 & 0.14 & 632.456 & 0.69 \\
\hline 0.040 & 0.00 & 0.283 & 0.63 & 2.000 & 1.50 & 14.159 & 2.52 & 100.237 & 0.04 & 709.627 & 0.22 \\
\hline 0.045 & 0.00 & 0.317 & 0.88 & 2.244 & 1.59 & 15.887 & 2.54 & 112.468 & 0.01 & 796.214 & 0.04 \\
\hline 0.050 & 0.00 & 0.356 & 1.11 & 2.518 & 1.71 & 17.825 & 2.56 & 126.191 & 0.01 & 893.367 & 0.00 \\
\hline 0.056 & 0.00 & 0.399 & 1.33 & 2.825 & 1.84 & 20.000 & 2.56 & 141.589 & 0.02 & 1002.374 & 0.00 \\
\hline 0.063 & 0.00 & 0.448 & 1.50 & 3.170 & 1.98 & 22.440 & 2.53 & 158.866 & 0.04 & 1124.683 & 0.00 \\
\hline 0.071 & 0.00 & 0.502 & 1.63 & 3.557 & 2.11 & 25.179 & 2.47 & 178.250 & 0.06 & 1261.915 & 0.0 \\
\hline 0.080 & 0.00 & 0.564 & 1.72 & 3.991 & 2.22 & 28.251 & 2.35 & 200.000 & 0.11 & 1415.892 & 0.00 \\
\hline 0.089 & 0.00 & 0.632 & 1.75 & 4.477 & 2.31 & 31.698 & 2.20 & 224.404 & 0.19 & 1588.656 & 0.00 \\
\hline 0.100 & 0.00 & 0.710 & 1.74 & 5.024 & 2.38 & 35.566 & 1.99 & 251.785 & 0.32 & 1782.502 & 0.0 \\
\hline 0.112 & 0.00 & 0.796 & 1.69 & 5.637 & 2.42 & 39.905 & 1.75 & 282.508 & 0.50 & 2000.000 & \\
\hline 0.126 & 0.00 & $\begin{array}{l}0.893 \\
1002\end{array}$ & 1.62 & 6.325 & 2.44 & $\begin{array}{l}44.774 \\
50.238\end{array}$ & 1.49 & 316.979 & 0.72 & & \\
\hline 0.142 & & 1.002 & & 7.096 & & 50.238 & & 355.656 & & & \\
\hline
\end{tabular}

Operator notes: $\quad$ Average of 15 measurements from 53451-TI037.mea

Malvern Instruments Ltd.

Malvern, UK $:=+[441(0) 1684-892456 \mathrm{Fax}+[441$ (0) 168+892789
Mastersizer 2000 Ver, 5.60

Serial Number : MAL1019545
File name: 53451-T1037.mea Record Number: 86 


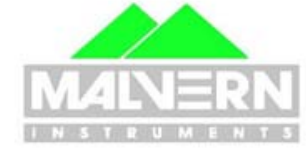

T. STIR U M E N T S

\section{MASTERSIZER 2000}

\section{Result Analysis Report}

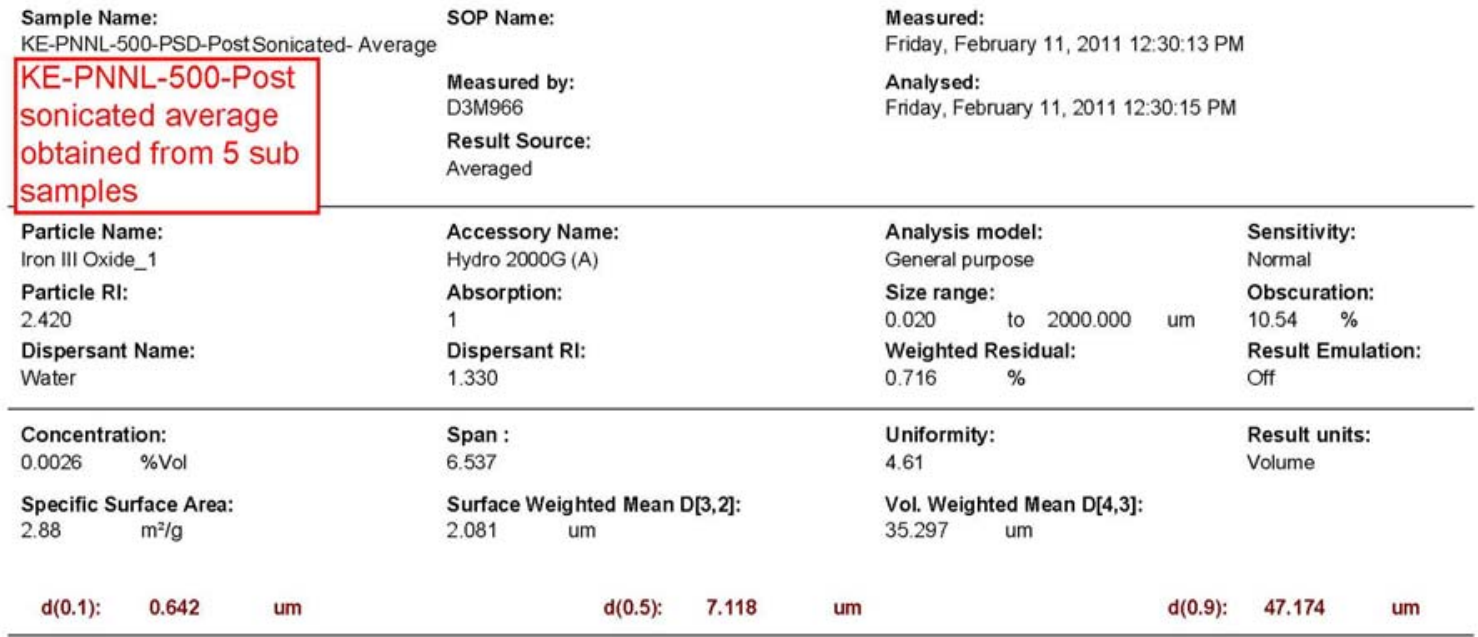

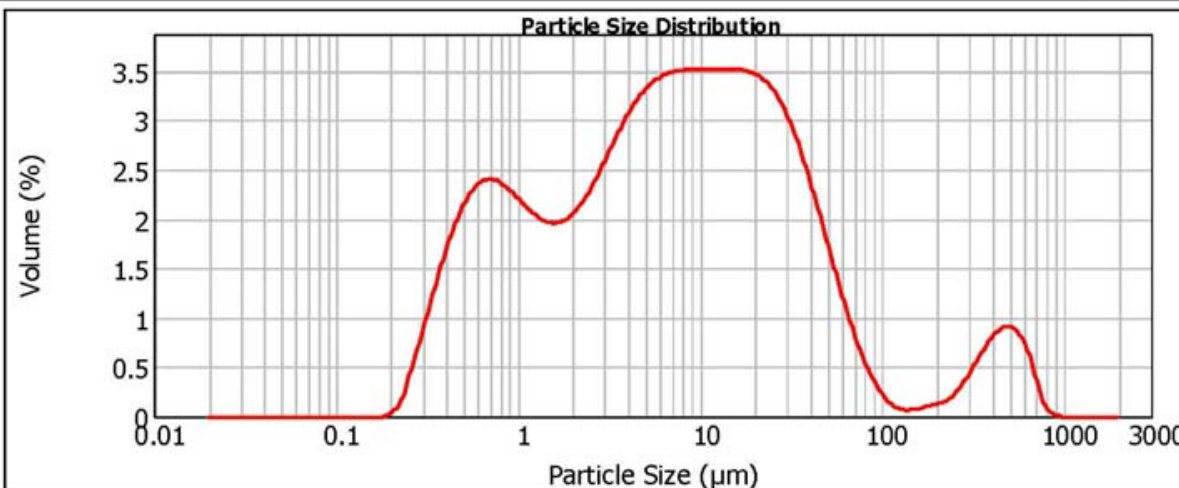

Particle Size $(\mu \mathrm{m})$

\begin{tabular}{|c|c|c|c|c|c|c|c|c|c|c|c|}
\hline Size ( $\mu \mathrm{m})$ & Volume in $\%$ & Size ( $\mu \mathrm{m})$ & Volume In \% & Size (jm) & Volume in $\%$ & Size $(\mu \mathrm{m})$ & Volume In \% & Size $(\mu \mathrm{m})$ & Volume in $\%$ & Size ( $\mu \mathrm{m})$ & Volume $\ln \%$ \\
\hline 0.020 & 0.00 & 0.142 & & 1.002 & & 7,096 & 264 & 50.238 & 118 & 355.656 & 0.55 \\
\hline 0.022 & 0.00 & 0.159 & 0.00 & 1.125 & 1.02 & 7.962 & 2.04 & 56.368 & 1.10 & 399.052 & 0.55 \\
\hline 0.025 & 0.00 & 0.178 & 0.00 & 1.262 & 1.55 & 8.934 & 2.64 & 63.246 & 0.93 & 447.744 & 0.65 \\
\hline 0.028 & 0.00 & 0.200 & 0.01 & 1.416 & 1.50 & 10.024 & 2.65 & 70.963 & 0.71 & 502.377 & 0.69 \\
\hline 0.032 & 0.00 & 0.224 & 0.05 & 1.589 & 1.48 & 11.247 & 2.65 & 79.621 & 0.51 & 563.677 & 0.67 \\
\hline 0.036 & 0.00 & 0.252 & 0.20 & 1.783 & 1.48 & 12.619 & 2.65 & 89.337 & 0.34 & 632456 & 0.58 \\
\hline 0.040 & 0.00 & 0.283 & 0.43 & 2.000 & 1.52 & 14.159 & 2.65 & 100.237 & 0.21 & 709.627 & 0.3 \\
\hline 0.045 & 0.00 & 0.317 & 0.66 & 2.244 & 1.59 & 15.887 & 2.65 & 112.468 & 0.12 & 796.214 & 0.14 \\
\hline 0.050 & 0.00 & 0.356 & 0.91 & 2.518 & 1.69 & 17.825 & 2.64 & 126.191 & 0.06 & 893.367 & 0.03 \\
\hline 0.056 & 0.00 & 0.399 & 1.15 & 2.825 & 1.81 & 20.000 & 2.63 & 141.589 & 0.05 & 1002.374 & 0.00 \\
\hline 0.063 & 0.00 & 0.448 & $\begin{array}{l}1.37 \\
1.55\end{array}$ & 3.170 & $\begin{array}{l}1.95 \\
2.10\end{array}$ & 22.440 & 2.59 & 158.866 & 0.05 & 1124.683 & 0.00 \\
\hline 0.071 & 0.00 & 0.502 & $\begin{array}{l}1.55 \\
1.68\end{array}$ & 3.557 & 2.10 & 25.179 & 2.53 & 178.250 & 0.07 & 1261.915 & 0.0 \\
\hline 0.080 & $\begin{array}{l}0.00 \\
0.00\end{array}$ & 0.564 & $\begin{array}{l}1.68 \\
1.77\end{array}$ & 3.991 & 2.24 & 28.251 & 2.44 & 200.000 & 0.09 & 1415.892 & 0.00 \\
\hline 0.089 & 0.00 & 0.632 & 1.77 & 4.477 & 2.36 & 31.698 & $\begin{array}{r}2.30 \\
2.13\end{array}$ & 224.404 & 0.10 & 1588.656 & 0.00 \\
\hline 0.100 & $\begin{array}{l}0.00 \\
0.00\end{array}$ & 0.710 & $\begin{array}{l}1.81 \\
1.80\end{array}$ & 5.024 & $\begin{array}{l}2.46 \\
2.54\end{array}$ & 35.566 & $\begin{array}{l}2.13 \\
1.92\end{array}$ & 251.785 & 0.14 & 1782.502 & 0.00 \\
\hline 0.112 & 0.00 & 0.796 & $\begin{array}{l}1.80 \\
1.76\end{array}$ & 5.637 & $\begin{array}{l}2.54 \\
2.59\end{array}$ & 39.905 & $\begin{array}{l}1.92 \\
1.68\end{array}$ & 282.508 & 0.22 & 2000.000 & 0.00 \\
\hline 0.126 & 0.00 & 0.893 & 1.70 & 6.325 & 2.62 & 44.774 & 1.43 & 316.979 & 0.44 & & \\
\hline 0.142 & 0.00 & 1.002 & 1.10 & 7.096 & & 50.238 & & 355.656 & & & \\
\hline
\end{tabular}

Operator notes: $\quad$ Average of 15 measurements from 53451-TI037.mea

Malvern Instruments Ltd

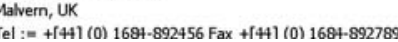

Mastersiner 2000 Ver, 5.60

Serial Number : MAL1019545
File name: 53451-T1037.mea Record Number: 87 


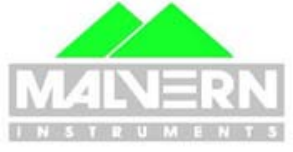
KE-PNNL-FULL-PSD-Unsonicated-Average KE-PNNL-Fullunsonicated average obtained from 2 sub samples

\section{Particle Name:}

Iron III Oxide_1

Particle RI:

2.420

Dispersant Name:

Water

Concentration:

$0.0048 \%$ Vol

Specific Surface Area:

$1.17 \quad \mathrm{~m}^{2} / \mathrm{g}$

$\mathrm{d}(0.1): \quad 1.979$

\section{MASTERSIZER 2000}

\section{Result Analysis Report}

SOP Name:

Measured by:

D3M966

Result Source:

Averaged
Measured:

Friday, February 11, 2011 1:23:57 PM

Analysed:

Friday, February 11, 2011 1:23:59 PM

\begin{tabular}{llllllll}
$d(0.1):$ & 1.979 & um & $d(0.5):$ & 31.814 & um & $d(0.9):$ & 344.039 \\
\hline
\end{tabular}

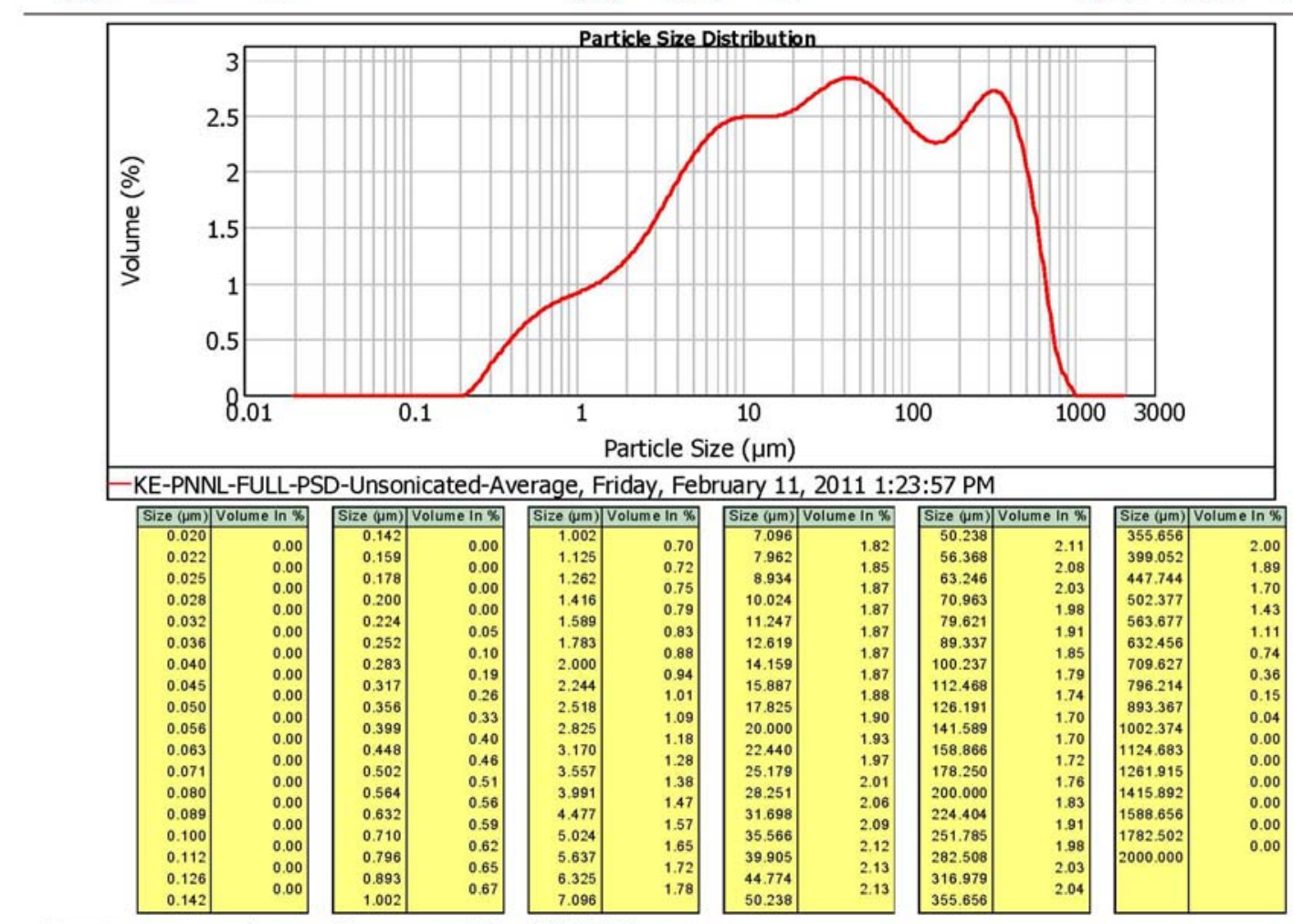

Accessory Name:

Hydro 2000G (A)

Absorption:

Dispersant RI:

1.330

Span :

10.752

Surface Weighted Mean D[3,2]:

5.124 um

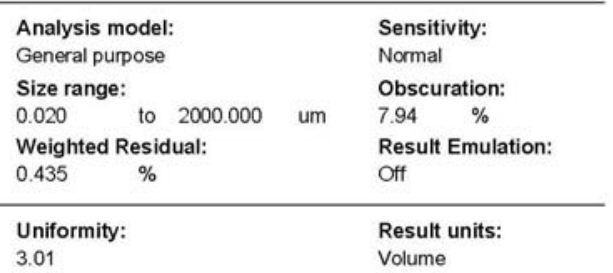

Vol. Weighted Mean D[4,3]:

105.651 um

Operator notes: $\quad$ Average of 6 measurements from 53451-T1037.mea

Malvern Instruments Ltd

Malvern, UK
Tel : $=+\lceil 441(0) 1684-892456 \mathrm{Fax}+[441(0) 168+892789$
Mastersizer 2000 Ver, 5.60

Serial Number : MAL1019545
File name: 53451-T1037.mea Record Number: 88 


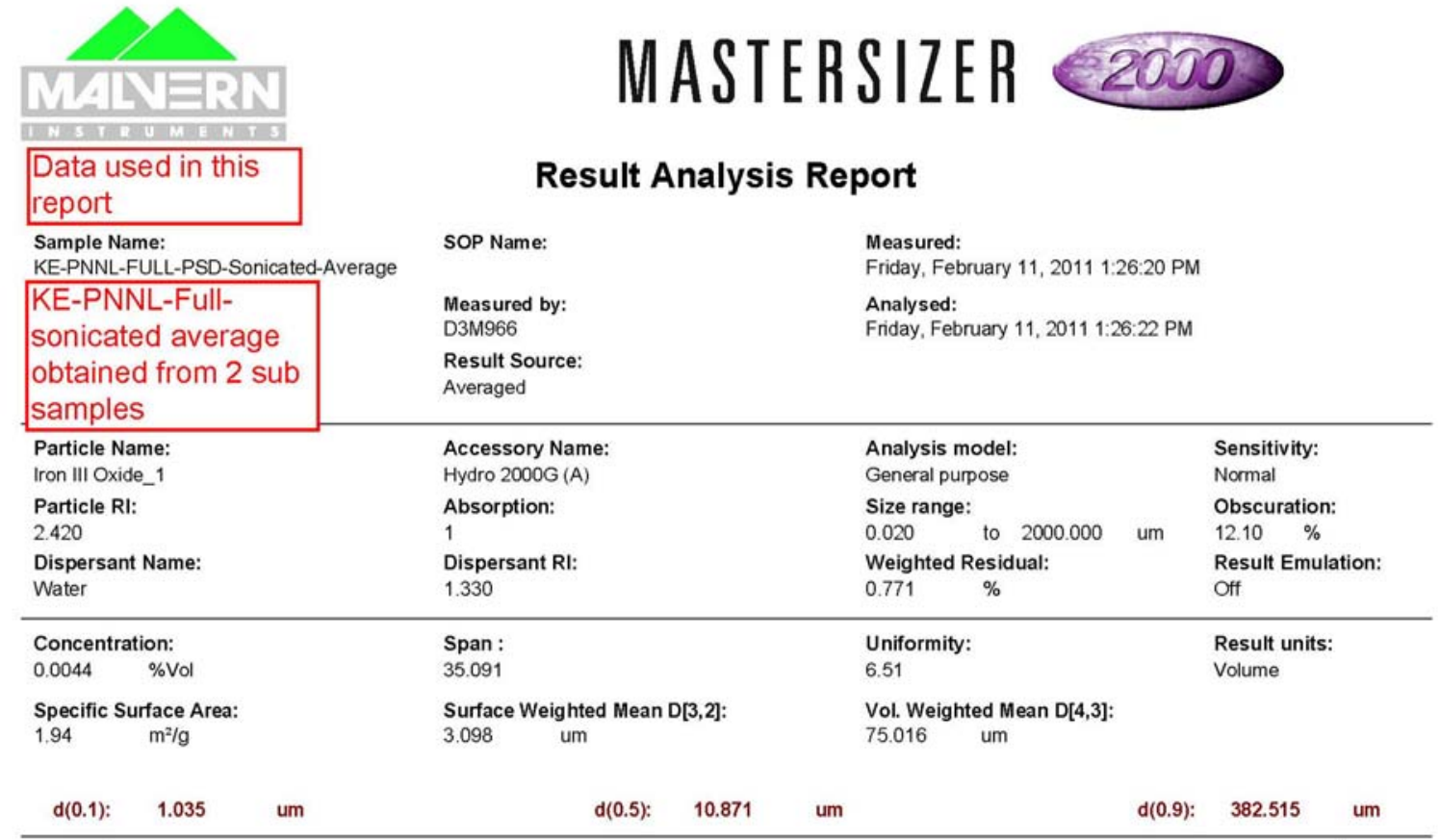

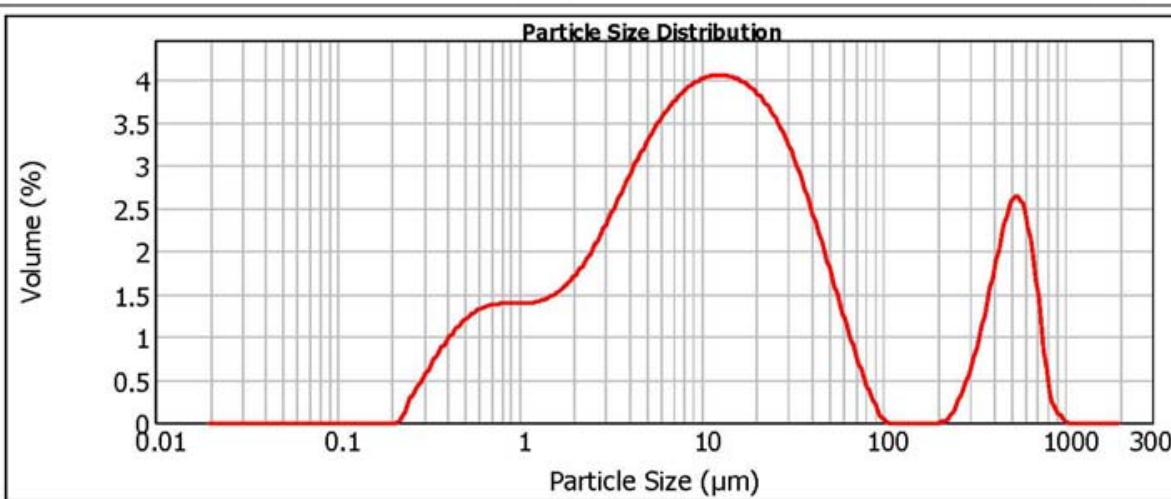

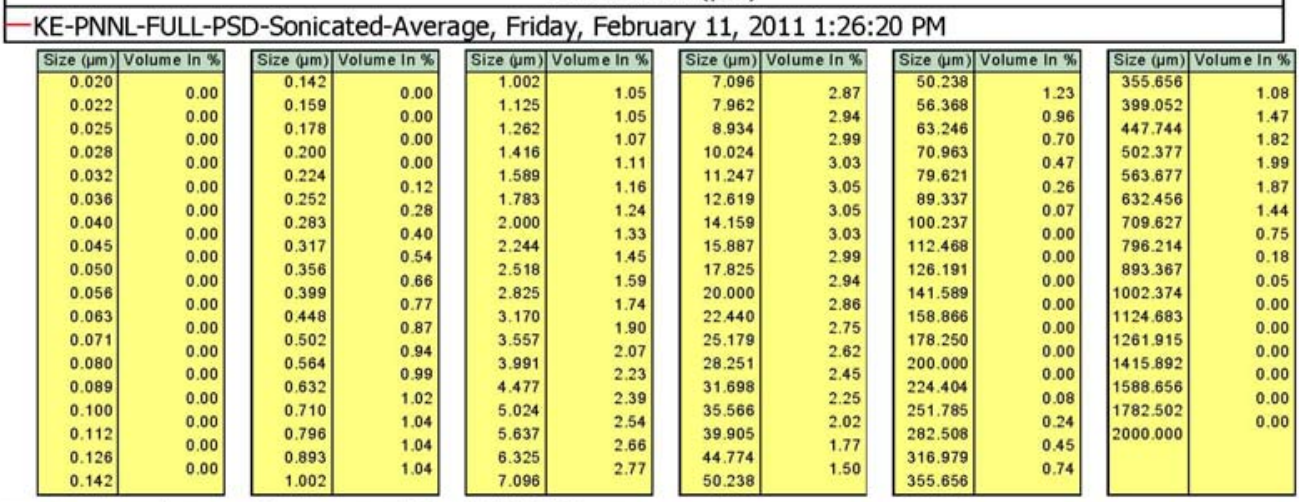

Operator notes: $\quad$ Average of 6 measurements from 53451-TIO37.mea

Malvern Instruments Lod Malvern, UK

Tel := +[441 (0) 1684-892456 Fax +[441 (0) 1684-892789
Mastersizer 2000 Ver. 5.60 Serial Number : MAL1019545
File name: 53451 - 11037 mea Record Number: 89 $211 / 2011820.55 \mathrm{PM}$ 


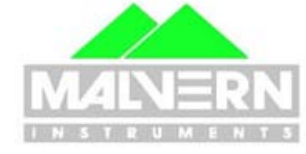

HWS T U M ENTS

\section{MASTERSIZER 2000}

\section{Result Analysis Report}

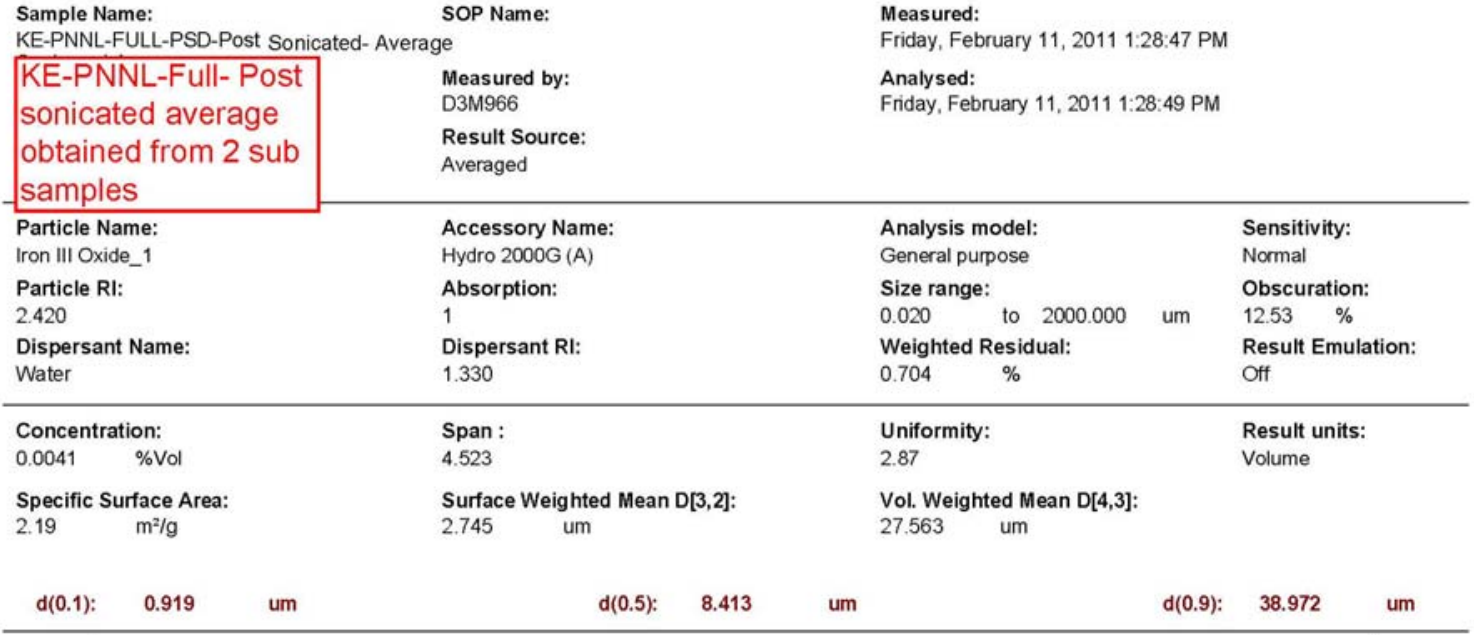

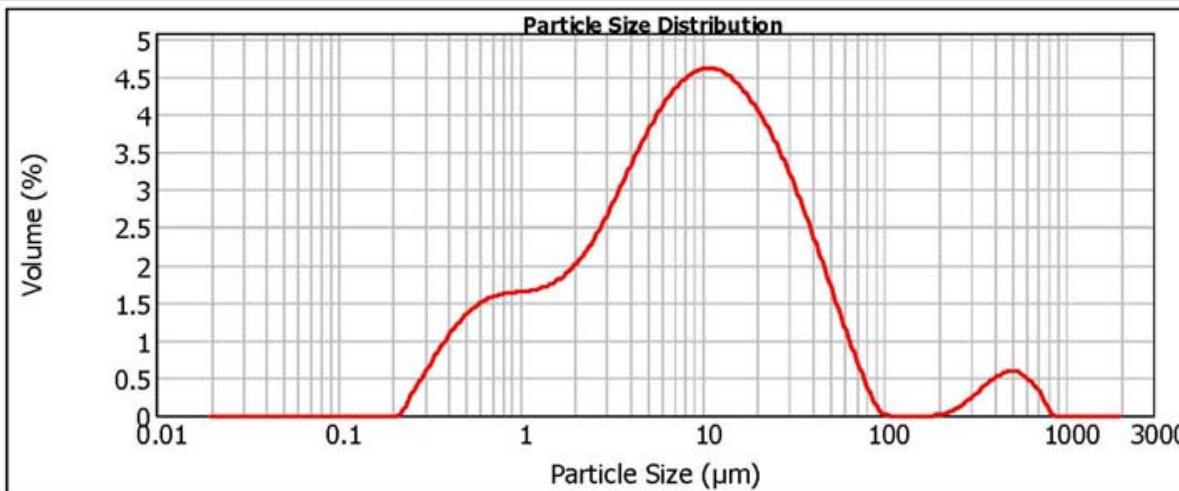

Particle Size ( $\mu \mathrm{m})$

\begin{tabular}{|c|c|c|c|c|c|c|c|c|c|c|c|}
\hline Size ( $\mu \mathrm{m})$ & Volume in $\%$ & Size ( $\mu \mathrm{m})$ & Volume in $\%$ & Size (um) & Volume In $\%$ & Size ( $\mu \mathrm{m})$ & Volume In $\%$ & Size $(\mu \mathrm{m})$ & Volume in $\%$ & Size ( $\mu \mathrm{m})$ & Volume in $\%$ \\
\hline 0.020 & 0 & 0.142 & 0,00 & 1.002 & 124 & 7.096 & 3.32 & 50.238 & 1,17 & 355.656 & 0.33 \\
\hline 0.022 & 0.000 & 0.159 & 0.00 & 1.125 & 1.26 & 7.962 & $\begin{array}{l}3.32 \\
3.40\end{array}$ & 56.368 & 091 & 399.052 & 0.40 \\
\hline 0.025 & 0.00 & 0.178 & 0.00 & 1.262 & 1.28 & 8.934 & $\begin{array}{l}3.40 \\
3.45\end{array}$ & 63.246 & 0.66 & 447.744 & $\begin{array}{l}0.40 \\
0.44\end{array}$ \\
\hline 0.028 & 0.00 & 0.200 & 0.00 & 1.416 & 1.32 & 10.024 & 3.47 & 70.963 & 0.43 & 502.377 & 0.44 \\
\hline 0.032 & 0.00 & $\begin{array}{l}0.224 \\
0.252\end{array}$ & 0.12 & $\begin{array}{l}1.589 \\
1.783\end{array}$ & 1.38 & $\begin{array}{l}11.247 \\
12819\end{array}$ & 3.46 & 79.621 & 0.20 & 563.677 & 0.38 \\
\hline $\begin{array}{l}0.036 \\
0.040\end{array}$ & 0.00 & $\begin{array}{l}0.252 \\
0.283\end{array}$ & 0.29 & $\begin{array}{l}1.783 \\
2.000\end{array}$ & 1.46 & $\begin{array}{r}12.619 \\
14.159\end{array}$ & 3.42 & $\begin{array}{r}89.337 \\
100.237\end{array}$ & 0.04 & 632.456 & 0.30 \\
\hline $\begin{array}{l}0.040 \\
0.045\end{array}$ & 0.00 & 0.317 & 0.42 & 2.244 & 1.56 & $\begin{array}{l}14.159 \\
15.897\end{array}$ & 3.35 & 112468 & 0.00 & 709.627 & 0.1 \\
\hline $\begin{array}{l}0.045 \\
0.050\end{array}$ & 0.00 & 0.356 & 0.58 & 2.518 & 1.68 & $\begin{array}{l}15.887 \\
117.895\end{array}$ & 3.25 & 112.468 & 0.00 & 796.214 & 0.0 \\
\hline 0.056 & 0.00 & 0.399 & 0.72 & 2.825 & 1.83 & 20000 & 3.13 & 141.589 & 0.00 & 893.367 & 0.0 \\
\hline 0.063 & 0.00 & 0.448 & 0.85 & 3.170 & 2.00 & $\begin{array}{l}20.000 \\
22440\end{array}$ & 2.99 & 158.866 & 0.00 & $\begin{array}{l}102.374 \\
1124683\end{array}$ & 0.00 \\
\hline 0.071 & 0.00 & 0.502 & 0.96 & 3.557 & 2.19 & 25.179 & 2.82 & 178.250 & 0.00 & 1261.915 & 0.0 \\
\hline 0.080 & $\begin{array}{l}0.00 \\
0.00\end{array}$ & 0.564 & $\begin{array}{l}1.05 \\
1.12\end{array}$ & 3.991 & $\begin{array}{l}2.38 \\
2.57\end{array}$ & 28.251 & 2.64 & 200.000 & 0.00 & 1415.892 & 0. \\
\hline 0.089 & 0.00 & 0.632 & 1.1 .17 & 4.477 & $\begin{array}{l}2.37 \\
276\end{array}$ & 31.698 & 2.43 & 224.404 & 0.05 & 1588.656 & 0.00 \\
\hline 0.100 & 0.00 & 0.710 & 1.20 & 5.024 & 2.93 & 35.566 & 1.97 & 251.785 & 0.10 & 1782.502 & 0.00 \\
\hline 0.112 & 0.00 & 0.796 & 1.22 & 5.637 & 3.08 & 39.905 & 1.71 & 282.508 & 0.17 & & \\
\hline $\begin{array}{l}0.126 \\
0.142\end{array}$ & 0.00 & $\begin{array}{l}0.893 \\
1.002\end{array}$ & 1.23 & $\begin{array}{l}6.325 \\
7.096\end{array}$ & 3.21 & $\begin{array}{l}44.774 \\
50.238\end{array}$ & 1.45 & $\begin{array}{r}316.979 \\
355.656\end{array}$ & 0.25 & & \\
\hline
\end{tabular}

Operator notes: $\quad$ Average of 6 measurements from 53451-TIO37.mea

Malvern Instruments Lod

Malvern, UK

Tel : $=+[441$ (0) 1684-892456 Fax +[441 (0) 168+-892789
Mastersizer 2000 Ver. 5.60 Serial Number : MAL1019545
File name: 53451-T1037.mea Record Number: 90 2/11/2011 820:56 PM 


\section{Appendix C}

Shear Strength vs. Time and Rheograms (Yield Stress and Viscosity Plots) 


\section{Appendix C: Rheology Plots}

Shear-strength values were obtained from stress/time profiles that are given in this appendix. The flow curves used to obtain yield stress and viscosity values for both KW and KE simulants are also included along with their corresponding viscosity plots. Triplicate analysis was performed on the settler and KW-B M500 simulants and 5 measurements were performed at both 20 and $30{ }^{\circ} \mathrm{C}$ for the KE-PNNL500 simulant. All data have been discussed and summarized in Section 3.3. 


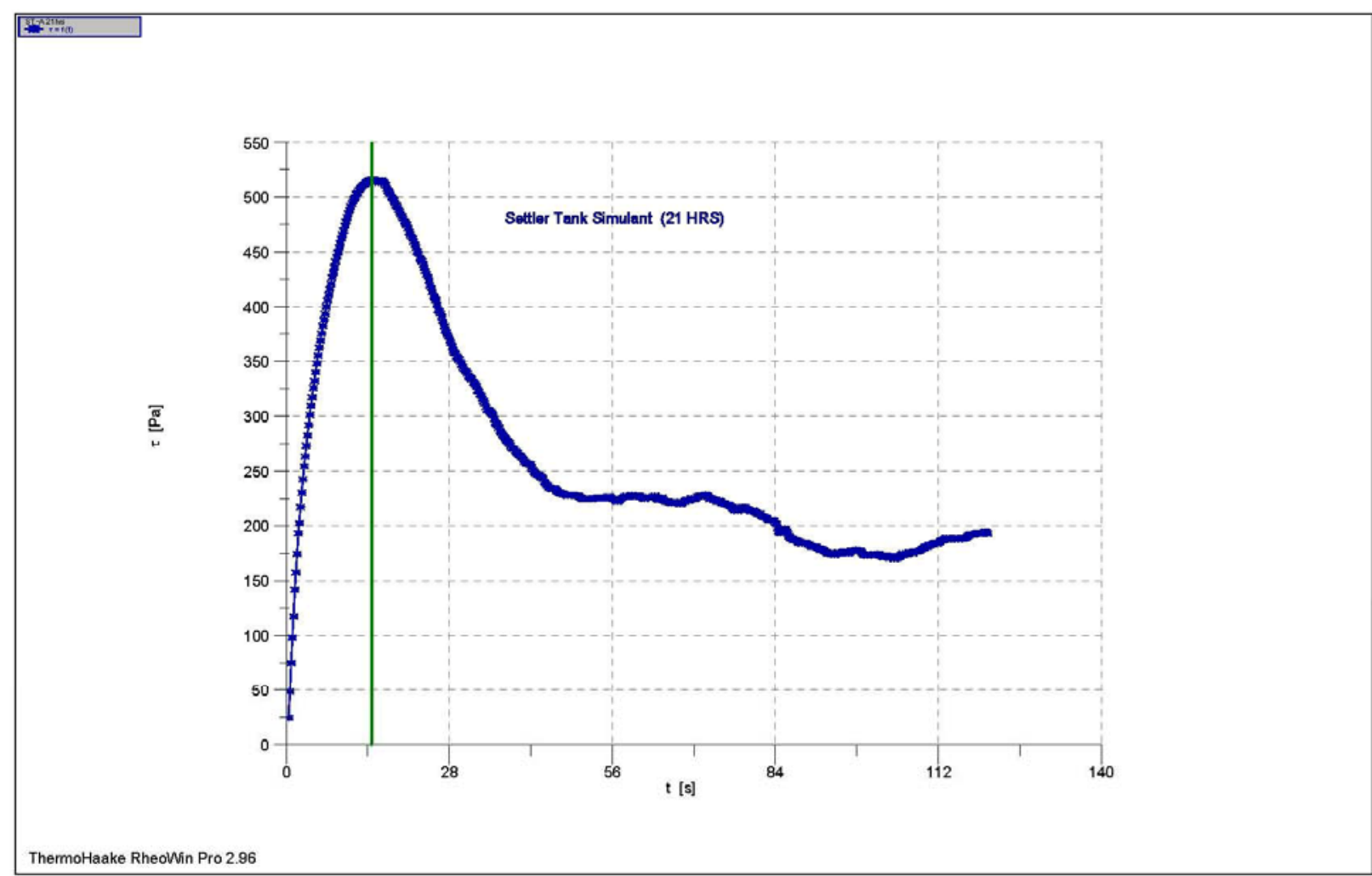

1: C: IRheologv Results $153019-\mathrm{M} 12 \mathrm{IShear}$ Strength $1.6 \times 1.6 \mathrm{~cm}$ VanelST -A $21 \mathrm{hrs} . \mathrm{rwd}$ Company / Operator: PNNL / MARIA LUNA

Date / Time / Version: 03.03.2009 / 13:04:34 PM / RheoWin Pro 296

Substance / Sample no: 090303 Settler Tank Simulant $21 \mathrm{hrs} / \mathrm{ST}-\mathrm{A} 21 \mathrm{hrs}$

Curve discussion: Greatest value $\mathrm{t}[\mathrm{s}] 14.67 \tau[\mathrm{Pa}] 516.4$ 
ThermoHaake RheoWin 3/11/2009/3:28 PM

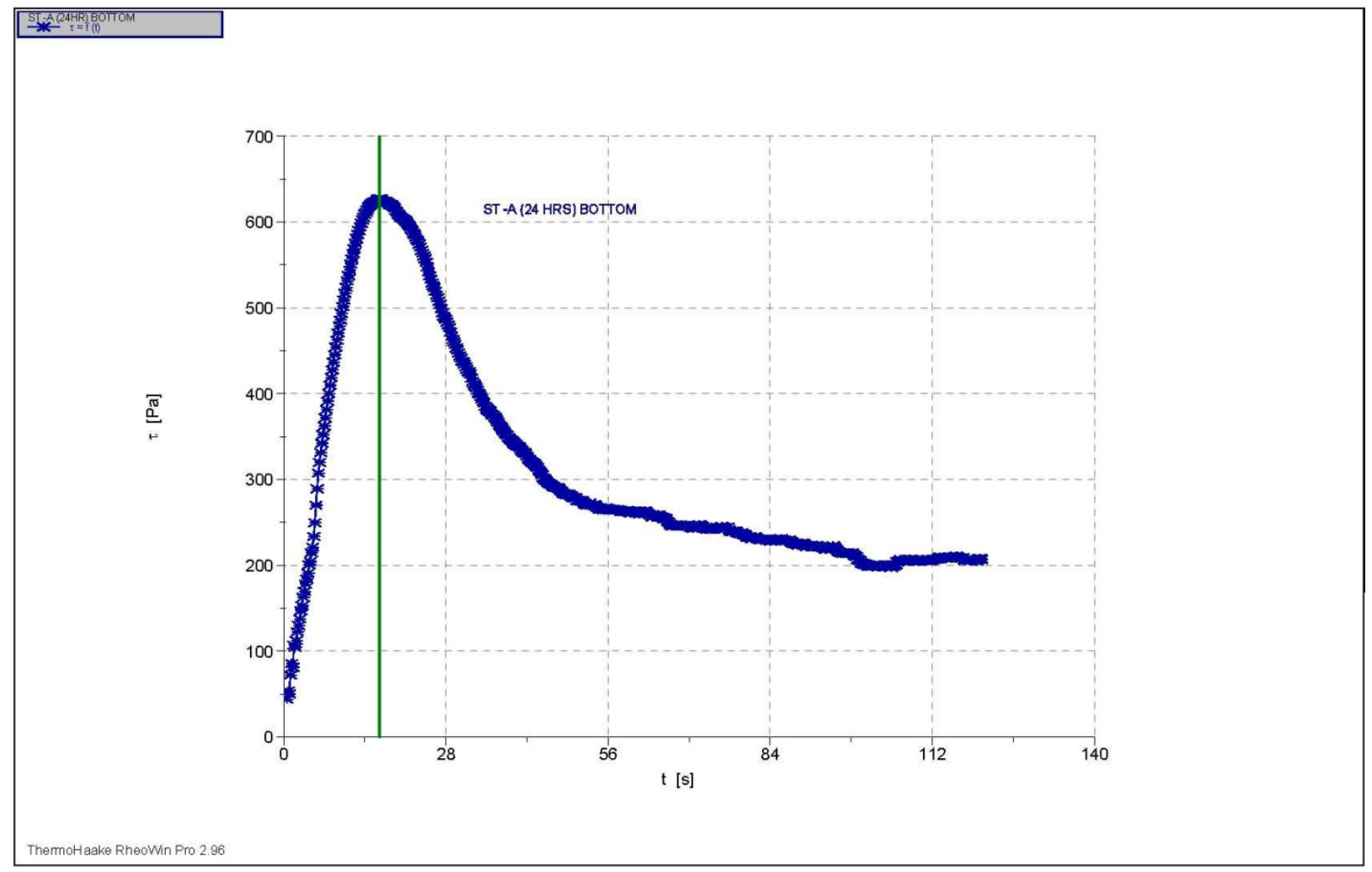

1: C:IRheologv Results|K-Basin IShear Strength (vane)IST -A (24HR) BOTTOM.rwd Company / Operator: PNNL / MARIA LUNA

Date / Time / Version: 11.03.2009 / 15:24:28 PM / RheoWin Pro 296

Substance / Sample no: ST-A (24HR) / ST-A (24HR)

Curve discussion: Greatest value $\mathrm{t}[\mathrm{s}] 16.56 \tau[\mathrm{Pa}] 627.3$ 
ThermoHaake RheoWin 3/5/2009 / 4:11 PM

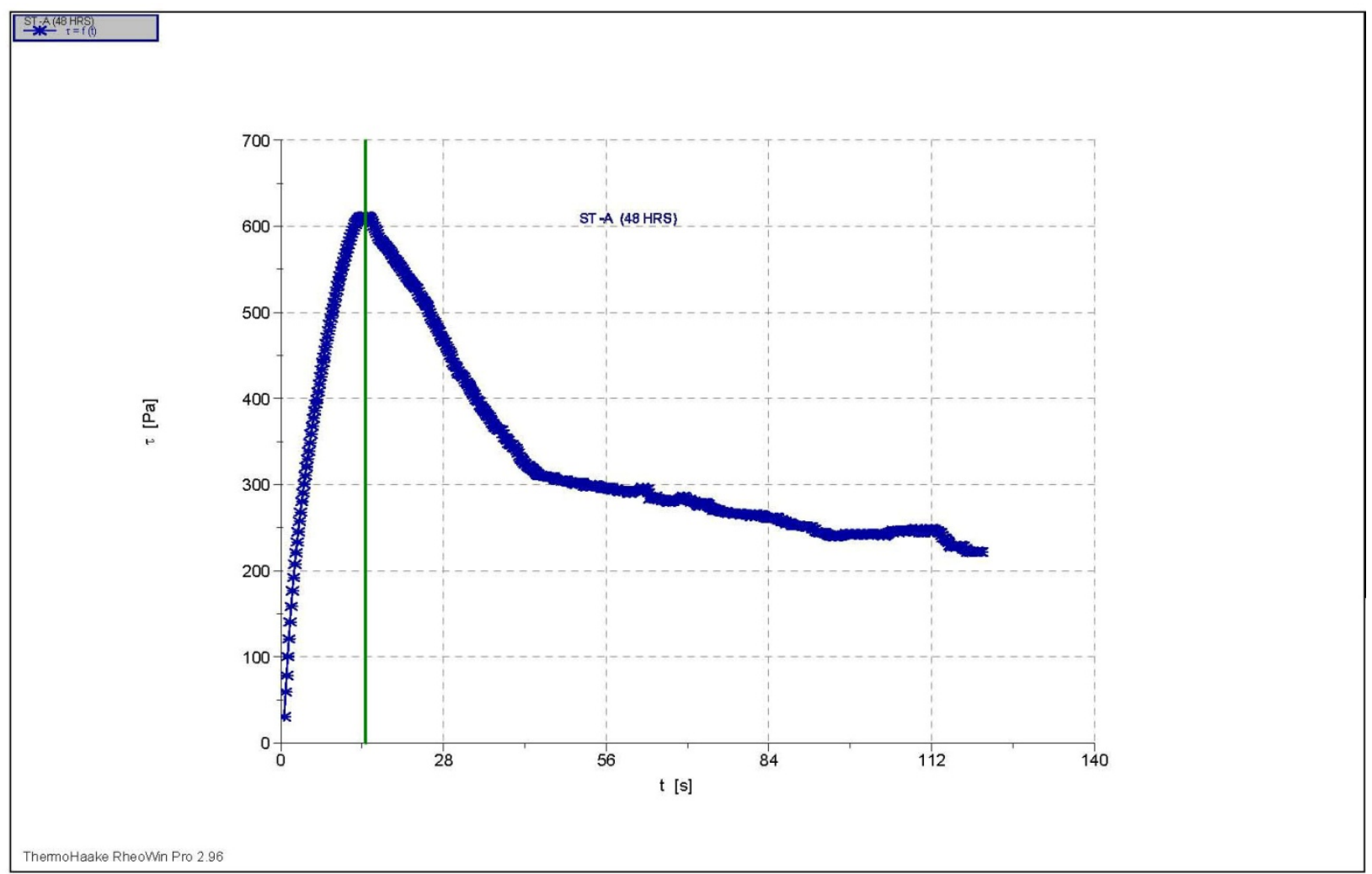

1: C:IRheologv Results153019-M12IShear Strength 1.6 X $1.6 \mathrm{~cm}$ VanelST -A (48 HRS).rwd Company / Operator: PNNL / MARIA LUNA

Date / Time / Version: 05.03.2009 / 15:58:51 PM / RheoWin Pro 296

Substance / Sample no: ST-A (48 HRS) / ST -A (48 HRS)

Curve discussion: Greatest value $\mathrm{t}[\mathrm{s}] 14.60 \tau[\mathrm{Pa}] 612.4$ 
ThermoHaake RheoWin 3/9/2009 / 12:54 PM

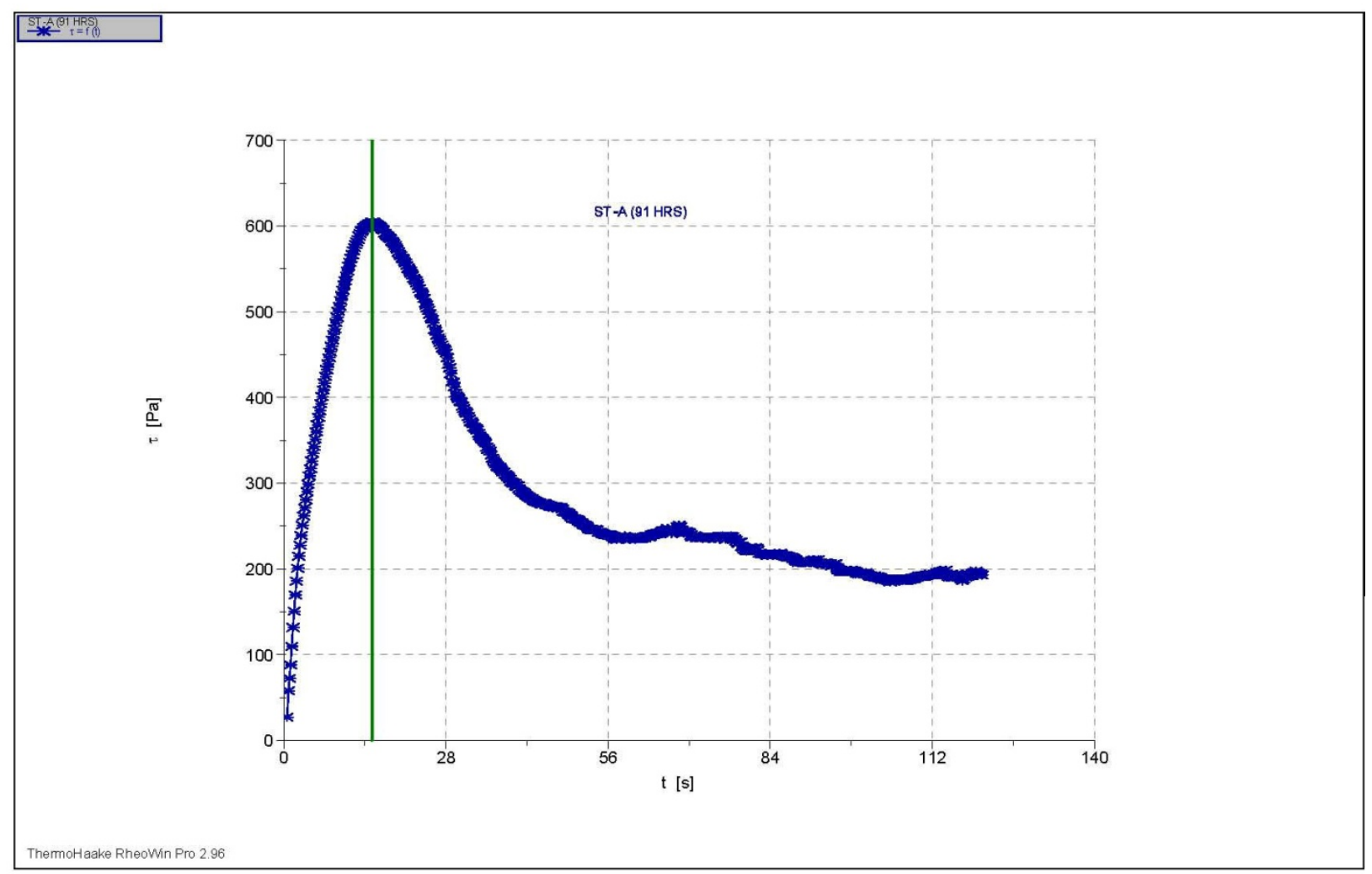

1: C:IRheologv Results 53019 -M12IShear Strength 1.6 X $1.6 \mathrm{~cm}$ VanelST-A (91 HRS).rwd Company / Operator: PNNL / MARIA LUNA

Date / Time / Version: 09.03.2009 / 12:47:34 PM / RheoWin Pro 296

Substance / Sample no: ST-A (91 HRS) / ST-A (91 HRS)

Curve discussion: Greatest value $\mathrm{t}[\mathrm{s}] 15.22 \tau[\mathrm{Pa}] 604.3$ 
ThermoHaake RheoWin 3/9/2009 / 4:33 PM

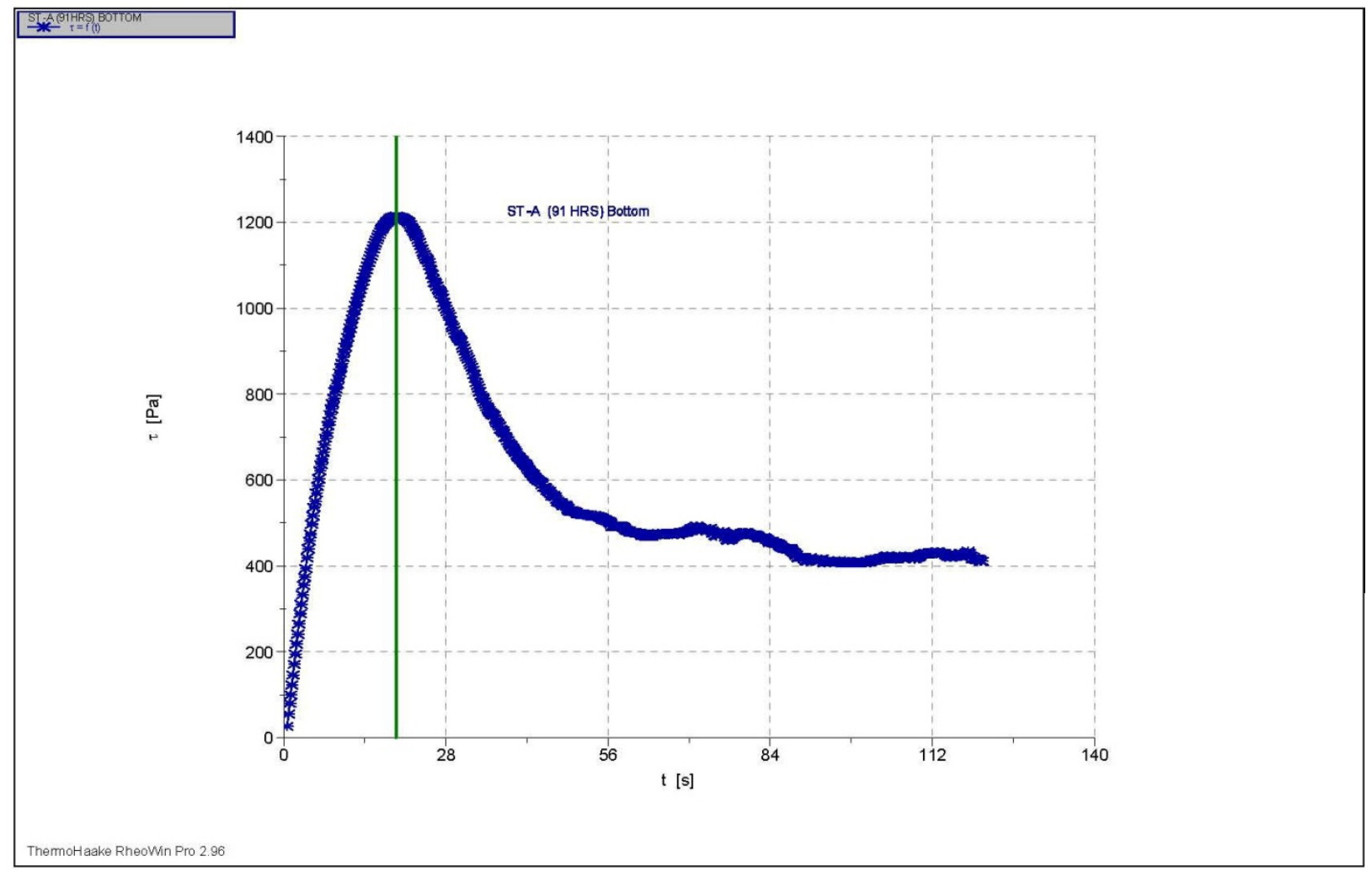

1: C:IRheologv Results|K -BasinIShear Strength (vane)IST -A (91HRS) BOTTOM.rwd Company / Operator: PNNL / MARIA LUNA

Date / Time / Version: 09.03.2009 / 15:11:11 PM / RheoWin Pro 296

Substance / Sample no: ST-A (91HRS) BOTTOM / ST-A (91HRS) BOTTOM

Curve discussion: Greatest value $\mathrm{t}[\mathrm{s}] 19.40 \tau[\mathrm{Pa}] 1214$. 
ThermoHaake RheoWin 3/3/2009 / 1:15 PM

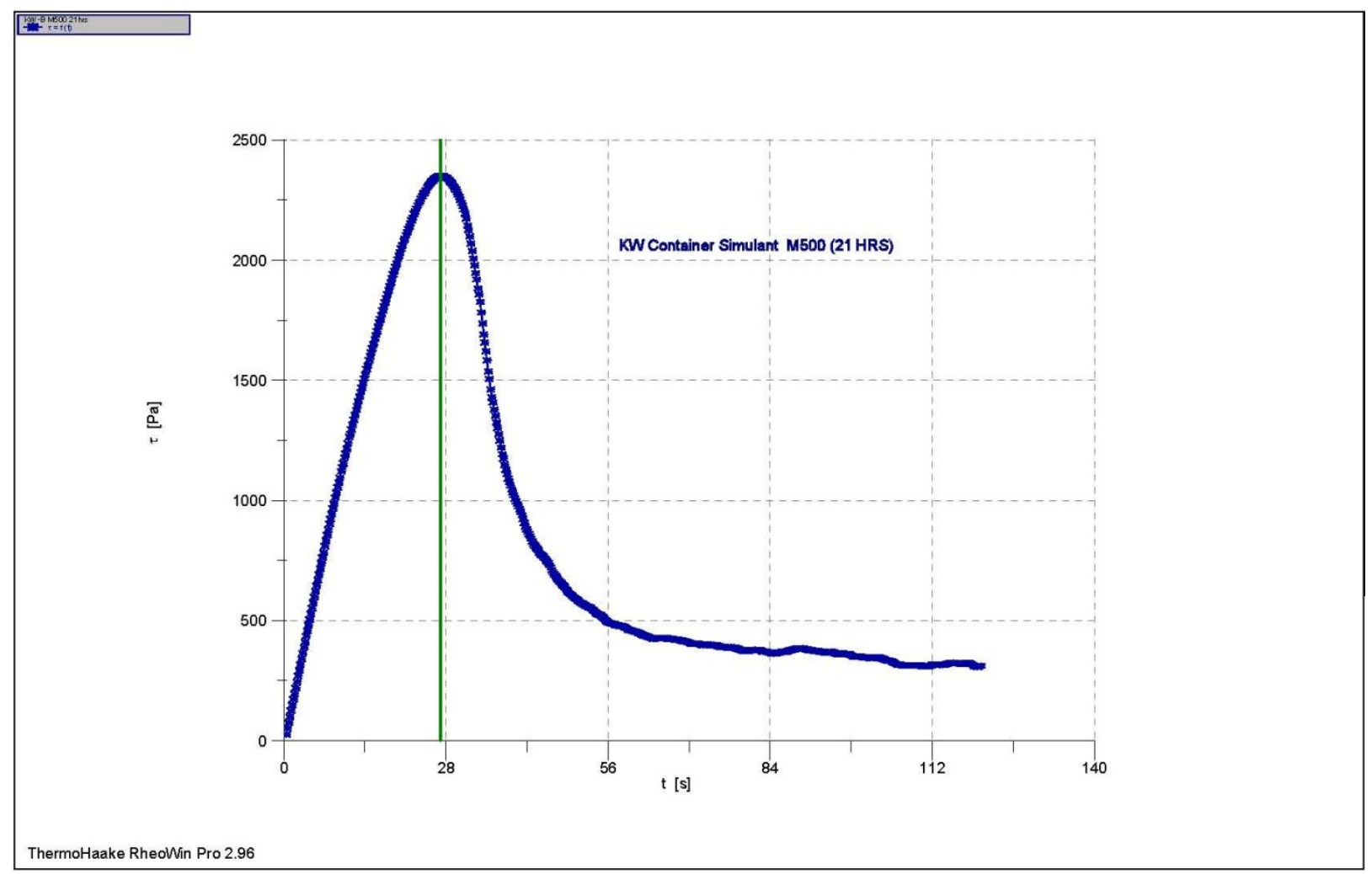

1: C:IRheologv Results $153019-M 121 S h e a r$ Strength $1.6 \times 1.6 \mathrm{~cm}$ Vane $\mid \mathrm{KW}-\mathrm{B}$ M500 21hrs.rwd Company / Operator: PNNL / MARIA LUNA

Date / Time / Version: 03.03.2009 / 13:09:22 PM / RheoWin Pro 296

Substance / Sample no: 090303 KW Container Simulant 21 hrs / KW-B M500 21hrs

Curve discussion: Greatest value $\mathrm{t}[\mathrm{s}] 27.08 \tau[\mathrm{Pa}] 2350$. 
ThermoHaake RheoWin 3/5/2009/ 10:49 AM

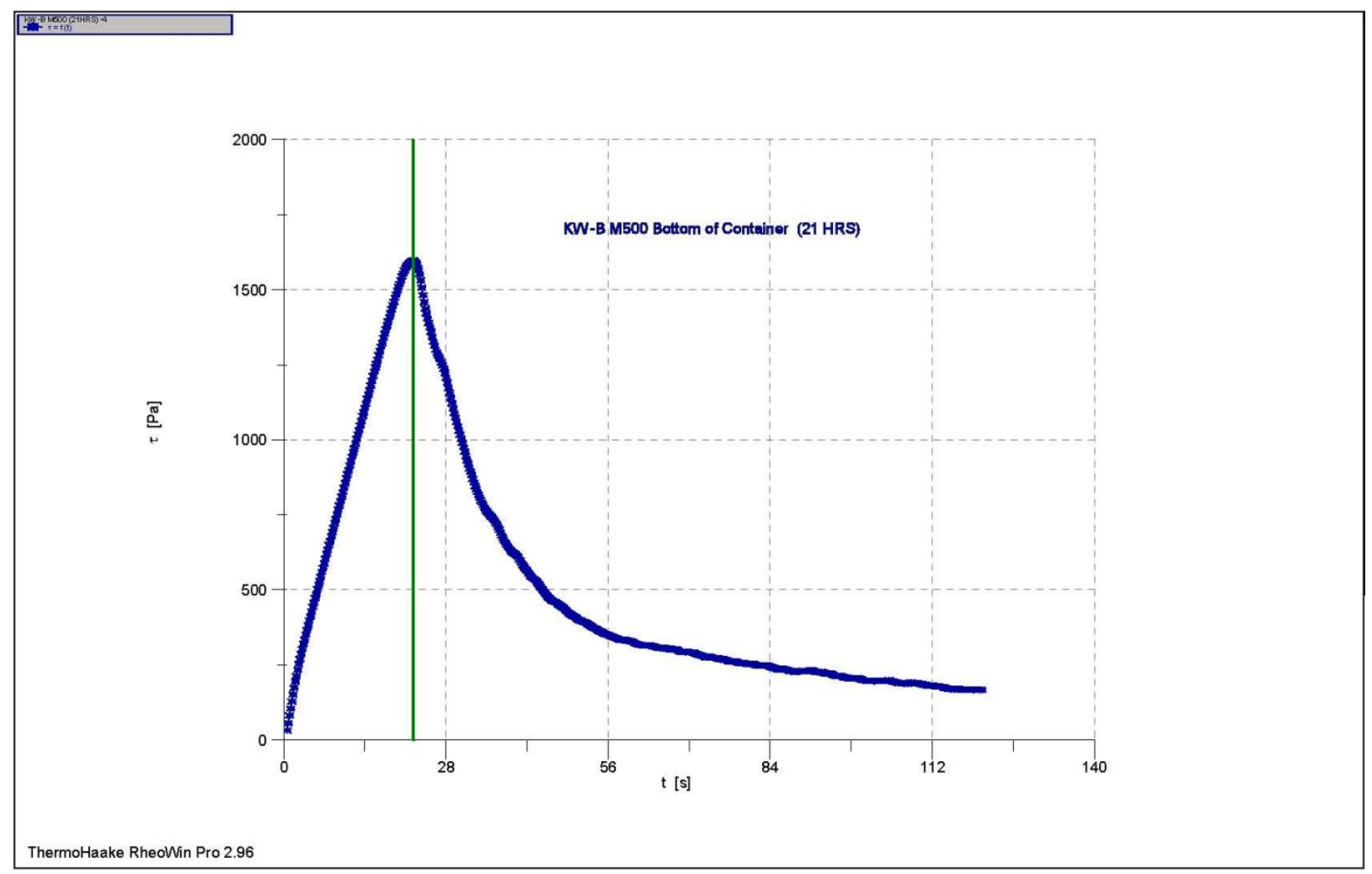

1: C:IRheologv Results153019-M12IShear Strength 1.6 X $1.6 \mathrm{~cm}$ VanelKW-B M500 (21HRS) -4.rwd Company / Operator: PNNL / MARIA LUNA

Date / Time / Version: 05.03.2009 / 10:44:15 AM / RheoWin Pro 296

Substance / Sample no: KW-B M500 (21 HRS) -4 / KW-B M500 (21HRS) -4

Curve discussion: Greatest value $\mathrm{t}[\mathrm{s}] 22.38 \tau[\mathrm{Pa}] 1597$. 
ThermoHaake RheoWin 3/6/2009 / 12:04 PM

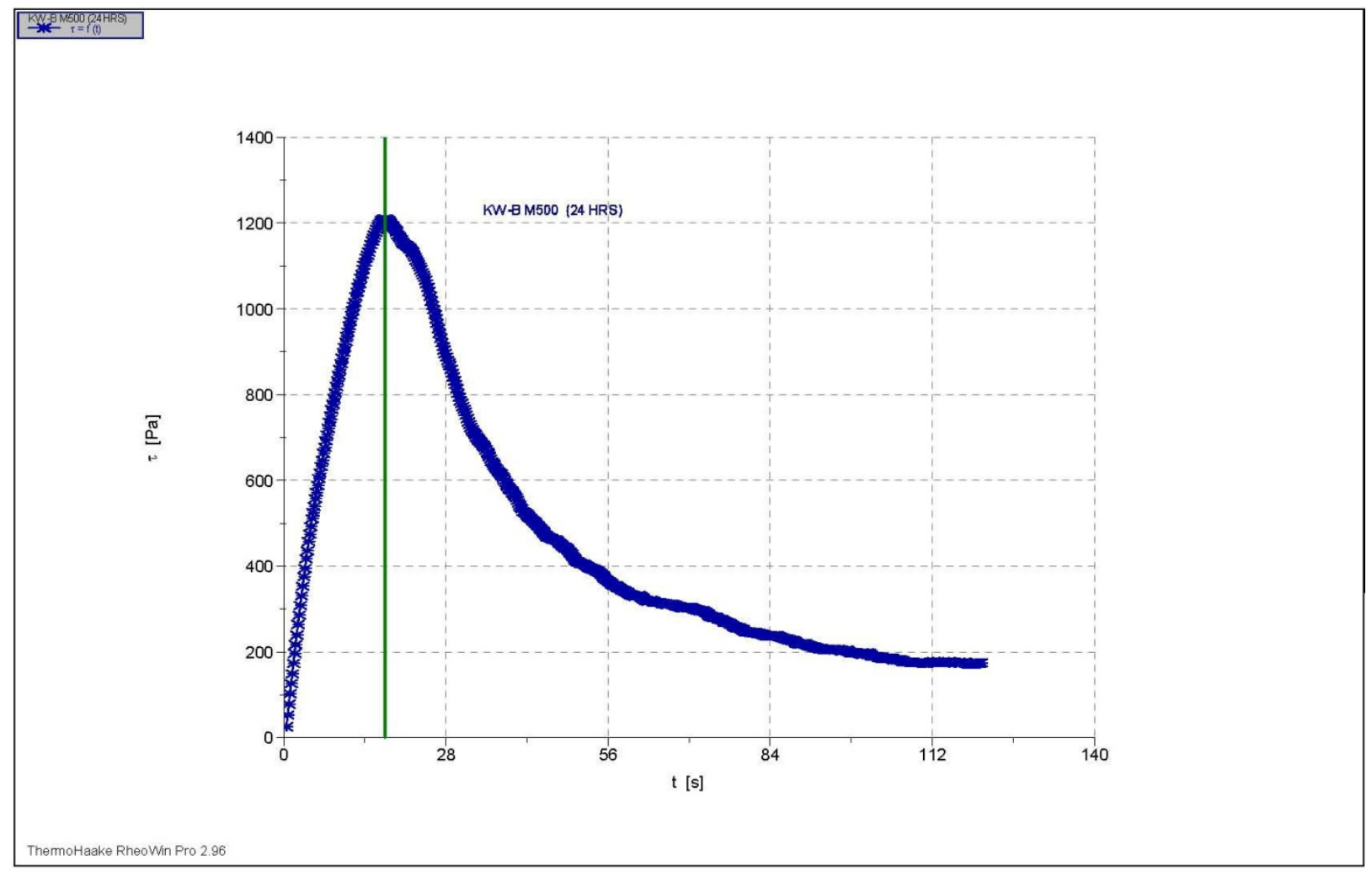

1: C:IRheologv Results $\backslash K$-Basin IShear Strength (vane) \KW-B M500 (24HRS).rwd Company / Operator: PNNL / MARIA LUNA

Date / Time / Version: 06.03.2009 / 11:59:28 AM / RheoWin Pro 296

Substance / Sample no: KW-B M500 (24HRS) / KW-B M500 (24HRS)

Curve discussion: Greatest value $\mathrm{t}[\mathrm{s}] 17.49 \tau[\mathrm{Pa}] 1209$. 
ThermoHaake RheoWin 3/11/2009/3:43 PM

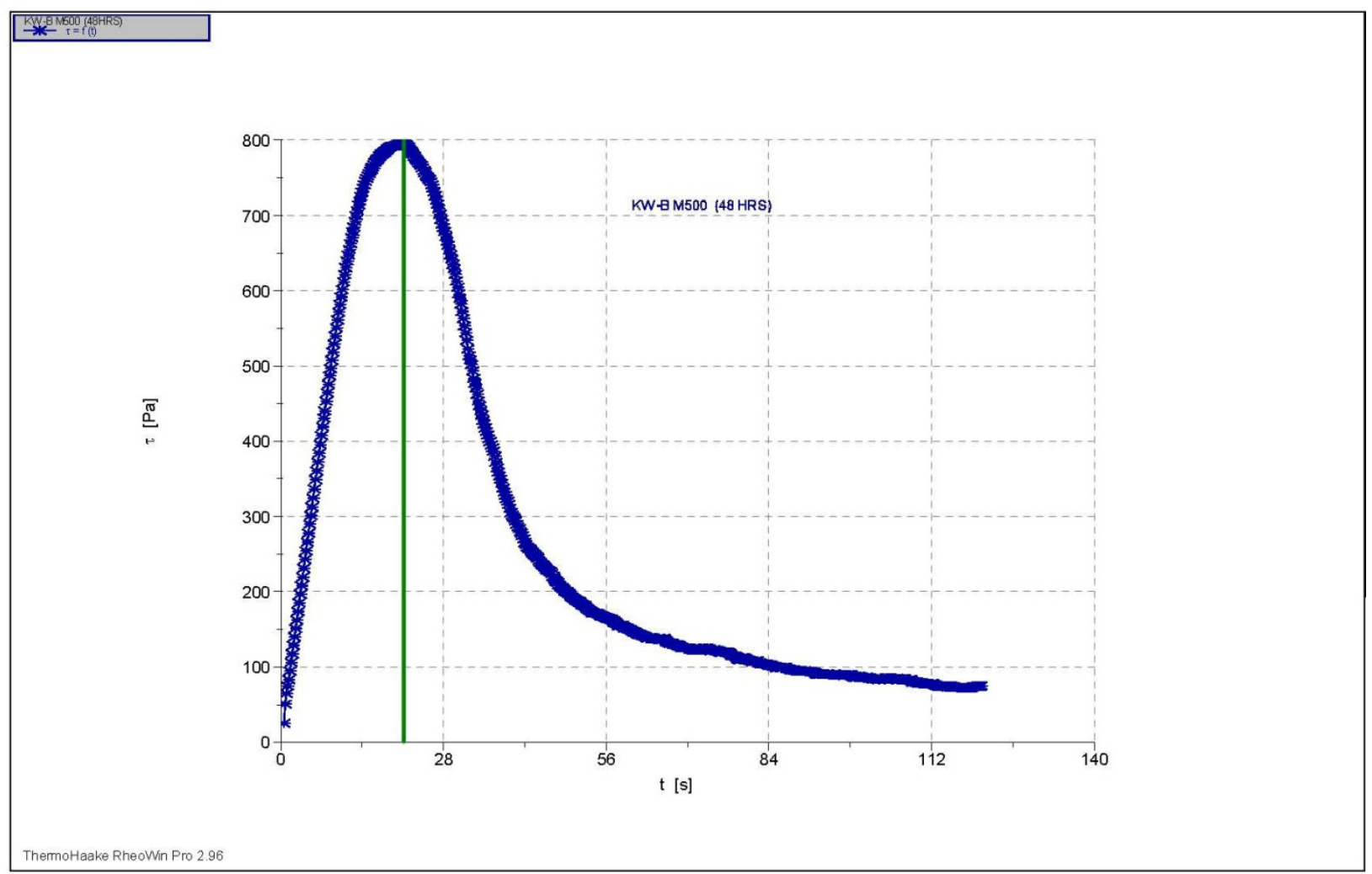

1: C:IRheologv Results \K-Basin IShear Strength (vane)|KW-B M500 (48HRS).rwd

Company / Operator: PNNL / MARIA LUNA

Date / Time / Version: 11.03.2009 / 15:34:44 PM / RheoWin Pro 296

Substance / Sample no: KW-B M500 (48HRS) / KW-B M500 (48HRS)

Curve discussion: Greatest value $\mathrm{t}[\mathrm{s}] 21.19 \tau[\mathrm{Pa}] 797.4$ 


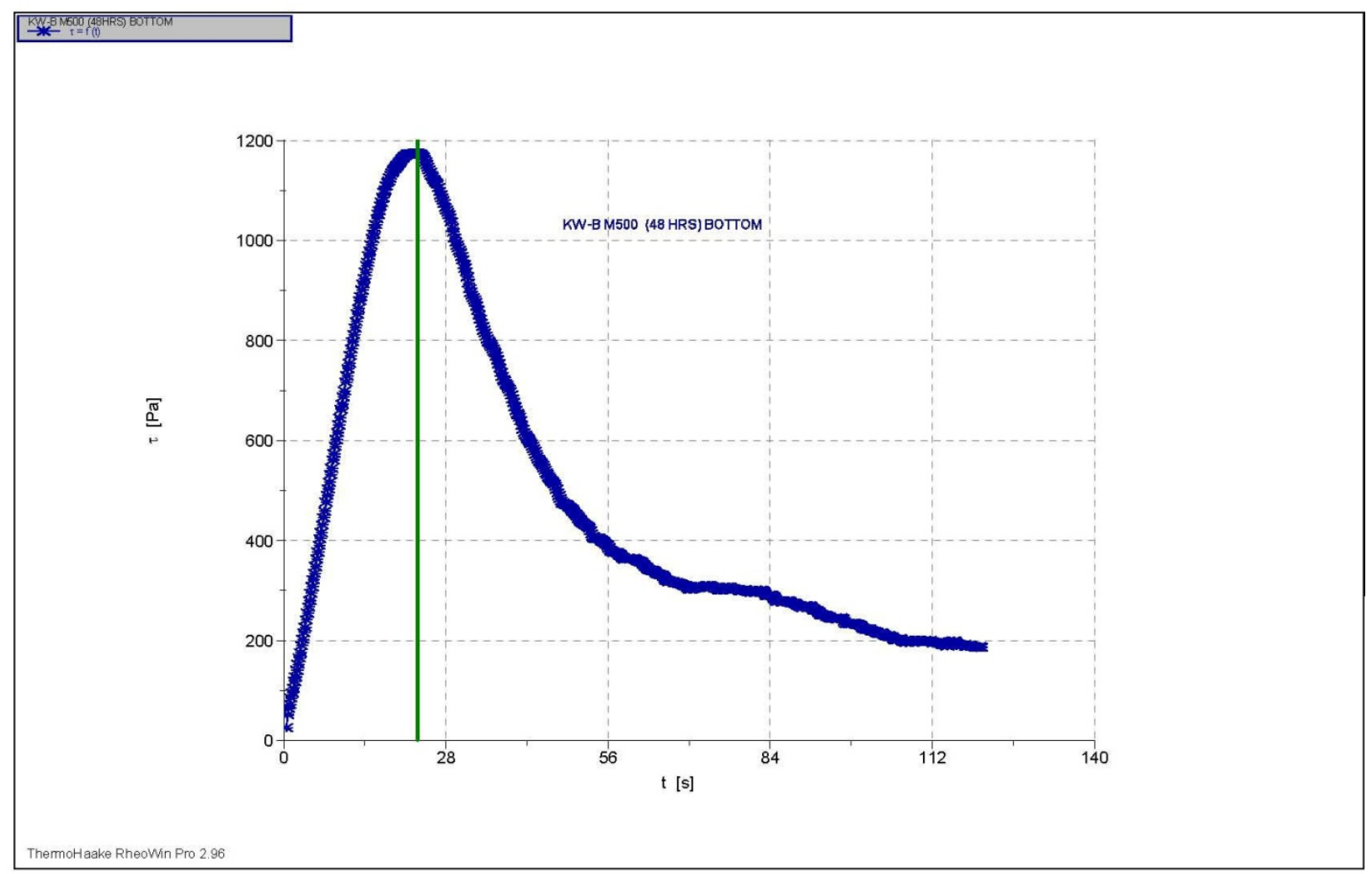

1: C:IRheologv ResultsIK -Basin IShear Strength (vane)|KW-B M500 (48HRS) BOTTOM.rwd Company / Operator: PNNL / MARIA LUNA

Date / Time / Version: 11.03.2009 / 15:38:25 PM / RheoWin Pro 296

Substance / Sample no: KW-B M500 (48HRS) BOTTOM / KW-B M500 (48HRS) BOTTOM

Curve discussion: Greatest value $\mathrm{t}[\mathrm{s}] 23.12 \tau[\mathrm{Pa}] 1174$. 
ThermoHaake RheoWin 3/16/2009 / 9:05 AM

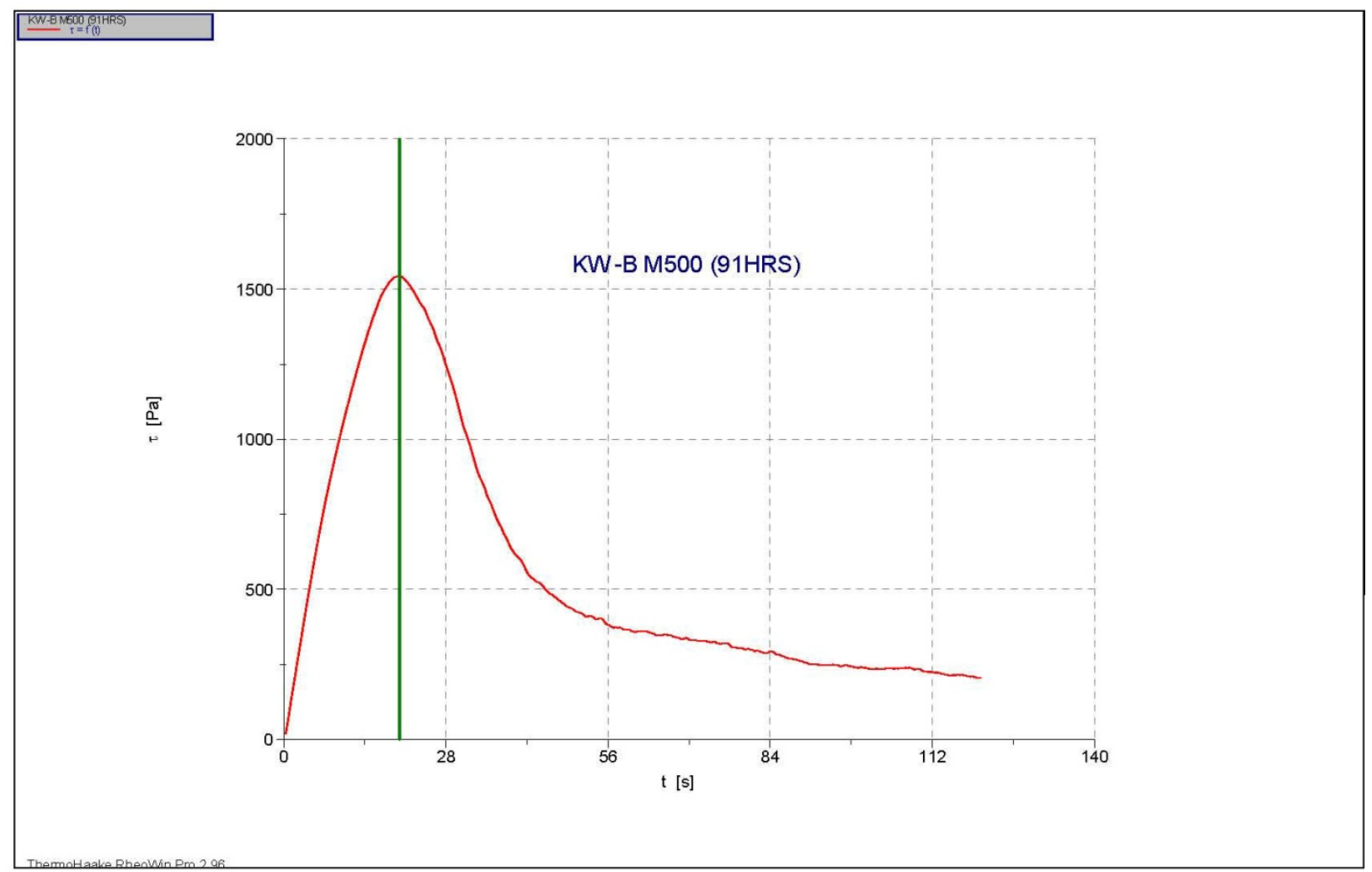

1: C:IRheologv Results $\backslash K$-Basin $\mid S h e a r$ Strength (vane) $\mid K W$-B M500 (91 HRS).rwd Company / Operator: PNNL / MARIA LUNA

Date / Time / Version: 16.03.2009 / 8:58:04 AM / RheoWin Pro 296

Substance / Sample no: KW-B M500 (91 HRS) / KW-B M500 (91HRS)

Curve discussion: Greatest value $\mathrm{t}[\mathrm{s}] 19.99 \tau[\mathrm{Pa}] 1543$. 
ThermoHaake RheoWin 3/16/2009 / 9:07 AM

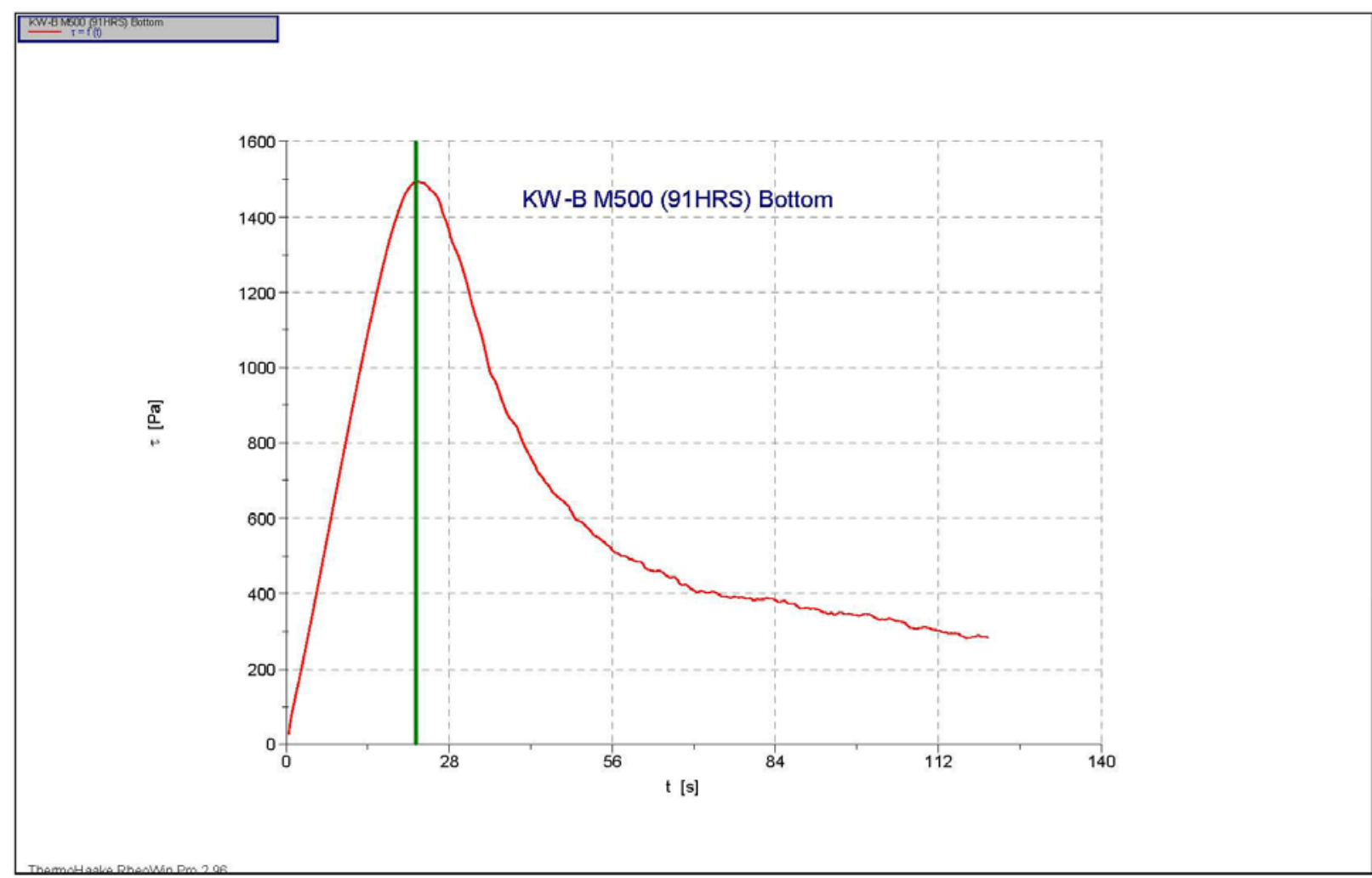

1: C:IRheologv Results\K-Basin IShear Strength (vane)\KW-B M500 (91HRS) Bottom.rwd Company / Operator: PNNL / MARIA LUNA

Date / Time / Version: 16.03.2009 / 9:02:05 AM / RheoWin Pro 296

Substance / Sample no: KW-B M500 (91HRS) Bottom / KW-B M500 (91HRS) Bottom Curve discussion: Greatest value $\mathrm{t}[\mathrm{s}] 22.28 \tau[\mathrm{Pa}] 1495$. 
ThermoHaake RheoWin 3/4/2009/1:16 PM

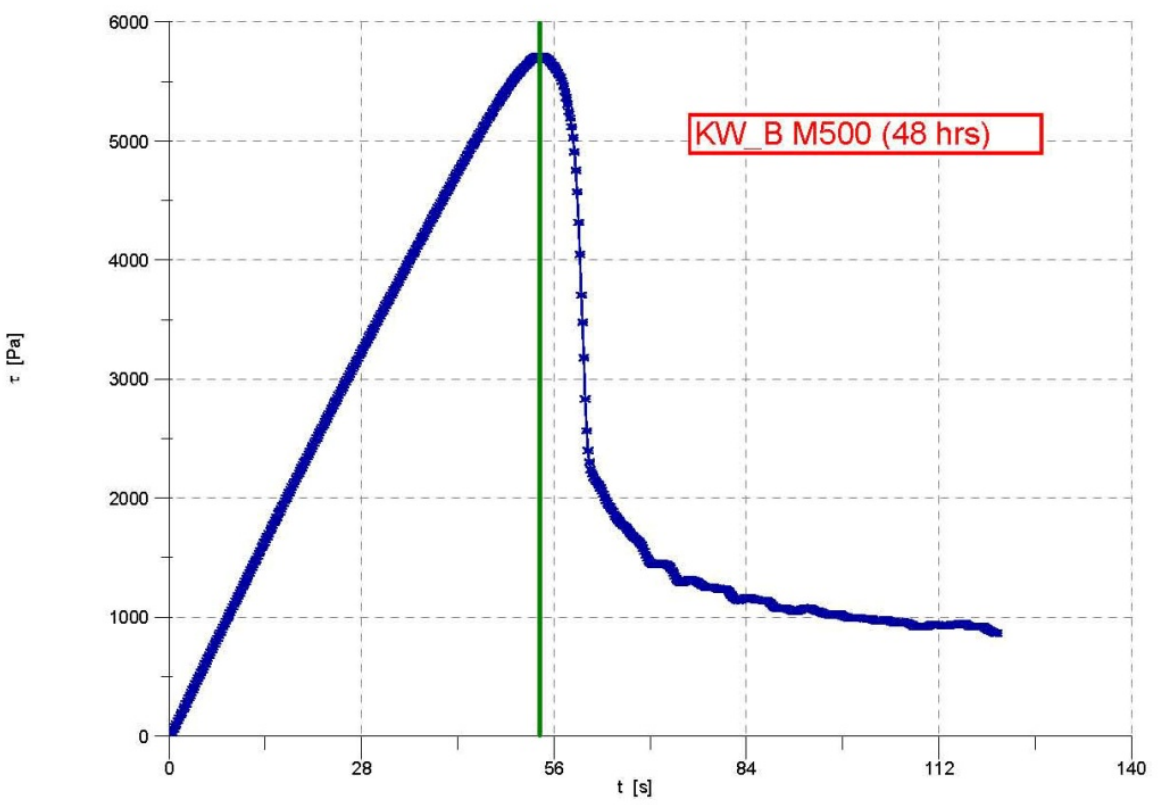

ThermoHaake RheoWin Pro 2.96

1: C:IRheologv Results 153019 -M12IShear Strength 1.6 X $1.6 \mathrm{~cm}$ VanelKW-B M500 21hr-2.rwd Company / Operator: PNNL / MARIA LUNA

Date / Time / Version: 04.03.2009 / 13:11:58 PM / RheoWin Pro 296

Substance / Sample no: KW-B M500 $21 \mathrm{hr}-2$ / KW-B M500 $21 \mathrm{hr}-2$

Curve discussion: Greatest value t [s] $53.96 \tau[\mathrm{Pa}] 5715$.

C.14 

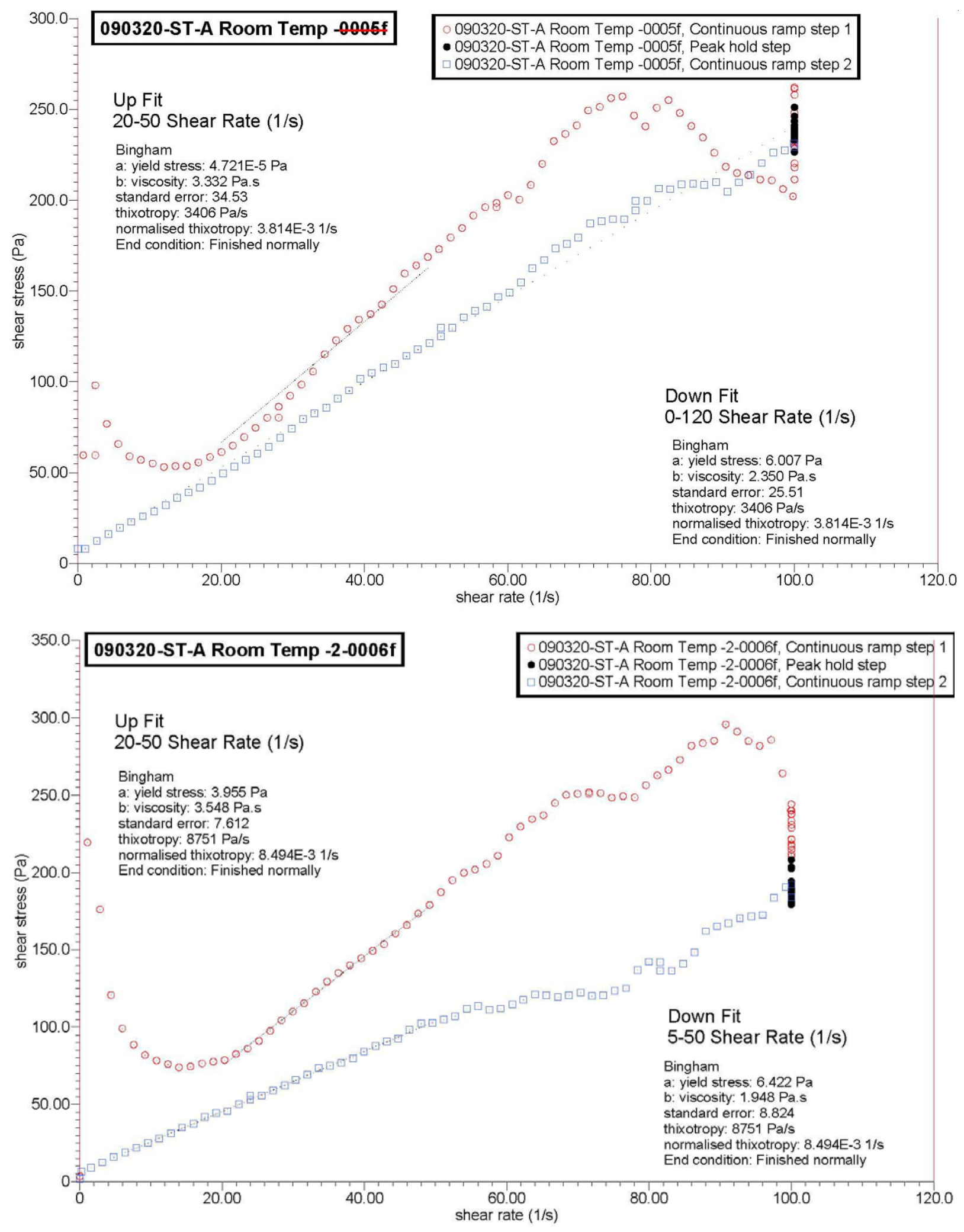

C. 15 


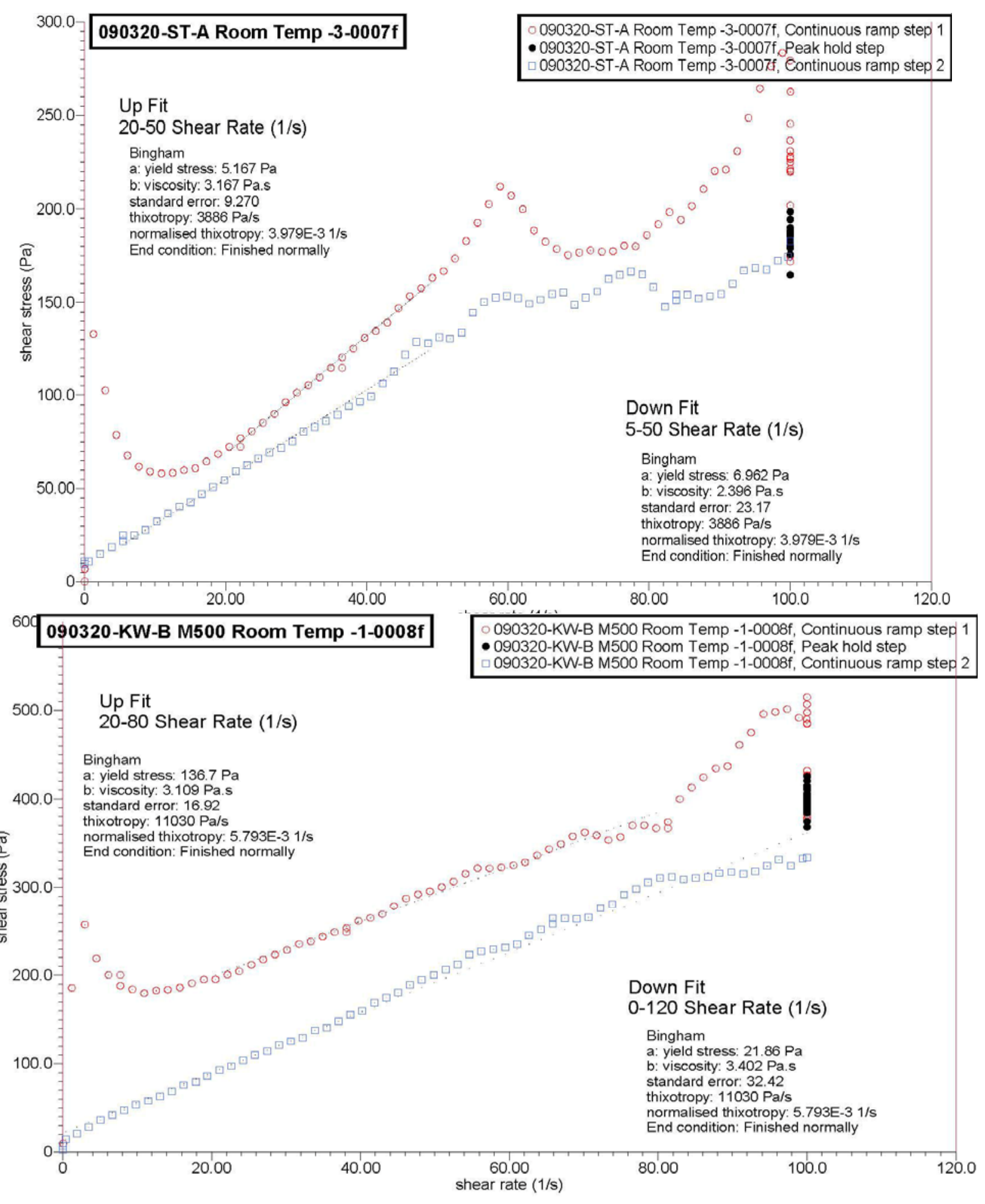

C. 16 

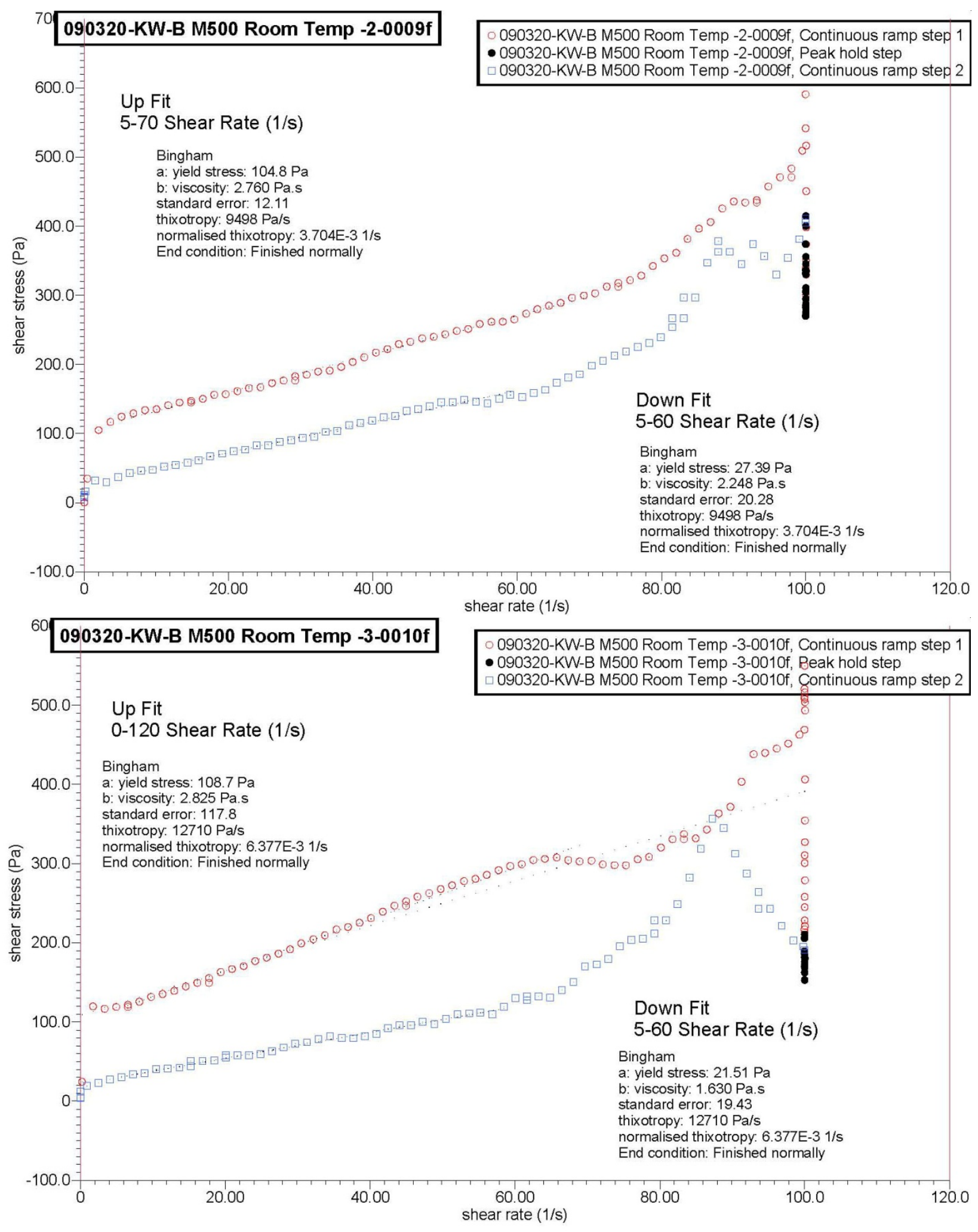

C. 17 

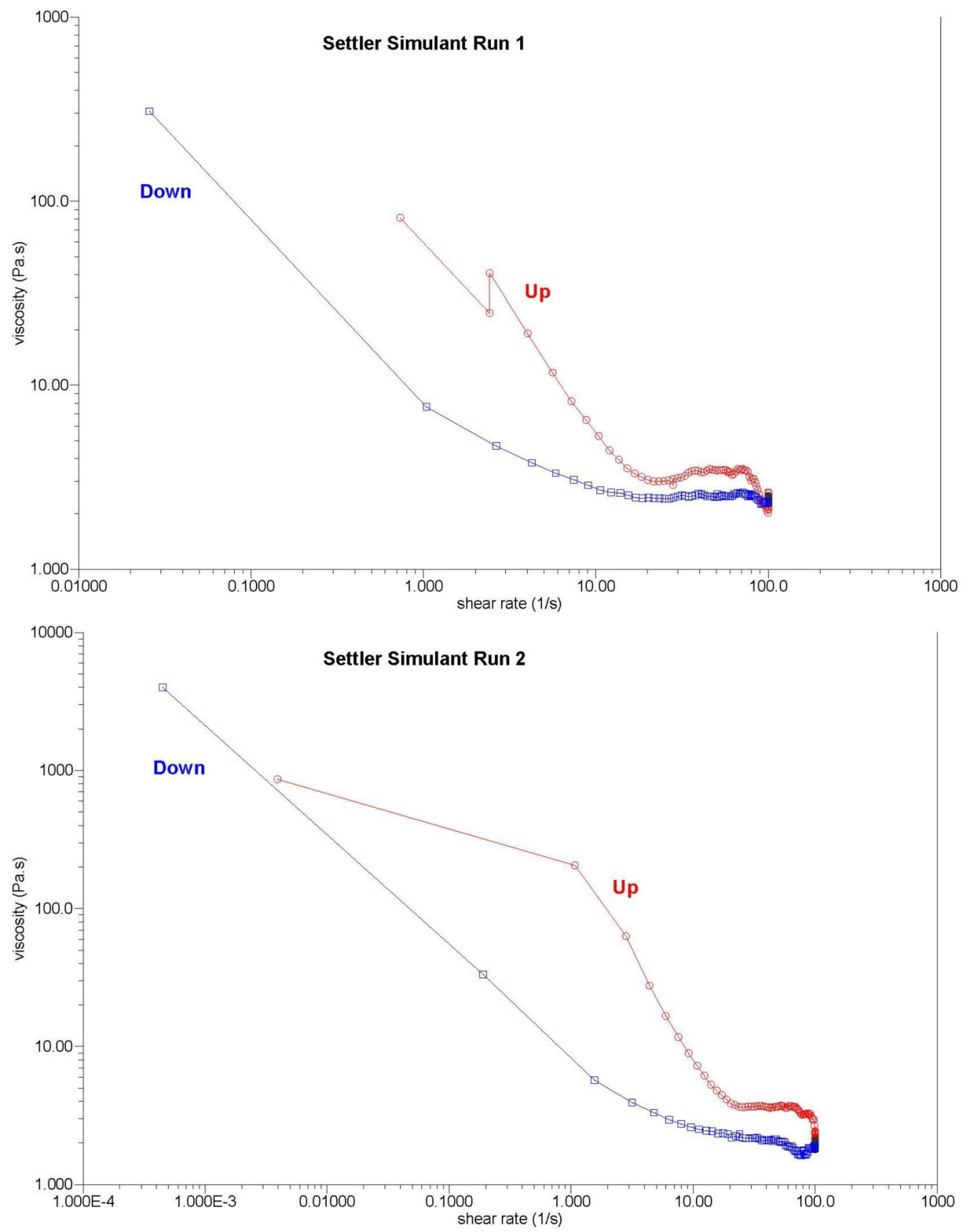

C. 18 

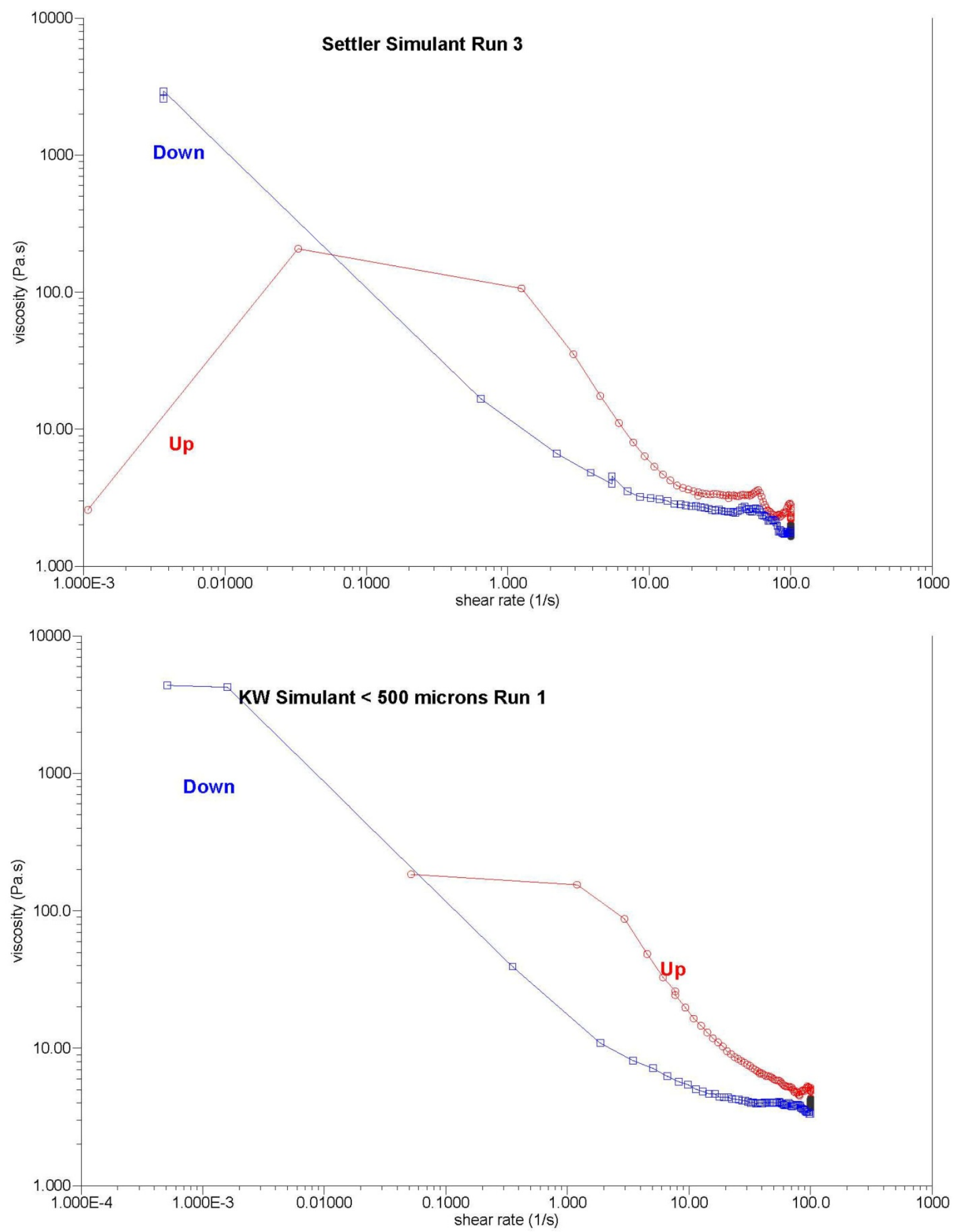

C.19 

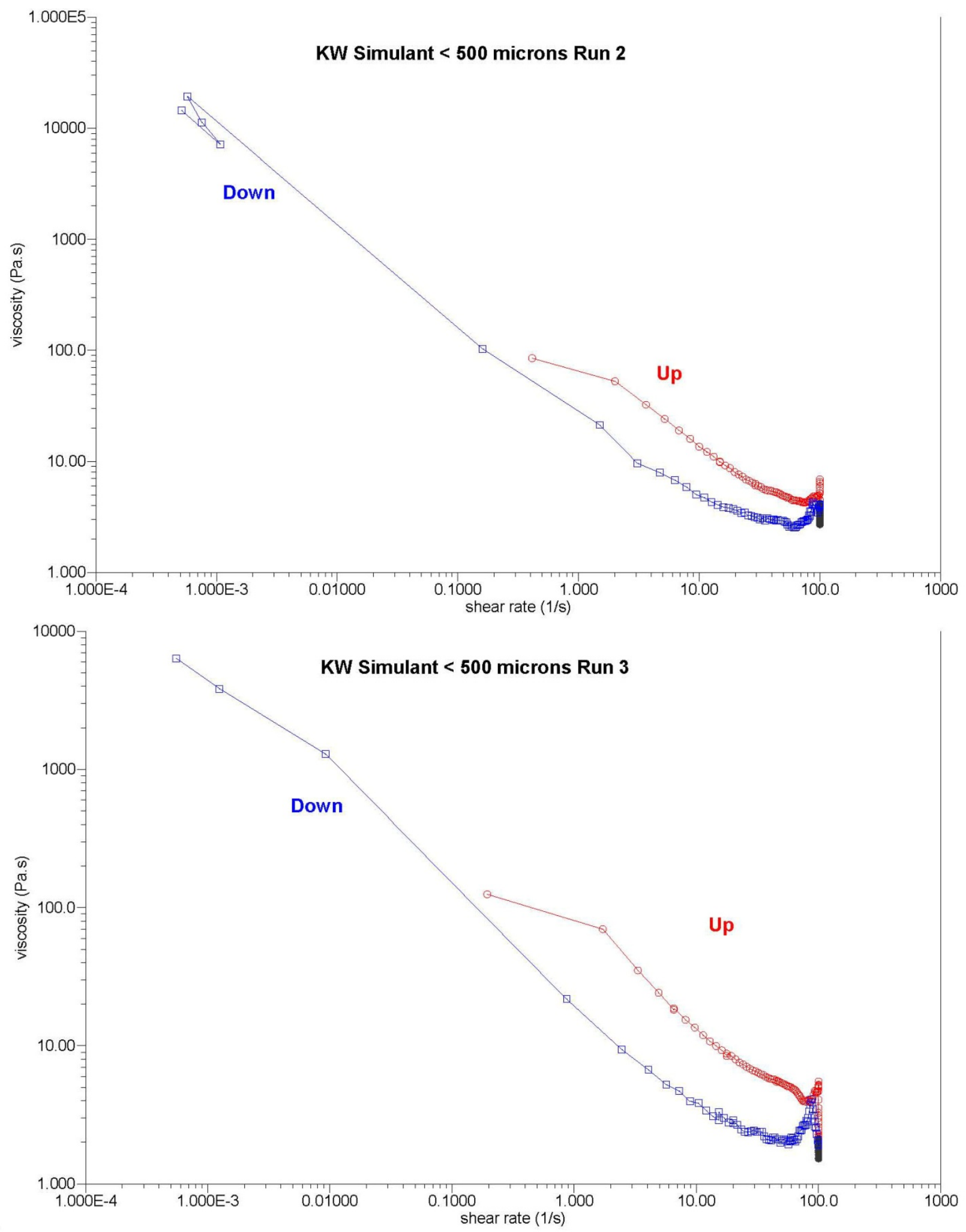
ThermoHaake RheoWin 2/11/2011/3:21 PM

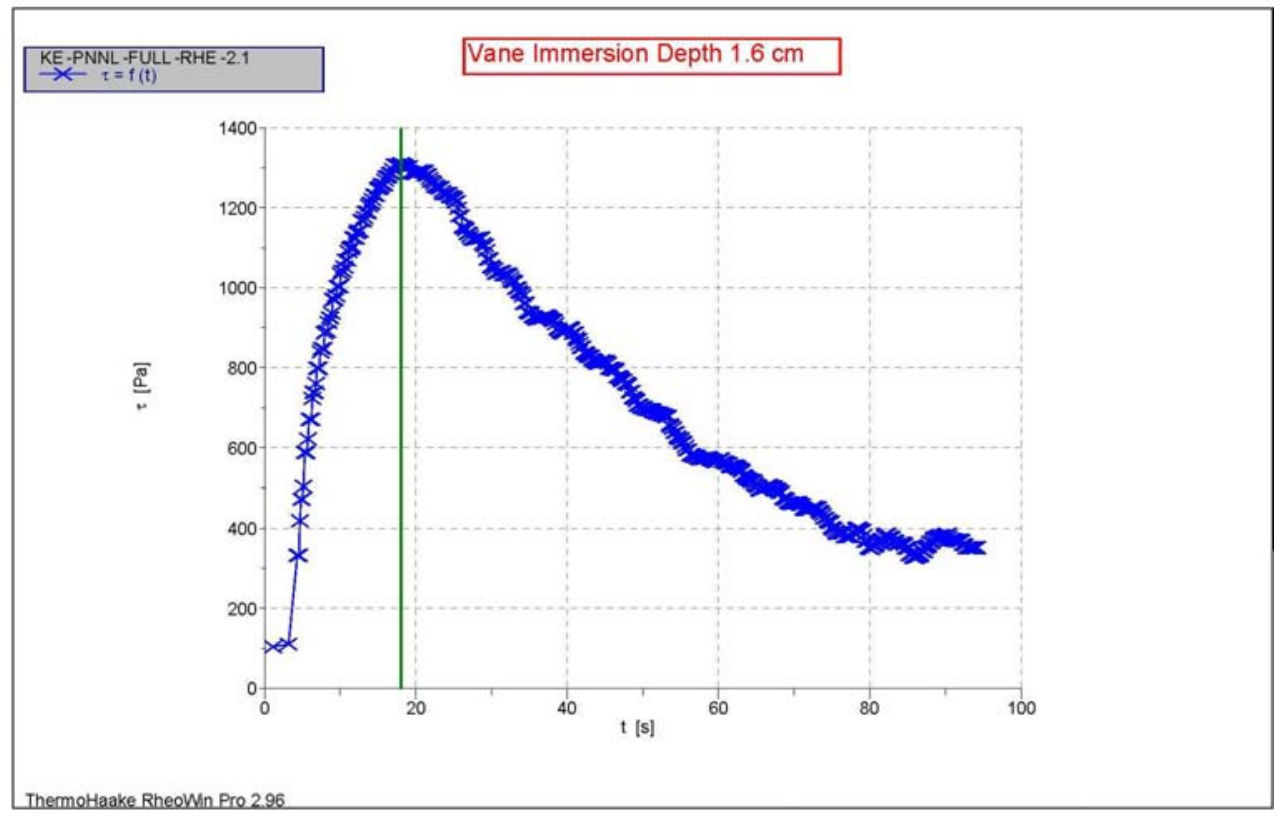

1: C: IProgram Files\RheoWin \Data $T$ TI37 shear strength Mix 1\KE -PNNL -FULL -RHE -2.1.rwd Company / Operator: PNNL / Carolyn Burns

Date / Time / Version: 10.02.2011 / 14:44:48 PM / RheoWin Pro 296

Substance / Sample no: KBasin TI037 / KE -PNNL -FULL -RHE -2.1

Curve discussion: Greatest value $\mathrm{t}[\mathrm{s}] 18.06 \tau[\mathrm{Pa}] 1310$.

ThermoHaake RheoWin 2/11/2011/3:24 PM

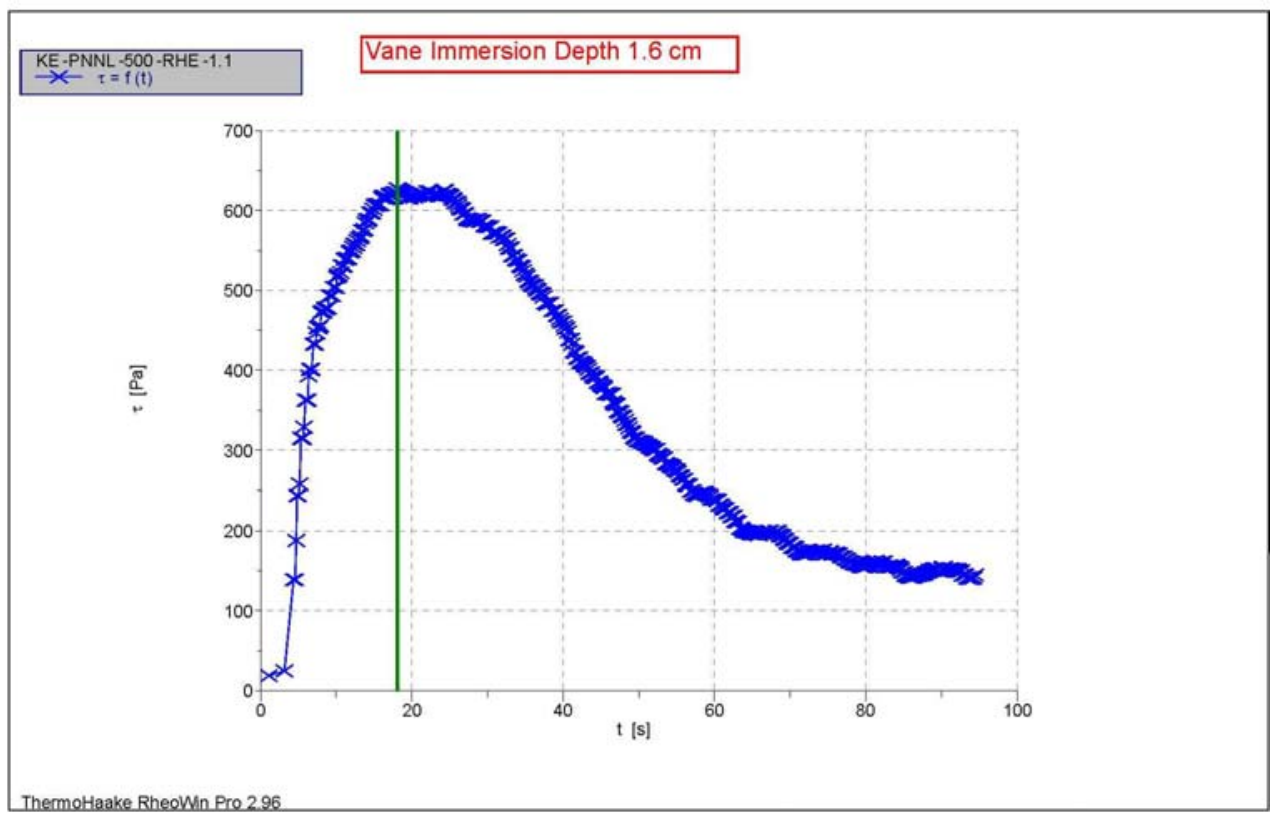

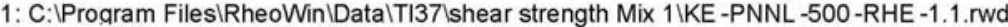
Company / Operator: PNNL / Carolyn Burns

Date / Time / Version: 10.02 2011/14:54:31 PM / RheoWin Pro 296

Substance / Sample no: KBasin TI037 / KE -PNNL -500-RHE -1.1

Curve discussion: Greatest value $\mathrm{t}[\mathrm{s}] 18.09 \tau[\mathrm{Pa}] 627.1$ 
ThermoHaake RheoWin 2/11/2011/3:25 PM

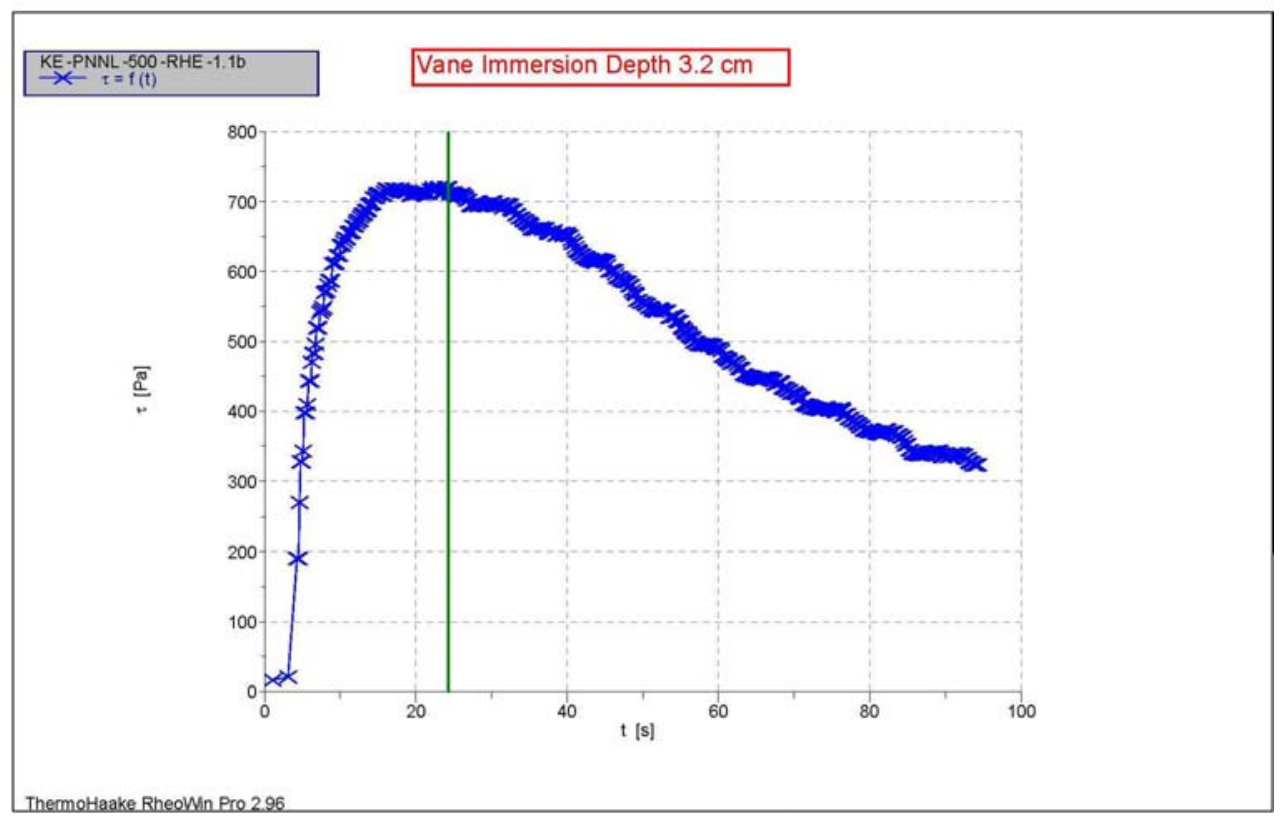

1: C:IProqram Files\RheoWin \Data|TI37/shear strength Mix 1\KE -PNNL -500-RHE -1.1b.rwd Company / Operator: PNNL / Carolyn Burns

Date / Time / Version: 10.02.2011 / 14:56:52 PM / RheoWin Pro 296

Substance / Sample no: KBasin TI037 / KE -PNNL -500-RHE -1.1b

Curve discussion: Greatest value $\mathrm{t}[\mathrm{s}] 24.33 \tau[\mathrm{Pa}] 719.2$

ThermoHaake RheoWin 2/11/2011/3:25 PM

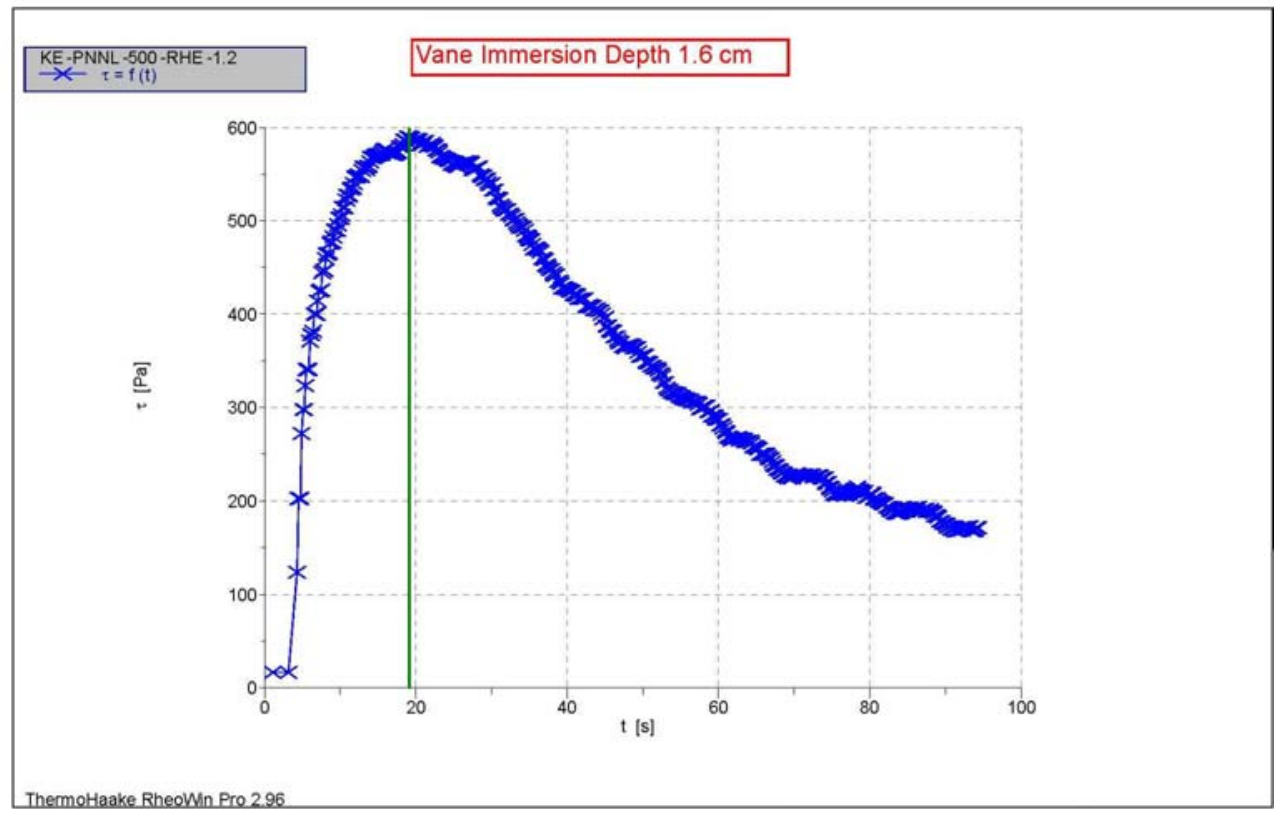

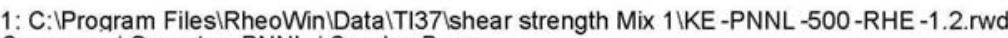
Company / Operator: PNNL / Carolyn Burns

Date / Time / Version: 10.02.2011 / 14:59:35 PM / RheoWin Pro 296

Substance / Sample no: KBasin TI037 / KE -PNNL -500-RHE -1.2

Curve discussion: Greatest value $\mathrm{t}[\mathrm{s}] 19.17 \tau[\mathrm{Pa}] 589.8$ 
ThermoHaake RheoWin 2/11/2011/3:32 PM

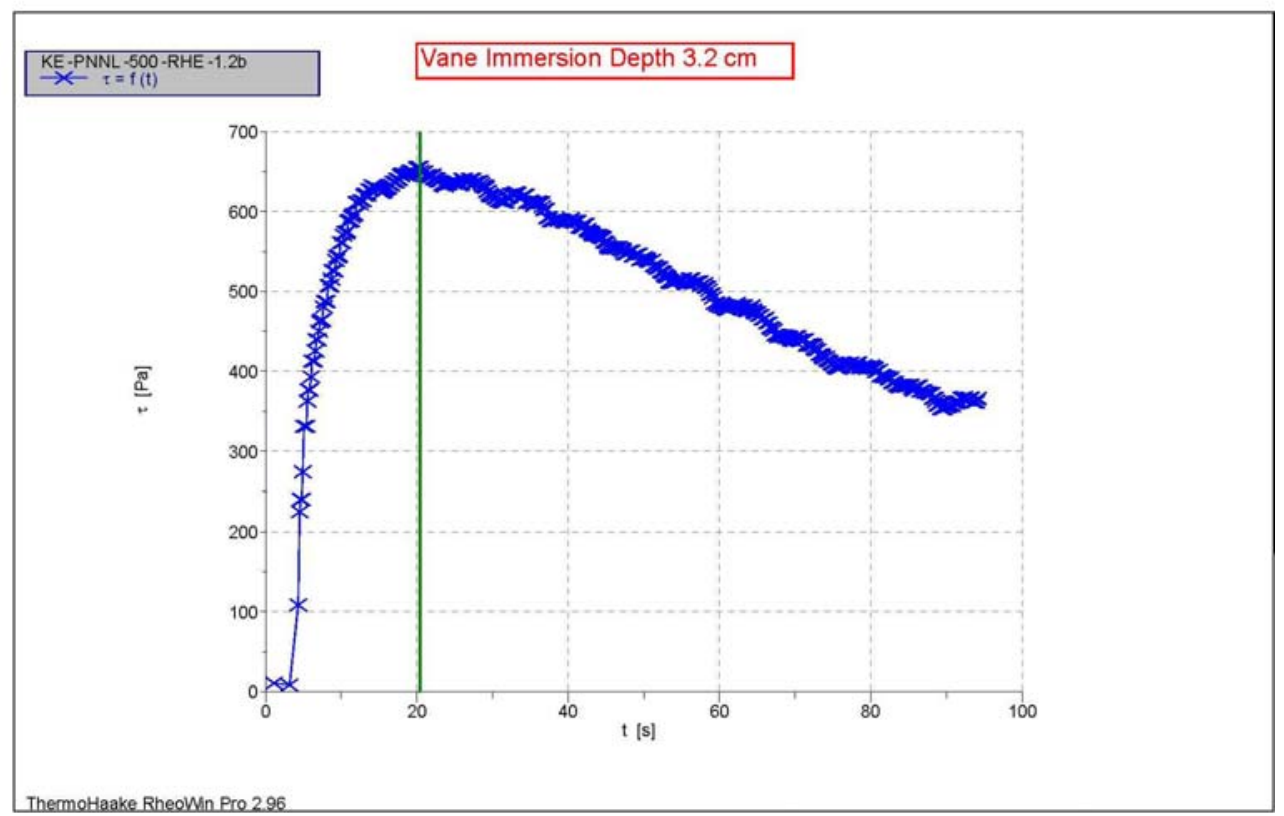

1: C:IProgram Files\RheoWin \DatalTI37/shear strength Mix 1\KE -PNNL -500-RHE -1.2b.rwd Company / Operator: PNNL / Carolyn Burns

Date / Time / Version: 10.02.2011 / 15:01:39 PM / RheoWin Pro 296

Substance / Sample no: KBasin TI037 / KE -PNNL -500-RHE -1.2b

Curve discussion: Greatest value $\mathrm{t}[\mathrm{s}] 20.41 \tau[\mathrm{Pa}] 655.1$

ThermoHaake RheoWin 2/11/2011/3:27 PM

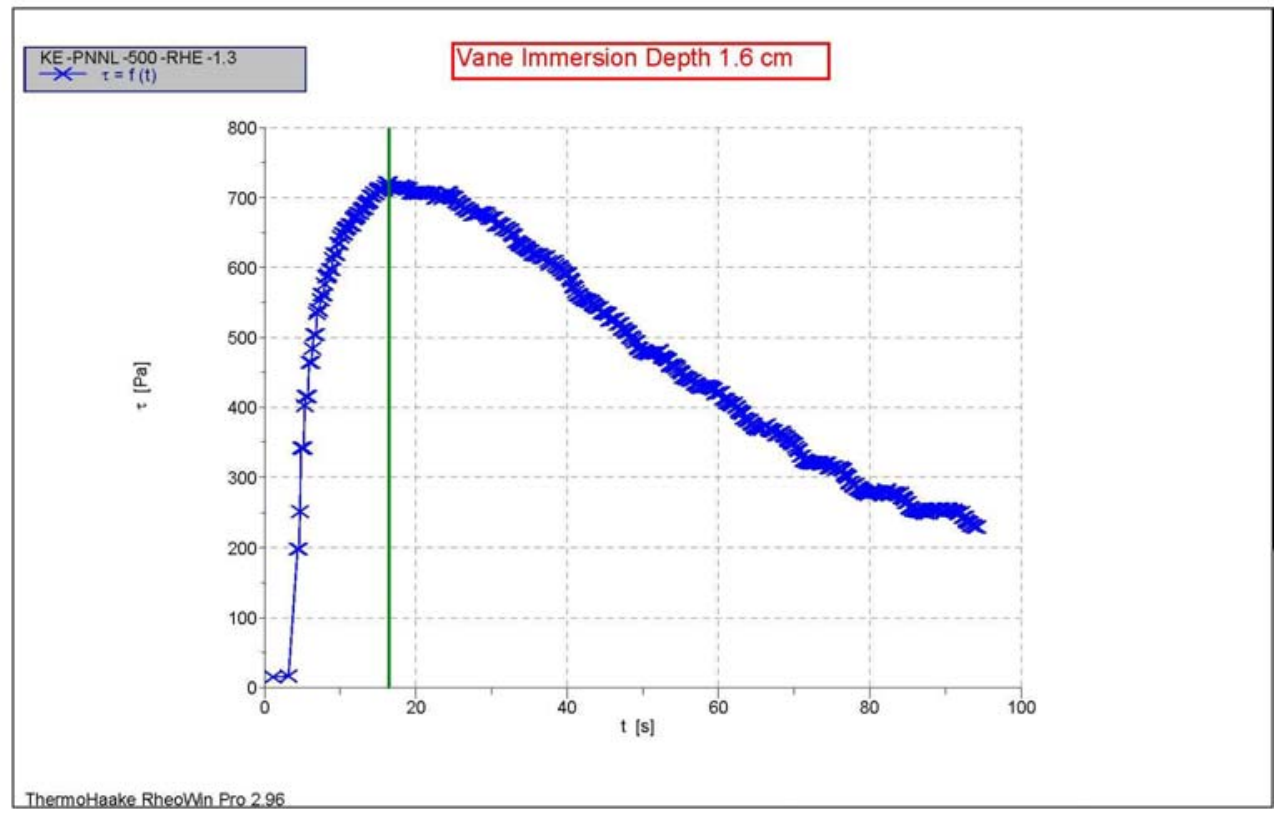

1: C:IProgram Files\RheoWin\DatalTI37/shear strength Mix 1\KE -PNNL -500-RHE -1.3.rwd Company / Operator: PNNL / Carolyn Burns

Date / Time / Version: 10.02.2011 / 15:04:31 PM / RheoWin Pro 296

Substance / Sample no: KBasin TI037 / KE -PNNL -500-RHE -1.3

Curve discussion: Greatest value $\mathrm{t}[\mathrm{s}] 16.44 \tau[\mathrm{Pa}] 720.4$ 
ThermoHaake RheoWin 2/11/2011/3:28 PM

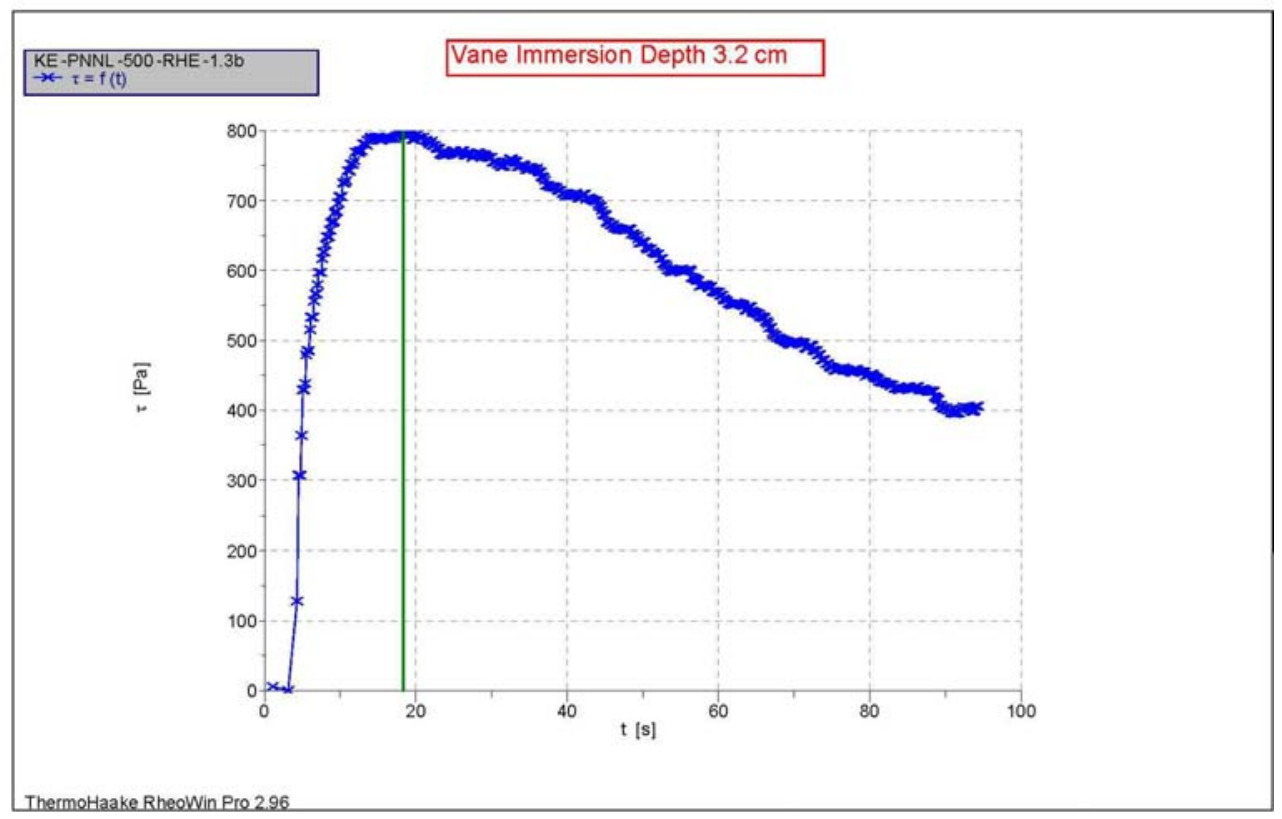

1: C:IProgram Files\RheoWin \DatalTI37/shear strength Mix 1\KE -PNNL -500-RHE -1.3b.rwd Company / Operator: PNNL / Carolyn Burns

Date / Time / Version: 10.02.2011 / 15:06:35 PM / RheoWin Pro 296

Substance / Sample no: KBasin TI037 / KE -PNNL -500-RHE -1.3b

Curve discussion: Greatest value $\mathrm{t}[\mathrm{s}] 18.33 \tau[\mathrm{Pa}] 797.3$

ThermoHaake RheoWin 2/11/2011/3:30 PM

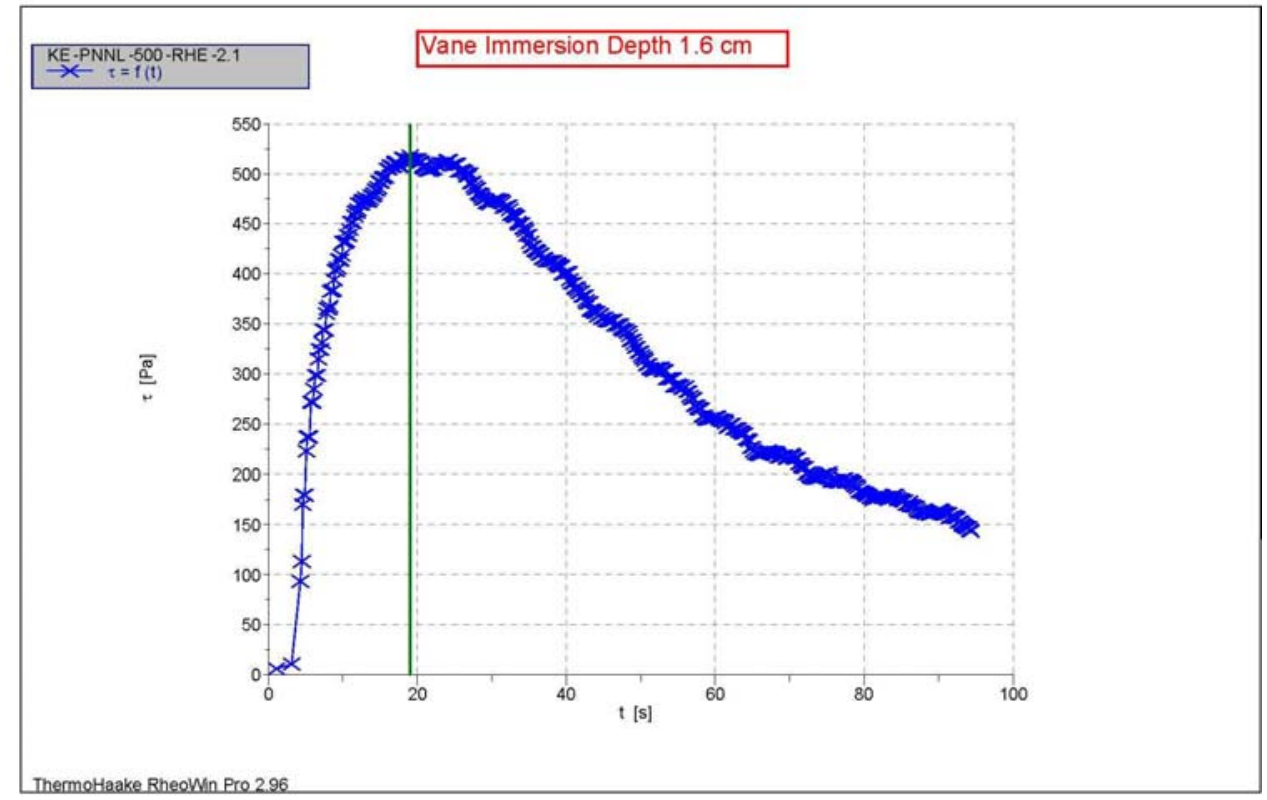

1: C: $\mid$ Program Files $\backslash R$ heoWin $\backslash D a t a \backslash T I 37$ shear strength Mix 1\KE -PNNL -500-RHE -2.1.rwd Company / Operator: PNNL / Carolyn Burns

Date / Time / Version: 10.02.2011 / 15:10:43 PM / RheoWin Pro 296

Substance / Sample no: KBasin TI037 / KE -PNNL -500-RHE -2.1

Curve discussion: Greatest value $\mathrm{t}[\mathrm{s}] 19.05 \tau[\mathrm{Pa}] 517.6$ 
ThermoHaake RheoWin 2/11/2011/3:31 PM

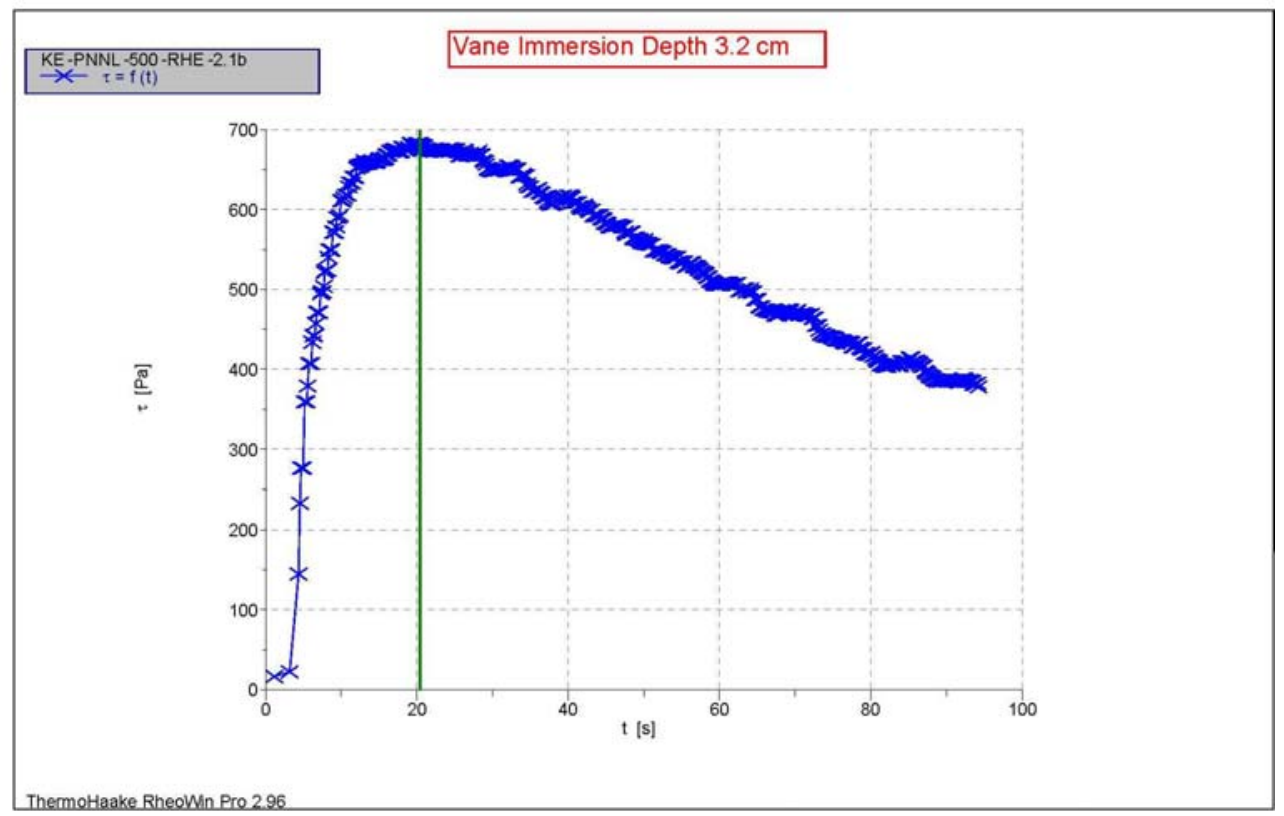

1: C:IProqram Files\RheoWin \Data|TI37/shear strength Mix 1\KE -PNNL -500-RHE -2.1b.rwd Company / Operator: PNNL / Carolyn Burns

Date / Time / Version: 10.02.2011 / 15:12:56 PM / RheoWin Pro 296

Substance / Sample no: KBasin TI037 / KE -PNNL -500-RHE -2.1b

Curve discussion: Greatest value $\mathrm{t}[\mathrm{s}] 20.44 \tau[\mathrm{Pa}] 681.9$

ThermoHaake RheoWin 2/11/2011/3:15 PM

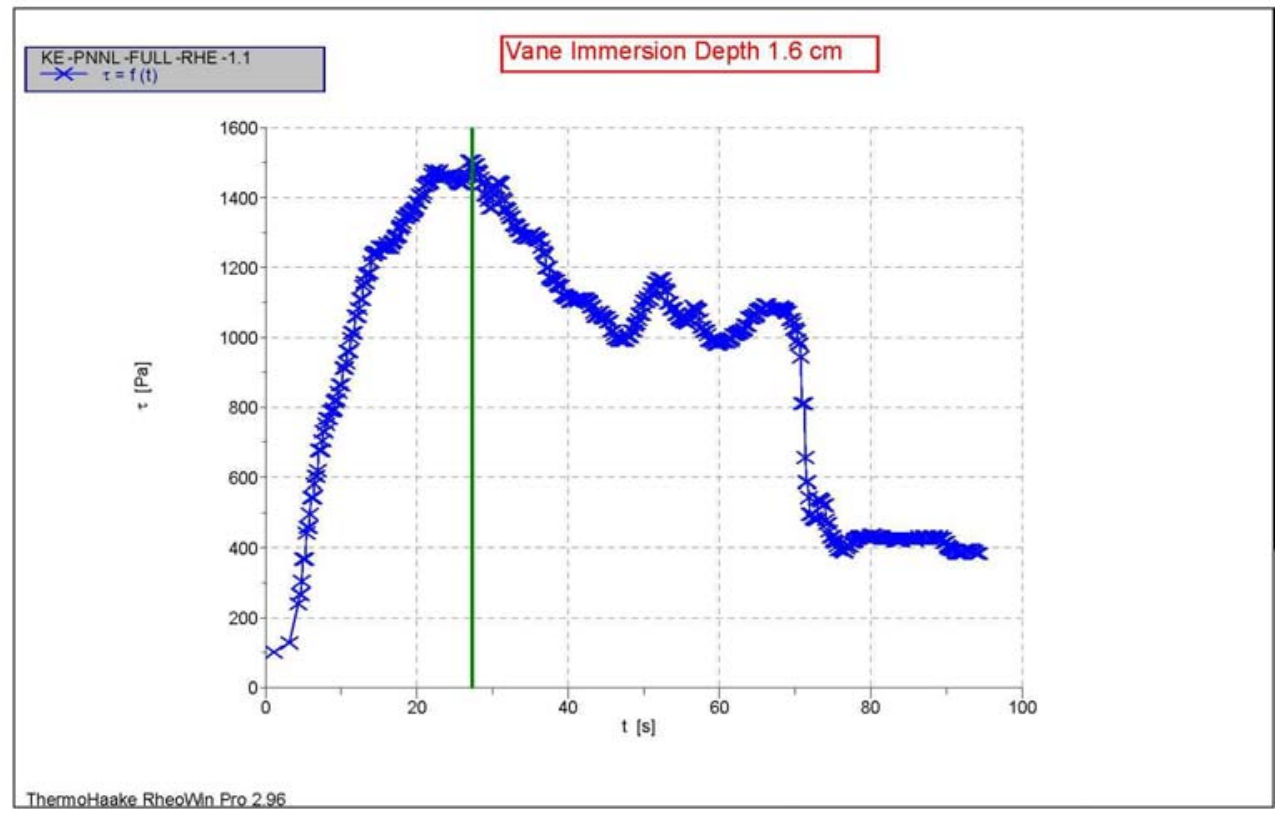

1: C:IProgram FilesIRheoWin IDatalTI37/shear strength Mix 1IKE -PNNL -FULL -RHE -1.1.rwd Company / Operator: PNNL / Carolyn Burns

Date / Time / Version: 10.02.2011 / 14:18:40 PM / RheoWin Pro 296

Substance / Sample no: KBasin T137 / KE -PNNL -FULL -RHE -1.1

Curve discussion: Greatest value $\mathrm{t}[\mathrm{s}] 27.33 \tau[\mathrm{Pa}] 1503$. 


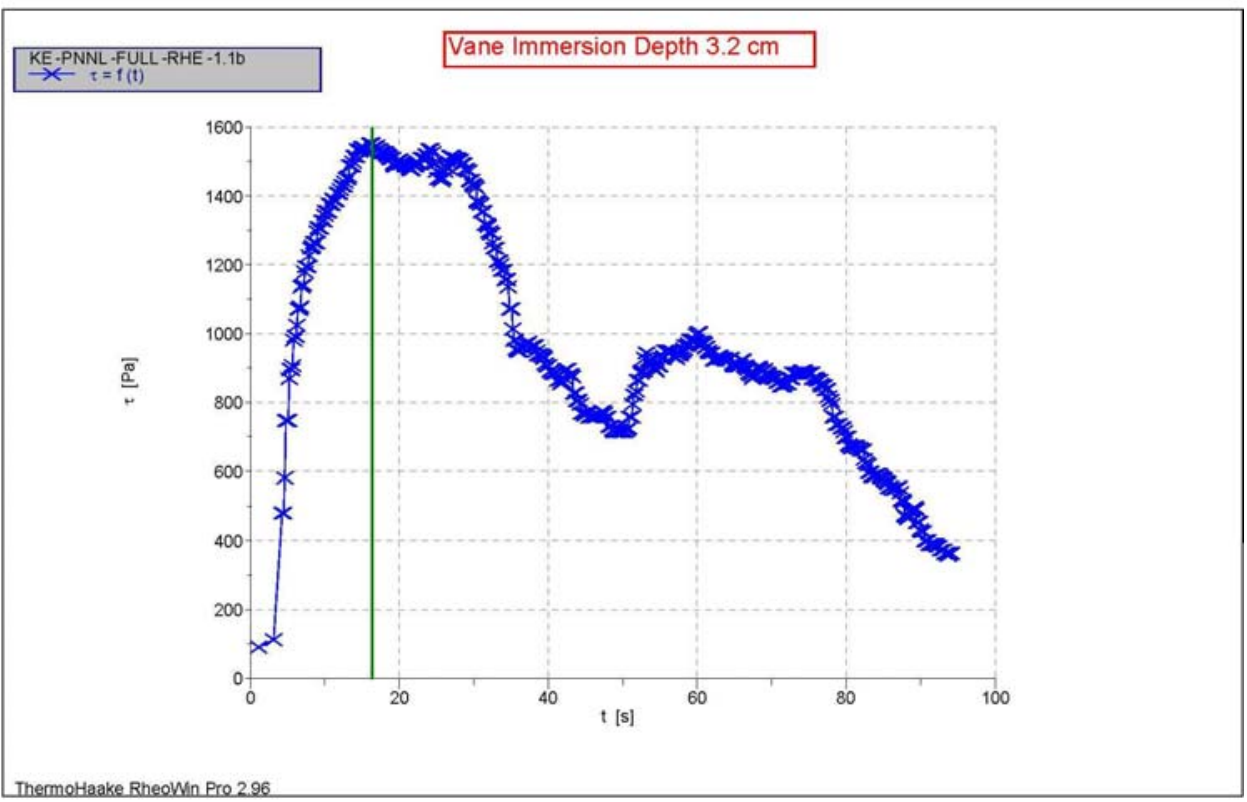

1: C:IProgram Files\RheoWin IDatalTI37/shear strength Mix 1VKE -PNNL -FULL -RHE -1.1b.rwd Company / Operator: PNNL / Carolyn Burns

Date / Time / Version: 10.02.2011 / 14:21:21 PM / RheoWin Pro 296

Substance / Sample no: KBasin TI37 / KE -PNNL -FULL -RHE -1.1b

Curve discussion: Greatest value $\mathrm{t}[\mathrm{s}] 16.34 \tau[\mathrm{Pa}] 1551$.

ThermoHaake RheoWin 2/11/2011/3:19 PM

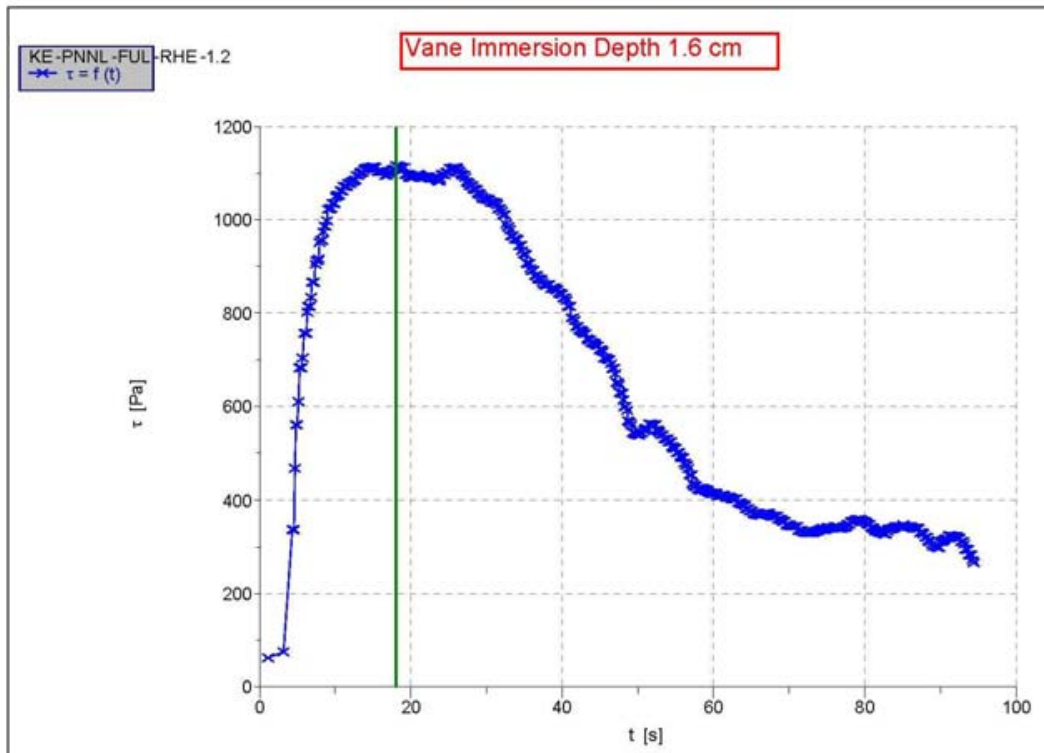

ThermoHaake RheolWin Pro 2.96

1: C:IProgram Files\RheoWin \DatalTI37/shear strength Mix 1\KE -PNNL - FUL -RHE -1.2.rwd Company / Operator: PNNL / Carolyn Burns

Date / Time / Version: 10.02.2011 / 14:28:10 PM / RheoWin Pro 296

Substance / Sample no: KBasin TI037 / KE -PNNL -FUL -RHE -1.2

Curve discussion: Greatest value $\mathrm{t}[\mathrm{s}] 18.06 \tau[\mathrm{Pa}] 1116$. 


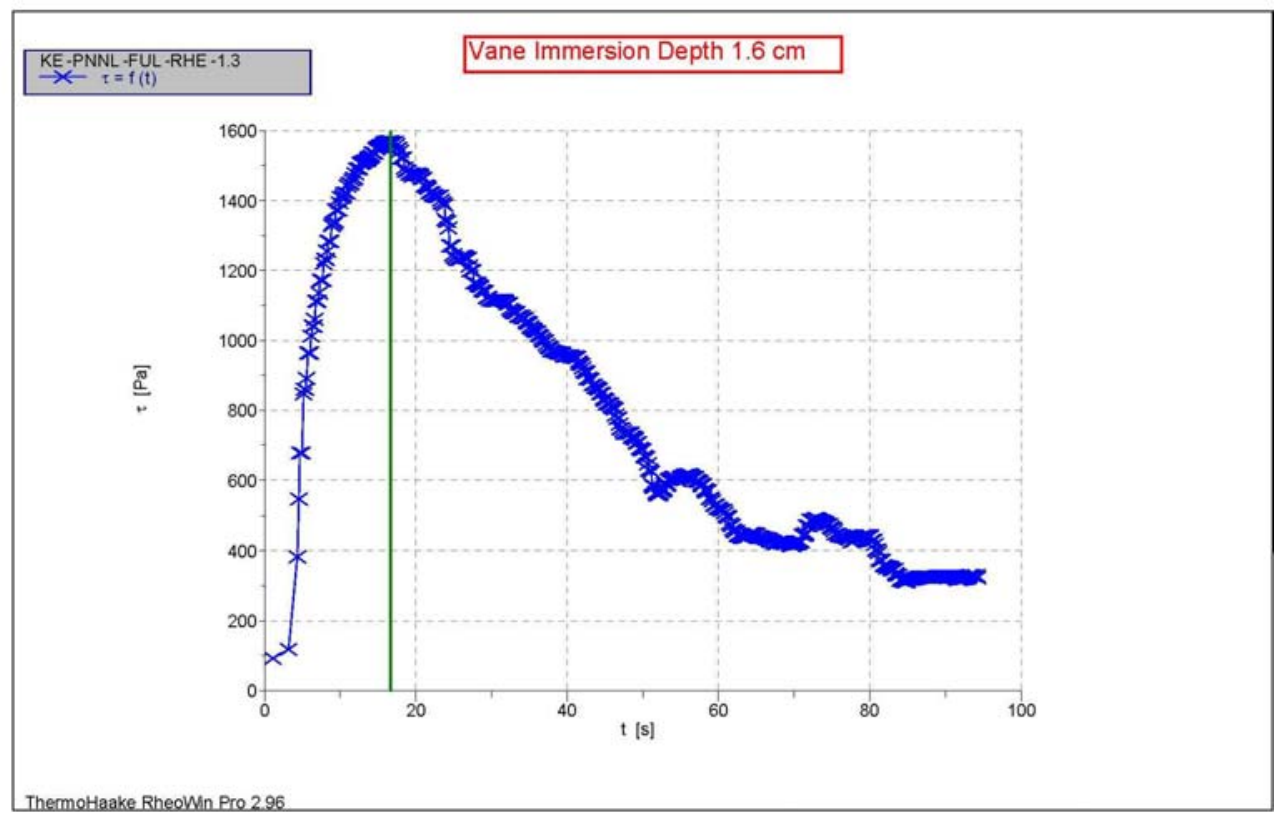

1: C:IProgram Files $\backslash R$ heoWin $\backslash D$ ata $|T| 37 /$ shear strength Mix 1 IKE -PNNL -FUL -RHE -1.3.rwd Company / Operator: PNNL / Carolyn Burns

Date / Time / Version: 10.02.2011 / 14:31:02 PM / RheoWin Pro 296

Substance / Sample no: KBasin TI037 / KE -PNNL-FUL-RHE -1.3

Curve discussion: Greatest value $\mathrm{t}[\mathrm{s}] 16.67 \tau[\mathrm{Pa}] 1568$.

ThermoHaake RheoWin 2/11/2011/3:43 PM

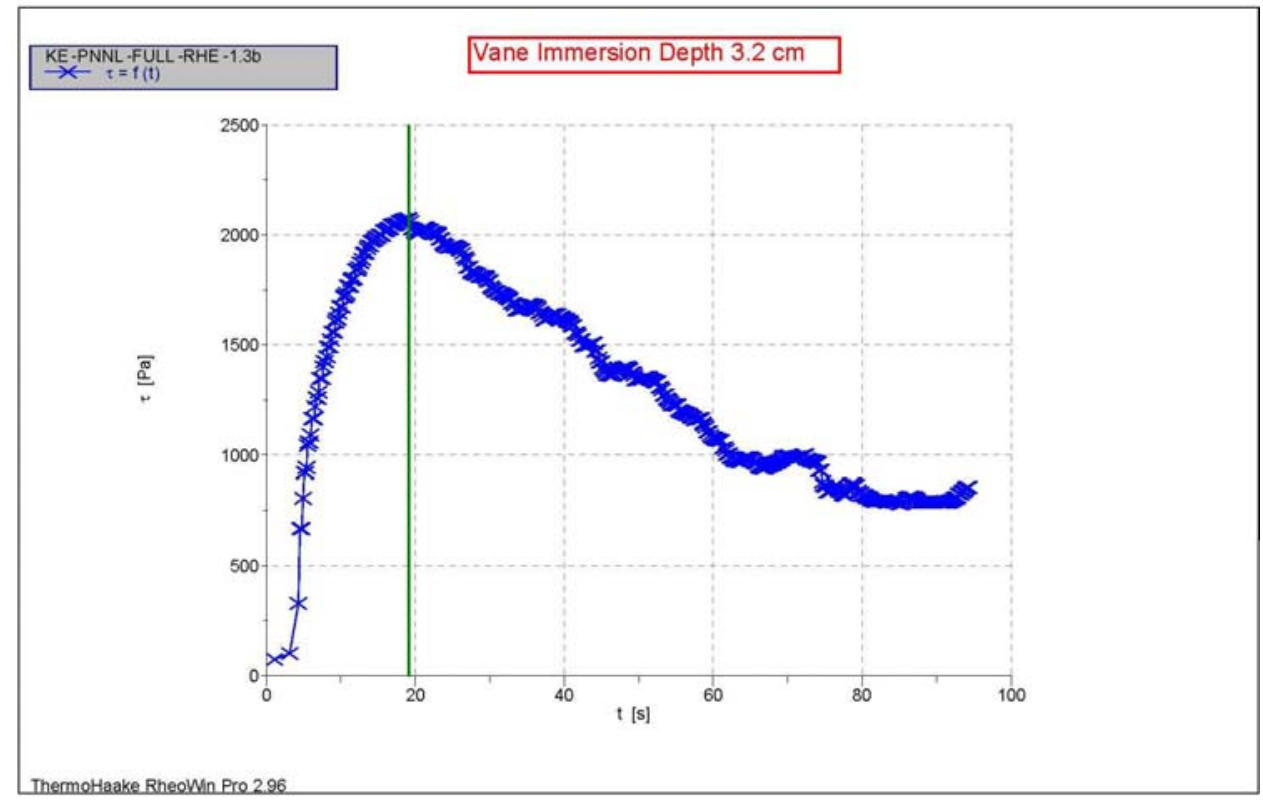

1: C: $\mid$ Program Files\RheoWin $\backslash$ DatalTI37/shear strength Mix 1 $\mathrm{KEE}$-PNNL -FULL -RHE -1.3b.rwd Company / Operator: PNNL / Carolyn Burns

Date / Time / Version: 10.02.2011 / 14:35:03 PM / RheoWin Pro 296

Substance / Sample no: KBasin TI037 / KE -PNNL -FULL -RHE -1.3b

Curve discussion: Greatest value t [s] $19.17 \tau[\mathrm{Pa}] 2071$. 
ThermoHaake RheoWin 2/11/2011/3:22 PM

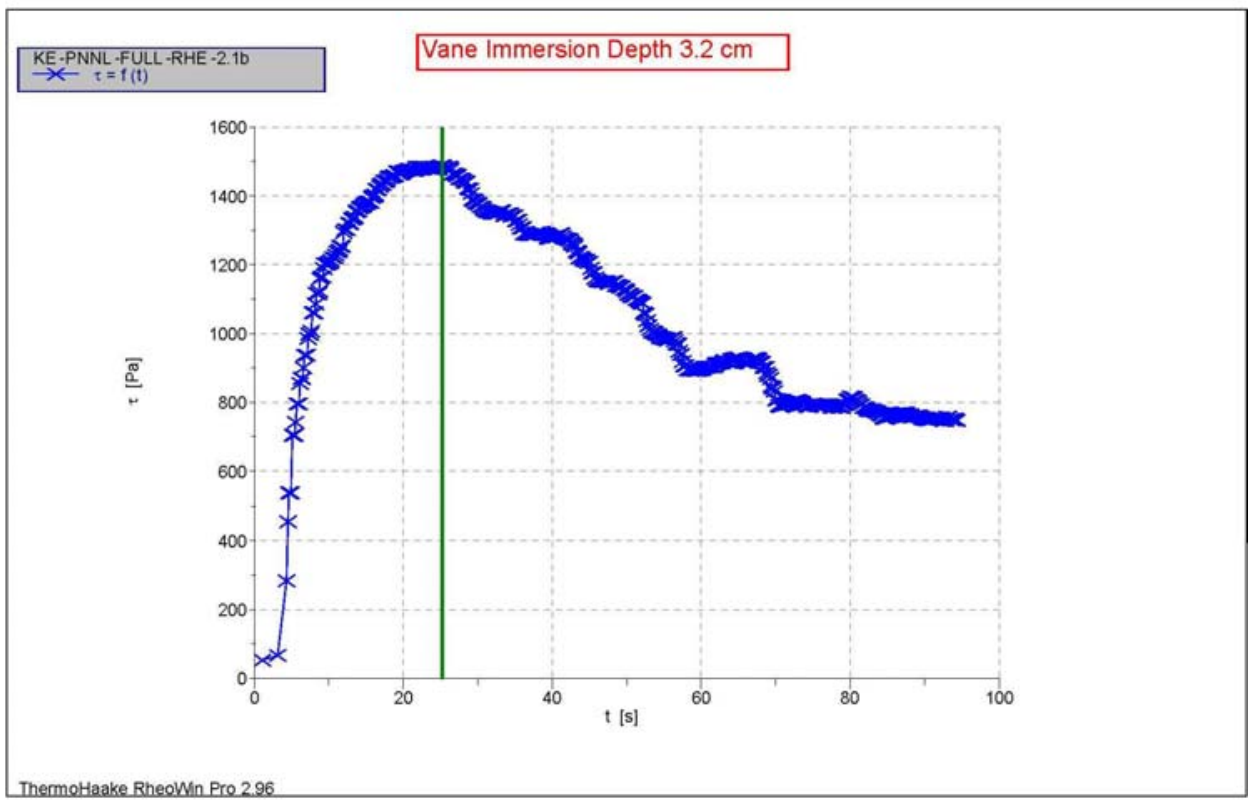

1: C:IProgram Files\RheoWin \DatalTI37/shear strength Mix 1\KE -PNNL -FULL -RHE -2.1b.rwd Company / Operator: PNNL / Carolyn Burns

Date / Time / Version: 10.02.2011 / 14:47:06 PM / RheoWin Pro 296

Substance / Sample no: KBasin TI037 / KE -PNNL - FULL -RHE -2.1b

Curve discussion: Greatest value $\mathrm{t}[\mathrm{s}] 25.23 \tau[\mathrm{Pa}] 1486$. 
ThermoHaake RheoWin 2/14/2011/3:02 PM

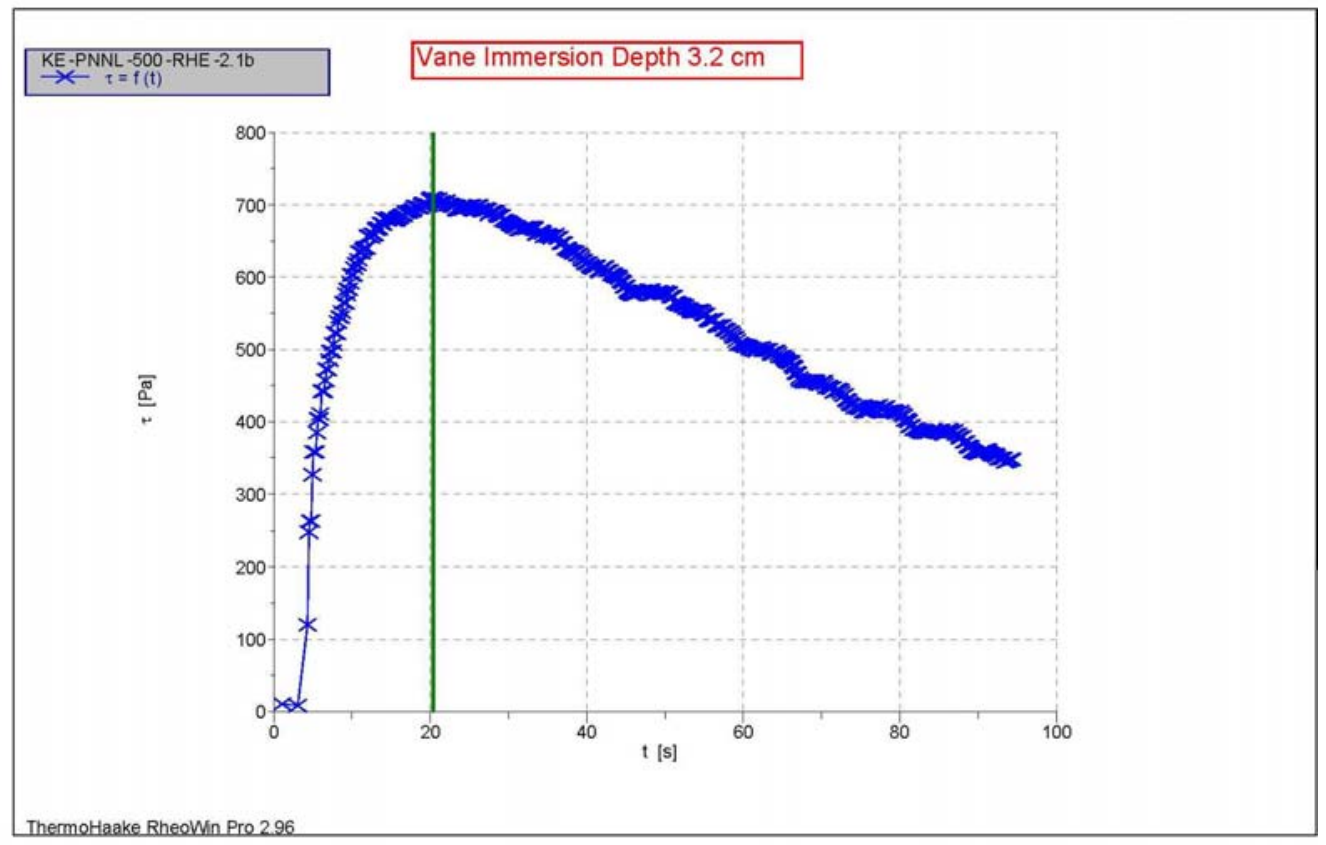

1: C:IProgram Files IRheoWin IDatalTI37/Shear strength Mix 2VKE -PNNL-500-RHE -2.1b.rwd Company / Operator: PNNL / Carolyn Burns

Date / Time / Version: 12.02.2011 / 18:36:29 PM / RheoWin Pro 296

Substance / Sample no: KBasin TI037 / KE -PNNL-500 -RHE -2.1b

Curve discussion: Greatest value $\mathrm{t}[\mathrm{s}] 20.39 \tau[\mathrm{Pa}] 708.7$

ThermoHaake RheoWin 2/14/2011/3:12 PM

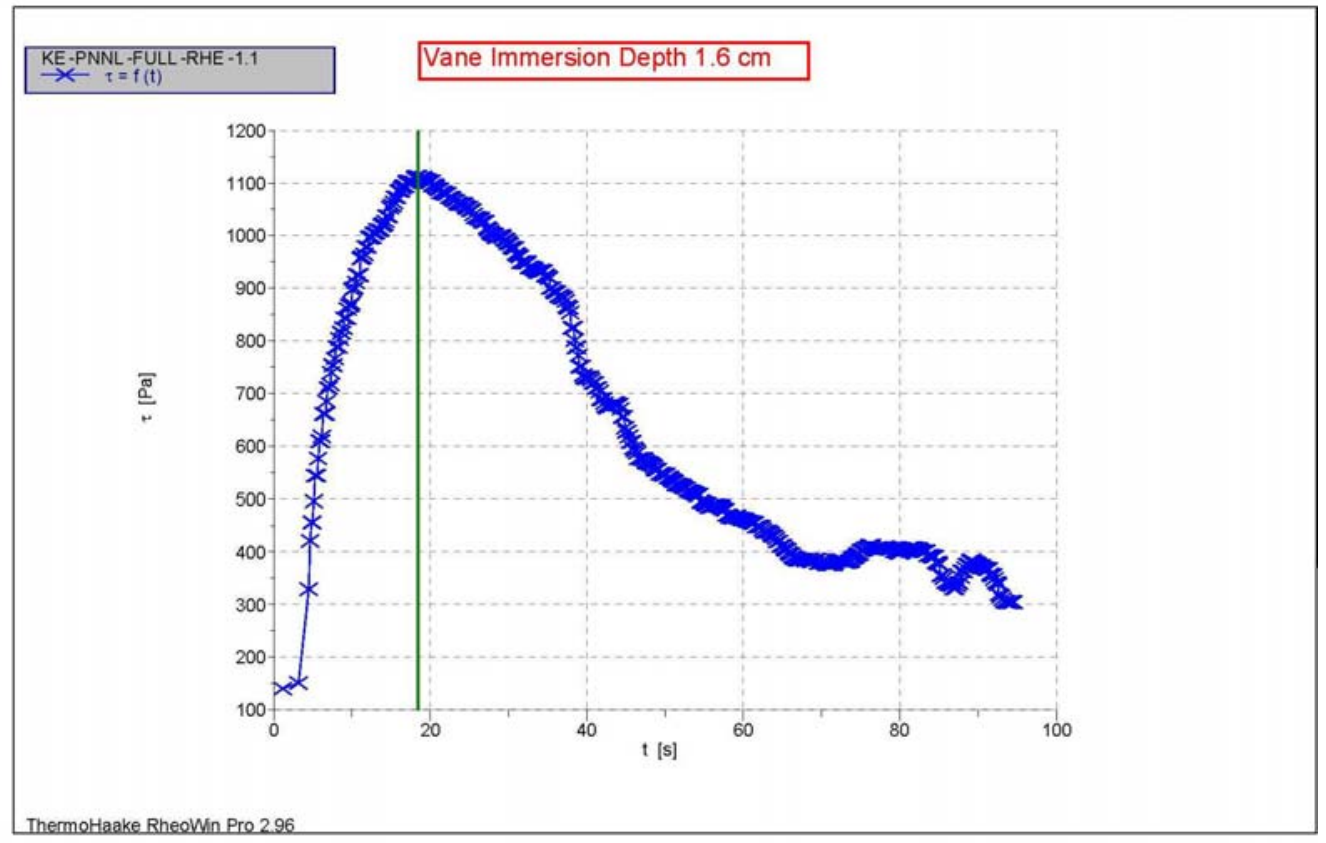

1: C:IProgram FilesIRheoWin IDatalTI37|Shear strength Mix 2IKE -PNNL-FULL -RHE -1.1.rwd Company / Operator: PNNL / Carolyn Burns

Date / Time / Version: 12.02.2011 / 17:40:15 PM / RheoWin Pro 296

Substance / Sample no: KBasin TI037 / KE -PNNL-FULL-RHE -1.1

Curve discussion: Greatest value $\mathrm{t}[\mathrm{s}] 18.48 \tau[\mathrm{Pa}] 1112$. 
ThermoHaake RheoWin 2/14/2011/3:14 PM

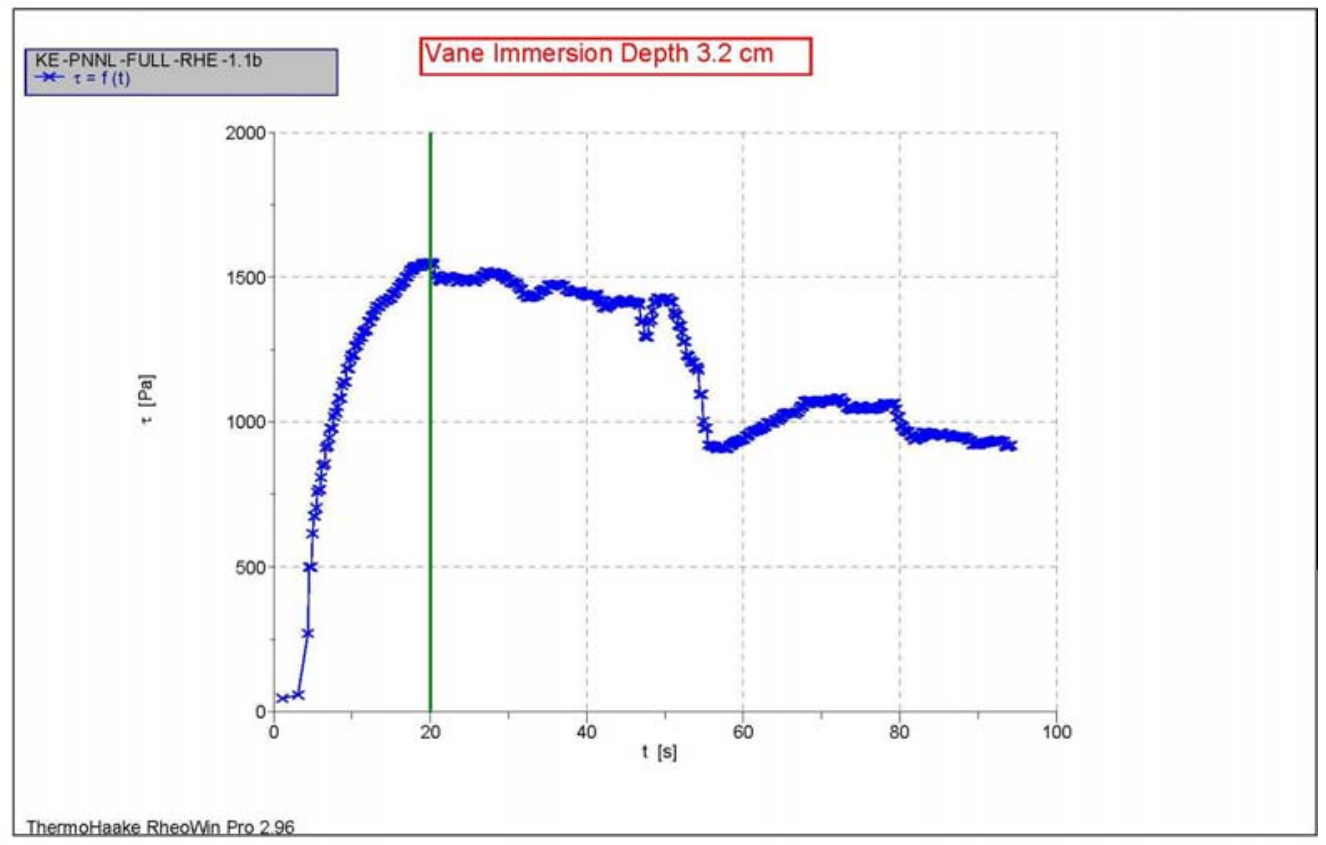

1: C:IProgram Files $\backslash R$ heoWin $\backslash$ Data $|T| 37 \backslash$ Shear strength Mix 2\KE -PNNL -FULL -RHE -1.1b.rwd Company / Operator: PNNL / Carolyn Burns

Date / Time / Version: 12.02.2011 / 17:43:04 PM / RheoWin Pro 296

Substance / Sample no: KBasin TI037 / KE -PNNL-FULL -RHE -1.1b

Curve discussion: Greatest value $\mathrm{t}[\mathrm{s}] 20.01 \tau[\mathrm{Pa}] 1550$.

ThermoHaake RheoWin 2/14/2011/3:14 PM

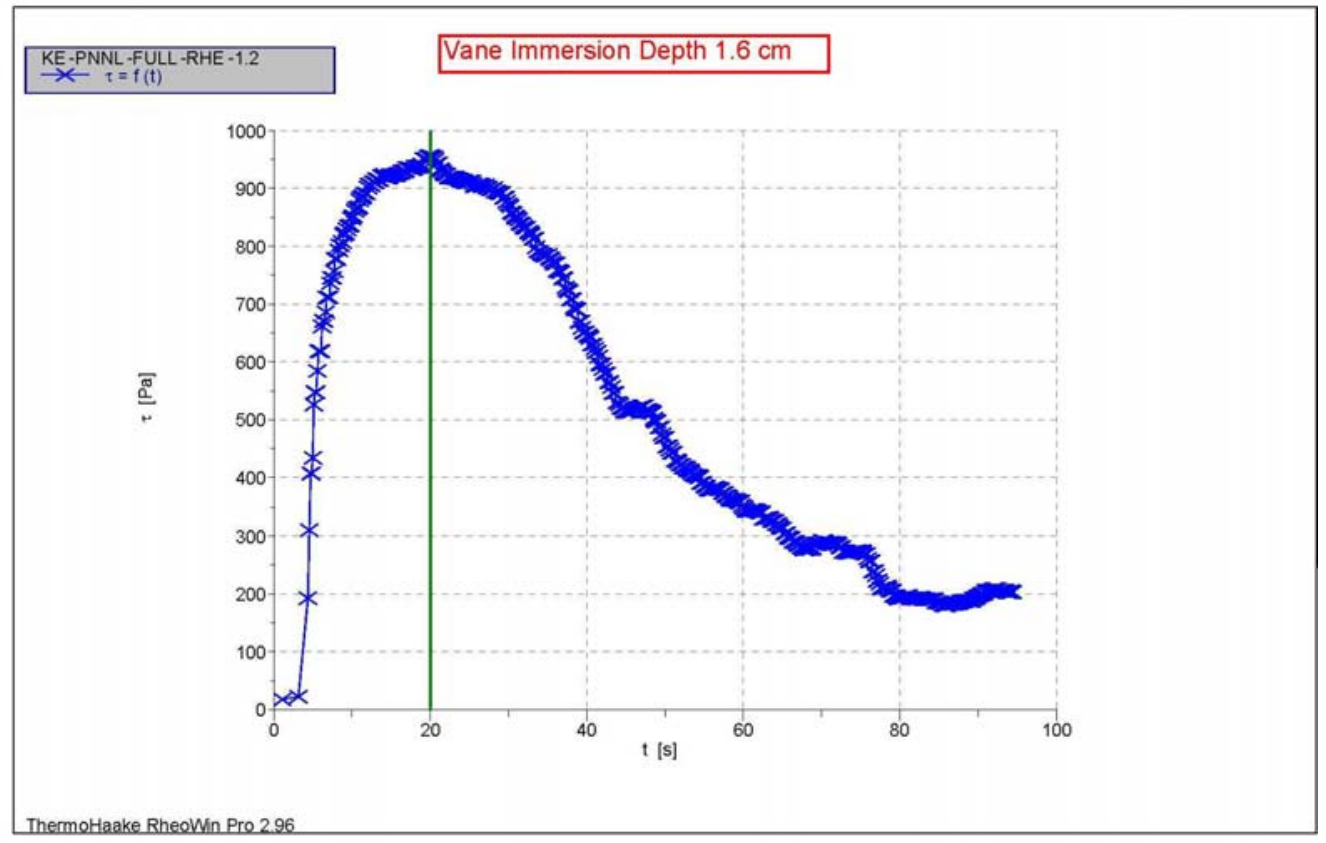

1: C:IProgram FilesIRheoWin IDatalTI37/Shear strength Mix 2IKE -PNNL-FULL -RHE -1.2.rwd

Company / Operator: PNNL / Carolyn Burns

Date / Time / Version: 12.02.2011 / 17:45:50 PM / RheoWin Pro 296

Substance / Sample no: KBasin TI037 / KE -PNNL-FULL-RHE -1.2

Curve discussion: Greatest value $\mathrm{t}[\mathrm{s}] 20.02 \tau[\mathrm{Pa}] 955.9$ 


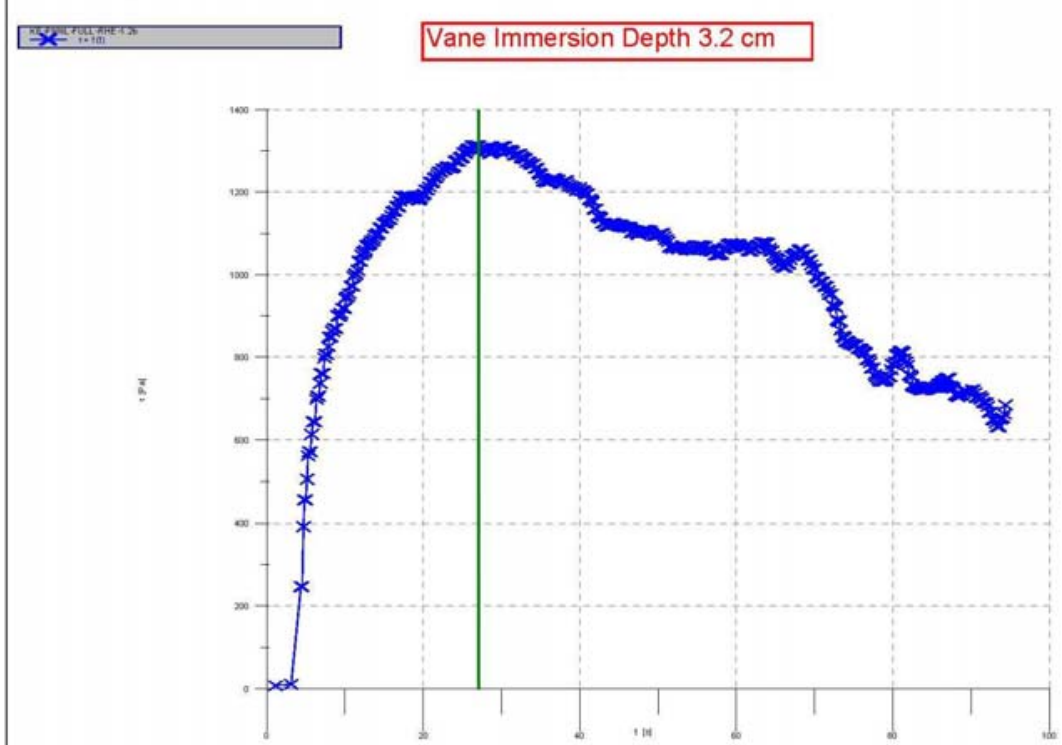

1: C:IProgram Files IRheoWin $\backslash$ DatalTI37IShear strength Mix 2IKE -PNNL -FULL -RHE -1.2b.rwd Company / Operator: PNNL / Carolyn Burns

Date / Time / Version: 12.02.2011 / 17:48:35 PM / RheoWin Pro 296

Substance / Sample no: KBasin TI037 / KE -PNNL -FULL -RHE -1.2b

Curve discussion: Greatest value $t[s] 27.08 \tau[\mathrm{Pa}] 1311$.

ThermoHaake RheoWin 2/14/2011/3:16 PM

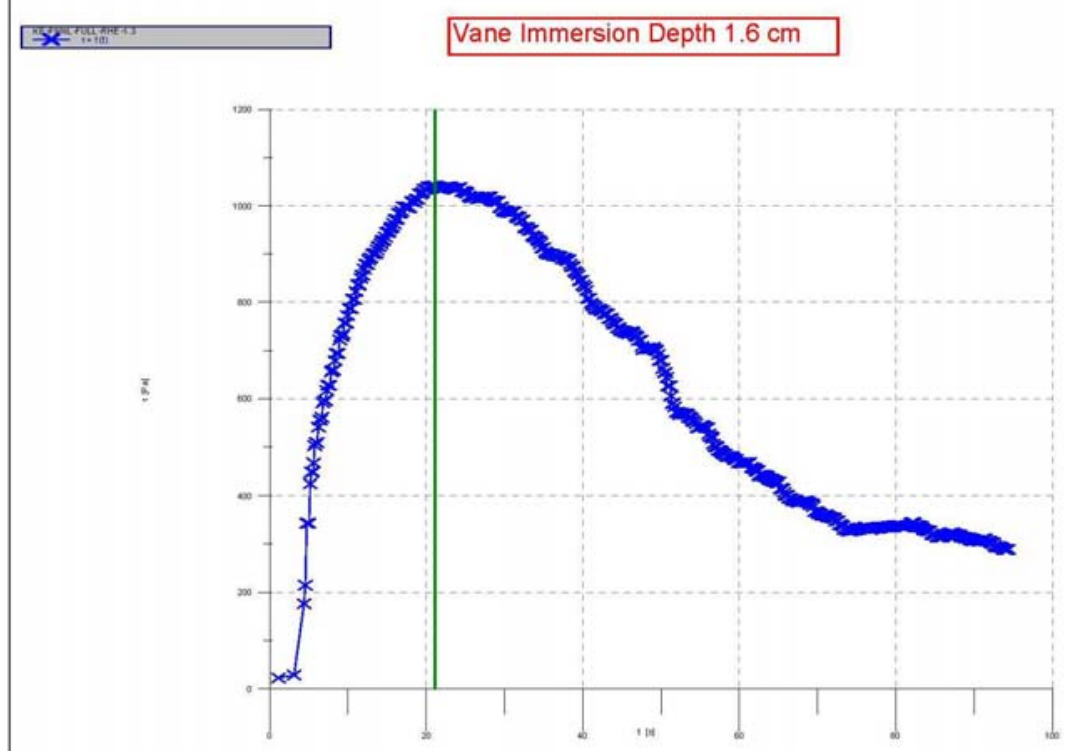

1: C:IProgram Files $\backslash$ RheoWin $\backslash$ DatalTI37|Shear strength Mix 2IKE -PNNL-FULL -RHE -1.3.rwd Company / Operator: PNNL / Carolyn Burns

Date / Time / Version: 12.02.2011 / 17:51:56 PM / RheoWin Pro 296

Substance / Sample no: KBasin TI037 / KE -PNNL-FULL-RHE -1.3

Curve discussion: Greatest value $\mathrm{t}[\mathrm{s}] 21.09 \tau[\mathrm{Pa}] 1041$. 
ThermoHaake RheoWin 2/14/2011/3:17 PM

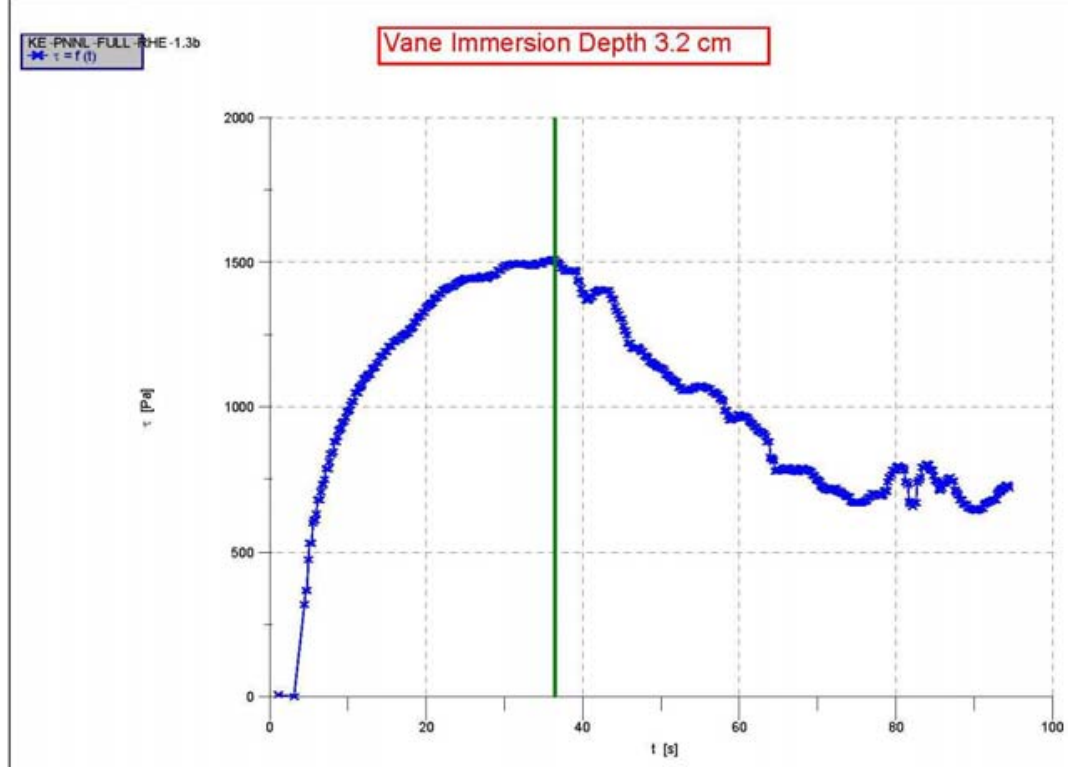

Thermothace Pheowin Pro 28

1: C:IProgram Files $\backslash R$ heoWin $\backslash$ DatalTI37IShear strength Mix 2IKE -PNNL-FULL -RHE -1.3b.rwd Company / Operator: PNNL / Carolyn Burns

Date / Time / Version: 12.02.2011 / 17:54:22 PM / RheoWin Pro 296

Substance / Sample no: KBasin TI037 / KE -PNNL -FULL -RHE -1.3b

Curve discussion: Greatest value $\mathrm{t}[\mathrm{s}] 36.45 \tau[\mathrm{Pa}] 1510$.

ThermoHaake RheoWin 2/14/2011/3:18 PM

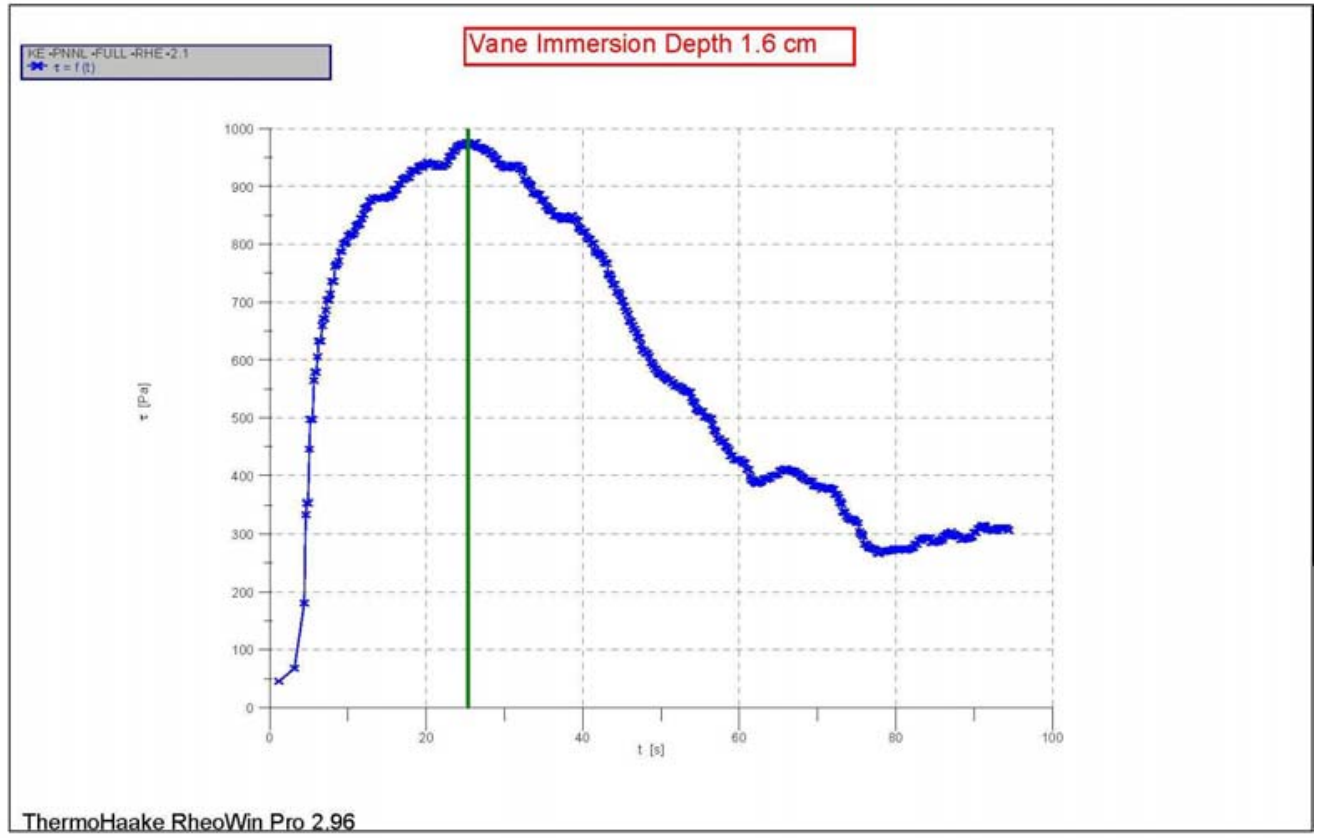

1: C: IProgram Files\RheoWin \DatalTI37\Shear strength Mix 2IKE -PNNL -FULL -RHE -2.1.rwd Company / Operator: PNNL / Carolyn Burns

Date / Time / Version: 12.02.2011 / 18:02:30 PM / RheoWin Pro 296

Substance / Sample no: KBasin TI037 / KE -PNNL-FULL-RHE -2.1

Curve discussion: Greatest value $\mathrm{t}[\mathrm{s}] 25.34 \tau[\mathrm{Pa}] 975.7$ 
ThermoHaake RheoWin 2/14/2011 / 3:19 PM

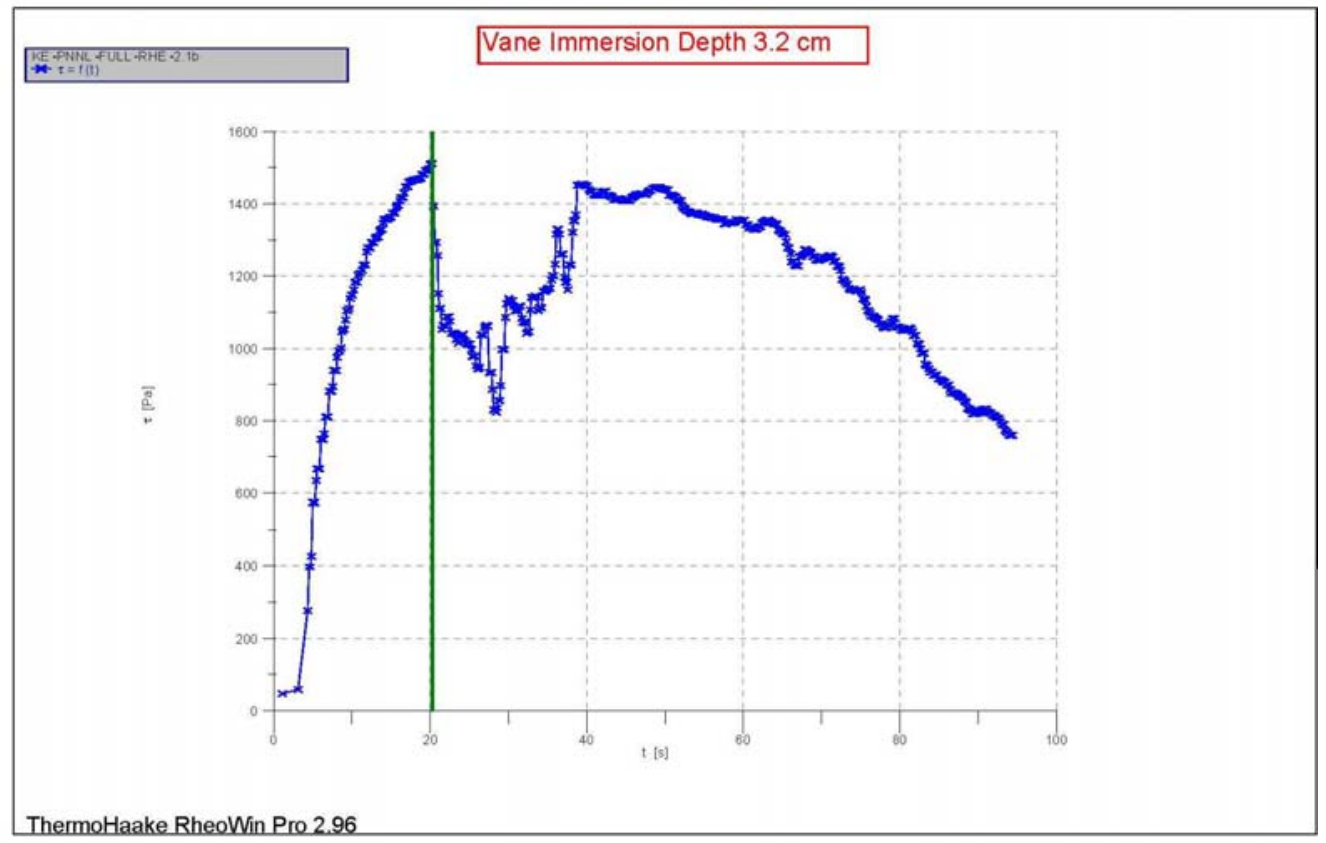

1: C:IProgram Files IRheoWin \DatalTI37IShear strength Mix 2IKE -PNNL -FULL -RHE -2.1b.rwd Company / Operator: PNNL / Carolyn Burns

Date / Time / Version: 12.02.2011 / 18:04:51 PM / RheoWin Pro 296

Substance / Sample no: KBasin T1037 / KE -PNNL-FULL -RHE -2.1b

Curve discussion: Greatest value $\mathrm{t}[\mathrm{s}] 20.28 \tau[\mathrm{Pa}] 1511$.

ThermoHaake RheoWin 2/14/2011/3:04 PM

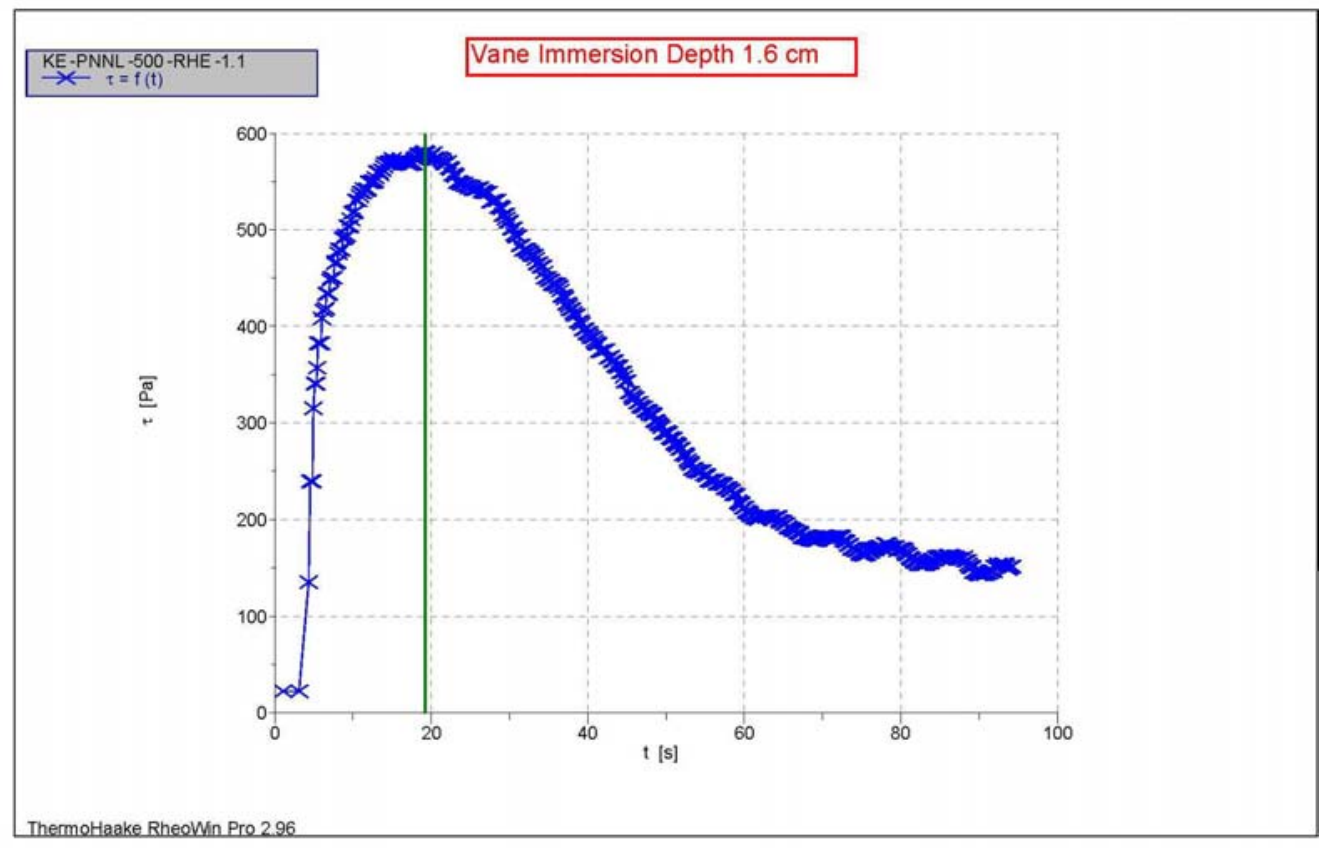

1: C:IProgram FilesIRheoWin $\backslash$ DatalTI37\Shear strength Mix 2IKE -PNNL -500-RHE -1.1.rwd Company / Operator: PNNL / Carolyn Burns

Date / Time / Version: 12.02.2011 / 18:13:26 PM / RheoWin Pro 296

Substance / Sample no: KBasin TI037 / KE -PNNL-500-RHE -1.1

Curve discussion: Greatest value $t[s] 19.22 \tau[\mathrm{Pa}] 580.5$ 
ThermoHaake RheoWin 2/14/2011 / 3:06 PM

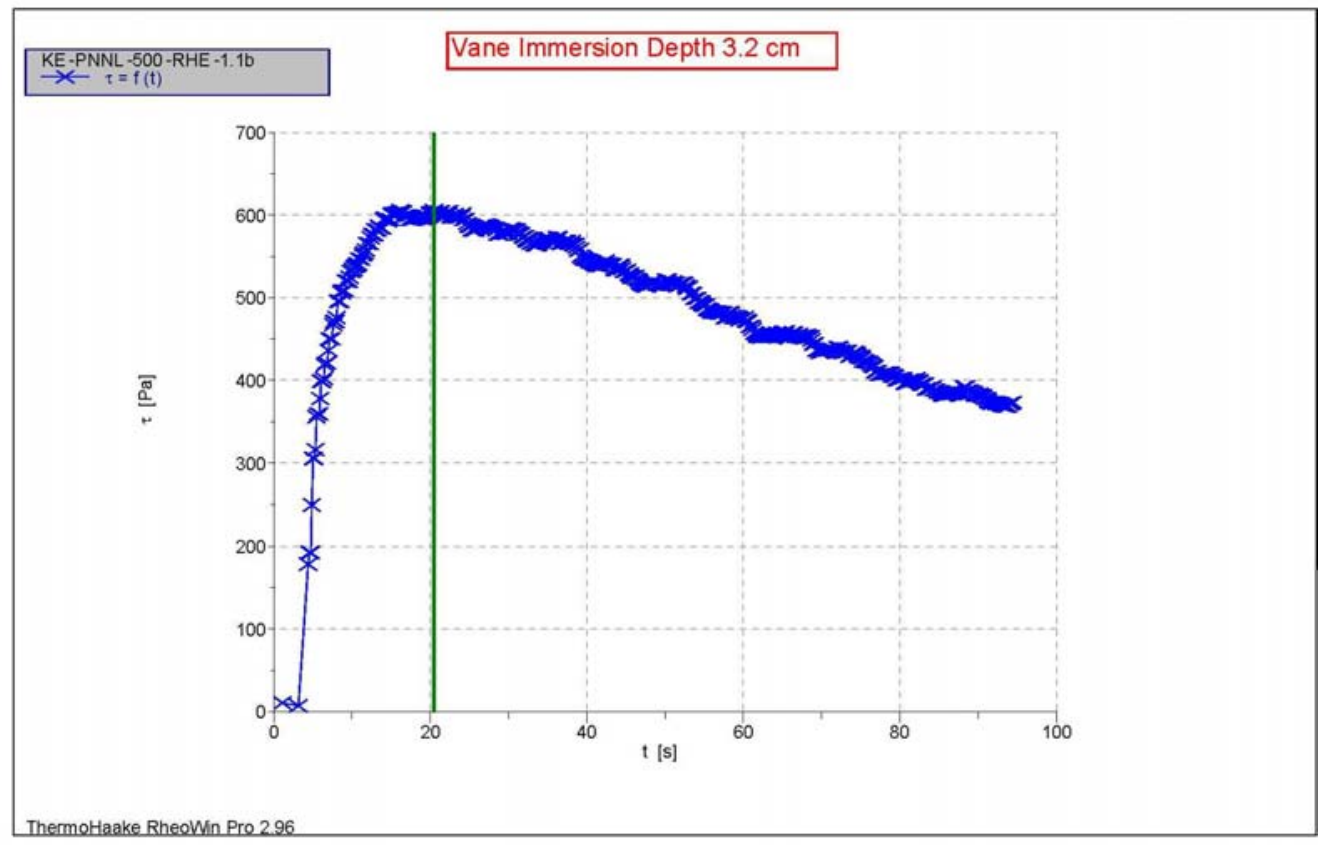

1: C:IProqram Files\RheoWin IDatalTI37\Shear strength Mix 2WKE -PNNL -500-RHE -1.1b.rwd Company / Operator: PNNL / Carolyn Burns

Date / Time / Version: 12.02.2011 / 18:15:46 PM / RheoWin Pro 296

Substance / Sample no: KBasin TI037 / KE -PNNL-500-RHE -1.1b

Curve discussion: Greatest value $\mathrm{t}[\mathrm{s}] 20.48 \tau[\mathrm{Pa}] 605.0$

ThermoHaake RheoWin 2/14/2011/3:08 PM

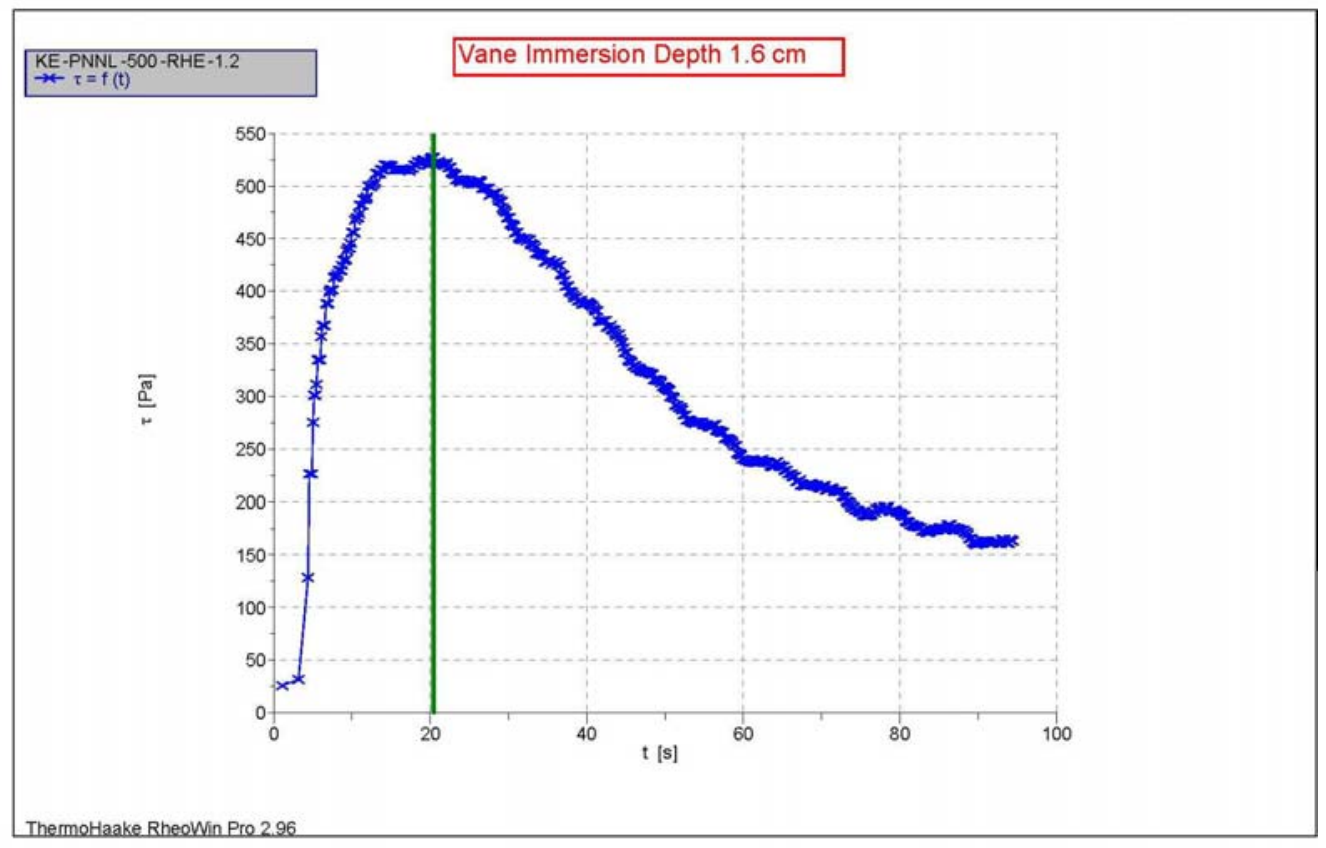

1: C:IProgram FilesIRheoWin $\backslash$ DatalTI37\Shear strength Mix 2IKE -PNNL -500-RHE -1.2.rwd

Company / Operator: PNNL / Carolyn Burns

Date / Time / Version: 12.02.2011 / 18:18:47 PM / RheoWin Pro 296

Substance / Sample no: KBasin TI037 / KE -PNNL-500-RHE -1.2

Curve discussion: Greatest value $\mathrm{t}[\mathrm{s}] 20.47 \tau[\mathrm{Pa}] 526.9$ 
ThermoHaake RheoWin 2/14/2011/3:09 PM

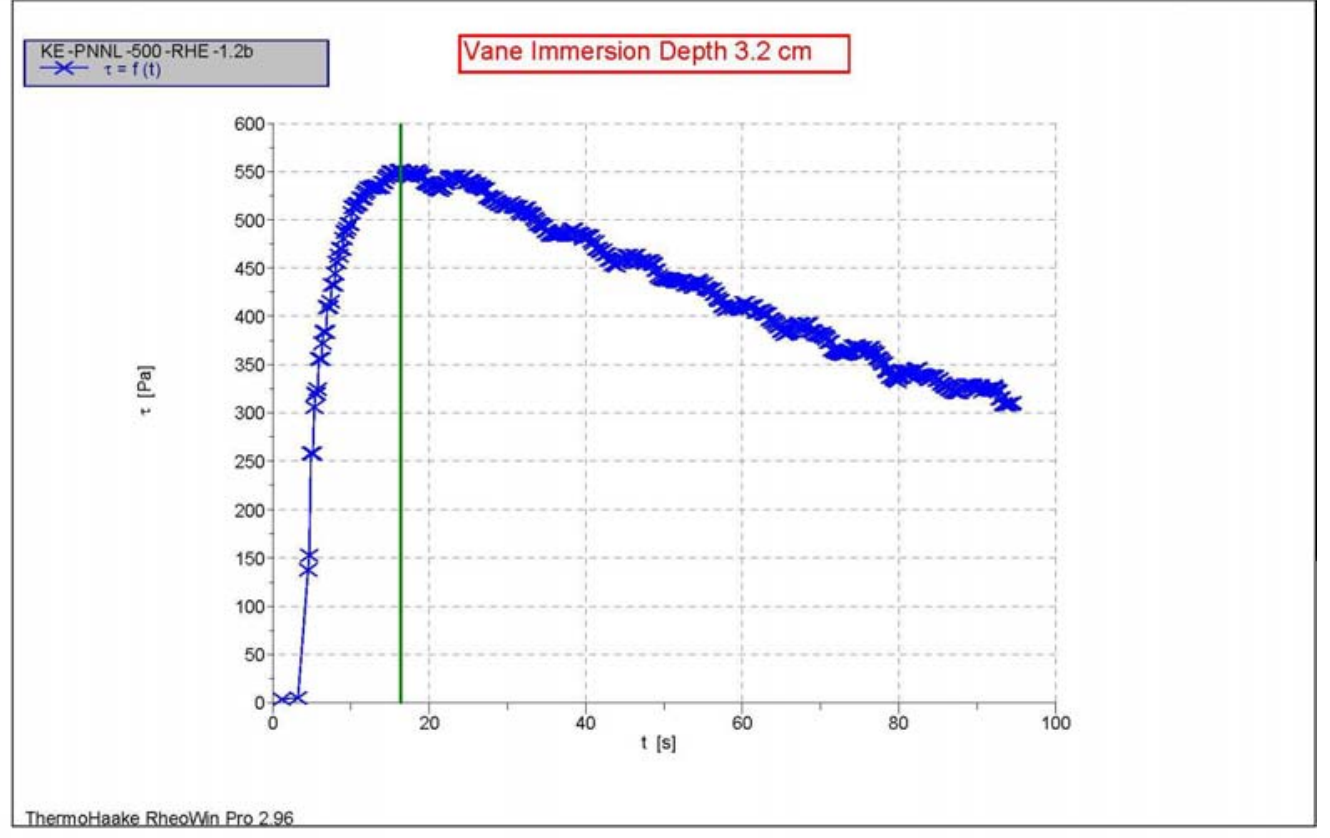

1: C:IProqram Files\RheoWin IDatalTI37\Shear strength Mix 2WKE -PNNL -500-RHE -1.2b.rwd Company / Operator: PNNL / Carolyn Burns

Date / Time / Version: 12.02.2011 / 18:21:07 PM / RheoWin Pro 296

Substance / Sample no: KBasin TI037 / KE -PNNL-500-RHE -1.2b

Curve discussion: Greatest value $\mathrm{t}[\mathrm{s}] 16.39 \tau[\mathrm{Pa}] 551.4$

ThermoHaake RheoWin 2/14/2011/3:09 PM

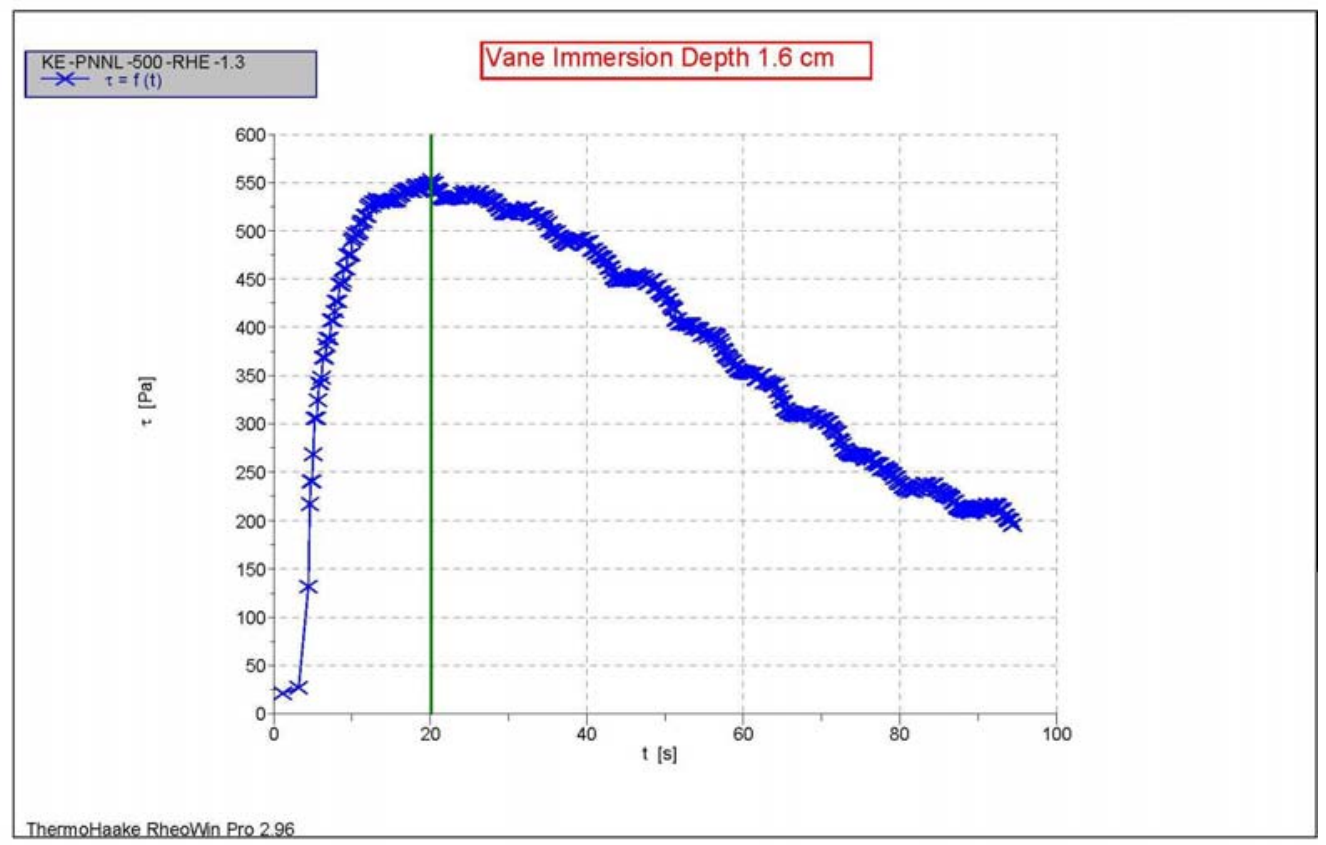

1: C:IProgram FilesIRheoWin $\backslash$ DatalTI37\Shear strength Mix 2IKE -PNNL -500-RHE -1.3.rwd Company / Operator: PNNL / Carolyn Burns

Date / Time / Version: 12.02.2011 / 18:23:50 PM / RheoWin Pro 296

Substance / Sample no: KBasin TI037 / KE -PNNL-500-RHE -1.3

Curve discussion: Greatest value $\mathrm{t}[\mathrm{s}] 20.12 \tau[\mathrm{Pa}] 552.5$ 
ThermoHaake RheoWin 2/14/2011/3:10 PM

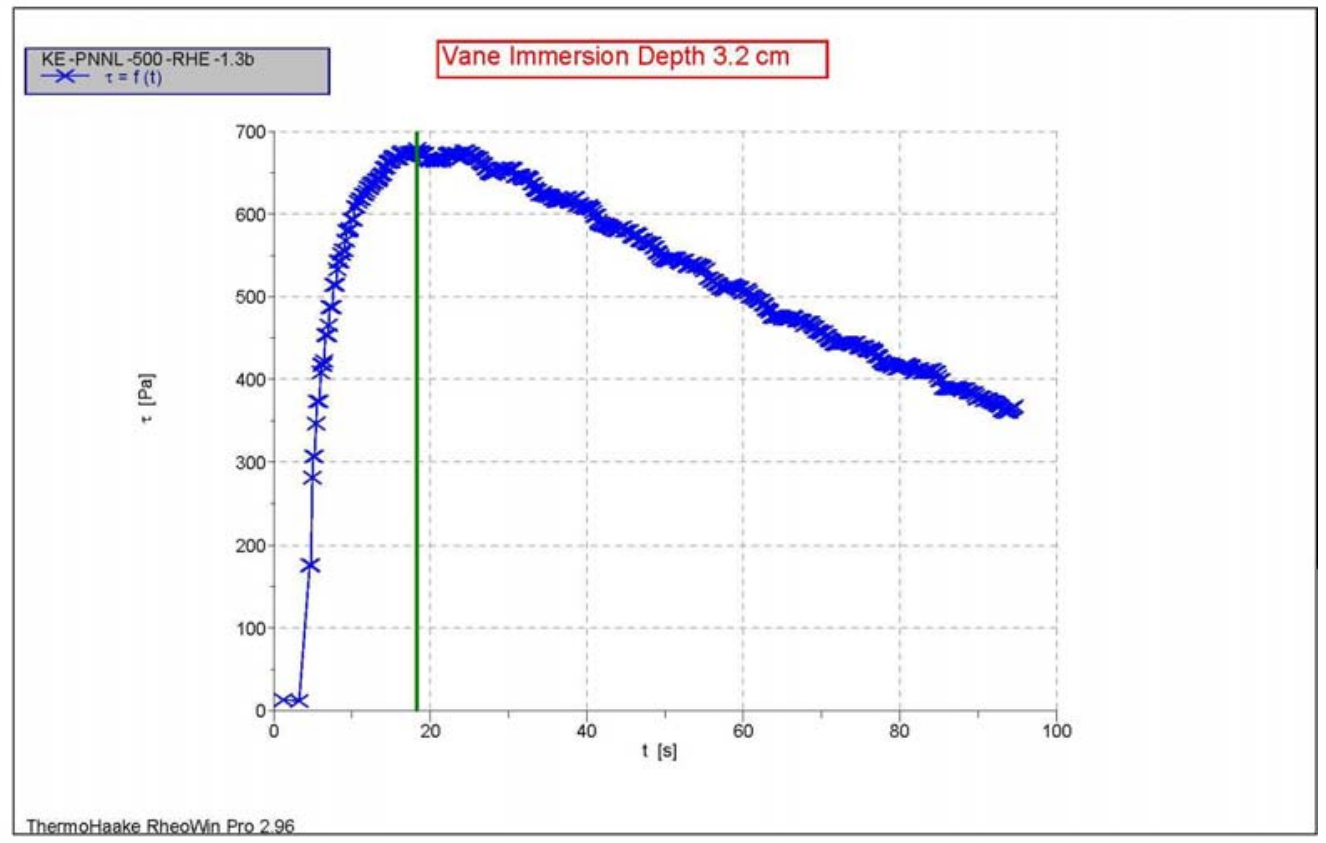

1: C:IProgram Files $|R h e o W i n \backslash D a t a| T \mid 37 \backslash$ Shear strength Mix 2IKE -PNNL -500 -RHE -1.3b.rwd Company / Operator: PNNL / Carolyn Burns

Date / Time / Version: 12.02.2011 / 18:26:04 PM / RheoWin Pro 296

Substance / Sample no: KBasin TI037 / KE -PNNL-500-RHE -1.3b

Curve discussion: Greatest value $\mathrm{t}[\mathrm{s}] 18.30 \tau[\mathrm{Pa}] 678.4$

ThermoHaake RheoWin 2/14/2011/3:11 PM

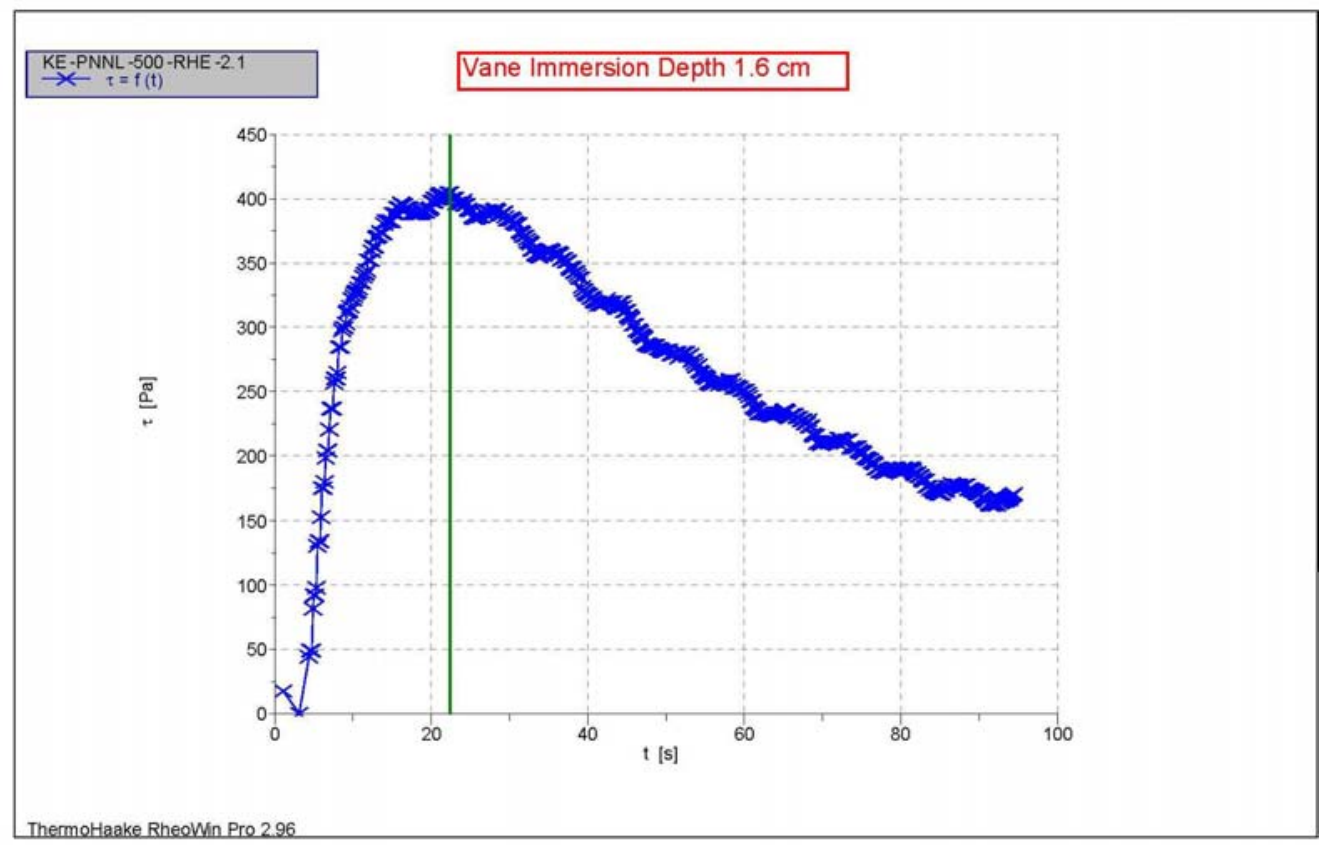

1: C:IProgram FilesIRheoWin $\backslash$ DatalTI37\Shear strength Mix 2IKE -PNNL -500-RHE -2.1.rwd Company / Operator: PNNL / Carolyn Burns

Date / Time / Version: 12.02.2011 / 18:33:59 PM / RheoWin Pro 296

Substance / Sample no: KBasin TI037 / KE -PNNL-500-RHE -2.1

Curve discussion: Greatest value $\mathrm{t}[\mathrm{s}] 22.44 \tau[\mathrm{Pa}] 404.5$ 


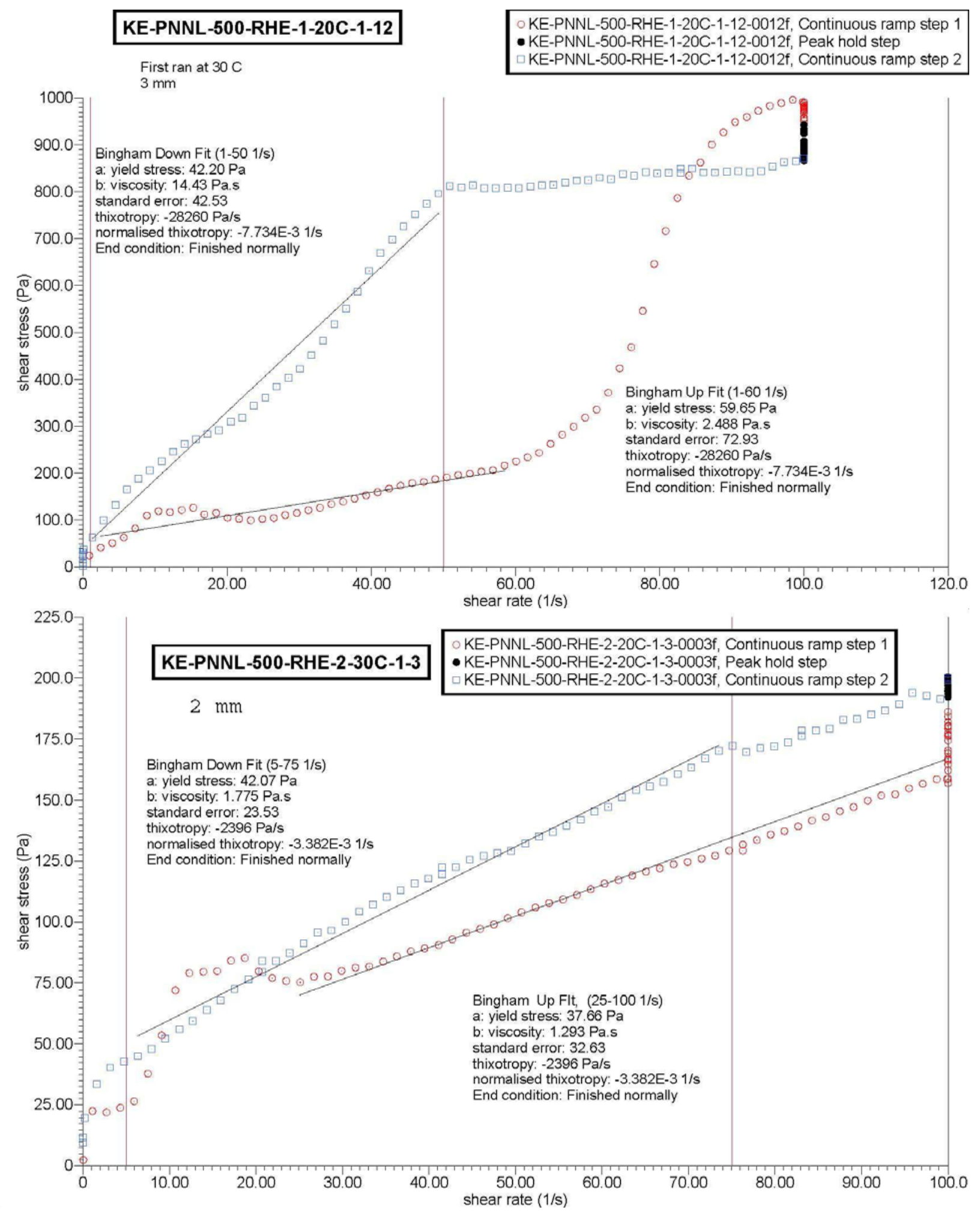




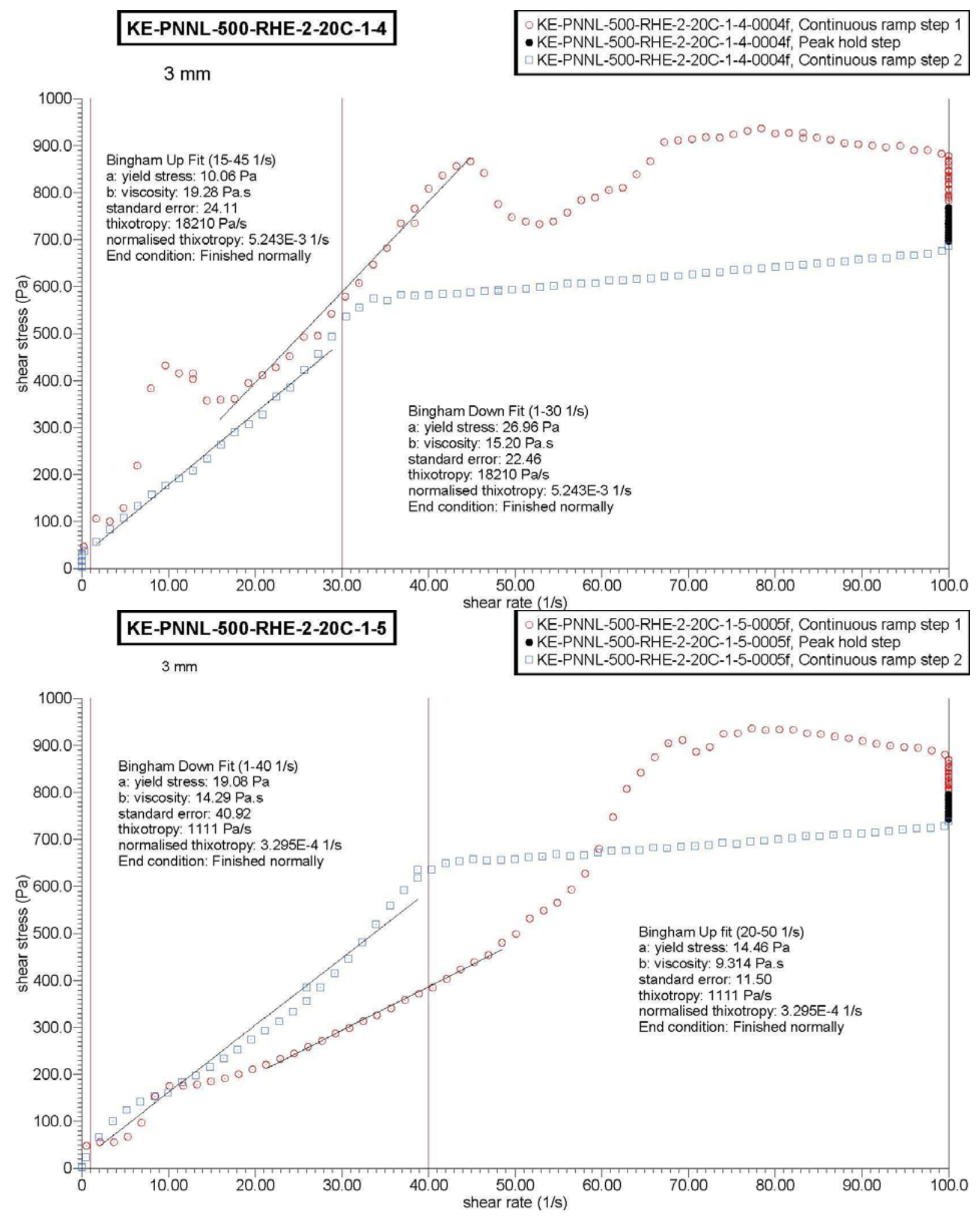




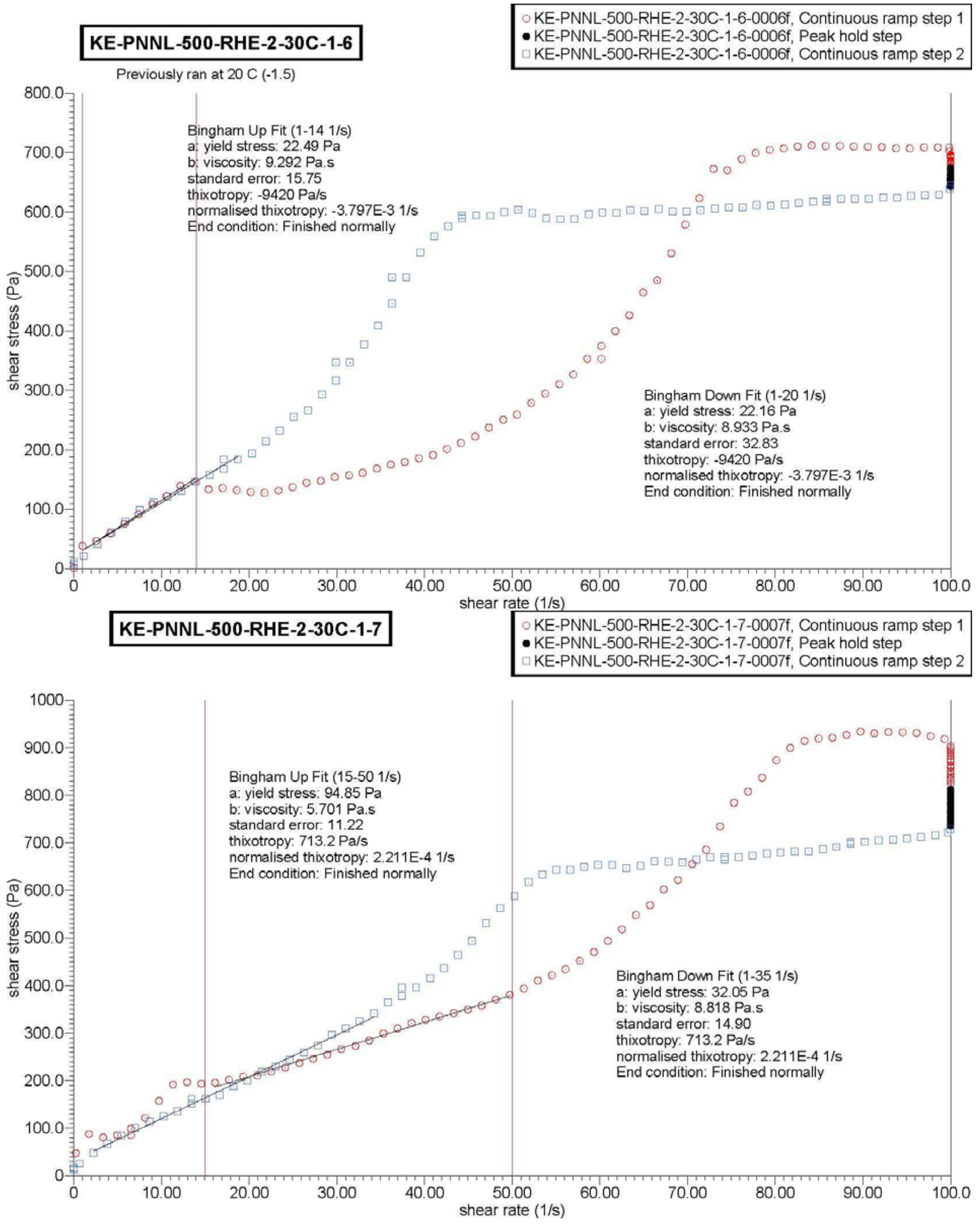


KE-PNNL-500-RHE-2-20C-1-8

ran at $30 \mathrm{C}$ first (1.7)

$3 \mathrm{~mm}$
KE-PNNL -500-RHE-2-20C-1-8-0008f, Continuous ramp step 1

- KE-PNNL-500-RHE-2-20C-1-8-0008f, Peak hold step

KE-PNNL-500-RHE-2-20C-1-8-0008f, Continuous ramp step 2

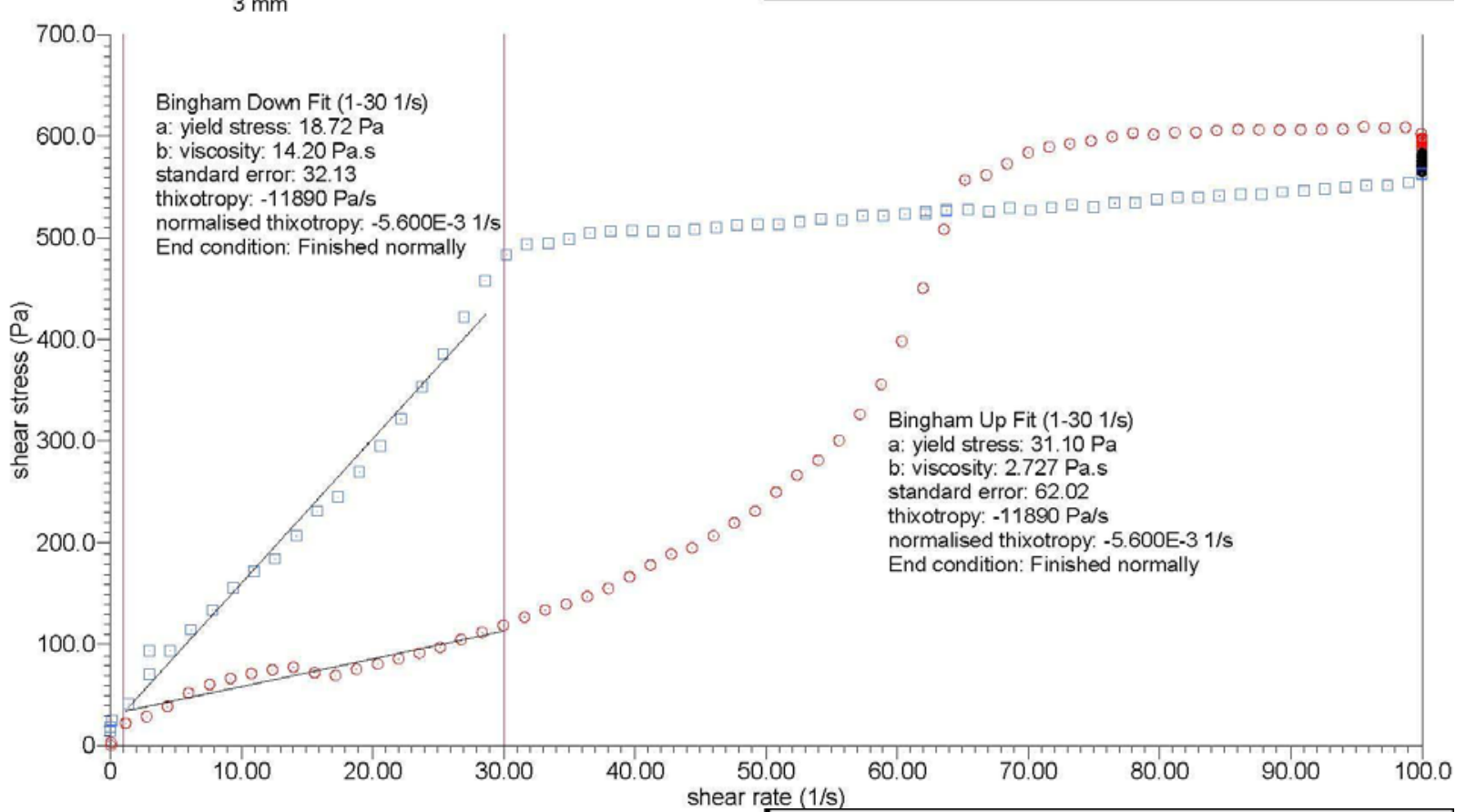

KE-PNNL-500-RHE-1-20C-1-9

KE-PNNL-500-RHE-1-20C-1-9-0009f, Continuous ramp step 1 - KE-PNNL-500-RHE-1-20C-1-9-0009f, Peak hold step

KE-PNNL-500-RHE-1-20C-1-9-0009f, Continuous ramp step 2

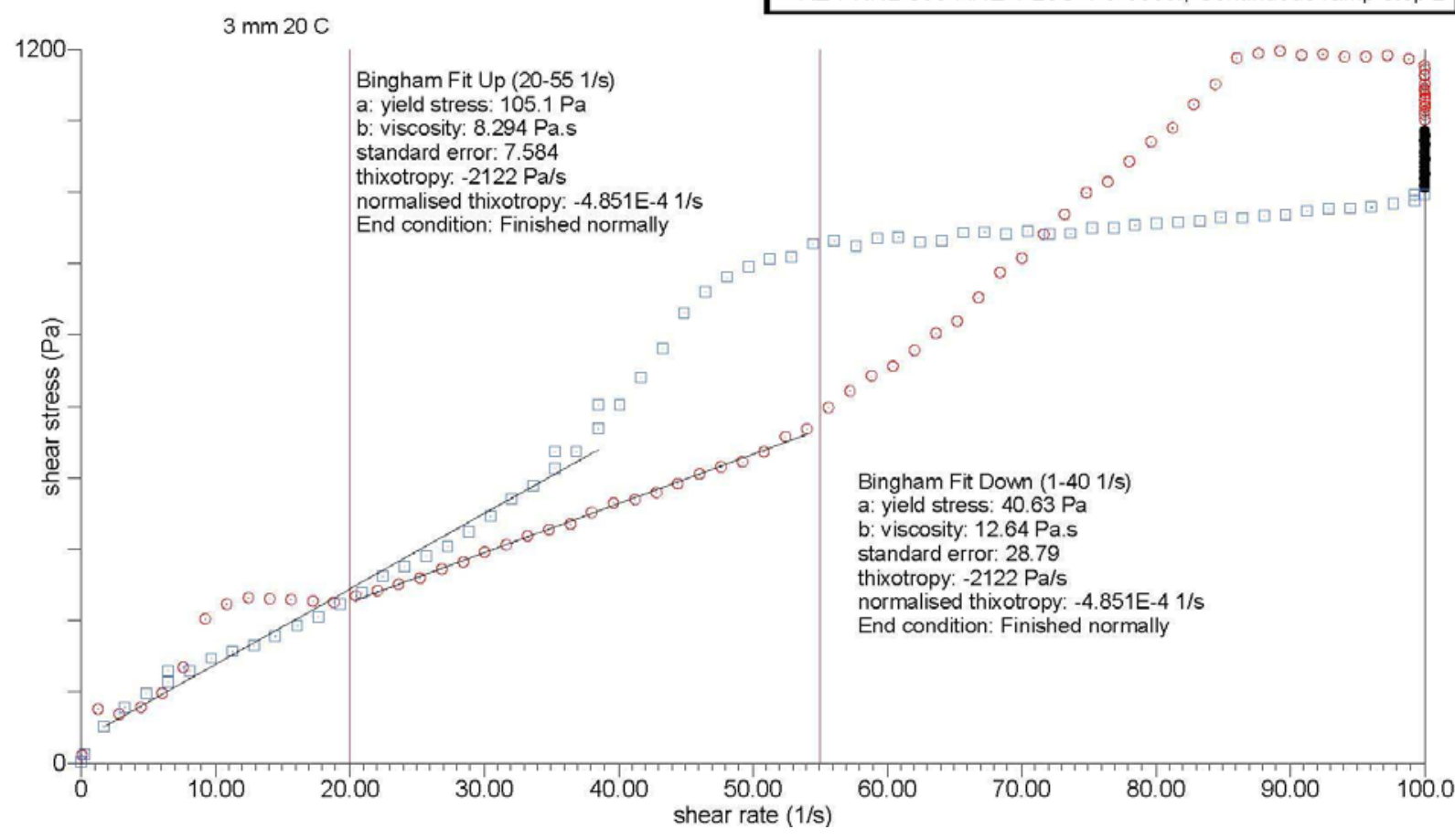

C. 40 


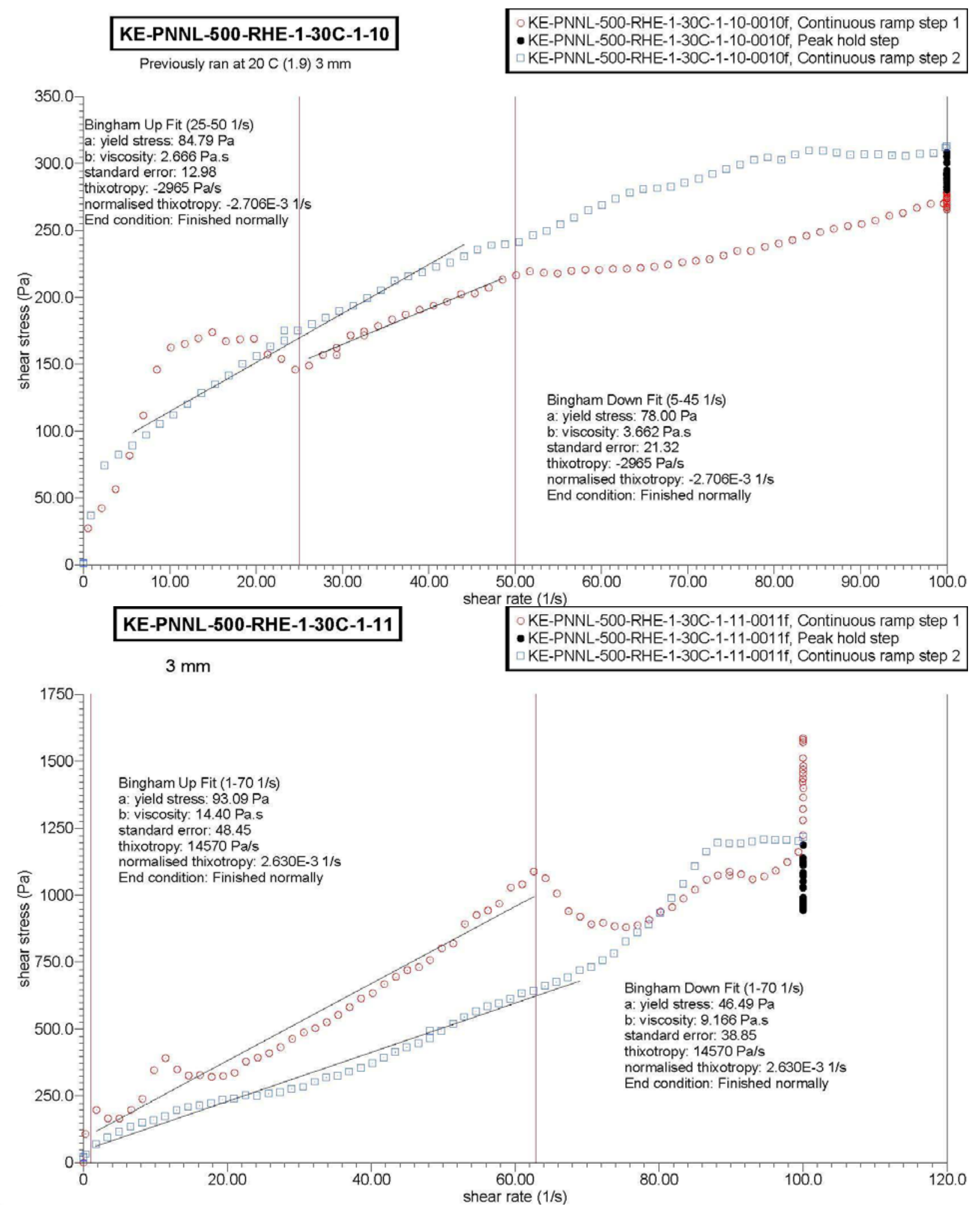



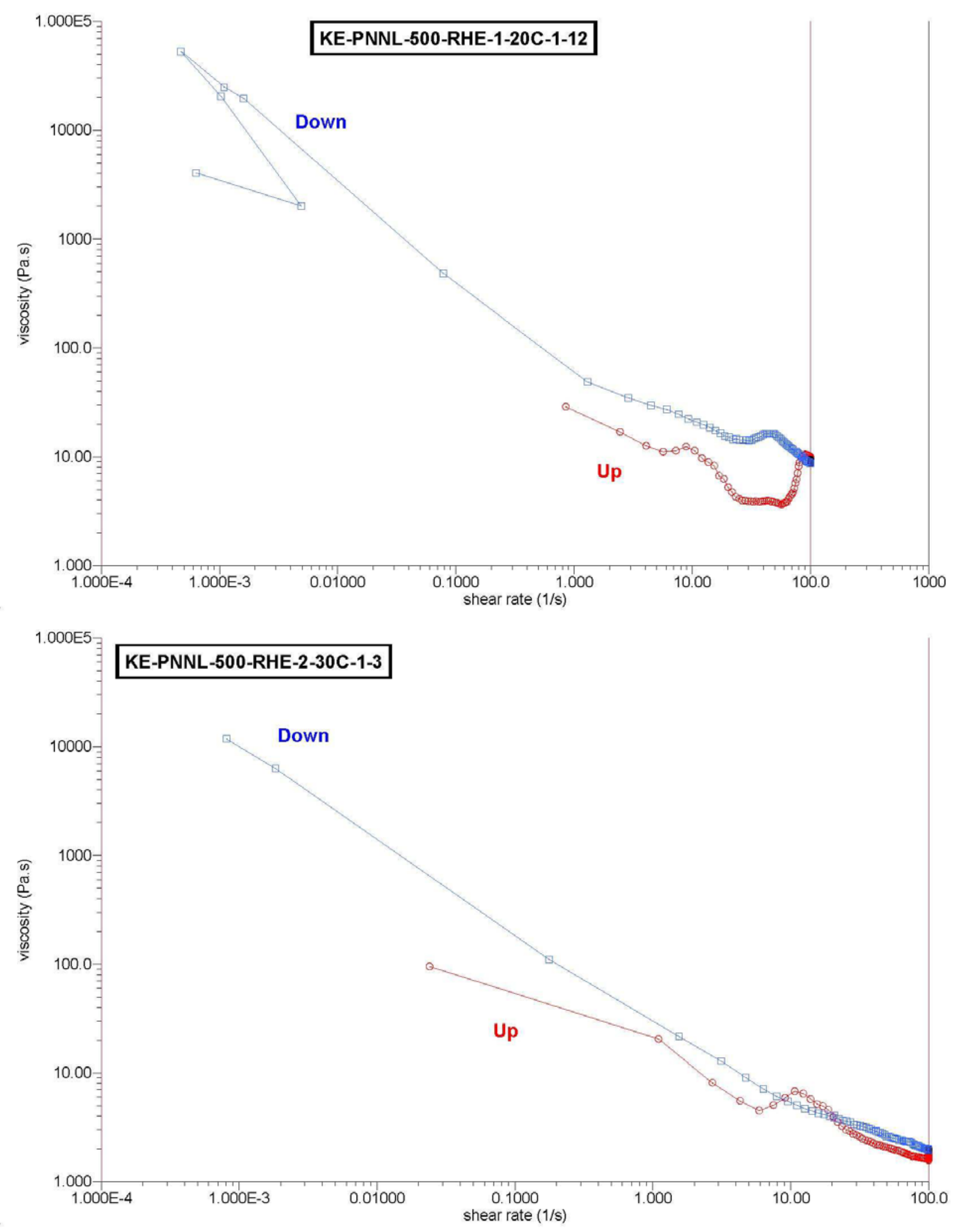

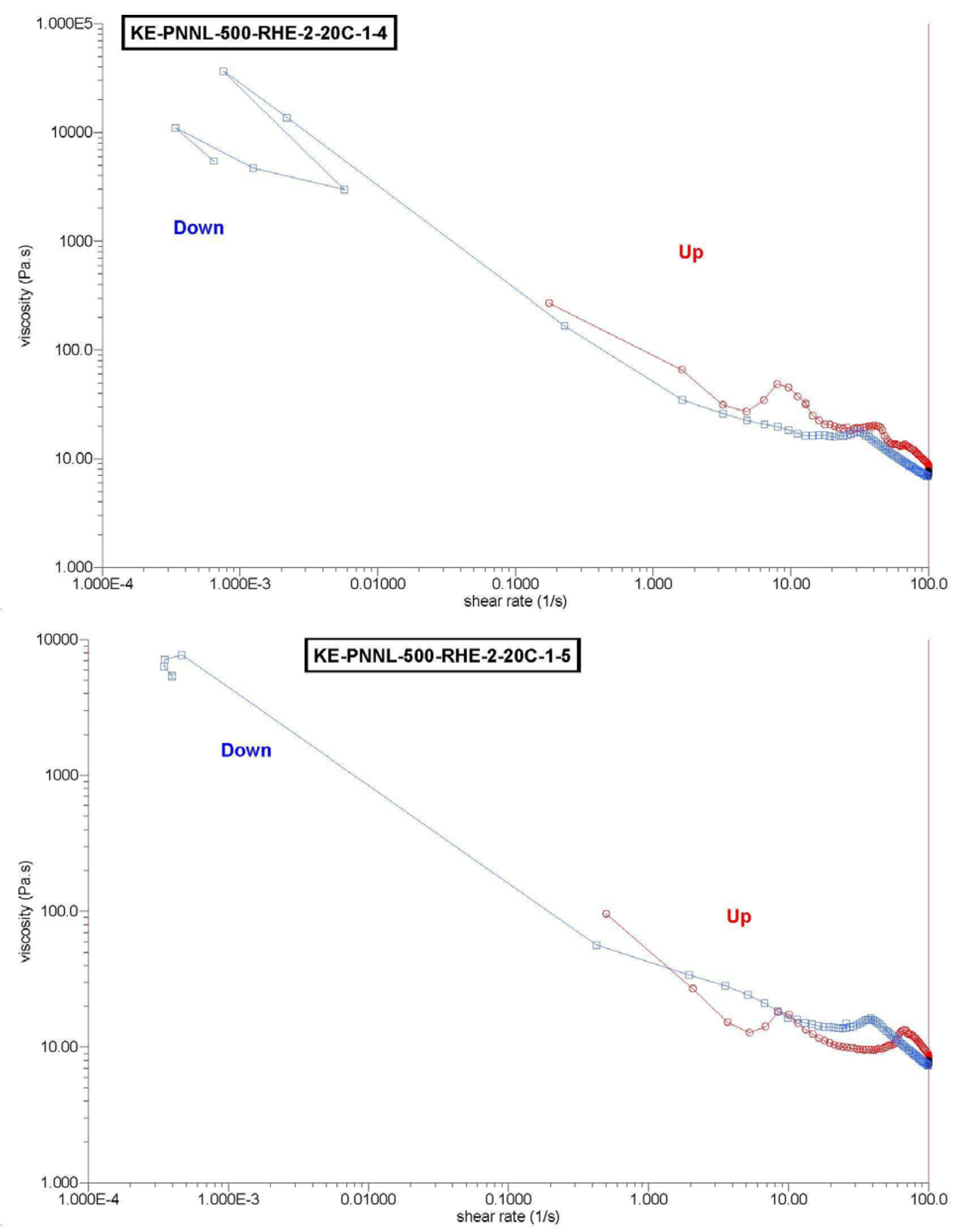

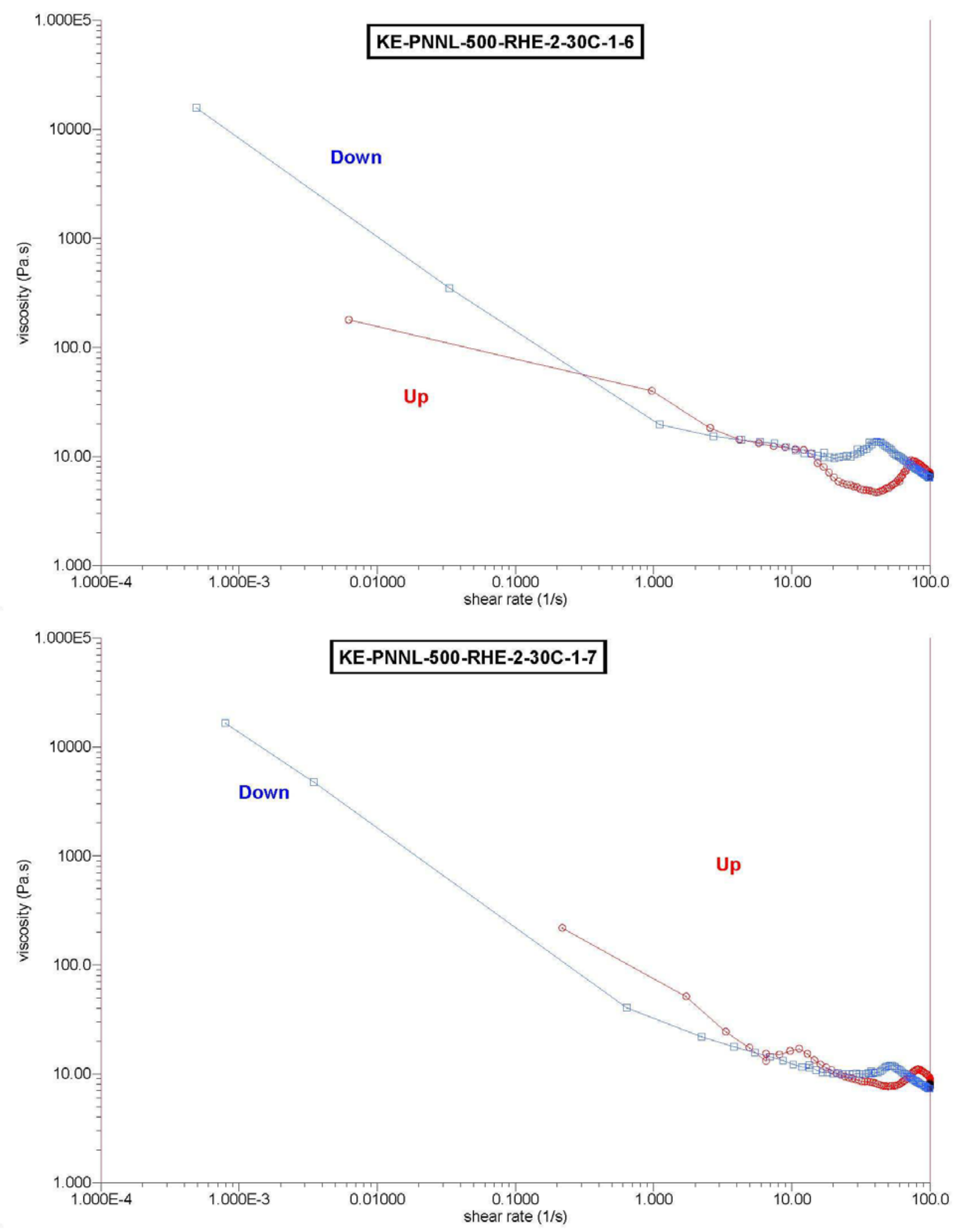

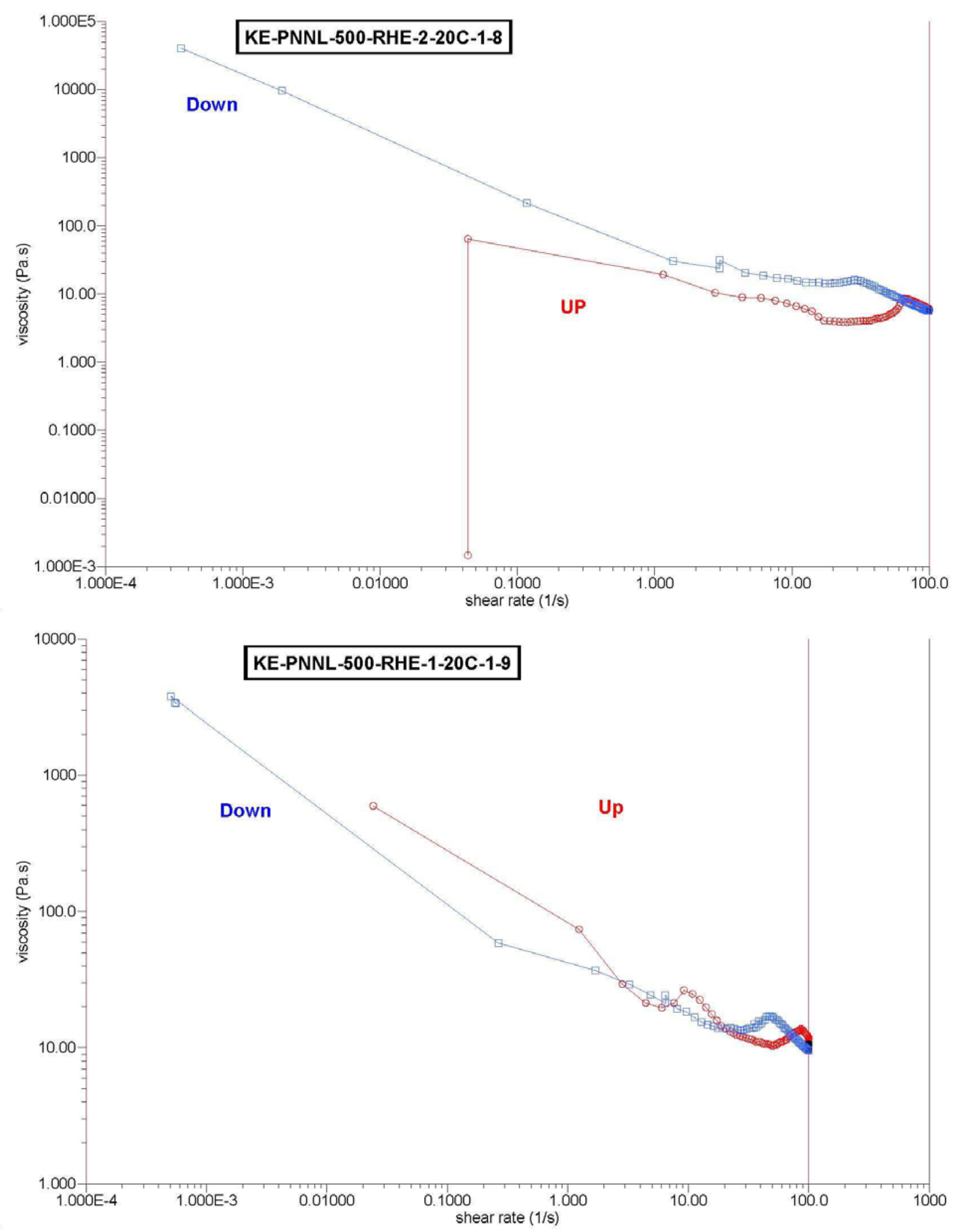

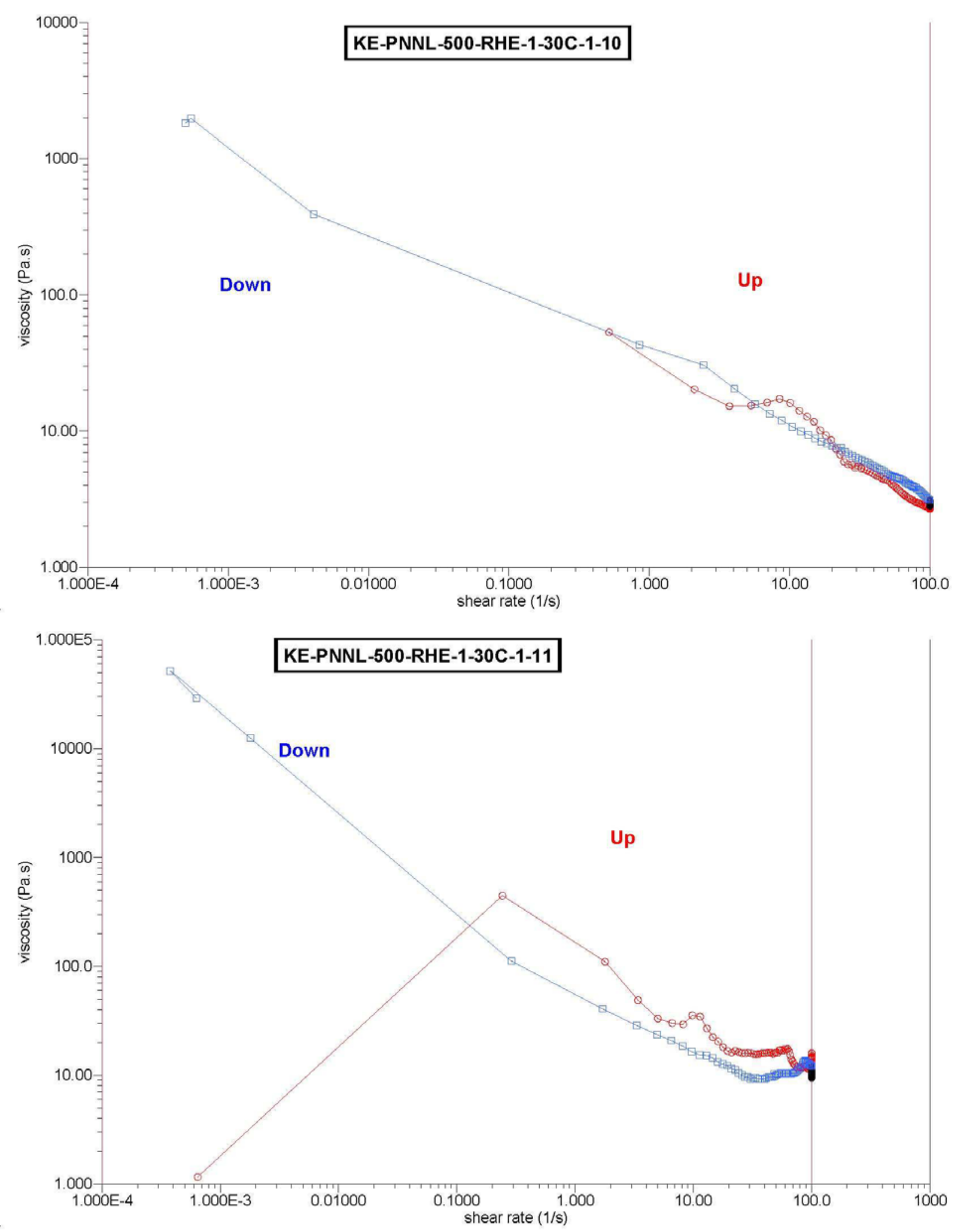


\section{Distribution}

No. of

Copies

9 CH2M Hill Plateau Remediation Company

R.B. Baker

D.A. Burbank

J.D. Criddle

D.W. Hamilton

J.O. Honeyman

M.E. Johnson

W.W. Rutherford

J.P. Sloughter

STP Project File
A3-06

A0-26

A0-26

A3-06

A3-06

A $0-26$

A3-06

A3-06

R1-29
No. of

Copies

11 Pacific Northwest National Laboratory

C.A. Burns

P7-25

C.D. Carlson

$\mathrm{P} 7-25$

R.C. Daniel

P7-22

C.H. Delegard

$\mathrm{P} 7-25$

S.K. Fiskum

$\mathrm{P} 7-25$

P.A. Gauglitz

K7-15

M Luna

J4-02

Y Onishi

K7-15

A.J. Schmidt

$\mathrm{P} 8-60$

R.W. Shimskey

P7-27

Information Release (pdf)

53451 Project File

K3-52

Dist. 1 


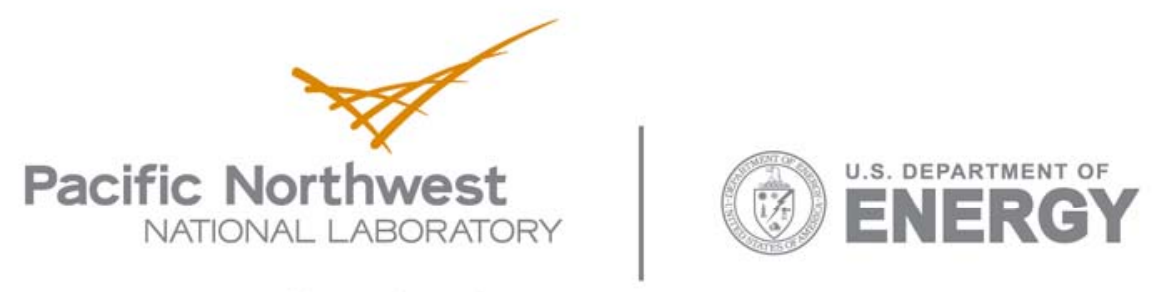

902 Battelle Boulevard

P.O. Box 999

Richland, WA 99352

1-888-375-PNNL (7665)

www.pnl.gov 